\title{
CHINA DREAMS
}

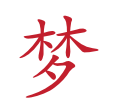

\author{
EDITED BY \\ Jane Golley, Linda Jaivin \\ Ben Hillman, wiтн Sharon Strange
}

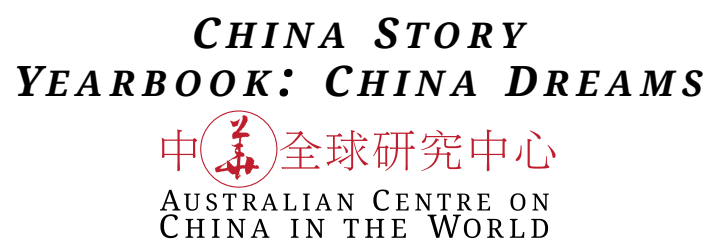

Australian 
Published by ANU Press

The Australian National University

Acton ACT 2601, Australia

Email: anupress@anu.edu.au

Available to download for free at press.anu.edu.au

ISBN (print): 9781760463731

ISBN (online): 9781760463748

WorldCat (print): 1145684061

WorldCat (online): 1145684091

DOI: $10.22459 / C S Y .2020$

This title is published under a Creative Commons Attribution-NonCommercialNoDerivatives 4.0 International (CC BY-NC-ND 4.0).

\section{(9) $(\Theta \Theta \Theta$}

The full licence terms are available at creativecommons.org/licenses/by-nc-nd/4.0/ legalcode

Design concept by Markuz Wernli; 'Power' cover design and chapter openers by CRE8IVE Typesetting by Chin-Jie Melodie Liu and Sharon Strange; copyediting by Jan Borrie Printed by Union Offset Printers, Canberra, Australia

The Australian Centre on China in the World is an initiative of the Commonwealth Government of Australia and The Australian National University

This edition (c) 2020 ANU Press 
揭蓄美

秘，梦

错多、

综元泡

时 视 影

事角、

，呈凌

为 现 云

中 政壮

国 经志

在文与

全化梦于

球与魏此

日与于,

渐文中令

隆文外中

盛社大国

势会 地 故

力之上事

与一相年

影脉吸鉴

响相相:

提连斥梦

供。之

解本画钩

惑年卷沉

之鉴; 是

匙以并年

。浅一重

显 如大

易 既 事

懂往件

的兼,

笔 容 展

触 并 示
民因续倡压学庆2

伟辑压中碎运中

大婴维国。动华

复儿吾公 2 三人

兴事尔民 0 十民

之件族应 1 周 共

梦, 群在 9 年和

对拓、国年整国

中展日际, 正成各年

国南益场几民立领中

与极恶合多主七风国

世与化 $=$ 旧与十骚恰

界称中维 言周。逢

民霸美护梦论年五几

众太关国自弘四个

而空系家重由扬运划

言的成荣回在革动时

为雄为誉, 凌命百代

何心媒り粉晨与年意

种亦体。墨的国祭义

图甚焦香登梦家重的

景唅点港场乡富温周

, 尘。暴。中强爱年

一上人力习被之国纪

时。工抗近政梦情念

庙习智争平府。怀日

堂近能风主的是与,

江平的起席安年文新

湖脑突云权定亦化旧

與海飞涌倾团距革

情中猛、天结 1 新中

四的进新下之 9 之国

起中与疆, 梦8 梦梦

。华 基 持 并 碾 9 ; 多 


\section{Contents}

INTRODUCTION

viii - Dream On · JANE GOLLEY, BEN HILLMAN, and LINDA JAIVIN

xviii $\cdot$ Acknowledgements

xviii - The Cover Image

\begin{tabular}{c|l} 
& FORUM - ILLUSIONS AND TRANSFORMATIONS: THE MANY MEANINGS OF MENG 萝 \\
5. & From the Land of Illusion to the Paradise of Truth · ANNIE LUMAN REN \\
$11 \cdot$ & Zhuangzi and His Butterfly Dream: The Etymology of Meng 夢· JINGJING CHEN
\end{tabular}

CHAPTER 1

19. A Dream of Perpetual Rule · GLORIA DAVIES

\begin{tabular}{l|l} 
37. & FORUM - ENFORCING THE DREAM \\
43. & Xi Jinping's War on 'Black and Evil' • BEN HILLMAN \\
The Changing 'Dream' in the Classroom: Literary Chinese Textbooks in the PRC \\
- ESTHER SUNKYUNG KLEIN and VICTOR FONG
\end{tabular}

CHAPTER 2

$51 \cdot$ Hong Kong's Reckoning · ANTONY DAPIRAN

\begin{tabular}{l|l} 
73. & FORUM - U NDER O BSERVATION \\
$79 \cdot$ & Legalism and the Social Credit System • SAMUEL J. PARSONS \\
'Evil Cults' and Holy Writ · BENJAMIN PENNY
\end{tabular}

CHAPTER 3

87 Meridians of Influence in a Nervous World

- BRENDAN TAYLOR and RICHARD RIGBY

\begin{tabular}{l|l}
$105 \cdot$ & FORUM $\cdot$ PROJECTING THE DREAM \\
$111 \cdot$ & Dreams in Space · ADAM NI \\
Antarctic Ambitions: Cold Power • BEYONGO MUKETE DYNAMIC
\end{tabular}

CHAPTER 4

119 Conscious Decoupling: The Technology Security Dilemma

- DARREN LIM and VICTOR FERGUSON

\begin{tabular}{l|l}
$137 \cdot$ & FORUM $\cdot$ CONSCIOUS COUPLING! \\
Queer Dreams · JAMIE ZHAO
\end{tabular} 
143. AI Dreams and Authoritarian Nightmares - OLIVIA SHEN
FORUM • LIFE AND DEATH
161 • Dream Babies · JANE BROPHY
167 · Recurring Nightmare: The Plague Visits Beijing
- JANE BROPHY

\section{CHAPTER 6}

175 - Urbanising Tibet: Aspirations, Illusions, and Nightmares

- GERALD ROCHE, JAMES LEIBOLD, and BEN HILLMAN

\section{\begin{tabular}{l|l}
$191 \cdot \mid \begin{array}{l}\text { FORUM • FORGOTTEN HISTORIES } \\
\text { 'Prairie Mothers' and Shanghai Orphans • UCHRALT OTEDE }\end{array}$
\end{tabular}}

\section{CHAPTER 7}

199 - Schemes, Dreams, and Nightmares: China's Paradox(es) of Trust

- GERRY GROOT

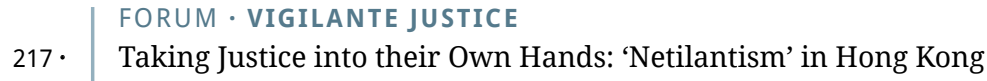
- LENNON YAO-CHUNG CHANG

\section{CHAPTER 8}

223 Hong Kong and the Tiananmen Playbook · LOUISA LIM and GRAEME SMITH

\footnotetext{
FORUM • SHARING THE DREAM?

241 • South Korea and the 'China Effect' • HYUNG-GEUN KIM

247 - Taiwanese Dreams: Security, Sovereignity, and the Space to be Seen

- CHIUNG-CHIU HUANG
}

\section{CHAPTER 9}

255 - Campus Conundrums: Clashes and Collaborations

- JANE GOLLEY, PAUL HARRIS, and JAMES LAURENCESON

\begin{tabular}{l|l}
$269 \cdot$ & NOTES \\
$299 \cdot$ & CONTRIBUTORS
\end{tabular}

305 .

PREVIOUS CHINA STORY YEARBOOKS 


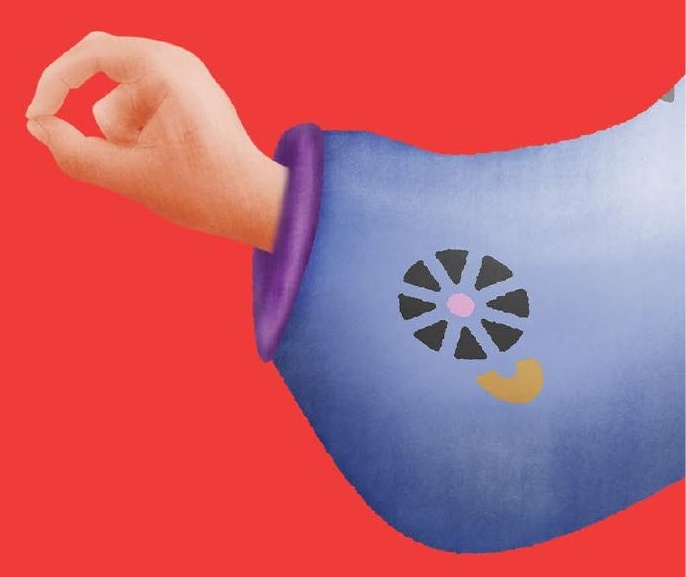




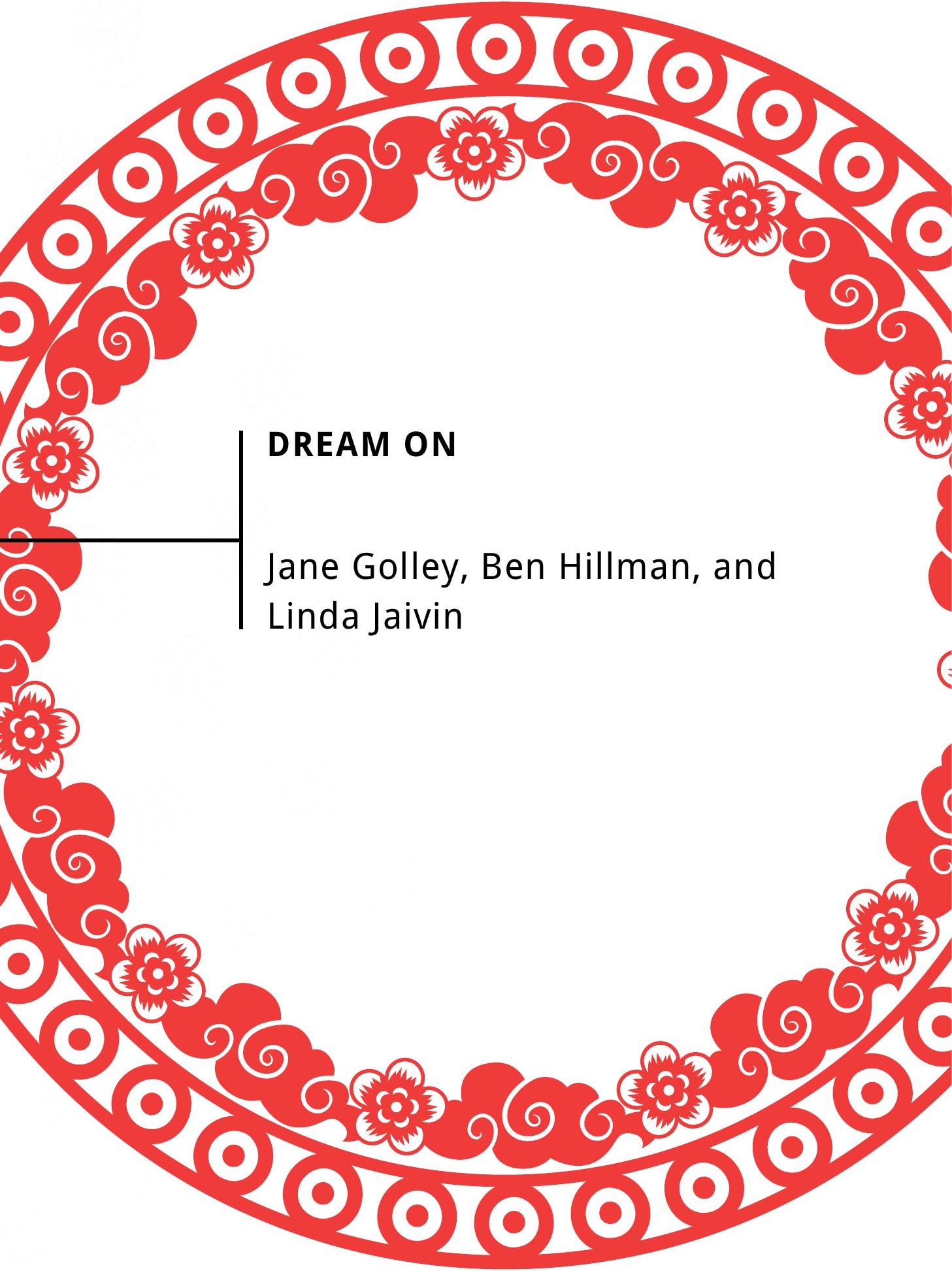




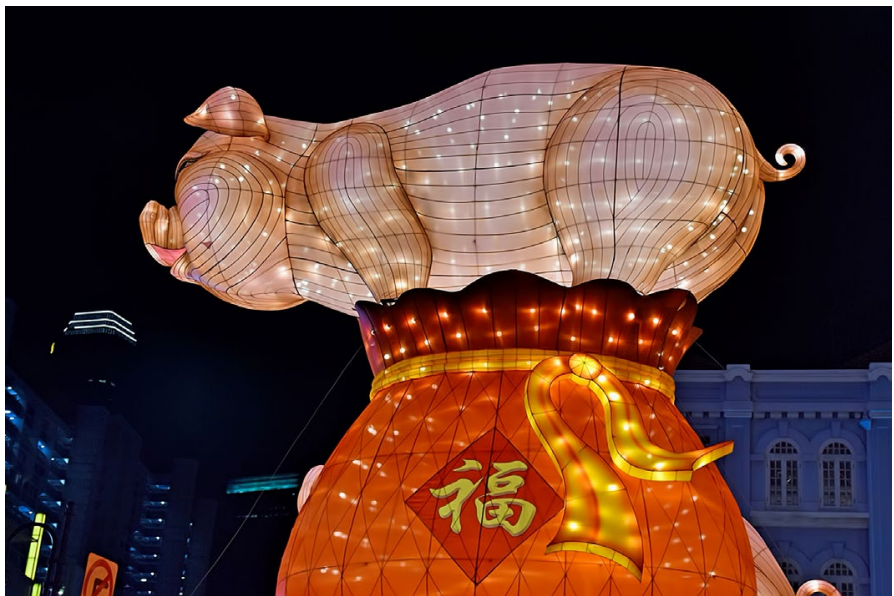

A pig lantern lights up the streets in Singapore for Chinese New Year celebrations in 2019 Source: Choo Yut Shing, Flickr

According to legend, the Jade Emperor called all twelve celestial animals to his palace to assign them their place in the zodiac. The Pig, a lazy if intelligent creature, was still in dreamland when the other eleven turned up to claim their places. He ended up last. And so 2019, the eventful Year of the Pig (coincidentally also marked by swine fever and a severe pork supply shortage in the mainland), ended a zodiac cycle that began with the Year of the Rat in 2008, the year of the Beijing Olympics - often referred to as the official 'coming-out' party of the People's Republic of China (PRC).

By 2019, China had well and truly arrived. It boasted the second biggest economy in the world and could claim significant global influence and power. Yet the ongoing tit-for-tat trade war with the United States afflicted an economy already undergoing its own difficult internal readjustments - even if, by the year's end, the two sides had signed a (precarious) 'phase one' of a peace deal. In Hong Kong, the nightmarish and increasingly violent cycles of protest, police suppression, and popular reaction that began with peaceful mass demonstrations in June showed no sign of 
abating. The US Congress infuriated the Chinese leadership by passing the Hong Kong Human Rights and Democracy Act and the Uyghur Human Rights Policy Act. While Beijing did its best to show a unified and defiant face to the world, three spectacular and unusual leaks of secret documents revealed the possibility of cracks beneath the surface of unity. These leaks included two tranches of documents concerning Xinjiang, one published by The New York Times and the other by the International Consortium of Investigative Journalists, as well as a collection of speeches made by China's top leaders immediately following the events of 4 June 1989, in which they discussed what amounted to a playbook for dealing with future mass movements.

The Daoist philosopher Zhuangzi 莊子 once dreamed he was a butterfly. When he woke up, he realised he was just a man. Then he wondered whether he was not in fact a butterfly dreaming he was a man who had dreamed he was a butterfly. As Jingjing Chen writes in 'Zhuangzi and His Butterfly Dream: The Etymology of Meng 夢', the Chinese character for 'dream' (as seen on the cover) can be a metaphor for transformation. ${ }^{1}$ To speak of a dream in Chinese is also a common way of signifying nostalgia. The character meng has historically also been used to indicate the darker side of palace politics. It would later acquire, from the Western notion of 'dreams', the meaning of ideals and aspirations, as in the China Dream 中国梦. Dreams are also illusions, as in another of Chinese culture's most famous dreams, The Dream of the Red Chamber (also translated as The Story of the Stone). Annie Luman Ren's forum, 'From the Land of Illusion to the Paradise of Truth', looks at the relationship between reality and illusion in both the classic Qing dynasty novel and the 'post-truth' media in the contemporary Chinese world.

The year 2019 encompassed dreams in every one of these senses, from transformations to illusions and aspirations - and nightmares, too. When we sat down in February 2019 to plan this China Story Yearbook, it struck us how many significant anniversaries would occur over the 
course of the year - each representing a different kind of 'Chinese dream'. These included the seventieth anniversary of the PRC - a dream of national revolution and renewal that, by the end of 2019, had become a dream of empire, with Xi Jinping's proclamation of the 'new frontier' 新境界 of 'Chinese rule' 中国之治. Xi's own power continued to grow in 2019 in both practical and symbolic ways. A set of 'morality guidelines' issued to all citizens in October not only defined the etiquette for singing the national anthem and the proper sorting of rubbish and recycling, but also called for all to 'defend China's honour abroad' and adopt Xi Jinping Thought as their moral 'core'. The guidelines made no mention of Mao or Deng Xiaoping, unlike their last iteration in 2001. The Party also quietly eliminated a passage from literary Chinese textbooks that had been part of Chinese students' education for decades, apparently for fear that its message of righteous rebellion might be taken too literally, as Esther Sunkyung Klein and Victor Fong write in 'The Changing "Dream" in the Classroom: Literary Chinese Textbooks in the PRC'.

Another highly significant anniversary is that of the May Fourth Movement of 1919. As Gloria Davies discusses in 'A Dream of Perpetual Rule', the May Fourth Movement expanded from a patriotic protest into a movement encompassing workers' and women's rights, universal education, and cultural renewal. Xi Jinping, however, in what Davies calls an 'ahistorical privileging of patriotism', has narrowed its significance to its anti-imperialist beginnings while expanding it to endorse his own administration as drawing on its 'powerful spiritual force'. She also makes the point that it is 'perhaps more important to pay attention to what Xi's China Dream does rather than what it means'.

The May Fourth Movement resonated deeply with the broad movement of pro-democracy petitioners and protesters in 1989 - a movement that ended in bloodshed when the Party ordered the army to open fire on 3-4 June that year. The thirtieth anniversary of those events, unlike that of May Fourth, cannot be publicly spoken of in China today. But all that happened on and around Tiananmen Square in 1989 has resonated 


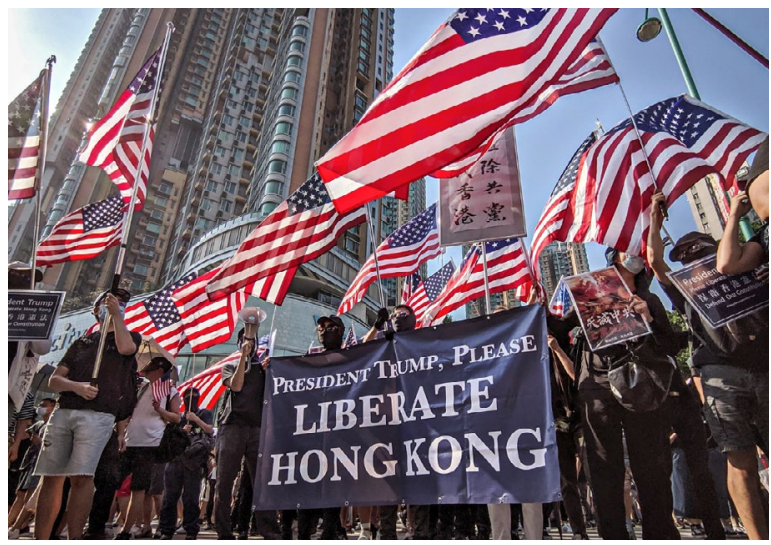

strongly in Hong Kong from the beginning. Antony Dapiran, the author of a book on the Umbrella Movement of 2014, City of Protest: A Recent History of Dissent in Hong Kong, and the upcoming City on Fire: The Fight for Hong Kong, about the current protests, sums up and analyses the events of a chaotic year in Hong Kong in 2019 - a China story that is far from over, and one that continues to be a nightmare for many.

As Louisa Lim and Graeme Smith show in their chapter, 'Hong Kong and the Tiananmen Playbook', the Party's reaction to the social and political unrest of three decades ago is a key piece in the puzzle of understanding its response to the upheavals in Hong Kong in 2019. The 'Tiananmen Playbook' also informs the Party-state's actions in Xinjiang. China's extreme repression of Uyghurs in the name of combatting 'terrorism' continued throughout 2019. Beijing heatedly denies the veracity of the leaked documents concerning the Party-state's policies and practices in Xinjiang. Yet they provide a wealth of credible detail on the Party's policies as well as rules for and conditions in the detention camps where perhaps a million or more Uyghurs and other Muslims are being held. Although the Party-state claims the detainees are receiving 'vocational training', the system appears designed to exterminate their cultural and religious 
identity. Enabling that is an ever-more sophisticated system of surveillance that, together with the evolving Social Credit System, has applications outside Xinjiang as well, as Gerry Groot writes in his chapter, 'Schemes, Dreams and Nightmares: China's Paradox(es) of Trust'. Samuel J. Parson delves into the ancient philosophical roots of these modern methods of control in 'Legalism and the Social Credit System'.

Benjamin Penny, in “"Evil Cults” and Holy Writ', notes another anniversary. It has been twenty years since Falun Gong adherents shocked the Party leadership by successfully surrounding its headquarters at Zhongnanhai in silent protest. While the Falun Gong remains outlawed in China today, Penny explains why the Party-state is currently even more worried about another religion on its official list of 'evil cults': the millenarian Church of Almighty God. Ben Hillman reflects on the second year of the Party's campaign to Sweep Away Black and Eliminate Evil 扫黑除恶, which promises to build a more harmonious society by taking down undesirable elements, including gangsters, local tyrants, and corrupt officials. The Party is also using the campaign as a tool of wider social control.

Another anniversary is that of the flight of the Dalai Lama from Tibet in 1959 following a Tibetan uprising against Chinese rule.

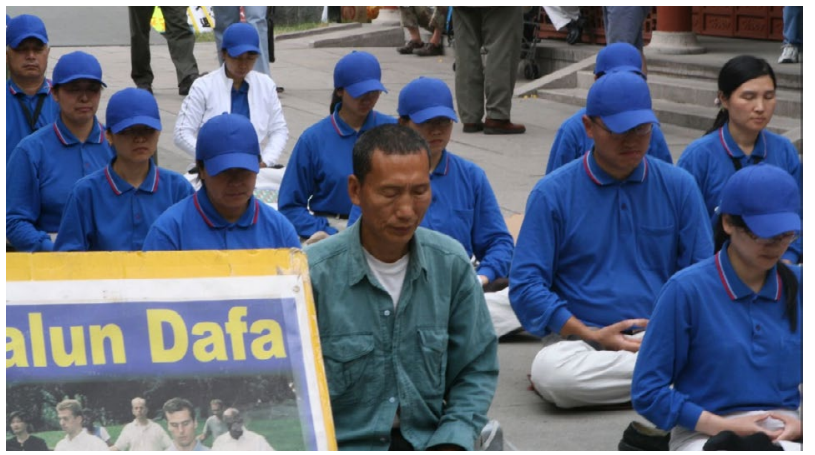


Han migration, strict policing, and surveillance, as well as targeted investment, have radically changed the face of Tibet over the intervening sixty years. One major change has been rapid urbanisation. In their chapter on 'Urbanising Tibet: Aspirations, Illusions, and Nightmares', Gerald Roche, James Leibold, and Ben Hillman examine what young Tibetans' hopes and fears are about the changing world around them and city life, as revealed through three Tibetan pop songs.

Still in the borderlands, in "Prairie Mothers" and Shanghai Orphans', Uchralt Otede unearths a forgotten piece of history behind Xi Jinping's award of the honorary title of People's Model to a 77-yearold Mongolian woman for her role in relocating thousands of Shanghai orphans and abandoned children to Inner Mongolia during the Great Leap Forward era six decades ago. Jane Brophy's Forum about two Inner Mongolians infected with the plague being mysteriously 'transported' to a Beijing hospital in November evokes a recurring nightmare with historical, environmental, and authoritarian dimensions. The foreboding story presages the outbreak of the coronavirus epidemic in the city of Wuhan in January 2020.

The dreams of Taiwan's LGBTQ community came true in 2019 when Taiwan became the first place in Asia to legitimise gay marriage. In 'Queer Dreams', Jamie Zhao also surveys legal changes in the mainland that may signal shifting attitudes there as well.

The May Fourth Movement advocated for 'Mr D' (democracy) and 'Mr S' (science). If Mr D had a difficult time in 2019, Mr S fared better. A number of pieces in the Yearbook survey Chinese dreams and accomplishments in science and technology, including China's emerging dominance in some sectors - and some of the controversies this has engendered. Adam Ni looks at how private entrepreneurs are working with state bodies to realise China's 'space dreams'. In 'Dream Babies', Jane Brophy discusses the Chinese scientist who - horrifying many in the international scientific community for his violation of international ethical standards - helped bring to term the world's first 
genetically modified babies. Darren Lim and Victor Ferguson tackle the tricky topic of Huawei and the Sino-US trade war in 'Conscious Decoupling: The Technology Security Dilemma'. Olivia Shen, in 'AI Dreams and Authoritarian Nightmares', writes about the implications of China's ambitious plan to lead the world in the theory and technological application of artificial intelligence (AI) and to become the global centre for AI innovation by 2030.

Abroad, the footsteps of the China Dream continued to grow in 2019, including through the ever-expanding Belt and Road Initiative. But anti-China sentiment was also rising. This is partly due to revulsion at the state's actions in Xinjiang and sympathy for the demands (if not always the methods) of the Hong Kong protesters, and partly due to the discomfort of many in the West at the prospect of a powerful China rewriting the rules of the 'rules-based order'. Such issues as whether Huawei should run $5 \mathrm{G}$ networks in other countries continue to create problems and tensions. Arrests of more than a dozen Canadian citizens in retaliation for Canada's detention of Huawei executive Meng Wanzhou 孟晚舟 for extradition to the United States, has badly strained once-friendly Sino-Canadian relations. Elsewhere, it is the footprint of the China Dream itself that feels heavy: in 'South Korea and the "China Effect"', Hyung-Geun Kim discusses the choices and challenges faced by South Koreans with regard to the Belt and Road Initiative, and ChiungChiu Huang, in 'Taiwanese Dreams: Security, Sovereignty, and the Space to be Seen', delivers a Taiwanese perspective. Beyongo Mukete Dynamic, meanwhile, casts a cool eye on China's Antarctic dreams in 'Antarctic Ambitions: Cold Power'. Richard Rigby and Brendan Taylor look at the big picture in their chapter, 'Meridians of Influence in a Nervous World'. Finally, in 'Campus Conundrums: Clashes and Collaborations', Jane Golley, Paul Harris, and James Laurenceson examine the situation on Australian university campuses, which were front and centre in news stories about Chinese influence and interference throughout the year. 


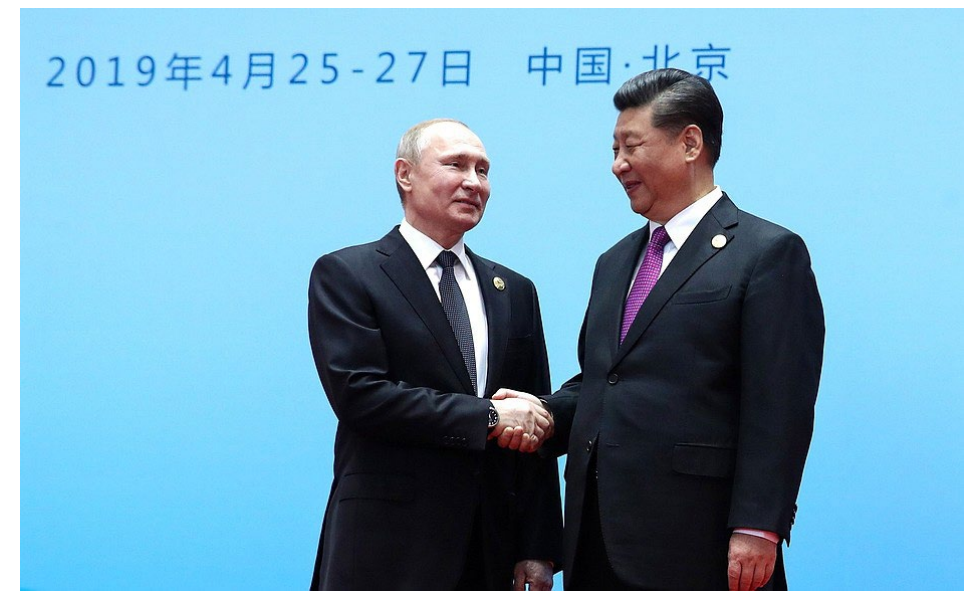

Vladimir Putin and Xi Jinping at the 2019 Belt and Road Forum for International Cooperation Source: TASS, President of Russia

In thinking about the lessons of the year, we return to another of China's most famous dreams, the Golden Millet Dream 黄梁梦. In it, a young scholar — poor, unmarried, and having just failed the imperial examinations in Beijing - arrives at a small inn, feeling very sorry for himself. He meets a Daoist priest there, who urges him to sleep, and gives him a special pillow. As the scholar falls into a deep sleep, the innkeeper is cooking a pot of golden millet for lunch. In his dream, the young scholar marries a beautiful woman from a noble family. He passes his examinations and becomes a high official and enjoys great wealth. He and his wife have five sons, all of whom become high officials, marry well, and give him many grandsons. He lives a long and fulfilling life, though there are dramas and tragedies as well. At the age of eighty, he becomes ill but just as he is about to take his dying breath, he opens his eyes and realises he is back in the inn and the millet is still cooking. Only a short time has passed. The Daoist priest is still sitting by his side. 'Was that really just a dream?', the young scholar asks. The Daoist replies that wealth and glory and all the rest are but illusions, and all things pass. 


\section{Acknowledgements}

The China Story Yearbook is a project initiated by the Australian Centre on China in the World (CIW) at The Australian National University (ANU). It has always been the approach of the Yearbook to view political and economic developments as part of a greater picture that encompasses society, personalities, and culture, and one that is illuminated by considerations of language and history. Our ongoing reference to the China Story 中国 的故事 reflects the principle set out by CIW Founding Director, Emeritus Professor Geremie R. Barmé, that China's story is not only the version portrayed by the Chinese Communist Party, but also includes the diverse perspectives of a multitude of others, within and outside the PRC.

Many of the subjects we cover in this year's China Story Yearbook are topical in ways we could not have anticipated when we first began commissioning the contributions in mid-2019. Co-editors Jane Golley, Linda Jaivin, Ben Hillman, and Sharon Strange are enormously grateful to all the wonderful scholars and other contributors, new and old, who have taken the theme of dreams and applied their unique knowledge, insight, and observation to come up with another great collection of essays that we are proud to publish. The China Story Yearbook is truly a collaborative effort. We also thank Chin-Jie Melodie Liu for her assistance with typesetting the book, Jan Borrie for copyediting the book, and two anonymous referees for taking the time to read and comment on it prior to publication, as well as our designers from CRE8IVE, Laura Sibley and Josh Garrard.

\section{The Cover Image}

The character at the centre of this Yearbook's cover is meng 梦 (夢 in traditional characters). Readings of this character have changed from early references to dimness, gloominess, and even chaos in an obscure environment, to a metaphor for a forever-lost life (and its material 
pleasures). Since 2013, however, the character has been used in the phrase the 'China Dream' 中国梦. That was the inspiration for this Yearbook's English title, China Dreams. The concept of the China Dream was first coined by $\mathrm{Xi}$ Jinping. It describes a set of personal and national ideals. The phrase is a loan translation: it follows the rendering of the 'American Dream' as Meiguo meng 美国梦. For more information on the etymology of meng, see the Introduction Forum 'Zhuangzi and His Butterfly Dream: The Etymology of Meng 夢', pp.11-14.

The large red circle that encompasses

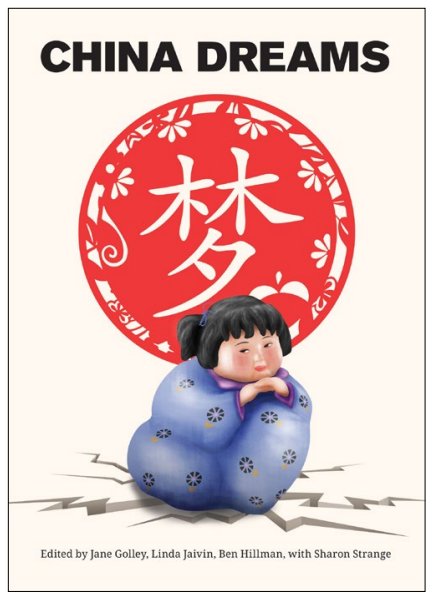

Cover of the China Story Yearbook: China Dreams

Artwork: CRE8IVE, Canberra the character meng echoes the aesthetics of traditional Chinese papercutting 剪纸. Present throughout China, paper-cutting is a popular art integral to everyday lives. Designs vary greatly and adopt a range of regional styles. They are used for interior decor, festivities, or prayer.

The girl on the front cover is the China Dream girl. She is a clay figurine nirenzhang, 泥人张. She was the main image of the Chinese Communist Party propaganda campaign used to promote the China Dream in the early 2010s. She regularly appeared on government billboards with the phrase: 'The China Dream, My Dream' 中国梦, 我的梦. With an innocent expression and flushed cheeks, she presented the campaign's most human vision of the dream. 


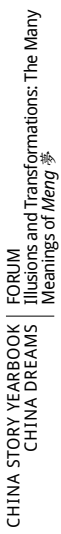


论坛 


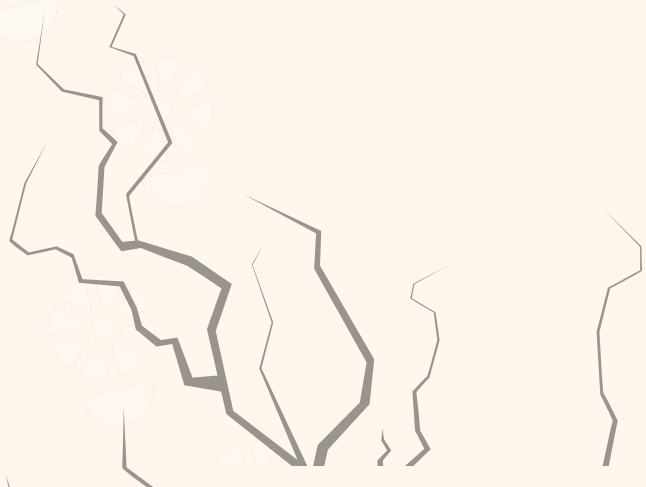

ILLUSIONS AND TRANSFORMATIONS: THE MANY MEANINGS OF MENG 夢

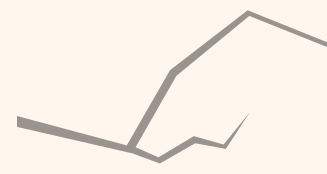

From the Land of Illusion to the Paradise

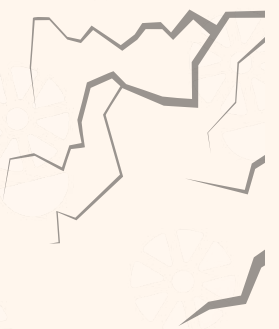
of Truth

- ANNIE LUMAN REN

Zhuangzi and His Butterfly Dream:

The Etymology of Meng 夢

- JINGIING CHEN
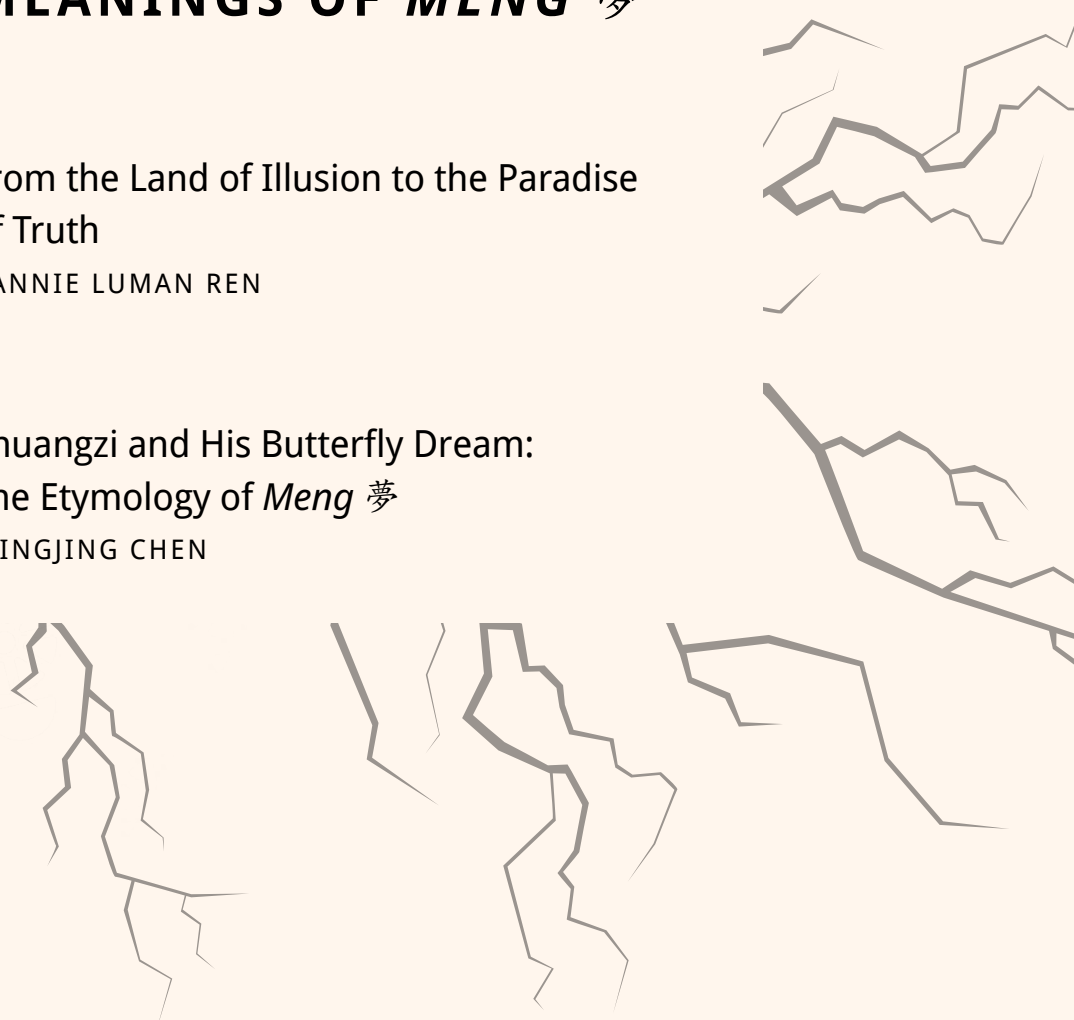
$\frac{4}{5}$

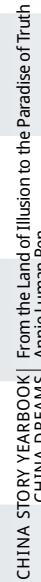




\section{FROM THE LAND OF
ILLUSION TO THE PARADISE
OF TRUTH
Annie LUman Ren}

$\mathrm{T}$

HE 2019 CHINESE Lunar New Year celebration began with the usual display of fireworks. But what really caught the public eye was an article with the over-long title — 'I Showed My Syrian Friend a Video of Fireworks from Lunar New Year's Eve, He Burst into Tears'. First published on College Daily 北美留學生日報, a WeChat-based publication operating from New York and Beijing, the article tells a moving story of how the fireworks reminded the author's Syrian friend of the bombings in Damascus and the death of his brother, causing him to weep. In this article, the author Deng He (pen name He-He), expressed a mixture of hope for peace in Syria and the world, indignation at Western imperialism and colonialism, and a sense of pride in being born in the People's Republic of China (PRC) - a rising yet peaceloving global power. The article quickly gained more than 100,000 views, and was reposted by all major Chinese government media outlets including the People's Daily, Global Times, Xinhua News Agency, and the Chinese Communist Youth League. ${ }^{1}$

Six months later, The New Yorker published an investigative piece detailing College Daily's transition from 'a bare-bones survival guide' for Chinese students studying in North America to an influential media outlet delivering news with nationalistic overtones to Chinese students around the world. ${ }^{2}$ During an interview with the journalist Han Zhang, Deng He admitted that his piece on the Syrian friend was entirely made up. It turned out that his boss Lin Guoyu 


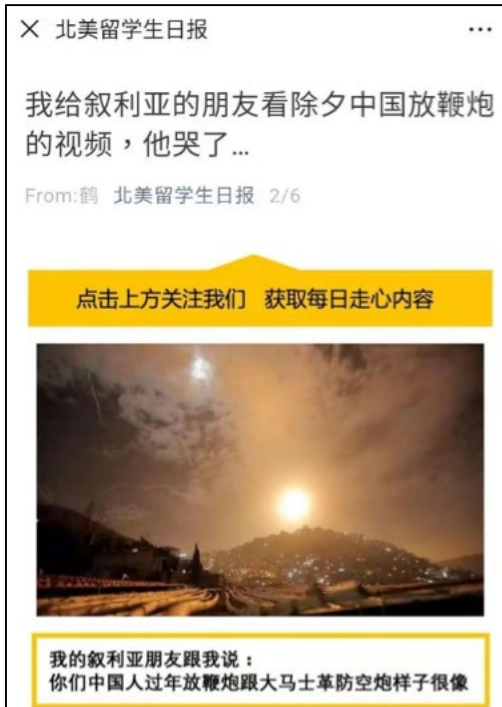

The article from College Daily begins with a photo of Damascus during an air raid

Source: College Daily

林果宇, who founded College Daily in his Beijing apartment in 2014, had come up with the idea while browsing viral videos online.

Lin himself denied the article was fabricated, but when pressed to describe the nature of his publication, he chose the term 'post-truth', a position with which College Daily readers seem comfortable. When asked to comment on the veracity of College Daily posts, a sophomore at New York University responded, 'In my heart they are simply not real and not fake.' This answer reminded the journalist Han Zhang of Schrödinger's cat. But for me, it evokes a famous couplet from the eighteenth-century Chinese classic The Dream of the Red Chamber (紅樓夢 also known as The Story of the Stone in the English translation):

Truth becomes fiction when the fiction's true;

Real becomes not-real when the unreal's real. $^{3}$

In chapter five of this novel, the protagonist Jia Bao-yu 賈寶玉, a young aristocratic fop, sees the above couplet inscribed on the lintel of an arch in a dream visit to the Land of Illusion. The dream warns Bao-yu about the illusory nature of his love for his girl cousins (and also for beautiful boys), and of the decline in his family's fortunes. Being young and ignorant, Bao-yu pays no attention to his dream. He continues to live a life of leisure inside a beautiful garden that is the main setting of the novel.

The novel - considered China's finest literary achievement - is preoccupied with details of daily life inside the garden: how tea is prepared with the last year's snow or how themes are set for poetry competitions. Tedious as it may sound, 
this is precisely the novel's appeal. What the author Cao Xueqin 曹雪芹 (1715-1763), an impoverished Manchu banner-man, spent ten painful years creating is in fact an entire universe so rich in detail that it seems more real than life itself. At the same time, Cao incessantly reminds his readers of the fictional nature of this universe. The novel begins with the meeting of two characters Zhen Shiyin 甄士鿵 and Jia Yucun 賈雨村, whose names sound like the phrases 'true events concealed' and 'false words remained', respectively. Bao-yu's surname is also Jia 賈, a play on the word for 'false or fiction' (假). In another dream, in chapter fiftysix (you can tell by now, dreams are a recurring feature of the novel), he encounters another Bao-yu, but with the surname Zhen 甄- a homophone for 'real or true' (真).
In the twentieth century, the study of The Dream of the Red Chamber became a serious academic discipline, known as 'Hong Xue' or 'Redology' 紅學, granting the novel a unique status in Chinese literature. The first 'Redologists' included eminent scholars such as $\mathrm{Hu}$ Shi 胡適, Cai Yuanpei 蔡元培, and Chen Duxiu 陳獨秀 (a founding father of the Chinese Communist Party). They all belonged to the generation of Chinese students who studied abroad, in America, Europe, or Japan, at the turn of the century. They were also leaders of the May Fourth Movement (see Chapter 1 'A Dream of Perpetual Rule, pp.19-31) advocating for the adoption of 'science' and 'democracy'. ${ }^{4}$ Ironically, in their quest for scientific truth, they and their disciples have tended to read The Dreamof the Red Chamber as a historical \begin{tabular}{|l|} 
The Dream of the \\
Red Chamber by \\
Sun Wen \\
孫溫 (1818-1904) \\
Source: Sevilledade, \\
Wikipedia
\end{tabular}

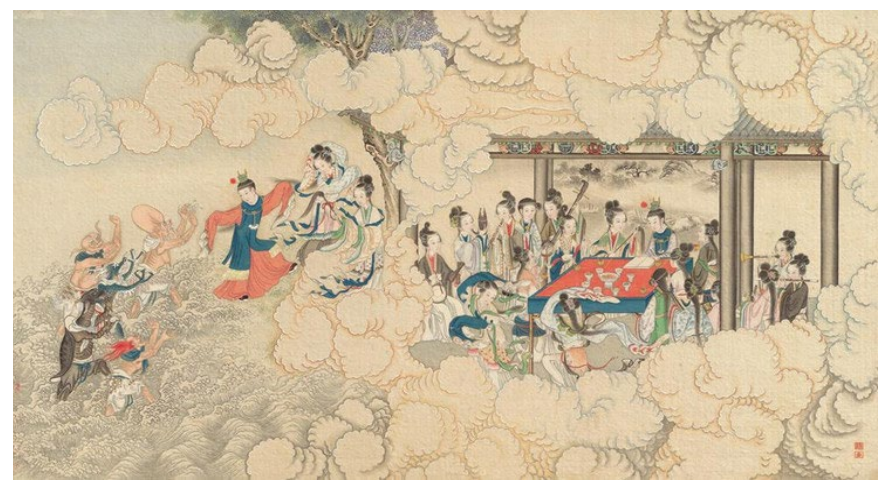




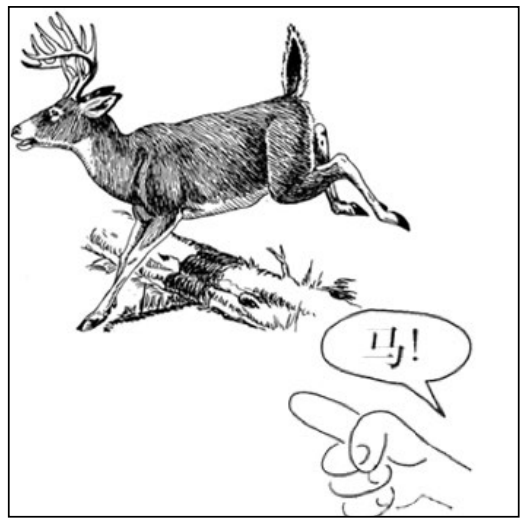

|'Pointing to a stag and calling it a horse' 指鹿為馬 Source: Rawpixel Ltd, Flickr

document on Qing dynasty society or as an almostliteralguide to the author'slife and family, thereby confusing fiction and reality.

The obsession with this novel continues into the present century. In late 2018, an article claiming to have discovered the 'true authorship' of The Dream of the Red Chamber went viral on WeChat. It has no basis in fact, yet since then, as a scholar working on this novel, I have found myself being lectured on the novel's 'true' authorship everywhere I go in China. From a retired Beijing couple on a train to my aunt who is a county-level official in Jiangsu, everyone feels the need to tell me the 'truth' about the novel I have spent years studying.
The first time this happened, I was rather amused. A line from the novel Fortress Besieged 圍城 by Qian Zhongshu 錢鍾書 (1910-1988) came to mind: 'Uneducated people are fooled by the words of others because they are illiterate; educated people are fooled by the written word because they are literate.' ${ }^{4}$ Later, I recalled another incident, from the Record of the Grand Historian 史記, written more than 2,000 years ago. You might call this China's first 'post-truth' paradigm: Zhao Gao 趙高, a prime minister in the emperor's court, wanted to test the limits of his power. He took a stag to court, pointed to it, and called it a horse. Cowed, some of his fellows remained silent, while others agreed that this was indeed a horse. As for those who dared to speak the truth, Zhao Gao had them all executed.

Unlike their forebears from a hundred years ago, many overseas Chinese students today choose to ignore the more objective sources of news and information available to them, preferring platforms such as Weibo and WeChat and, of course, 'self-media' 自媒體 outlets such as College Daily, which willingly engages in persuasively detailed 'post-truth' soft propaganda. As a result, they 
continue to live in the Land of Illusion, where a stag is called a horse. The clashes between Chinese nationalists and pro-Hong Kong protesters on university campuses worldwide are indicative of this phenomenon.

But if we can blame the continued delusions of overseas Chinese students on language differences and the authoritarian regime that currently governs China, what excuse do we in the West have for our own 'posttruth' world? Perhaps we can all learn something from reading Red Chamber Dream - a novel that constantly challenges our perceptions of truth and fiction. At the end of the novel, a sorrowful Bao-yu finally comes to the realisation that what he thought was real was, in fact, only a dream, an illusion, nothing but 'moonlight mirrored on water'. Having woken from this 'dream', Bao-yu finally leaves the fictional garden and disappears into the snow. But first, in chapter 116, he revisits the Land of Illusion in one final dream. This time, the Land of Illusion is replaced with the Paradise of Truth, and the couplet on the lintel reads:

When Fiction departs and Truth appears, Truth prevails;

Though Not-real was once Real, the Real is never unreal. ${ }^{6}$ 
10

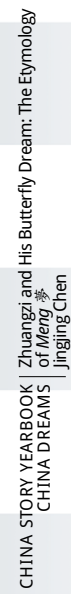




\section{ZHUANGZI AND HIS
BUTTERFLY DREAM: THE ETYMOLOGY OF MENG 夢 Jingjing Chen}

$\mathrm{I}^{\mathrm{N}}$

ZHUANGZI 莊子, an ancient Chinese text written by Daoist philosopher Zhuangzi during the late Warring States period (476-221 BCE), a story tells that Zhuang Zhou once dreamed he was a butterfly, flitting and fluttering around, happy, and doing as he pleased. As a butterfly, he did not know he was Zhuang Zhou. All of a sudden, he awoke and found he was Zhuang Zhou, solid and unmistakably human. But then he did not know whether he was Zhuang Zhou dreaming he was a butterfly or a butterfly dreaming he was Zhuang Zhou. In the end, Zhuangzi wrote, there was necessarily a difference between Zhuang Zhou and the butterfly; this difference was the 'transformation of things'物化. The transformation is a change in consciousness between reality and illusion. The constant flux between dreams and awakening leads the 'self' to change from being unaware of the distinction of things to being aware of the definite distinction between and among things.

Zhuangziis one of the foundational texts of Chinese literature and philosophy. Later interpretations of dreams in the Chinese literary tradition drew on this strange and radical story. Much discussion has focused on the nature of the atmosphere Zhuangzi created for this 'butterfly dream', and whether it was inherently optimistic or pessimistic. Two contrasting interpretative traditions have evolved: one drawing on the image of the carefree butterfly that hinted at a 
bright and soaring future; the other gloomy and melancholy, leading to a reading of 'life is but a dream'.

Despite the contrast in these perspectives, both traditions have based their interpretations of the dream in the worldly realm. By reinterpreting the dream in a worldly frame of displacement in space and time, they moved away from Zhuangzi's contemplation of the question of agency, initiative, and the 'distinction' 分 of things.

Over the centuries, the optimistic school gained the upper hand in emphasising the butterfly image in Zhuangzi's dream. Chinese scholars and poets tended to refer to Zhuangzi's butterfly dream as if it were a fixed allusion for a delightful experience. It was assimilated to descriptions of a happy existence and expressions of self-content. For example, Su Shi 蘇軾, an eminent scholar and official of the eleventh-twelfth centuries also known as Su Dongpo 蘇東坡, alluded to Zhuangzi in a poem describing a wonderful dream he had while living in the mountains. Su wrote: 'I am unaware of the bell and drum announcing the break of dawn; in my dreams I am a joyful butterfly, carefree’ 不知鐘鼓報天明，夢裹栩然蝴 蝶, 一身輕.

The more melancholy imagining of the dream - and of dreams in general - as hazy and chaotic is founded on the etymology of the character meng 夢 (梦 in simplified characters), meaning 4 多 'dream'. In its earliest appearance in the written record, the character resembled the movements of a person's eyebrows, eyes, and limbs while dreaming. Later, the radicals (the graphic components of a character that function as semantic or phonetic indicators) 'roof' $\rightarrow$ and 'evening' 夕 were added. Under the Han dynasty, the character was simplified and standardised in 'small-seal' script as 帒, similar to the modern 夢. Before the standardisation, one of most common formations of the character was 献, which comprises other semantic radicals related to 'dream'. It is worth noting that despite variations in the form of the character due to the choice of differing radicals, the graphs for a house's roof and the sun at dusk - representing dimness and darkness in a restrained space - have always figured in its main semantic form.

One of the lines in the Book of Songs 詩經 (eleventh-seventh centuries BCE), in which meng 


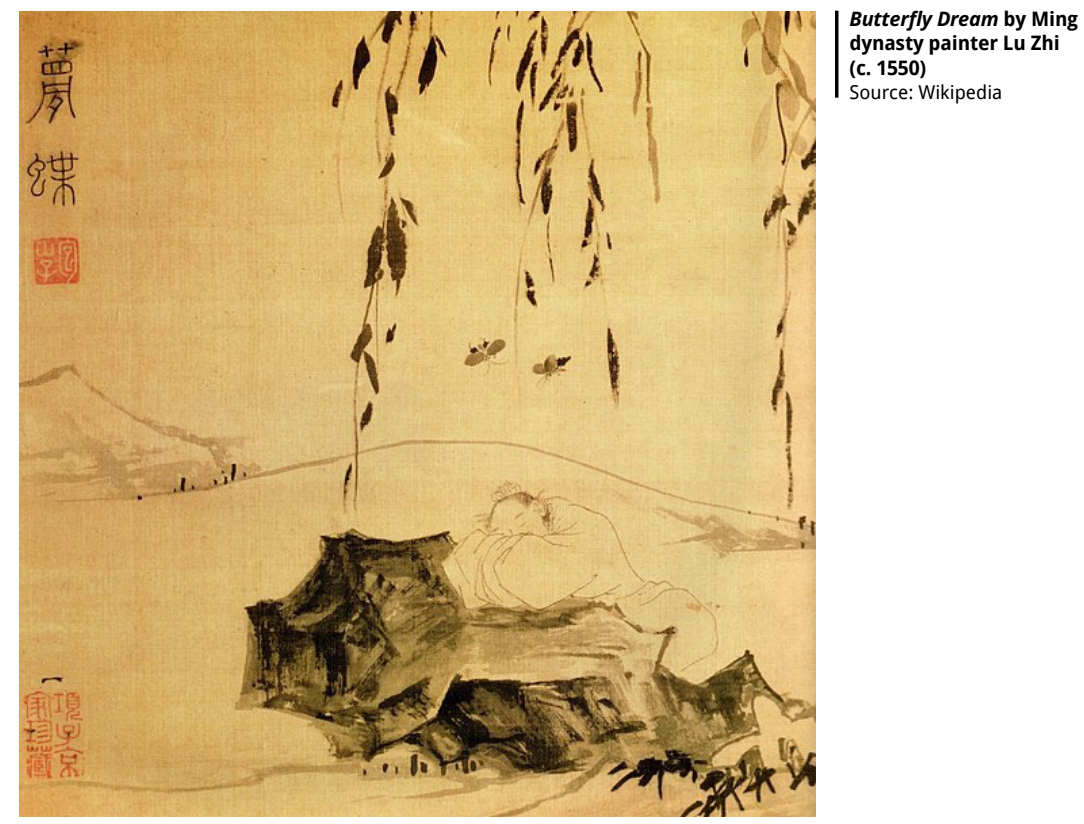

appears, reads: 'When I see you so mengmeng, my heart is full of pain' 視爾夢夢, 我心惨慘. Here, meng implies 'dark' or 'confused'. Readings of meng expanded to include dimness, gloominess, and even chaos in a dark environment. In commentaries of the Han dynasty, the character was restricted solely to descriptions of the mood of an individual. From the Tang dynasty of the eighth century, it pointed to an interaction with the wider world and extended to descriptions of murkiness and disorder in society. Since this time, classic exegesis began using the character meng in descriptions of the unresolved and chaotic politics of the imperial court.

After the thirteenth century, scholars became less likely to interpret meng as being closely tied to the meaning of its component radicals, but they still understood it in the context of worldly life. They referred more to how dreams reflect the displacement of time and space. The literature of late imperial China (1368-1911) included many works with 'dream' in the title, exploring dreams as memories of 
life in the past. Many such works were written by members of the nobility whose families had declined, sometimes in parallel with dynasties or societies as a whole, and who no longer enjoyed a privileged lifestyle. Here, the dream became a metaphor for a forever-lost life (and its material pleasures) - a lament for displacement in space and time. Notable examples are Dream Recollections of Tao'an 陶庵夢憶 and Searching for the West Lake in Dreams 西湖夢寻 by Zhang Dai 張岱 after the fall of the Ming in 1644, and The Dream of the Red Chamber 紅樓蓦, written by Cao Xueqin 曹雪芹 and published in 1791, after a marked decline in his family's fortunes when the Qing dynasty itself was beginning to decay after having reached its high point in the late eighteenth century (see Introduction Forum 'From the Land of Illusion to the Paradise of
Truth', pp.5-9). These and other works drew on sentiments from Zhuang Zhou's dream but tied the idea of the dream to material existence. Metaphysical discussions of Zhuangzi's final question about the blurring of divisions, the so-called transformation of things, and the pursuits of spiritual existence, were seldom mentioned.

The current meng 夢 in the China Dream 中國夢 is a modern concept, a cherished aspiration and an ideal dream 夢想 that do not really capture the past ideas of dreams in Chinese texts such as Zhuangzi. The phrase of the China Dream itself, linguistically speaking, is a calque or loan translation following the word construction of meiguo meng 美國夢, translated from the American Dream. Thus, in the modern period, the character meng takes on new meanings by connecting China to the cosmopolitan world. 



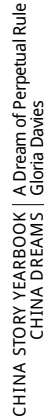




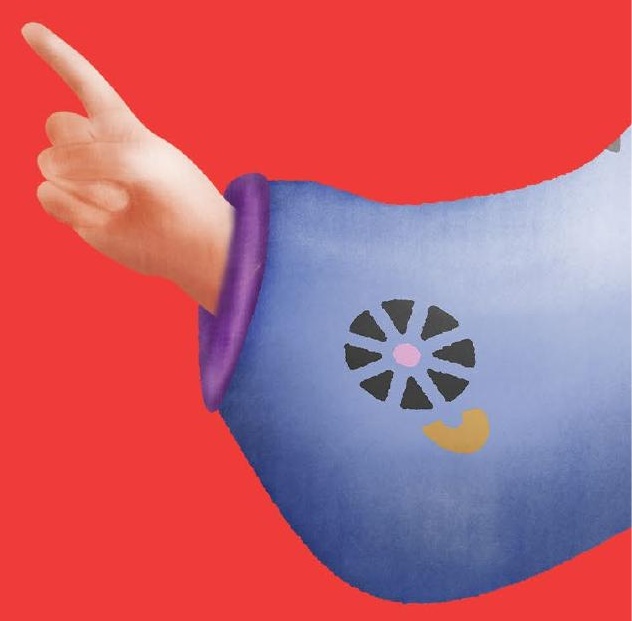




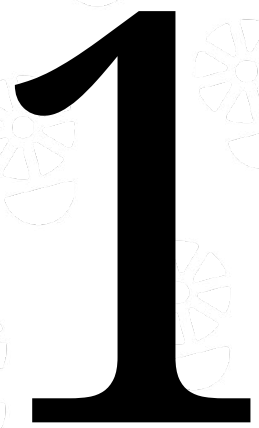




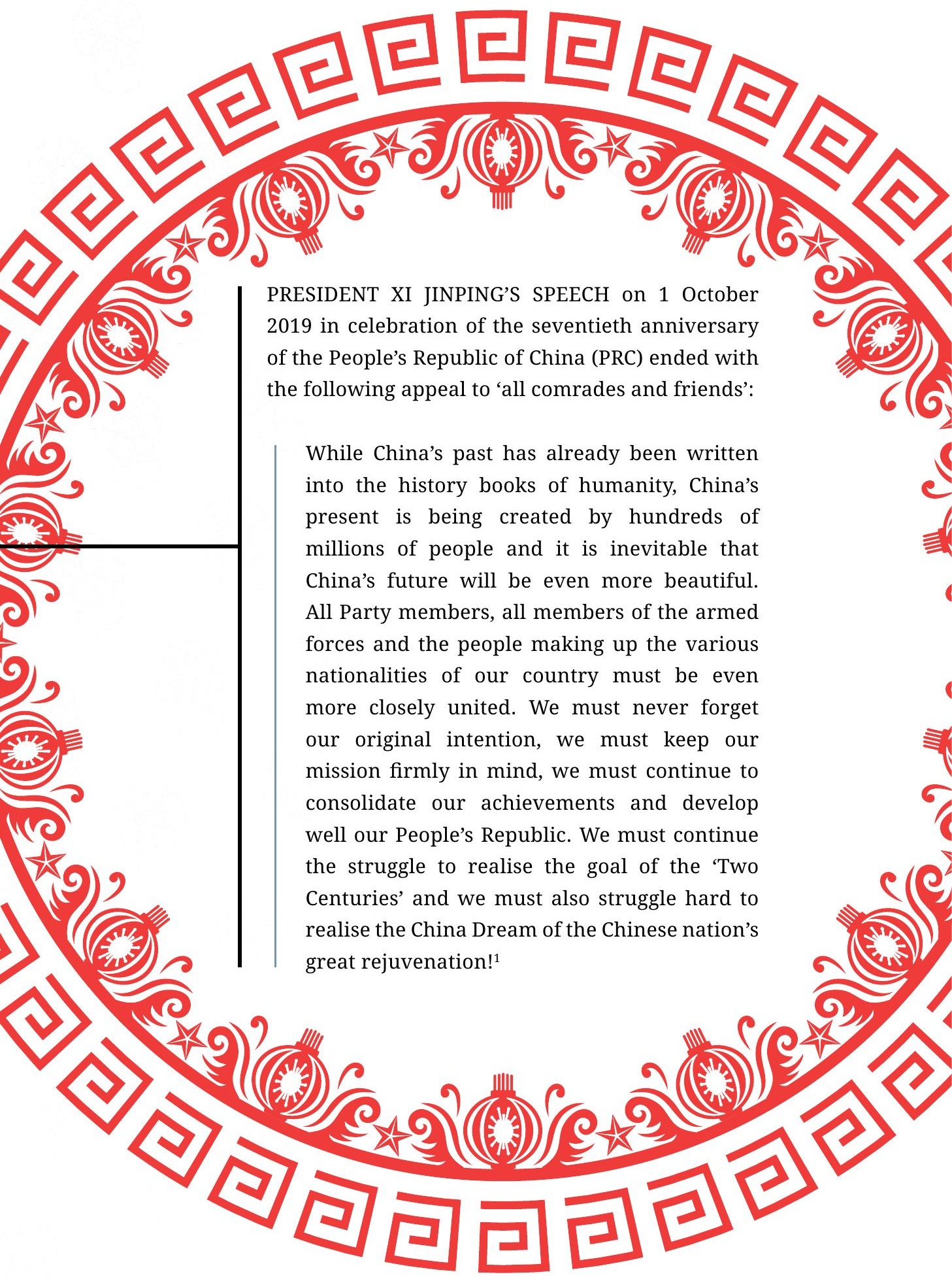


Even among people who grew up in mainland China or live there today, a large majority may have only a vague understanding of the meaning of opaque expressions such as 'our original intention', 'the goal of the “Two Centuries”' and 'the China Dream of the Chinese nation's great rejuvenation'. Nonetheless, for Chinese citizens, regardless of how much or how little they understand the slogan-saturated language used in speeches by Chinese Communist Party (CCP) leaders, this language is an unavoidable part of everyday life. They encounter it from the time they enter kindergarten and thereafter throughout their formative years, daily in the media, and in the workplace. The Party's slogans, songs, and spectacular national day parades, and the images and stories it projects of China's past and present, are interwoven into people's memories of school life and public holidays.

This enforced familiarity with the Party's language is essential for understanding the China Dream as a signature idea of Xi's administration. It is perhaps more important to pay attention to what the China Dream does - how the term operates and what it enables - rather than what it means. For one thing, the tifa 提法 (prescribed formulation) in which the China Dream appears tells us that the term relates to the Party's avowed goal of achieving 'the Chinese nation's great rejuvenation'. Comprehending the China Dream requires understanding of the CCP's preoccupation with the use of tifa.

\section{Linguistic Encumbrances}

In everyday Chinese, tifa refers simply to how an idea or topic is commonly expressed. In the Party's vocabulary, however, it signifies the (one) correct way ( $f a$ ) of discussing an issue ( $t i)$. The term was first widely adopted as a tool of government during Mao Zedong's time in power (1949-1976). The Party requires all PRC officials to adhere to the specific wording approved by the party leadership so that their public 
communications project a picture of 'unwavering' 不动摇 (a favoured party adjective) unity. ${ }^{2}$ While political parties everywhere undoubtedly want their members to speak with one voice, the CCP may severely punish individuals who do not 'maintain a unified calibre' 统一口径 that is, stay on message.

While Mao lived, he wielded such power that his choice of words also known as Mao Zedong Thought - became the only tifa that mattered. People accused of transgressing against Mao or Mao's Thought ended up in jail, labour camps, or dead. The awe that Mao commanded in life, including the extreme cult of personality he enjoyed during the Cultural Revolution (1966-1976), made it impossible for his successors to consign Mao's Thought to the past after his death in 1976. Deng Xiaoping and other Party leaders adjudged the Cultural Revolution 'a catastrophic decade' and implemented economic policies opposite to Mao's. But Deng nonetheless asserted in 1980 that any attempt to discard 'the banner of Mao Zedong Thought' would be 'nothing less than to negate the glorious history of our Party'. Every post-Mao administration, including Xi's, has invoked Mao's Thought even as it introduced new tifa to consolidate its own authority.

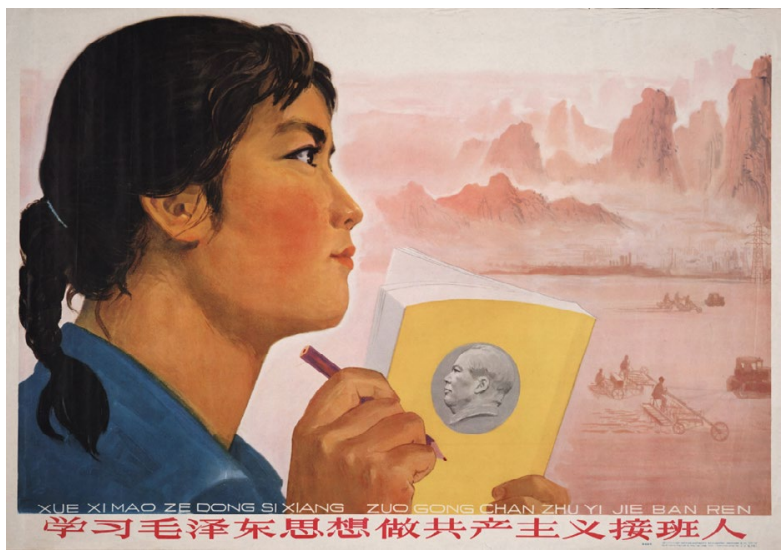


The use of tifa bears a distinct similarity to what Alexei Yurchak calls 'hypernormalisation' in his study of language use in the late Soviet Union. According to Yurchak, the leaders of post-Stalin administrations slavishly replicated formulations that had first enjoyed authority under Joseph Stalin, as if by clinging to established discursive norms they were demonstrating the Communist Party-state's enduring legitimacy and their own fitness to rule as Stalin's heirs. As social and cultural change gathered pace, however, the more the Party insisted on the authority of its 'fixed and cumbersome forms of language', the more the increasingly cosmopolitan Soviet citizenry on whom it had been imposed took to parodying it. ${ }^{3}$ Consequently, in the late 1980s, when Party leaders belatedly called for official communications to provide 'real self-criticism' and admit 'real problems', the Party's language proved incapable of doing so convincingly; its hypernormality was too entrenched. ${ }^{4}$

Xi has used the collapse of the Soviet Union in 1991 to warn Party members against complacency regarding the CCP's own future. He has stressed the importance of 'strengthening ideological and political work' to prevent a similar outcome in China. In a 2013 speech, he opined that former Soviet president Mikhail Gorbachev's admission, in July 1991, that 'Communist thinking had become obsolete for him', signalled a decisively negative turn for the Soviet Union. ${ }^{5} \mathrm{Xi}$ asked rhetorically: 'When the spirit of conviction no longer exists, where is the core of a Party and a country?' ${ }^{6}$

Xi's anxieties about waning faith in CCP rule hint at why he has adopted the China Dream as his watchword. 'Dream', in the Party's tifa — and unlike its more classical meanings (see Introduction Forum, 'Zhuangzi and His Butterfly Dream: The Etymology of Meng 夢', pp.11-14) — is synonymous with desire: people must want, or be taught to want, 'the Chinese nation's great rejuvenation', and they must also see this rejuvenation as achievable only under CCP rule. For this reason, Xi often juxtaposes two tifa featuring the ubiquitous Mao-era word 'struggle', using this word to signal fidelity to Communism's 'original intention'. As he stated in his 1 October 2019 speech: 'We must continue the struggle to realise the goal of the "Two 
Centuries" and we must also struggle hard to realise the China Dream of the Chinese nation's great rejuvenation!' The fact that 'struggle' in Mao's time meant 'class struggle' - a cause his successors have long abandoned — is, tellingly, never mentioned.

The 'Two Centuries' refers to the upcoming centenaries of the CCP's founding, in 2021, and that of the PRC, in 2049. The Party has publicly committed to achieving 'moderate prosperity' throughout China by 2021 and delivering 'democracy, harmony, strength and wealth' by 2049. ${ }^{7}$ Each of these goals comes with its own set of painstakingly formulated tifa, for they also form part of the Twelve Core Socialist Values launched at the Eighteenth National CCP Congress in November 2012, when Xi was inaugurated as the Party's General Secretary. The constant reiteration of these Xi-era formulations in speeches, media articles, and commentary aims to demonstrate the Party's clarity and unity of purpose and to instruct citizens how to resonate with the Party's will in their own communications.

\section{Propagating the China Dream}

Censorship and propaganda go together. The China Dream is the propagandistic corollary of the harsh measures Xi's administration has used since 2013 to rein in online parody of the Party's language, which had spread throughout the 2000s and into the early 2010s. Previously, parodies took the form of ditties and jokes passed on through friendship networks; they had no hope of 'going viral'. China's Party leaders know that in the digital age, censorship is a poor tool for suppressing the expression of public discontent with Party-state rule. They have thus sought to win people over with their China Dream campaign. Individuals appearing in talent contests and reality TV programs - the favourite entertainment of a majority of mainland viewers - tend to speak effusively of their 'dreams'. The China Dream provides a handy device for linking the Party-state's goals to those of individuals. 


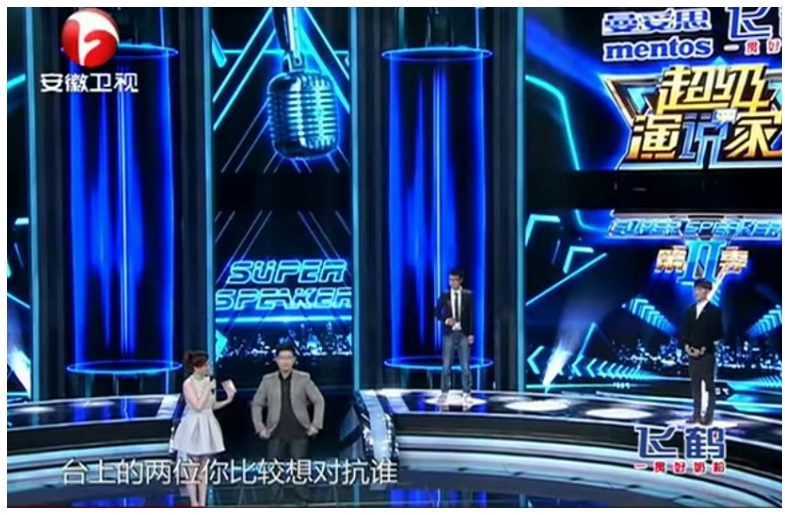

On 23 March 2013, Xi nodded to this link when he said:

In the final analysis, the China Dream is the people's dream for it is entirely dependent on the people for its realisation, and so this is a dream that must constantly work to benefit and enrich the people. ${ }^{8}$

State-run media regularly quotes this and other statements by Xi that highlight the intertwined nature of the China Dream and the dreams of individual Chinese citizens.

University of Sydney anthropologist Gil Hizi's study of China Dream propaganda notes that, since 2013, the Party has employed both staterun and privatised initiatives to equate the CCP's goals with the China Dream of delivering a good life to the people. ${ }^{9}$ Schools encourage students to write essays and make speeches about their personal dreams as part of the China Dream and several universities have held public speaking competitions on the theme of 'China Dream, My Dream'.

State censorship and surveillance, coupled with the threat of severe penalties, have nearly succeeded in wiping out online ridicule of China Dream propaganda. On Bilibili, China's leading video-sharing website, 
vox populi-style clips have appeared of people talking positively about the China Dream and what it means to them personally. The majority of comments on the videos are positive, with only a few users leaving sardonic remarks such as: 'Watching this makes me think of this [meme]: "With a population of 1.4 billion, it's no surprise there are some stupid $\mathrm{c}^{* *}$ ts in China. Do you think you're living in a paradise?" ${ }^{10}$ Another user queried: 'Shouldn't the China Dream begin with a hard disk repair?'11

Conflation of propaganda and entertainment is integral to ideological strengthening under Xi. Analysing three televised public speaking contests revolving around the China Dream, Hizi writes that contestants in Super Speaker, I am Speaker, and Wonderful China - aired respectively in 2013, 2014, and 2015 - all told stories of personal triumph in the style of 'filial nationalism'. They

echo the message of the China Dream by offering visions of the future through relying on a shared past. They bring into life an imaginary in which stability and reform, conformity and innovation, obedience and self-expression, are by no means antonymic concepts. ${ }^{12}$

A good example of the Party's recent efforts at encouraging identification with CCP ideology through entertainment is The Leader 领风者, a cartoon series about the life and times of Karl Marx released for streaming on Bilibili on 28 January 2019. Made to commemorate the 200th anniversary in 2018 of Marx's birth, this seven-episode series was an initiative of the Central Office for the Research and Construction of Marxist Theory 中央 马克思主义理论研究和建设工程办公室. The Hangzhou-based animation company Wawayu TV produced the series with support from the Inner Mongolia branch of the Party's Propaganda Department and the Inner Mongolia Film Group, which the Propaganda Department controls. The Chinese Academy of Social Sciences (CASS) and the Propaganda Department of the Communist Youth League were also involved in the production. ${ }^{13}$ 
In The Leader, Communism's founding father is depicted as tall, slim, and wide-eyed, with a high forehead, well-defined jawline, arched brows, and dark wavy hair - resembling any number of popular heroic male anime characters. The point was to 'reinvent and broadcast Marxism as widely as possible, [to] bring Marx and Generation Z together', as the title of a Guangming Daily editorial put it. ${ }^{14}$ However, an article published in the online magazine Sixth Tone pointed out that The Leader also had the unintended effect of leading viewers to pay 'more attention to Marx's high cheekbones and good looks than his theories'. ${ }^{15}$

The Guangming Daily editorial's gushing endorsement of the cartoon series was to be expected. This newspaper is directly controlled by the CCP's Central Propaganda Department (CPD). The Shanghai-based Sixth Tone, conversely, is an English-language outlet owned by the Shanghai United Media Group, a commercial operation supervised by the Shanghai Committee of the CCP. Its primary audience is an international Anglophone readership. Sixth Tone's good-humoured criticism of the cartoon series is characteristic of this outlet's more sophisticated approach to 'maintaining a unified calibre' with the CPD. Self-described as covering 'issues from the perspectives of those most intimately involved to highlight the nuances and complexities of today's China', Sixth Tone's editors and writers ensure that the engaging content they publish never amounts to serious dissent. ${ }^{16}$

In a 2016 article about Sixth Tone's equally readable Chinese-language sister publication, The Paper 澎看, the China Media Project’s David Bandurski points out Xi's description of effective propaganda in 2015 as being capable of extending its 'tentacles' to 'wherever the readers are, wherever the viewers are'. He elaborates on Xi's octopian metaphor:

Propaganda can no longer repulse, as it has so often done in the past, with its dead and colourless reports. It must attract. More to the point, it must attach. It must reach out to us and attach itself to us. Draw us in and lead us along. We must say: What a wondrous creature this is! Look at the way it lives and breathes, and coils itself around our lives! ${ }^{17}$ 


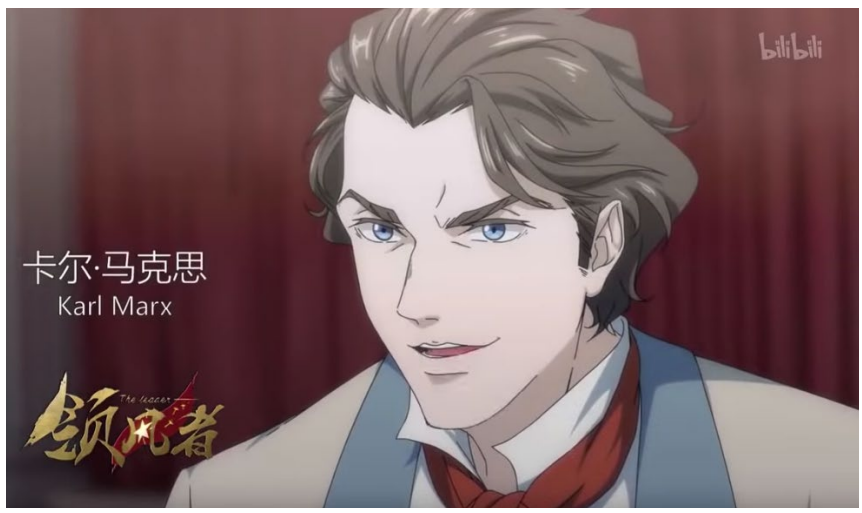

The injection of entertainment value into party ideology does not make it less coercive. If rigid and formulaic party tifa reflect a hypernormal - hence pathological - insistence on linguistic conformity to signify the Party's lasting power, the use of anime, rap, and other forms of entertainment culture to exalt the Party turns everything into grist for the Party's ideological mill. In an interview, Zhong Jun 钟君, a researcher at CASS and head writer for The Leader, likened the 'revolutionary' series to the work of intellectuals in the 1910s, whose self-declared 'literary revolution' brought modern standard Chinese into existence:

The transition from the premodern literary language [文言文 wenyanwen] to the modern vernacular [白话 baihua] was a revolution. Our adaptation of theoretical discourse into a language intelligible to the masses is similarly a revolution. ${ }^{18}$

\section{Disfiguring May Fourth}

The 'literary revolution' that took place from 1915 until the early 1920s was a cultural movement initiated by progressive intellectuals based at Peking University. These included, among others, the CCP's two most prominent founders, Chen Duxiu 陈独秀 (then Dean of Arts at Peking 


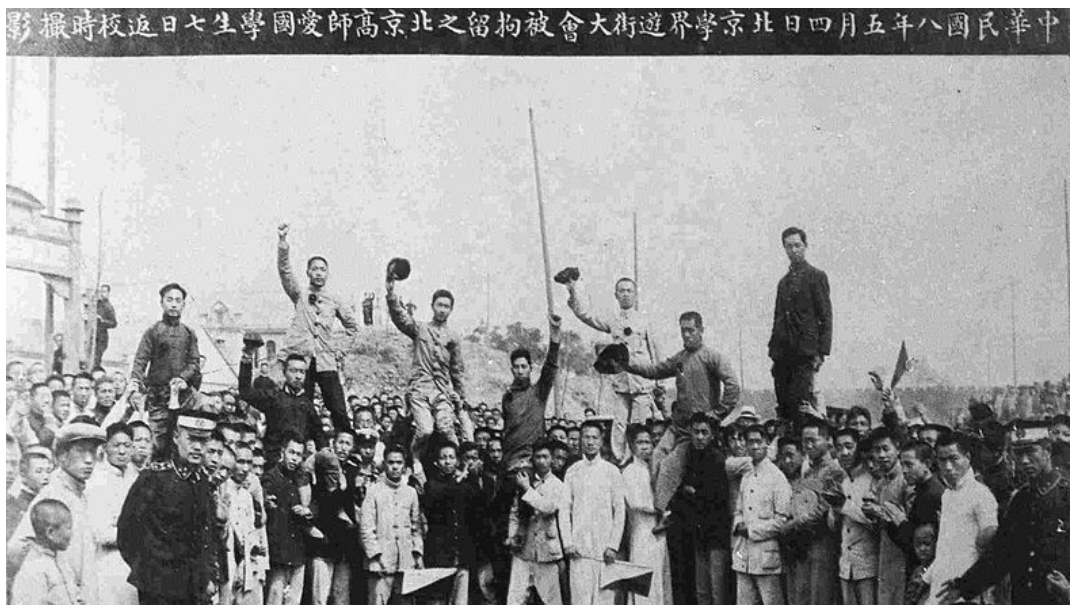

Students of Beijing Normal University returning to campus after being detained during the May Fourth Movement

Source: Sgsg, Wikipedia

University) and Li Dazhao 李大㻇 (the university’s chief librarian), as well as Lu Xun 鲁迅 (China's best-known twentieth-century writer, whom Mao posthumously lauded as 'the sage of modern China') and $\mathrm{Hu}$ Shi 胡适 (China's foremost liberal thinker). These individuals despaired that even after the collapse of the Qing dynasty (1644-1911) and the founding of the modern republic in 1912, China had failed to modernise. They vowed to eradicate everything 'old' that was holding Chinese society captive to the oppressive habits of its dynastic past. They espoused a New Culture (新文化 xin wenhua) that would deliver mass literacy through the nationwide adoption of a modern, plainspoken language (白话 baihua), based on the Beijing dialect. They perceived China's difficult premodern literary language (文言文 wenyanwen) to be a tool of oppression, accessible only to the elite scholar-official class (as 士, 绅士, 士大夫, or 文人, shi, shenshi, shidaifu, or wenren). They hoped that baihua, as a language in which ordinary Chinese people could express themselves freely, would help to bring into existence a just and democratic society. 
Zhong's comparison of the propagandistic cartoon The Leader with the New Culture advocacy of baihua as an egalitarian language that belongs to everyone may seem egregious. But 'Make the past serve the present, make the foreign serve China'古为今用, 洋为中用 was one of Mao's favourite sayings, and one that Mao's successors have turned into an authoritative tifa. Xi, who has quoted this saying on several occasions, evidently sought to make the legacy of New Culture intellectuals serve his ends when he commemorated the centennial of the May Fourth Movement in 2019.

New Culture and 'May Fourth' 五四 are often used interchangeably, with the former being generally subsumed under the latter. Student activists of the New Culture movement initiated the historic street protest in Beijing on 4 May 1919. Sparked by the poor treatment China received at the signing of the Treaty of Versailles, May Fourth expanded from a political protest to a national social and political movement that encompassed workers' rights, women's rights, and universal education. Mao's 1940 description of May Fourth as the starting point of China's 'history of "cultural revolution"' has ensured the reverential observation of this anniversary in the PRC ever since. In Xi's speech of 30 April 2019, he narrowed the significance of May Fourth to the patriotism shown by 'progressive students and intellectuals' who led 'the broad masses' in a 'thoroughly anti-imperialist and anti-feudal great patriotic revolutionary movement'. ${ }^{19}$

Xi used these Mao-era tifa to evoke continuity with Mao while suppressing the discourse of 'cultural revolution' that these tifa originally served. Instead, he claimed that May Fourth offered 'profound historical evidence' of 'patriotism flowing in the veins of the Chinese nation past and present, irremovably, indestructibly, and inextinguishably'. This ahistorical privileging of patriotism allows $\mathrm{Xi}$ to tie the achievements of May Fourth to those of the CCP under Mao, after Mao, and up to his own administration, as the workings of the same eternal 'powerful spiritual force'. 
Xi used his own tifa - 'to realise the China Dream of the Chinese nation's great rejuvenation' - six times (with minor variations), first in his opening paragraph and then as a concluding refrain to different sections of his speech. Coupled with his eleven other mentions of 'great rejuvenation' and twenty-eight references to the New Era (a temporal designation understood to mean Xi's era, which began in October 2017 with the inauguration of 'Xi Jinping Thought on Socialism with Chinese Characteristics for a New Era'; see China Story Yearbook: Power, Chapter 2 'Talking (Up) Power', pp.37-48), Xi effectively reduced May Fourth to a mere rhetorical device for exalting CCP rule under his stewardship. Of the twenty-eight references to New Era, twenty-two were to 'Chinese youth in the New Era' 新时代中国青年. Xi was, in this instance, emulating the celebration of youth in both New Culture writings and Mao's speeches. He exhorted 'China's youth in the New Era' to

continue developing the spirit of May Fourth, to take the realisation of the Chinese nation's great rejuvenation as their personal responsibility, to betray neither the Party's and the people's expectations of them nor the trust the nation has placed in them, and to never fail to live up to this great era of ours.

Party discourse is circular and self-referential because its function is to demonstrate that the Party's word is law. Xi's speech is no exception. The China Dream, so construed, cannot be meaningfully developed in open discussions. The function of a guiding tifa such as the China Dream, by virtue of its self-definition as a correct form of words, is to foreclose inquiry and reflection. Yurchak wrote of Party language in the Soviet Union that it generated 'a peculiar paradox': for a population habituated to authoritarian censorship and propaganda, 'although the system's collapse had been unimaginable before it began, it appeared unsurprising when it happened'. ${ }^{20}$ 
The propagation of the China Dream as each individual Chinese citizen's dream is the remedy Xi hopes will prevent a similar collapse of Party rule in China. He is not offering citizens the freedom to discuss what dreams they can realistically achieve in a highly competitive and unequal society under increasing state control. Rather, he is telling them to dream as patriots. When he urged students at Peking University to be patriotic like their May Fourth predecessors, Xi reminded them that 'in present-day China, the essence of patriotism is to uphold the maximal unity of one's love for the country, the Party, and socialism'.

In 1922, Lu Xun likened Chinese society to the unconscious inhabitants of a hermetically sealed 'iron house' 铁屋, walled in by the archaic and obsolete ideas of dynastic rule and wenyanwen, suffocating to death as they slept. Figuring New Culture and May Fourth as attempts to rouse some from their slumber, he asked his friend Qian Xuantong 钱 玄同 whether any good could come of rousing these unfortunate few. The outcome would be only to alert them to the 'agony of irrevocable death' in an indestructible iron house. Qian replied: 'But if a few wake up, you can't say there is no hope of destroying the iron house. ${ }^{21}$

In 2019, Xi's administration intensified its aggressive measures to curtail academic freedoms, force-feed students Xi Jinping Thought, and punish the Party's critics at mainland universities. It also incarcerated more than one million Uyghurs and people from other Muslim ethnicities in China in political re-education camps in Xinjiang. Justifying these actions as necessary for achieving the 'Chinese nation's great rejuvenation' only makes sense if the 'Chinese nation' is merely a synonym for the CCP. In short, the China Dream tifa tells us the Party-state aspires to nothing less than an iron house in perpetuity. 
论坛 


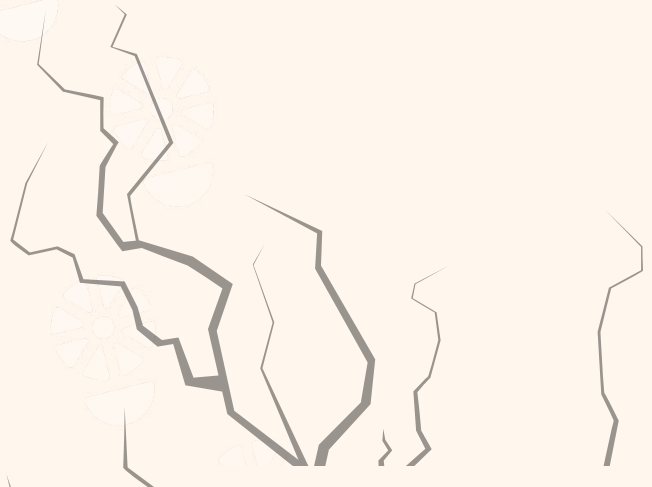

\section{ENFORCING THE DREAM}

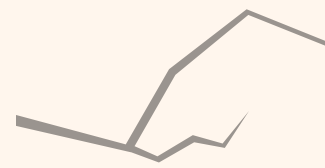

Xi Jinping's War on 'Black and Evil'

- BEN HILLMAN

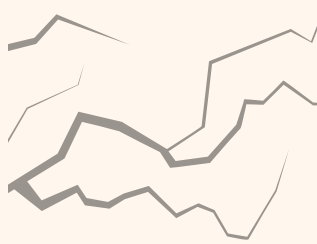

Literary Chinese Textbooks in the PRC

- ESTHER SUNKYUNG KLEIN and VICTOR FONG
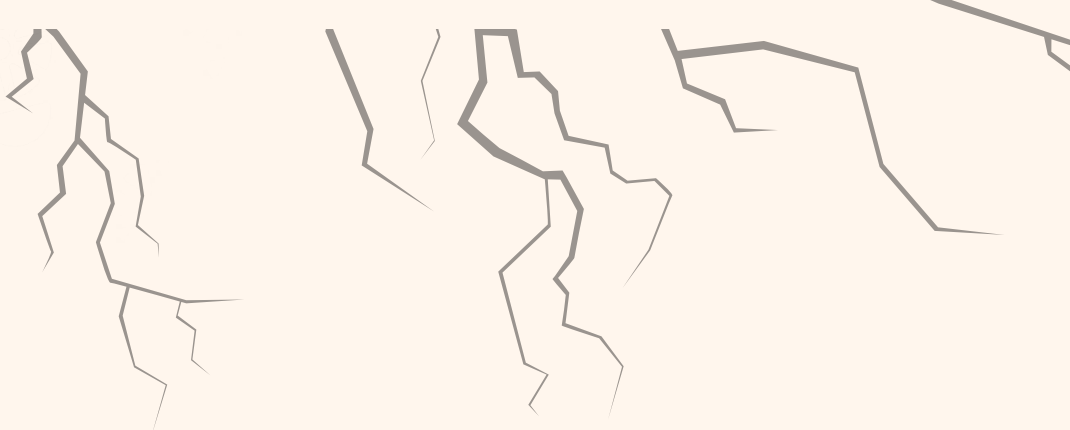


\section{JINPING'S WAR ON
“BLACK AND EVIL’
Ben Hillman}

$\mathrm{T}_{\mathrm{s}}$ HE CHINESE COMMUNIST Party's Sweep Away Black and Eliminate Evil 扫黑除恶 campaign entered its second year in 2019. When it launched in 2018, the three-year campaign promised to take down criminal or 'black society' gangs 黑社会 involved in gambling, prostitution, and extortion, as well as other 'black and evil forces', such as the coercive monopolies of 'sand tyrants' 沙霸 who force construction companies to buy building materials through them at inflated prices, and 'underground police', 地下 执法队 who enforce informal rules in street markets.

Loan sharks and usury 高利贷 are also high on the hit list. Loan sharks charge high interest for fast cash, and loan terms are typically short. Borrowers find themselves in serious trouble if they fail to repay the loans on time. A common loan shark tactic is the 'nude loan' 裸贷, which comes with the condition that borrowers (who are usually young and female) provide the loan shark with nude photos of themselves that will be posted on the Internet in case of default. Law enforcement in the People's Republic of China (PRC) calls such offences 'soft violence' 软暴力. And it can get a lot worse for loan shark victims. According to a local policeman I interviewed in Yunnan province: 


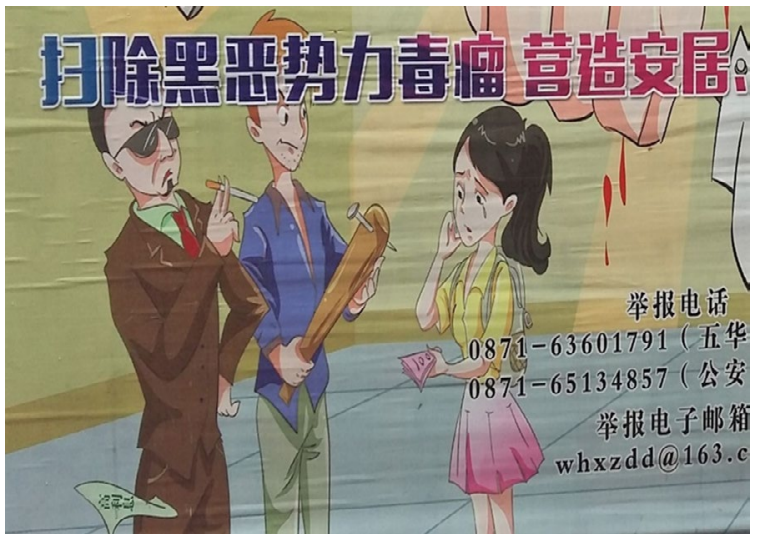

Billboard on Kunming street showing loan sharks. The sign reads: 'Remove the cancer of black and evil forces' and provides hotlines and an email for reporting crimes

Source: Ben Hillman

[G]angs will do anything to terrorise people who owe them money, [including] flushing people's heads in the toilet and making them eat shit. Sometimes they imprison people in a room until they come up with a plan for repayment.

False (illegal) imprisonment is apparently so common that, along with nude loans, it has been specifically identified as one of the 'black and evil' acts to be eradicated in the campaign.

In a Yunnan village I visited in March 2019, locals confirmed the policeman's report, and offered many examples of people who had met sorry fates at the hands of loan sharks. The villagers also confirmed that the
Sweep Away Black and Eliminate Evil campaign was having a good effect. 'The gangs are quiet now', a former township head told me: 'They know this [crackdown] is serious.' The state news agency Xinhua reported that, by the end of March 2019, the campaign had uncovered 14,226 cases of 'black and evil' activity involving 79,018 people. ${ }^{1}$

Sweep Away Black and Eliminate Evil targets not only evil forces 黑恶 势力 within society, but also the 'protective umbrellas' 保护伞 and 'relationship networks' 关系网 that sustain them from within the state governmentofficialsandmembersofthe police force who aid and abet gangsters. Complementing President Xi Jinping's anti-corruption drive, the campaign 
seeks to break up the patronage networks of 'little kingdoms' 小王国 that have evaded previous efforts at eradication. ${ }^{2}$ China's provinces have jockeyed with one another to achieve the highest number of arrests of officials serving as 'protective umbrellas', with regular public announcements about the latest busts. In April 2019, Liaoning province's Office for Discipline Inspection announced that it had investigated and responded to more than 1,000 'black and evil' cases, including some involving 'big fish' such as Ji Hongsheng, former Deputy Chief of Dandong City Public Security Bureau. Ji was sentenced to ten years for helping criminals avoid prosecution. ${ }^{3}$ In the dock, Ji said: 'I thought I was helping out a friend - no big deal. I didn't think it was a crime, but now I regret it.'4

It is a common grievance on the streets of China that well-connected people receive only light punishment when they fall foul of the law. Media attention given to cases such as $\mathrm{Ji}$ Hongsheng's is designed to reassure the public that the Party is determined to root out local corruption and see justice served. A government official told me in March 2019 that the crimebusting element of Sweep Away Black and Eliminate Evil was very popular with ordinary citizens.

But not all elements of the campaign have been popular. In 2019, the campaign's scope expanded to include social disorder 乱. The expanded mandate - revealed in a number of Party documents released throughout the year - is reflected in campaign propaganda across the country. The road sign on the next page is typical of the revised propaganda; it reads: 'Where there is black, sweep it, where there is no black, eliminate evil, and where there is no evil, cure disorder.' Security forces are on notice: there is always someone to catch! Party documents and propaganda suggest that the inclusion of 'disorder' is a natural extension of the campaign and reflects the emphasis on rule of law and China's new social governance systems. Nanjing City, for example, announced in 2019 that it was strengthening its grid-based social governance system to ensure that 'evil forces' - including village, city, and transport 行霸 'tyrants' (for example, taxi and delivery monopolies) — had nowhere to hide. ${ }^{5}$

The spectre of the 'black hand' or 'black and evil forces' draws on a long history of Chinese political and 


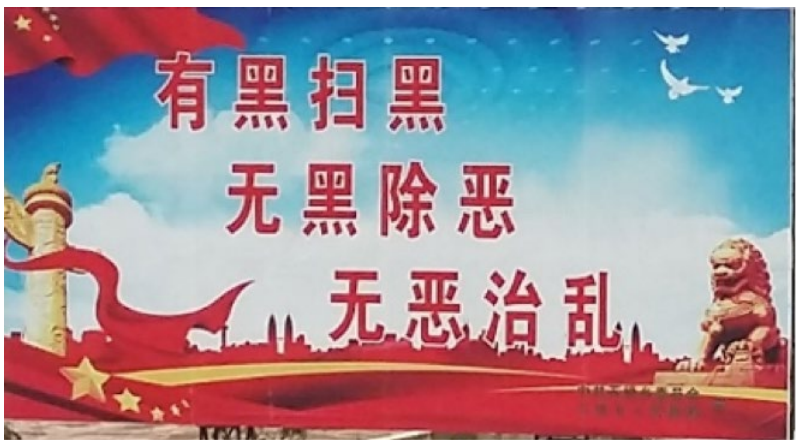

Roadside billboard

in Yunnan Province:

'Where there is black,

sweep it, where there is

no black, eliminate evil,

and where there is no

evil, cure disorder'

Source: Ben Hillman

legal discourse that goes well beyond the sense of 'gangster' or 'miscreant'. The term has been used frequently as shorthand for enemies of the state in Communist Party rhetoric and is now used routinely to dehumanise and delegitimise protestors and dissidents. State media has described the Hong Kong protests of 2019, for example, as being orchestrated by 'black hands' with support from 'foreign black hands'. Protests in China's Tibetan areas a decade ago were similarly characterised. $^{6}$ Another Chinese term frequently used to dehumanise enemies is 'fly' 拍蝇, which routinely appears in Sweep Away Black propaganda. For example, a Shanghai City government notice highlights central party directives to sweep away 'local flies’ 基层 ‘拍蝇' alongside 'black and evil forces and the corrupt'. ${ }^{7}$
With Sweep Away Black and Eliminate Evil campaign committees now firmly established and empowered at all levels of administration, security agencies mobilised, and undesirable types filling police detention centres, the campaign is proving useful for the Party as it continues to tighten its political control over local society. The persistence of 'black and evil forces' provides justification for the expansion of authoritarian social control systems such as surveillance and social credit schemes. The campaign also coincides with a stricter application of 'political checks’ 政审 for college applicants and jobseekers. As a local businesswoman told me: 'Sweep Away Black and Eliminate Evil is the Party's latest initiative to make us more obedient.'

Local party branches are using the campaign to squash dissent. The 
'black hand' label is often associated with dissent in China, and once a 'black hand' has been identified, it is easy for local Party bosses and law enforcement to make arrests under the auspices of Sweep Away Black. I learned of one case in which villagers who complained about an exploitative land deal were swept up and detained after assembling in a large group to protest. In another village, twentythree people were arrested in a single police swoop. When I returned to Yunnan later in 2019, villagers who had previously celebrated the campaign's takedown of gangland activities expressed concern about its mission creep. Some expressed fears that their association with or family ties to someone swept up in the campaign could land them in trouble. Others reported that a young woman had been expelled from a corporate recruitment program because her father had been apprehended by the Sweep Away Black and Eliminate Evil committee. As one villager explained to me:
We worry because someone only needs to report you to the committee for you to be investigated. People have started making false reports against their enemies. It's like the Cultural Revolution.

Sweep Away Black and Eliminate Evil promotes a vision of a safer, fairer, and more harmonious society, but the campaign's broad mandate and its combative revolutionary style has begun to arouse memories of a nightmarish past that post-Mao China was supposed to have left behind. 
$\frac{42}{43}$

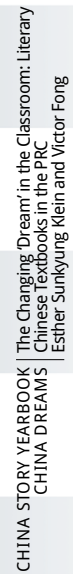




\section{THE CHANGING “DREAM” IN
THE CLASSROOM: LITERARY
CHINESE TEXTBOOKS IN
THE PRC
Esther Sunkyung Klein and Victor Fong}

$\mathrm{N}^{\circ}$

DREAMS ARE MORE powerful or poignant than those a nation imparts to its children. One revealing window into such dreams is a school textbook. On 20 February 2019, an anonymous post on Weibo disclosed that updates were being proposed to the People's Republic of China (PRC) middle-school textbook for literary Chinese, including the removal of the rousing story of Chen She 陳 涉 (d.208 BCE), the peasant leader of a grassroots rebellion against the tottering Qin empire (221-207 BCE). Chen's biography comes from Sima Qian's 司馬遷 (b.145 BCE) Records of the Historian 史記, a classic of Chinese literature as well as a foundational work of history. The current textbook selection narrates Chen's life from his youth until his rise in the rebellion. According to a manual for teachers, it is supposed to 'demonstrate the tremendous power of the first righteous peasant uprising in our country's history' and give students a sense of 'the spirit of struggle underlying the peasants' righteous uprising'. ${ }^{1}$

According to the Weibo source, education authorities plan to replace Chen She's story with an anecdote about Zhou Yafu 周亞夫 (d.143 BCE), an upright and law-abiding general of the Han dynasty (202 BCE-220 CE) whose story is also found in the Records of the Historian. ${ }^{2}$ Since the early 1960s, 


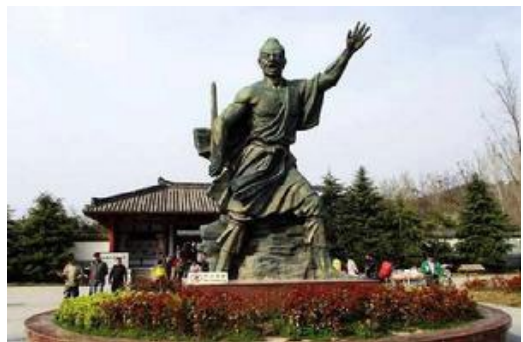

The tomb of Chen She in Hunan province

Source: Baike

generations of mainland Chinese students have learned Chen She's story byheart,whichiswhynewsofitsplanned removal from the latest textbooks astonished the Chinese public.

News outlets reported an outcry on social media. ${ }^{3}$ The new textbook's editor-in-chief told the state-run Global Times that the change was 'a purely academic adjustment' to 'avoid interdisciplinary overlap', since parts of Chen She's story will remain in the history textbooks. Xu Guoqi 徐國琦, Professor of History at the University of Hong Kong, instead interprets the update as an expression of fear: a story that once symbolised the noble cause of (Communist) revolution could be seen today as an encouragement to protest. ${ }^{4}$ We argue further that the change points to a profound shift in the nature of the national 'dreams' being proposed to the younger generation in which heroic revolutionary courage is no longer a priority. What is called for instead is the courage to uphold the system, as expressed by the current Party line of 'ruling the nation in accord with law' 依法治國 (see the China Story Yearbook 2016: Control, Chapter 2 ‘Control by Law’, pp.43-57).

\section{The Political Role of School}

\section{Textbooks in China}

Textbooks present themselves as unbiased sources of knowledge (even though in virtually all nonscientific cases this is blatantly not true). In mainland China, this makes them powerful purveyors of official ideology to susceptible young minds. Robert Weatherley and Coirle Magee have argued that the Chinese Communist Party would consider middle-school history textbooks 'an ideal medium for the transmission of political propaganda', and therefore carefully control the content and how it is framed. ${ }^{5}$ The literary Chinese curriculum can produce an even more powerful effect, since the political subtext is submerged in stories that themselves are inspiring and also linked to a proud cultural heritage. Presented in the context of language learning, 
stories such as these are justly prized and not merely part of a program of flat-footed ideological instruction.

In 1951, when the leading authorised textbook publisher, People's Education Press (PEP), produced the PRC's first middle-school textbooks, they did not include the story of Chen She. At the time, the People's Daily criticised them for failing to present inspiring tales of ancient heroes engaging in the 'glorious Chinese tradition of revolution' that had culminated in the establishment of the 'New China'. It was in this context that, beginning in 1960, PEP included Chen She's story in textbooks. China's youth were instructed to dream of further revolution, with consequences that are now well-known.

The Party-state under President $\mathrm{Xi}$ Jinping is placing ever more importance on the role of textbooks in political messaging. In the past, publishers following the lead of provincial departments of education were allowed to compile local textbooks that took into account regional differences. But since 2017, with the establishment of its National Textbook Commission 國家教材委 員會, the Party-state has started to oversee the compilation of school textbooks. It plans to replace the various current versions with nationally standardised texts by 2020 .

Announcing this news, the Ministry of Education said the new textbooks would 'adhere to the correct political direction ... and fully represent the new political theory, ideology, and strategy of the Party Central Committee with Comrade Xi Jinping at its core'. ${ }^{6}$

\section{The New Party Line and Zhou Yafu's Story}

Since Deng Xiaoping launched his policy of Economic Reform and Opening Up to the outside world in 1978, China's economy has grown tremendously, but so too have economic inequality and official corruption. The pro-democracy protest movement of 1989 began in response to corruption. Both corruption and the perceived inability or unwillingness of China's legal system to deliver justice have also led to other, more local uprisings. Xi Jinping's administration has responded by placing great emphasis on 'rule by law' and a largescale anticorruption campaign (see the China Story Yearbook 2015: Pollution, Chapter 2 'The Fog of Law', pp.67-85 and the China Story Yearbook: Power, 


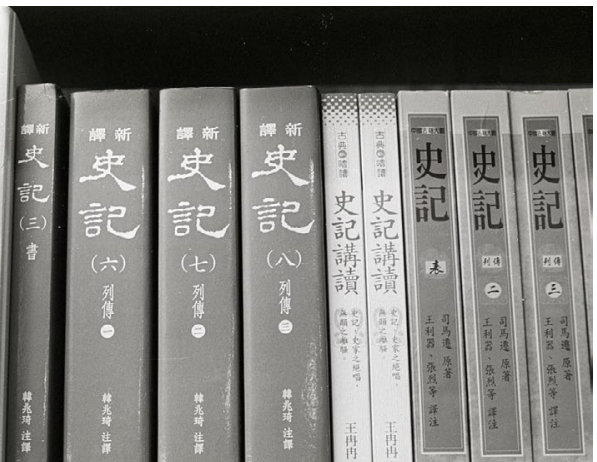

Sima Qian's 司馬僄 (b.145 BCE) Records of the Historian 史記 Source: 命は美しい,

Chapter 1 Forum 'Power Surge: China's New National Supervisory Commission', pp.31-33). The notion of 'ruling the nation in accord with law' has therefore become an important slogan. It is against this background that we interpret the state's discomfort with taking the righteous rebel Chen She as a paradigm, and its preference for the law-abiding Zhou Yafu.

Zhou Yafu, a Han dynasty general, successfully suppressed the Rebellion of the Seven Princes of 154 BCE. Sima Qian characterised him as an upright military man devoted to strict discipline. The anecdote selected for the textbook begins when the emperor orders Zhou and two other generals to set up camps by the border to repel incursions by hostile neighbouring peoples. The emperor himself visits the camps to encourage the troops, with the other two generals immediately welcoming their ruler. At Zhou Yafu's encampment, however, armed sentries greet the emperor's party and allow him in only after he shows his official imperial credentials. This story promotes the notion that things must be done in accordance with the law and echoes Xi's slogan. It also implies that the same rules should apply to everyone, even to the most powerful person in the country - that is, it hints at a dream of full 'rule of law' rather than just rule by laws that do not constrain the rulers themselves. The language of traditional Chinese historiography has always hidden its critical intent between the lines. Whoever chose the Zhou Yafu story as part of the new China Dream continues this tradition, hinting at a version of 'rule of law' that far exceeds what $\mathrm{Xi}$ Jinping would likely endorse. 



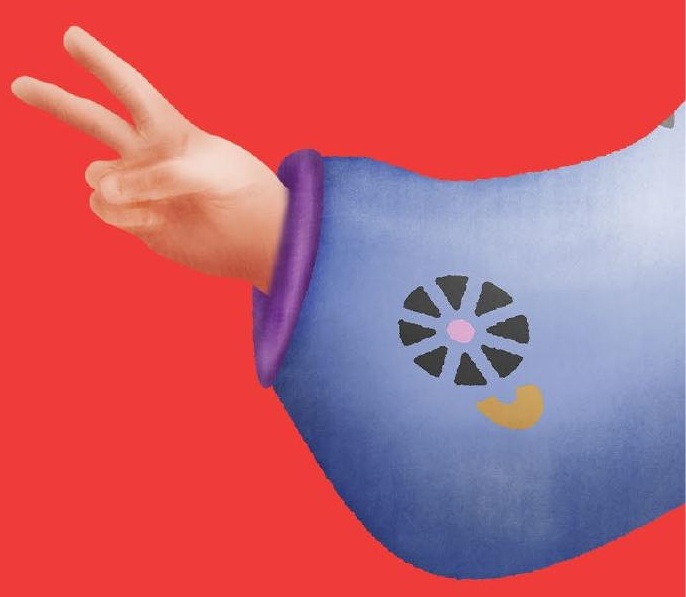




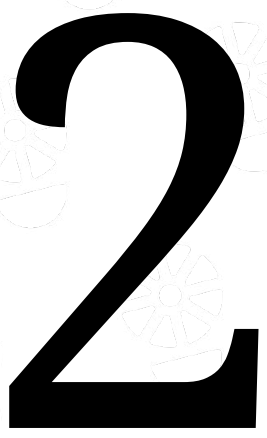




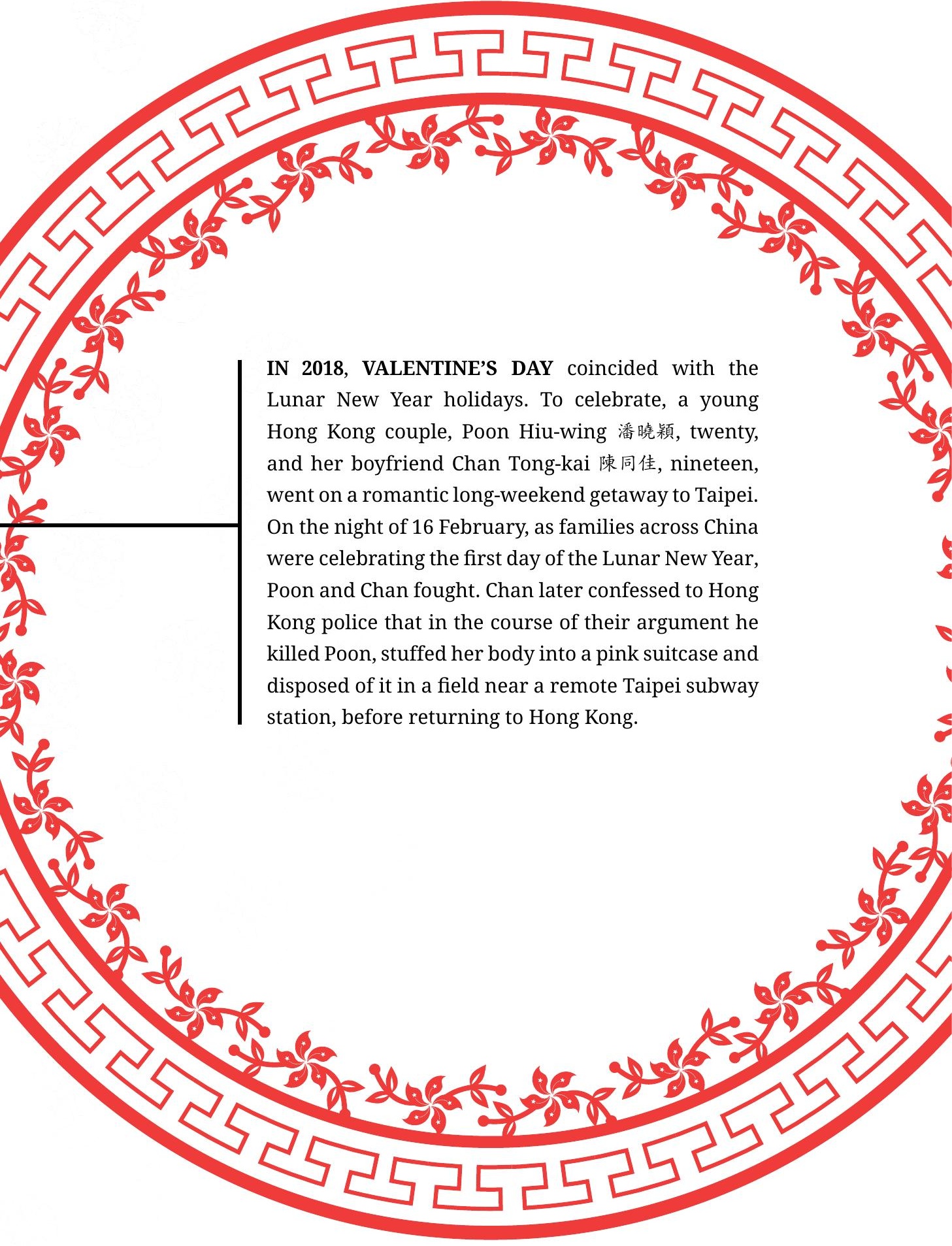




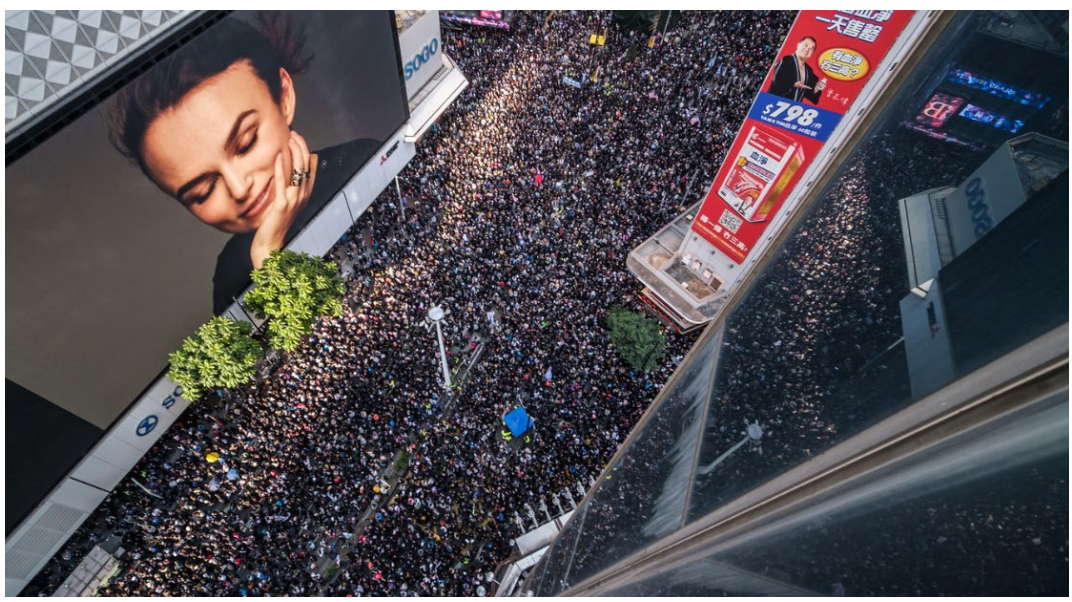

Aerial view of the protests

Source: Studio Incendo, Flickr

No-one could have expected that this tragic incident would lead to the greatest crisis Hong Kong - and possibly the People's Republic of China (PRC) - has faced since 1989, an ongoing crisis that, at the time of writing, shows no signs of fading. But there is a direct path from that hotel room in Taipei in 2018 to tear gas and bullets on the streets of Hong Kong in 2019. Although Chan confessed the murder to police in Hong Kong, his case moved into a legal lacuna. Under Hong Kong law, Chan could not be charged for committing a murder outside Hong Kong and he could only be extradited to a jurisdiction with which Hong Kong had entered into an extradition treaty. Taiwan was not one of those jurisdictions.

Facing the possibility that Poon's murderer would escape justice, Hong Kong's Chief Executive, Carrie Lam Cheng Yuet-ngor 林鄭月娥, proposed a solution that she felt would both address the injustice and please her political masters in Beijing: amending Hong Kong's Fugitive Offenders Ordinance to remove the geographic restrictions so that, provided certain procedural steps were met, fugitives could be extradited to anywhere in the world, including Taiwan — and mainland China. 
At first blush, it appeared to be something of a legal technicality, not the kind of thing to arouse the passions of millions. But the proposal touched a nerve; for the first time, it established a direct link between Hong Kong's justice system - built on the common law principles of an independent judiciary and the separation of powers - and that of the mainland, which is opaque, unpredictable, and ultimately beholden to the Chinese Communist Party. Not since 2003 had the Hong Kong government — with its notorious 'Article 23' national security legislation — attempted to push a policy that was so blatantly in the interests of Beijing, and so contrary to the interests of the people of Hong Kong.

\section{“Fan Song Zhong" 返送中}

The international media covered subsequent events. First came a march of one million Hong Kongers all dressed in white on Sunday, 9 June 2019, in response to which the government announced that the proposal would be proceeding regardless. Tens of thousands of protesters then laid siege to the Legislative Council ('LegCo') building on Wednesday, 12 June, preventing the LegCo from meeting and effectively putting a stop to the proposal; police violently dispersed the protesters using tear gas and rubber bullets. On the following Sunday, 16 June, there was another march, this time of two million Hong Kongers - more than one-quarter of the population - all dressed in black.

Lam seemed surprised that the extradition bill provoked such a visceral response from the Hong Kong populace. She should not have been. Nerves had already been rattled when mainland agents abducted several booksellers from Hong Kong's streets in 2015 and spirited them across the border (see the China Story Yearbook 2016: Control, Chapter 7 Forum 'Control and Resistance in Hong Kong', pp.269-275). It also did not help that the anti-extradition bill cause aligned the interests of Hong Kong's pandemocrats, who feared political persecution, with those of the pro-Beijing 
elite, whose business dealings on the mainland left them the most exposed of all to the risks of the extradition law. More than that, the proposal also triggered anxiety about deeper issues of identity.

In the past, Hong Kong had distinguished itself on the basis of wealth. For decades, its people were rich compared with those in China, which from the late 1970s, began struggling to lift itself out of poverty. However, since the handover from the United Kingdom to the PRC in 1997, as Hong Kong's economy drifted and China's boomed, that distinction failed to hold. Hong Kongers replaced their pride in material success with pride in 'Hong Kong Core Values' - those rights and freedoms that distinguish life in Hong Kong from life in the rest of China. The concept of Hong Kong Core Values was first articulated by a group of pro-democracy scholars and politicians in 2004, initially as an expression of alarm that these values were being lost. However, the concept was soon coopted by the government and more widely across Hong Kong society to articulate Hong Kong's competitive advantage over the rest of China, and indeed much of Asia. Hong Kong Core Values include clean, corruption-free government, a lively and unfettered media, freedom to criticise the government, rule of law and due process, an independent judiciary, and, of course, the right to protest. Hong Kong Core Values became the answer to the question: 'What does it mean to be a Hong Konger?'

The proposed extradition law, which would have breached the legal firewall between Hong Kong and the mainland, was seen as another attack on these core values. The protesters on Hong Kong's streets were protesting against not just a theoretical risk of extradition to the opaque mainland criminal justice system, but also a threat to their very identity as Hong Kongers. And, by taking to the streets, they were expressing their dissatisfaction by exercising their key rights and freedoms. Their protest became a performance of identity.

The protesters' initial demand was summed up in a three-character slogan: 'Fan song zhong!' A direct translation would be 'Oppose sending [accused criminals] to China', but song zhong 送中 is a homophone for 
送终, meaning 'to see off a dying relative'. (It is also, incidentally, a homophone for the phrase 送鐘 'to give a clock', which is why the Chinese consider a clock an unlucky gift as it in effect wishes death on the recipient.) The slogan thus could be understood to mean 'Oppose sending us to our death' - whether by extradition to China or through the death of civil liberties in Hong Kong.

It was unfortunate that, some weeks into the protests, Lam turned to mortality-tinged metaphors when she announced that the extradition bill would not be proceeding. In her English statement to the press, she said bluntly: 'The bill is dead.' In Chinese, she said the bill 'shou zhong zheng qin' 㗲终正寝, meaning it had 'died a natural death from old age in its bed'. Commentators were quick to point out this did not reflect the true state of affairs for a bill that had more accurately been killed by the protests.

It mattered little to the protesters that Lam had suspended the bill indefinitely. This was in part because they demanded its formal withdrawal and did not trust Lam's assurances that the suspended bill would not be revived. In the meantime, protesters' demands had broadened to include, among other matters, an independent inquiry into police behaviour as well as universal suffrage. The former demand arose from numerous incidents that had damaged public trust in the police: beyond the unrestrained use by police of tear gas, rubber bullets, and other 'less lethal' weaponry on

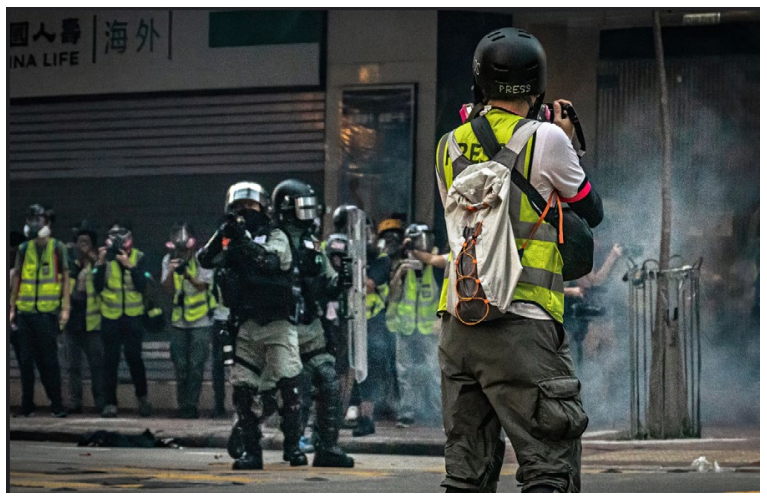

Tension between police and protesters on the streets of Hong Kong 
the citizenry, Hong Kongers were particularly incensed when Triad gang members attacked young protesters and other commuters at Yuen Long Mass Transit Railway (MTR) station as they returned home after a protest on the night of 21 July, savagely beating them with bamboo canes. Police were slow to respond and were later photographed casually chatting with the armed thugs. The latter demand was the unfinished business of 2014's Umbrella Movement. The contrast between that utopian movement and the dystopia of the 2019 protests marked this movement as something more desperate.

\section{From Dream to Nightmare}

Many recall the 'occupied' sites of the Umbrella Movement as mini-utopias that reflected the hopes of the movement itself, which agitated for a 'more perfect' democracy for Hong Kong. Rows of rainbow-coloured tents lined the roads while cultural expression flourished: banners, posters, chalk drawings, and sculptures adorned the sites. Thousands flocked with their families to visit on sunny weekends, when the mood felt like a community arts festival, with movie screenings, musical performances, and arts and crafts activities. The Umbrella Movement became performative of the kind of society it hoped Hong Kong would become - a peaceful, self-regulating community, built on mutual support and sharing, a gift economy of donated goods and services, all of which were a far cry from the self-interested rampant capitalism for which Hong Kong was known.

Like the Umbrella Movement, the 2019 protest movement had a lively and prolific visual culture. Vast amounts of graphics, cartoons, posters, and memes were generated, many responding to events on a daily basis. These circulated online and were also posted on 'Lennon Walls' — sites for public expression that expanded from one single site in Admiralty during the Umbrella Movement to multiple sites blossoming across the city throughout the year. However, in 2019, the tone changed. Far from the 


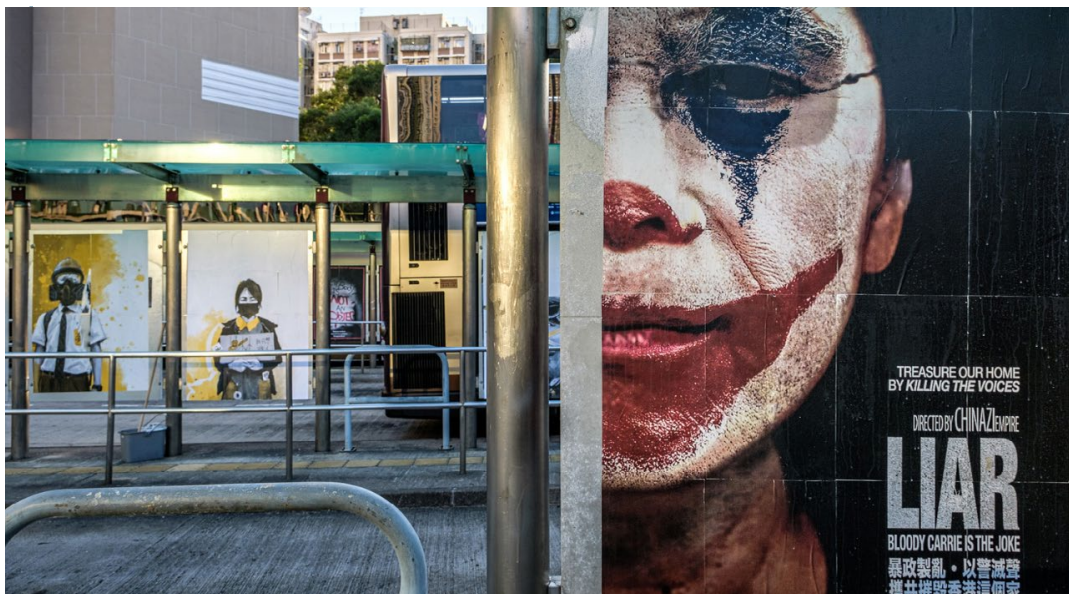

Protest posters at bus stops

Source: Studio Incendo, Flickr

utopian ideals of the Umbrella Movement, demonstrators in 2019 were fighting against their city sliding into what they saw as a dystopian nightmare of police brutality, arbitrary detention, and extrajudicial punishment. Not only was this something they feared if extradition to the mainland became a reality; they also saw it increasingly unfolding on the streets of their own city, as police began using arrest as a method of crowd control, with innocent passers-by arrested for 'unlawful assembly', and many arrestees complaining of beatings and other mistreatment at the hands of police while in detention. The initially peaceful protest movement became mired in an escalating cycle of violence; police deployed tear gas on the streets of Hong Kong every week for months. Police also used rubber bullets, pepper pellets, beanbag rounds, water cannons loaded with 'tear water' (a skin irritant), an indelible blue dye to help them locate the protesters they had hit, and - finally — live ammunition. Protesters responded in kind, arming themselves with clubs, shields, and slingshots, and throwing bricks and petrol bombs. 


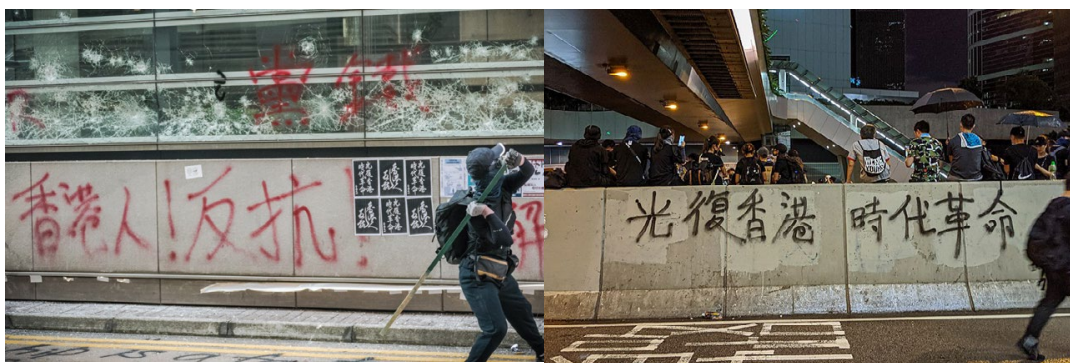

'Hong Kongers, resist!' (left); 'Restore Hong Kong, Revolution of Our Times!' (right)

Source: Studio Incendo, Flickr

The darker shadows of history have hung heavily over the 2019 protests. These are the shadows of Hong Kong's 1967 riots — which lasted longer, and featured much more violence and greater loss of life - and 1989's Tiananmen Square protests and 3-4 June crackdown, the ghosts of which were summoned by Beijing in mid-August when it conspicuously stationed People's Armed Police forces in a sports arena across the border in Shenzhen (see Chapter 8 'Hong Kong and the Tiananmen Playbook', pp.223-235). The troops were shown on television carrying out crowd control exercises in which the police shouted in Cantonese and their antagonists were attired strikingly like the Hong Kong protesters.

The protesters' slogans evolved to reflect the darkening mood. In the early stages of the movement, the rallying cry was 'Hong Kongers, add oil!'香港人加油, reflecting the identity-centric nature of the movement. After Lam used emergency powers to implement a ban on face masks on 4 October, that chant became 'Hong Kongers, resist!'香港人反抗. And, following the death on 8 November of a young student protester who fell from a multistorey car park, reportedly while trying to evade police, the chants became 'Hong Kongers, revenge!' 香港人報仇.

To describe their protest strategy, the protesters adopted the slogan: 'Be water!' The Umbrella Movement had followed the 'occupation' logic of worldwide protest movements such as the Occupy Wall Street movement. This time around, Hong Kong's protesters took their inspiration from a 
source closer to home: local hero and kung-fu-movie star Bruce Lee, who famously advised: 'Be water!' The protesters adopted a highly mobile, agile style of protest, flowing like water. A rally would turn into a march; a march would begin in one direction and abruptly change to another direction; and protesters carried out targeted 'wildcat' occupations of roads or buildings. With no entrenched positions and an unpredictable and mobile presence, the protesters effectively rendered themselves immune to clearance and arrest. If they met police resistance, they would immediately disperse - flowing away like water.

Another notable and hugely popular slogan has been: 'Restore Hong Kong, revolution of our times!' 光復香港, 時代革命. It was originally the campaign slogan of Hong Kong independence advocate Edward Leung Tinkei 梁天琦 in a January 2016 LegCo by-election. Leung was subsequently jailed for his role in the Mong Kok 'Fishball Riot' of 2016 (see the China Story Yearbook 2016: Control, Chapter 7 Forum 'Control and Resistance in Hong Kong', pp.270). In 2019, the slogan became a rallying cry as a more radical and political expression of Hong Kong identity. The protestors began to use the slogan around the same time they began to target the symbols of PRC state power in Hong Kong: it was graffitied on the walls of the LegCo when that building was stormed by protesters on 1 July, and was first noticeably taken up as a rallying cry by the crowds on the night of 21 July, when protesters attacked and vandalised the Liaison Office of the Central People's Government 中聯辦, Beijing's official representative office in Hong Kong. All of these actions can be seen as part of the struggle for what political scientist Dr Brian C.H. Fong 方志恆 calls the 'stateless nation' of Hong Kong. ${ }^{1}$ Fong argues that Hong Kong - like Quebec, Catalonia, and Kurdistan - is a nation trying to establish its autonomy under the rule of a strong centralist state.

Nations - or 'imagined communities' as theorised by Benedict Anderson - are built just as much with politics as with cultural moments or icons, and the 2019 protest movement has also provided plenty of those. Private chat groups in messaging apps such as Telegram, as well as the 
online forum LIHKG (lihkg.com), a local Hong Kong website operating a low-fi discussion board, have provided means of collective communication and discussion beyond official control. In addition to the wide proliferation of strikingly creative and sometimes darkly humorous artwork, posters and slogans have often made use of the Cantonese language - a key aspect of Hong Kong identity. For example, when a police officer swore at a journalist 'Gei nei lou mou!' 記你老母 (roughly, 'Journalist, your Mum!'), the phrase was taken up as a protest slogan and weapon of political satire. In another example of the creation of national cultural symbols, a pseudonymous local Hong Kong composer wrote a song, 'Glory to Hong Kong' 願榮光歸香港, that many called Hong Kong's 'national anthem'. With lyrics posted and workshopped on LIHKG, the song has a stirring, martial feel. Within a week or two of the song making its first appearance online, protesters and sympathisers sang it at rallies, soccer matches, and at pop-up protests in shopping malls.

The online forums and chat groups also enabled a protest movement that some have referred to as 'leaderless' - and others have called 'leaderful'. Unlike the Umbrella Movement, the 2019 protest movement had no discernible leaders, with everyone contributing what they were willing and able in a networked 'hive mind' of activists, operating in the virtual world and on the ground during protests. This was partly an effective protest strategy and partly driven by necessity - few were willing to risk being a visible leader, knowing that many of the Umbrella Movement leaders had been jailed for their roles in those protests.

\section{'Lawfare' Continues}

The Hong Kong government's aggressive prosecution and jailing of Umbrella Movement leaders formed part of a campaign of what I called 'lawfare' in the 2017 edition of this Yearbook (see the China Story Yearbook 2017: Prosperity, Chapter 9 'Prosperity and Freedom: Hong Kong's Dilemma', pp.295-307). Lawfare is the use of Hong Kong's legal system 


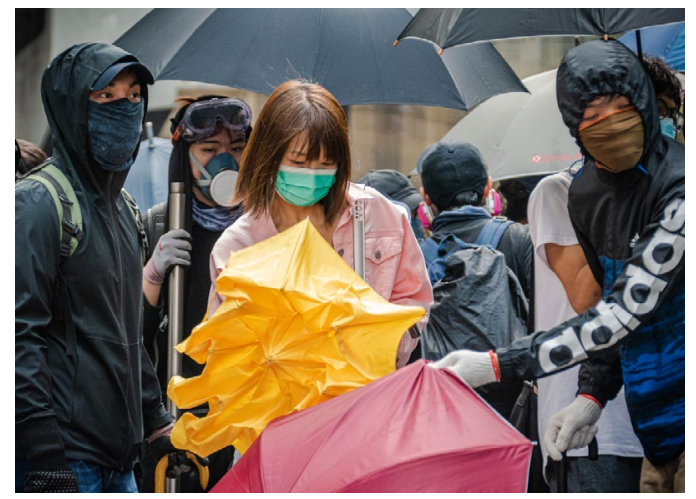

Protesters wearing face masks Source: Studio Incendo, Flickr to manage or silence political opponents and/or achieve political objectives. The lawfare campaign has been politically astute, as it enables the authorities to appeal to the need to uphold Hong Kong's rule of law universally recognised as a Hong Kong Core

Value - while using that same legal system to target the actions of dissenting politicians and activists.

In 2019, the Hong Kong government pursued the ongoing lawfare campaign with renewed vigour in response to the ongoing protests. The Umbrella Movement ended after taxi, minibus, and tour bus companies who claimed their businesses had been affected by the road closures obtained injunctions in the Hong Kong courts requiring the roads to be cleared. Injunctions were weaponised against protests again in 2019. In October and November, Hong Kong courts, at the request of the government, granted injunctions to bar the public from discussing online the use of violence against persons or property, to prevent the disclosure of personal information or photographs of police officers and their families, to prohibit the public from inspecting the registry of voters, and to stop people damaging or obstructing the residences of police. What is more, Lam invoked emergency powers not used since the oil crisis of 1973 to bypass the LegCo and introduce a new law banning the wearing of face masks a law that Hong Kong's High Court declared unconstitutional in late November. The day after the ruling, a spokesman for China's National People's Congress (NPC) said only the NPC had the right to make such a judgement - a comment that threw Hong Kong's legal community into 
disarray as it appeared to repudiate the entire separation of powers doctrine on which Hong Kong's common law legal system is based. At the time of writing, the NPC has not made any further statements on the subject and the Hong Kong government is in the process of appealing the decision in the courts.

Meanwhile, police used mass arrests as a crowd control tool. As with the Umbrella Movement, we should expect aggressive prosecutions of those arrested, and heavy sentences pursued by prosecutors in a process that will be dragged out over years, calculated to wear down the opposition and tie up their leaders and supporters in the courts.

\section{Hong Kong in the World}

At the same time, Beijing has sought to impose its narrative on the events in Hong Kong, both inside China and globally. From the beginning of the protests in June, Beijing's spokespeople blamed the protests on 'foreign interference'. In mid-July, after the protesters attacked the central government Liaison Office, Beijing began referring to the protesters as 'separatists' and said the protests were an attempted 'colour revolution';

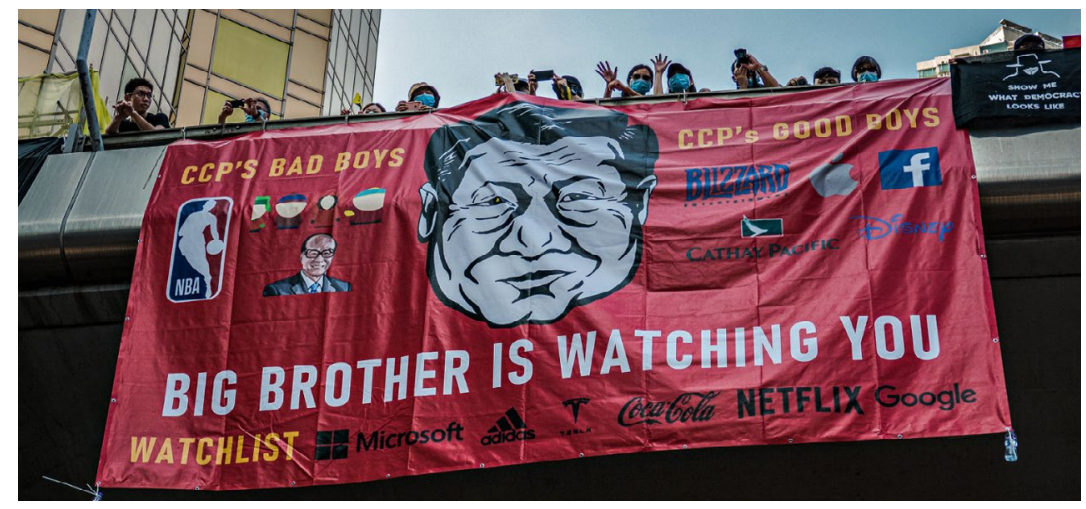

Foreign companies and prominent individuals are becoming accustomed to dealing with Chinese efforts to police their speech on a growing list of 'sensitive' topics

Source: Studio Incendo, Flickr 
and, from August, as protests took a more violent turn, they equated the movement with 'terrorism' - a chilling description given the same charge has been used as the basis for the internment of Xinjiang's Uyghur population.

Through a propaganda push in official state media as well as by manipulating the conversation on social media inside China's 'Great Firewall', Beijing has ensured that domestic sentiment is hostile to the Hong Kong protests. Attacks on mainlanders, such as an incident in which two mainlanders suspected of being PRC agents during a protest at Hong Kong Airport were detained and beaten by protesters, were given prominence in mainland media coverage, further stoking anger there. This hostility spilled on to university campuses and streets worldwide, as pro-China supporters clashed with Hong Kong protesters, often encouraged - if not organised - by Beijing's diplomatic representatives abroad, one of whom lauded the 'patriotism' of the pro-China demonstrators following clashes at the University of Queensland (see Chapter 9 'Campus Conundrums: Clashes and Collaborations', pp.255-267).

The pro-China protesters often sought to prevent others exercising their freedom of speech in relation to Hong Kong, or other issues relating to China, on foreign soil. Twitter and Facebook identified and terminated hundreds of accounts that Twitter called part of a 'coordinated statebacked operation' that was 'deliberately and specifically attempting to sow political discord in Hong Kong'. Twitter also said it would no longer accept advertising by 'state-controlled news media entities' after PRC news outlets extensively advertised anti-Hong Kong messages on the platform.

Foreign companies and prominent individuals are becoming accustomed to dealing with Chinese efforts to police their speech on a growing list of 'sensitive' topics, from the 'three Ts' (Tibet, Taiwan, and Tiananmen) to Xinjiang and the South China Sea. This year, Hong Kong joined that list of sensitive topics. Beijing pressured Hong Kong businesses to 'take a stand' 表個態 — to publicly support Carrie Lam's government and fire employees who participated in the protests. The Hong Kong-based 
airline Cathay Pacific's CEO Rupert Hogg and a key deputy were forced to resign in August 2019 under pressure from Beijing after it was discovered that some of Cathay's staff had been involved in the protests or had simply voiced messages of support. In the same week, following the publication of a crowd-funded advertisement supporting the demonstrations in the name of 'a group of Big Four accounting firm employees', the Global Times called on the Big Four to 'fire employees found to have the wrong stance on the current Hong Kong situation'.

Companies, cowed by fear of provoking the Chinese government or the Chinese consumer - believe if they do not self-censor, Beijing will quickly make its displeasure known, with serious financial consequences. One week in October saw four different examples of this:

- Darrel Morey, Manager of the Houston Rockets NBA basketball team, tweeted the Hong Kong protesters' international rallying cry: 'Fight for freedom; stand with Hong Kong.' He quickly deleted the tweet, but not before it was caught by the Beijing outrage machine and blown into an international incident. The NBA initially rebuked, but then stood behind, Morey, in the face of a China-wide government-led boycott of the NBA, which included cancelling all match broadcasts and withdrawing merchandise from sale.

- Video game company Blizzard (a subsidiary of American gaming giant Activision Blizzard, in which PRC Internet titan Tencent owns a five percent stake) penalised a Hong Kong player who shouted the protest slogan 'Restore Hong Kong, revolution of our times!' during a video game livestream.

- Apple withdrew from sale on its App Store the 'HKMaps' app after complaints from China. The app revealed the locations of Hong Kong police in real time.

- Jeweller Tiffany \& Co. withdrew an advertisement that showed a model covering one eye. This resembled the 'covered eye' gesture adopted by Hong Kong protesters after a young female first-aid provider was shot in the eye and blinded by a police beanbag round. 
All of these developments heightened international awareness of the impact of President Xi Jinping's ambitious program to extend China's global influence. The Hong Kong protesters seemed to be at the vanguard of what author Richard McGregor has called the 'backlash' against Xi's ambitions for a global China Dream. ${ }^{2}$

Another example of that backlash came when the US Congress enacted the Hong Kong

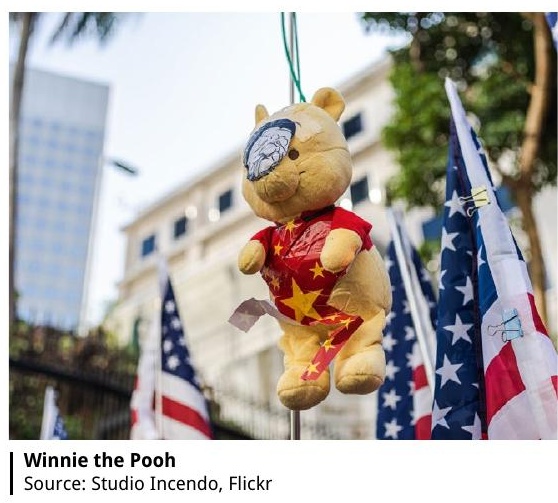
Human Rights and Democracy Act in a rare display of bipartisanship; the bill had sponsors from both sides of the aisle and was passed unanimously by the Senate. President Donald Trump signed the bill into law in November. The Act provides for sanctions against individuals suppressing human rights and freedoms in Hong Kong and, importantly, creates a mechanism whereby the Secretary of State will need to issue an annual certification of Hong Kong's autonomy, thereby ensuring the issue of Hong Kong will be raised annually in Congress. China was predictably incensed by the Act, which it said amounted to interference in its internal affairs, and retaliated with sanctions on a number of US-based nongovernmental organisations that it said were fomenting the Hong Kong protests.

\section{The Silent Majority Speaks}

As the protests raged on - with increasing vandalism, violence, and disruption to daily life - Carrie Lam and the pro-Beijing politicians in Hong Kong spoke of a 'Silent Majority’: patriotic Hong Kongers who opposed the protests but were afraid to speak out. The district council elections, on 24 November, would give them a chance to speak. The election was seen as a referendum pitting the protest movement against Lam's government 
and Beijing. And speak the people did, although they did not say what Lam and Beijing had hoped they would.

In a day that saw Hong Kong's highest ever election turnout - with 2.9 million people, representing seventy-one percent of eligible voters, casting a vote - the pan-democrats won in a landslide. Pan-democrat candidates won 385 seats; pro-Beijing ('establishment', pro-government) candidates won only fifty-nine seats; eight seats went to independents. ${ }^{3}$ (For comparison, in the 2015 district council elections, pan-democrats won 126 seats, pro-Beijing candidates won 298 seats, and independents won seven seats.) Pan-democrats won control of seventeen of the eighteen district councils; previously, they had controlled none. (For the remaining council, Outer Islands, pan-democrats won a majority of the seats open to popular vote but pro-Beijing parties retained control due to ex officio positions given to rural chiefs.) The results were unequivocal: a clear majority of Hong Kongers supported the protest movement and placed the blame for the ongoing chaos at the feet of Lam, her government, and the pro-Beijing politicians who support her.

Beyond this objective and indisputable measure of public opinion, the district councils themselves enjoy little real power. However, the pandemocrats' win came with a bonus prize: control of the district councils effectively entitles them to appoint a 117-person bloc of representatives to the 1,200-member Chief Executive Election Committee, which will select the next Chief Executive, in 2022.

\section{China in Hong Kong}

The district council elections ushered in a period of relative calm, but it is unlikely the protests have ended entirely. Indeed, it is difficult not to wonder whether this represents a 'new normal' for Hong Kong: a constant background level of discontent and civil unrest occasionally bursting into violent confrontation. Meanwhile, Hong Kong sank into recession in the 


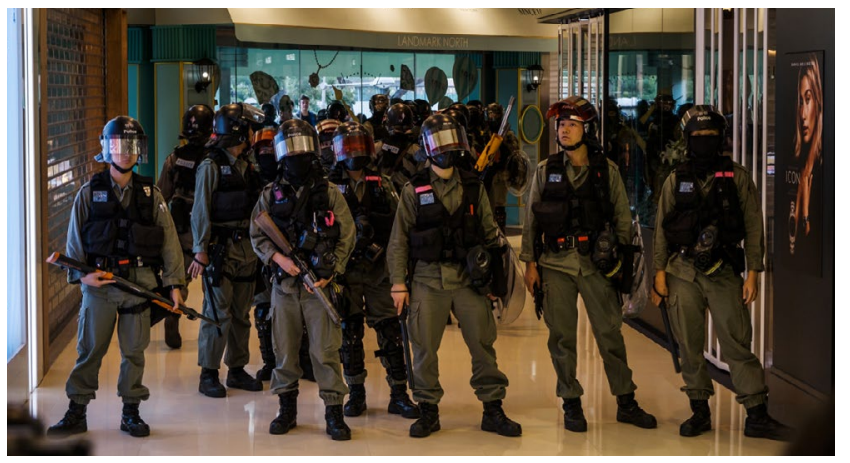

Closed shop fronts

during the protests

Source: Studio Incendo,

third quarter of 2019, with the economy shrinking 3.2 percent. Retail and hospitality industries were particularly hard hit, with retail sales in August 2019 falling twenty-three percent from a year earlier to the worst level on record, and visitor numbers fell thirty-seven percent year-on-year for the third quarter of 2019.

Some have openly begun to speculate about a 'Belfastisation' of Hong Kong, as some among the protesters pushed closer to extremism (including with more violent attacks on police and government targets), deepening social and political divisions. All of this might suit Beijing's interests in demonstrating to the rest of China the 'chaos' unleashed by popular prodemocracy movements, emphasising the need for the steadying hand of the Party, while justifying tightened control over Hong Kong.

The Party's Fourth Plenum meeting in October confirmed that Beijing intends to use all of the tools of China's state power necessary to bring Hong Kong to heel: the propaganda campaign, pressure on businesses in Hong Kong and abroad to toe the party line, demands that Hong Kong government leaders and the civil service demonstrate their patriotism and loyalty to Beijing, with appointments closely scrutinised for political acceptability, the promotion of 'patriotic education', and extensive United Front activities. The year 2019 will go down as the one that defined posthandover Hong Kong; perhaps it will be remembered as the last year of Hong Kong as it once was. 
论坛 

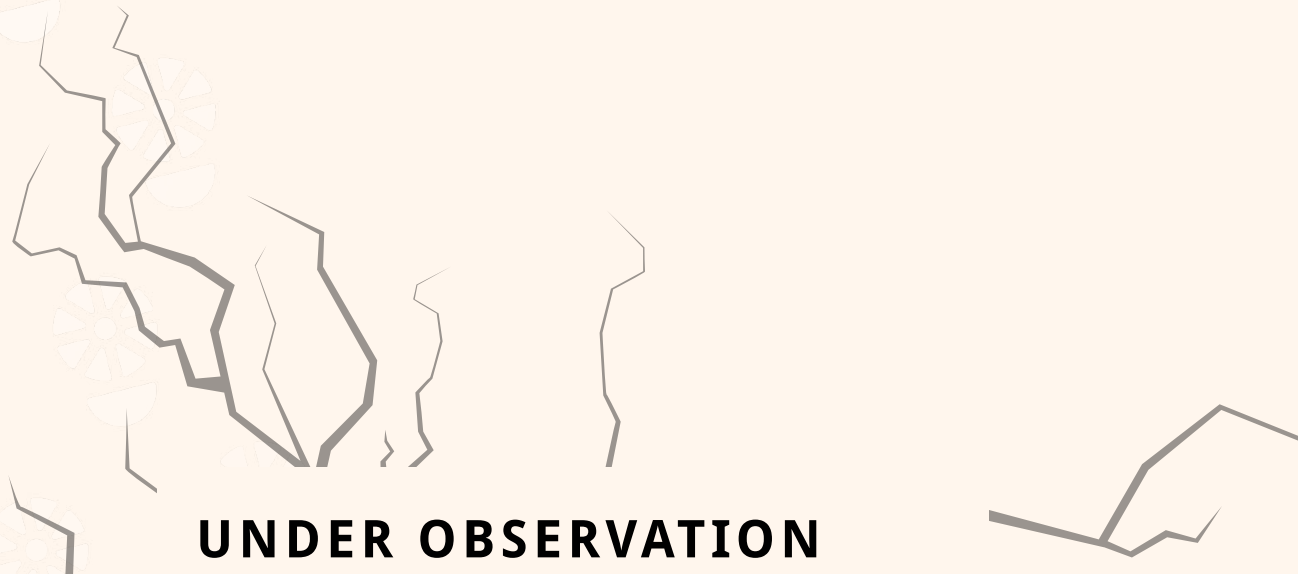

Legalism and the Social Credit System - SAMUEL J. PARSONS

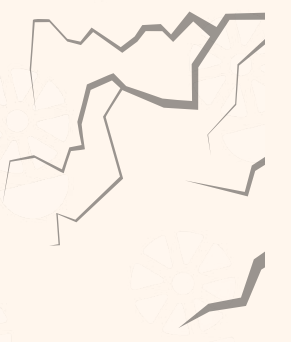

'Evil Cults' and Holy Writ

- BENJAMIN PENNY
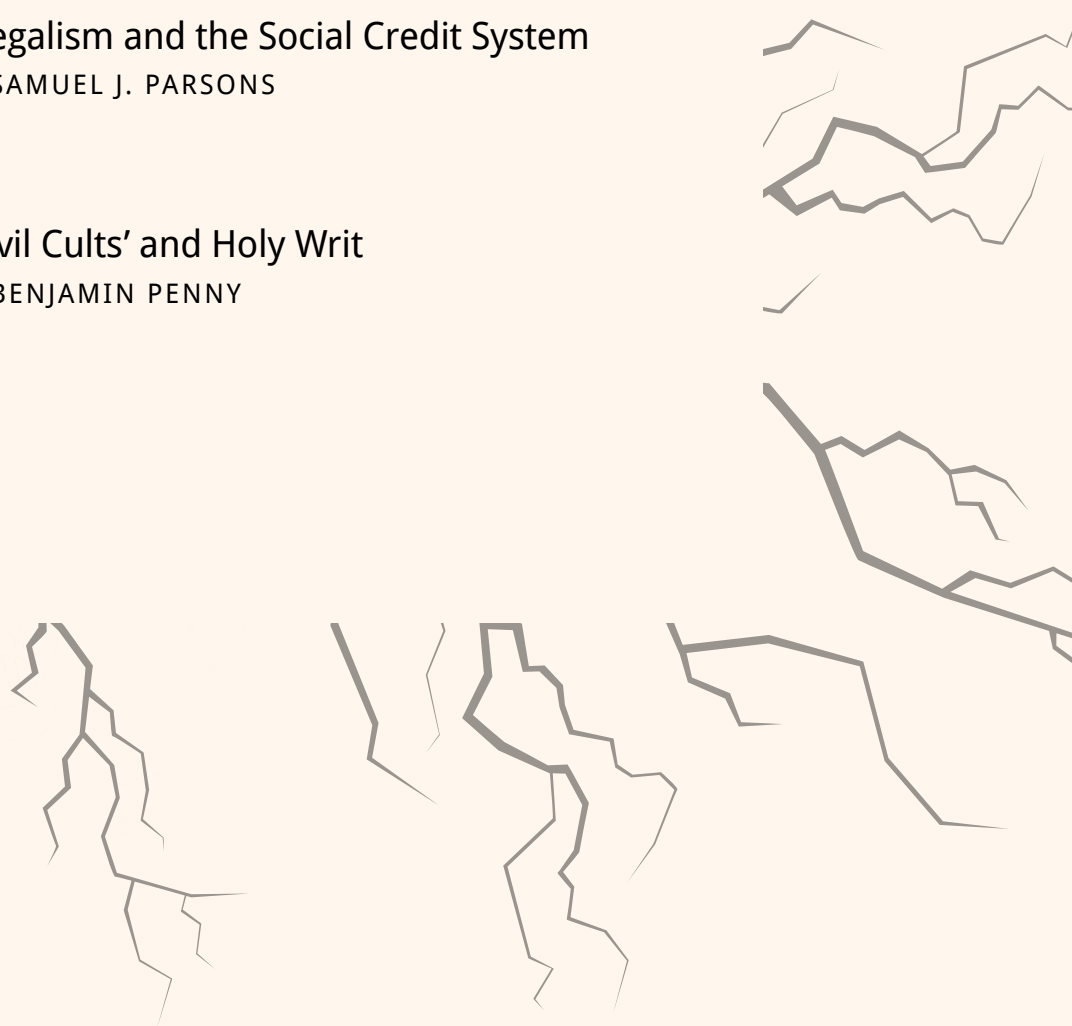


\section{LEGALISM AND THE SOCIAL
CREDIT SYSTEM
Samuel J. Parsons}

TN EARLY NOVEMBER 2019, The SCS consists of several Smartisen CEO Luo Yonghao independent trials - commercial 罗永浩 received a ruling from a and governmental - united by court in Danyang that he had been common characteristics. All SCSs added to a national database of discredited individuals. Due to his large debt, Luo now faces restrictions on travel, finance, luxury spending, and educational opportunities for his children. A similar story applies to 15 million other citizens of the People's Republic of China (PRC) who have run afoul of its recent crackdown on behaviour it deems unsociable. A similar fate awaits those who score poorly in the emerging Social Credit Systems (SCSs). These social sanctions form part of the push by the Chinese Communist Party (CCP) to encourage good behaviour and honesty among the country's immense citizenry using emerging technologies. operate through assigning a social credit score to individuals, which is altered according to their behaviour. Actions that can lower your score range from fraudulent dealings to jaywalking and religious association; those that can raise it are charitable acts, prompt repayment of loans, and good familial conduct. Punishments vary from restrictions on travel and employment to public shaming, while rewards include preferential access to government services and tax deductions. The SCS is not a monolithic enterprise, but an evolving series of localised trials loosely guided by governmental memorandums. 


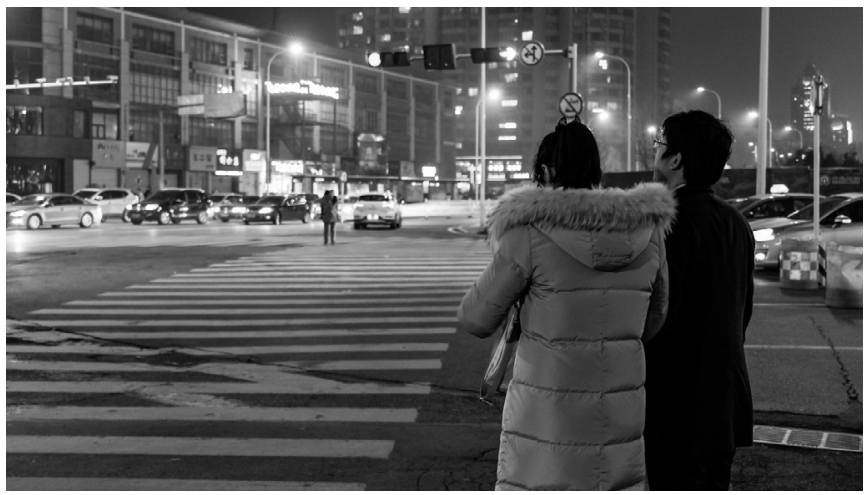

There have been more than forty trials, all with their own goals, variations on the system, rewards, and punishments.

When then secretary-general Jiang Zemin first proposed the SCS in 2002, it was presented as a method to increase the 'trustworthiness' 守 信 of financial actors. ${ }^{1}$ By 2014, it had evolved into a general method of social control. The fragmentary network of trials and experiments that makes up the SCS today shares a common aim: the instilling of behavioural codes, backed by rewards and punishments, which promote 'self-governance' by citizens. SCS, in its use of big data, artificial intelligence (AI), and sophisticated surveillance, including of all online activity, takes on a high-tech guise. But the scheme's philosophical roots lie deep in Chinese history.

\section{The Doctrine of Legalism}

The ancient philosophical school of legalism 法家 arose in the chaos of the Warring States period from 475 to $221 \mathrm{BCE}$. The legalists sought peace and stability through a regime of neartotalitarian social control based on the principles of $f a$ 法 (law), shu 术 (management), and shi 势 (power). By combining these three concepts with an extensive system of mutual surveillance, a ruler could effectively dominate his empire without needing to leave his palace.

The central pillar of this system is $f a$ : the use of harsh penal law as a tool of absolute domination. With certain caveats, its application was to be universal, with the exception of the ruler himself, so that 'the highest minister cannot escape' and 'the 
lowest farmer' would 'not be passed over' ${ }^{2}$ Legalists advised rulers to tailor this legal code to encourage behaviour that would meet the needs of the state. They suggested implementing a set of rewards and punishments (the 'two handles' of government) that would exploit people's tendency to pursue pleasure and avoid pain. Fear, it was thought, was a greater motivator than pleasure, so punishments should be disproportionately harsh compared with the crime committed, and rewards benign. To enhance enforcement, people were grouped into communal units held mutually responsible for any crimes committed by any of their number. ${ }^{3}$

The legalists paid special attention to ministers and officials. The ruler relied on his advisors but was vulnerable to deceit or even usurpation. This is where shu came in; it was a system of 'names and tallies' 姓名 by which to assess ministerial performance. The 'name' was a specific task or position and the 'tally' a record of actions and results. If they matched, a minister would be rewarded and promoted; if not, he would be punished severely. By ignoring what was said and focusing on what was done, the ruler could no longer be deceived. ${ }^{4}$

While $f a$ and shu were ingenious methods of social control, they counted for little if the ruler could not enforce them. Hence the ruler must also have shi: effective power. Both $f a$ and shu rely on the rulers' ability to monitor the actions of individuals and dole out the appropriate rewards and punishments. The legalists thus advocated a system of mass surveillance to guarantee that no good deed went unrewarded and no bad deed unpunished. ${ }^{5}$

Legalism rose to prominence under Qin Shi Huang, who conquered the Warring States and unified China in 221 BCE. Though the Qin dynasty lasted only fifteen years, the state bureaucracy and legal system it produced survived relatively unchanged throughout the history of Imperial China, despite the adoption of Confucianism as the official state ideology.

\section{Similarities with the Social Credit System}

Both this legalist philosophy and the rationale underlying the SCSs espouse a universal set of rules backed by a 


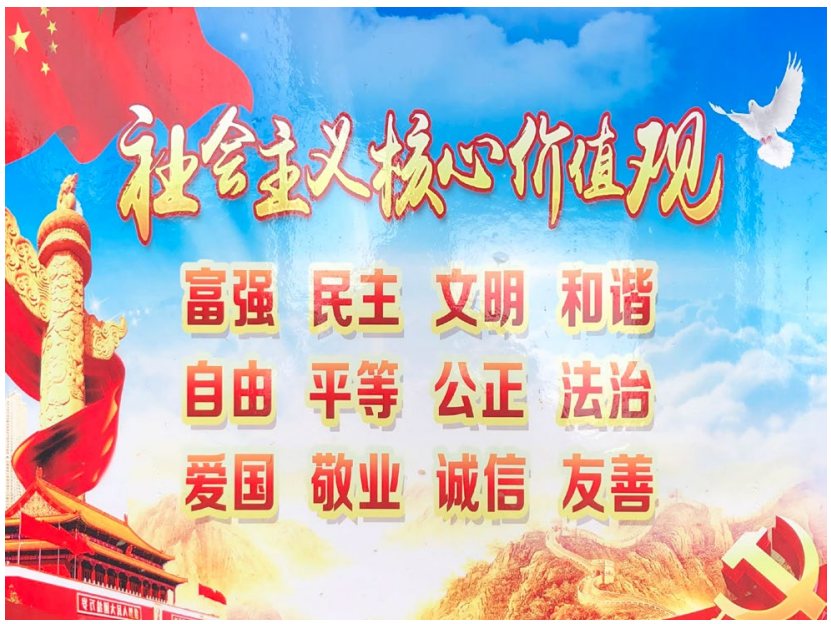

system of rewards and punishments, embracing the logic of self-governance via the 'two handles'. Under some of the trial SCSs, family members and associates of individuals with low social credit scores may also find their own scores lowered, with all that entails.

As with the legalist ideal, these schemes do not apply a single behavioural code to every area of society. Rather, there are sector-specific criteria. There are different sets of rules, rewards, and punishments for the healthcare sector, heavy industry, tourism, business, and education. ${ }^{6}$ This mirrors the ancient system of 'names and tallies'.
Some commentators interpret the promotion of trustworthiness in these schemes as a Confucian measure. ${ }^{7}$ Yet the State Council frames it as a method first to 'further perfect the socialist market economy system' and then to build a 'socialist harmonious society'. ${ }^{8}$ This goal more closely matches the legalist ideal of building a strong and rich state than any Confucian ideal of an empire governed in accordance with the Way (Dao 道).

A spirit of $f a$ and shu underlies the logic of the SCSs. President Xi Jinping makes frequent references to legalist writers in his speeches and books, ${ }^{9}$ as well as to the legalist notions of 'wealth and power' 富强 and the 'rule of/by law' 法治, which 
the Eighteenth Party Congress in the shi necessary to realise what 2012 listed as Core Socialist Values Qin Shi Huang could not: the ideal 社会主义核心价值观. The similarities system of legalist governance. Most with legalist systems of governance people within China are not affected look more than coincidental. While by the SCS, and many do not even the SCS is still in its experimental know of its existence; among those phase, it is difficult to predict its who do, 80 percent approve of it. ${ }^{10}$ At scope or effectiveness. However, this moment, the SCS does not weigh the increasingly sophisticated mass heavily on people's lives. However, if surveillance networks and big data the case of Luo Yonghao is any guide, algorithms currently in development many Chinese citizens who score in tandem with them may provide poorly on the SCS will feel its impact. 


\section{$\mid \begin{aligned} & \text { “EVIL CULTS’ AND } \\ & \text { HOLY WRIT } \\ & \text { Benjamin Penny }\end{aligned}$}

$\mathrm{T}$

WENTY YEARS AGO, a dramatic event brought the Falun Gong to the world's attention. Early on Sunday morning, 25 April 1999, around 10,000 practitioners of the banned religious group gathered to meditate in silence outside the northern and western walls of Zhongnanhai, the compound in which the leaders of the People's Republic of China (PRC) live and work. They were protesting the detention of forty-five of their co-religionists in Tianjin the previous week following another, much smaller, demonstration. After some hours, and much consternation on the part of the officials inside Zhongnanhai, who had no warning that such a demonstration was planned, five designated leaders of the protest were allowed in to meet premier Zhu Rongji 朱F基. Afterwards, all the demonstrators departed peacefully, apparently satisfied. But whatever assurances were given on that day proved empty. Only three months later, on 20 July, the Party-state launched a brutal suppression of Falun Gong. In October, a new law was passed banning Falun Gong and other 'evil cults', as the official translation of xiejiao 邪教 (literally, 'heterodox teachings') has it.

Unsurprisingly, the twentieth anniversary of these events was not observed in Beijing, although groups of Falun Gong practitioners commemorated it in different 
countries around the world.

Gospel of Matthew: 'For as lightning Coincidentally, on 17 July 2019, Zhang Yuhua 张玉华, an adherent of Falun Gong who had been imprisoned in China, became one of twenty-seven 'survivors of religious persecution' from around the world invited to the White House to meet US President Donald Trump. Two days later, a chinese foreign ministry spokesman commented:

Those the US invited to the socalled religious meeting include a member of the Falun Gong cult and some other people who have been smearing China's religious policy ... It [the United States] should stop using religion as a pretext to interfere in other countries' internal affairs. ${ }^{1}$

Although Falun Gong is still illegal in China - and anyone still practising it there does so in secret for fear of certain arrest - the government is now more concerned about another of the religions that features on their list of 'evil cults'. This is the Church of Almighty God 全能神 教会, more popularly known as Eastern Lightning 东方闪电. The latter name derives from a verse in the that comes from the east is visible even in the west, so will be the coming of the Son of Man.' Followers quote this verse to justify their assertion that Jesus has returned to Earth, this time in the form of a Chinese woman. The founders of this millenarian group seem to have been originally affiliated with the Local Church of Watchman Nee, an evangelical group founded in China in the 1930s by Ni Tuosheng 倪柝声, whom the Communists imprisoned for twenty years until his death in 1972. The Church of Almighty God's primary teachings now derive from a new scripture, The Word Appears in the Flesh 或在肉身 显现, which began to be 'revealed' in 1991. For China's more mainstream Protestant churches, both official and unofficial, the beliefs of the Church of Almighty God are heretical. The government focuses on the alleged crimes of church members, including the alleged kidnapping in the early 2000s of members of another church to convert them, and the murder of a woman in a McDonald's restaurant in Zhaoyuan 招远, Shandong province, in 2014. The fact of the murder is not disputed, nor is the fact that the six people who committed it represented 


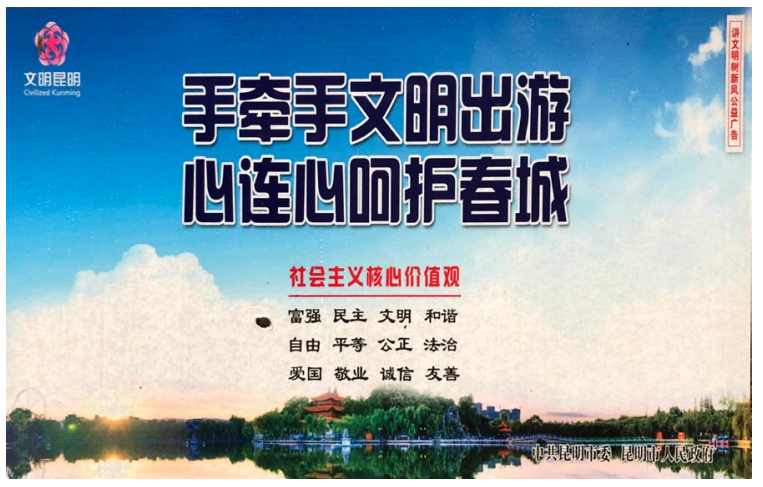

themselves as missionaries of Almighty God. What remains contested is whether the killers ever belonged to the church. Some foreign scholars, such as Massimo Introvigne, agree with the church's position that the six were never members, ${ }^{2}$ while others, such as Australian scholar Emily Dunn, have concluded that the six had once been members but at the time of the murder they belonged to a kind of schismatic microsect who believed they had received their own, new revelations. ${ }^{3}$ Whatever the case, the Church of Almighty God, along with several other new religions that grew out of Protestant Christianity, as well as Falun Gong, remain firmly defined as 'evil cults' according to the Chinese government and continue to be subject to the full force of state suppression.
A more pervasive influence on the realm of religion in 2019 - one less violent and confrontational is President $\mathrm{Xi}$ Jinping's signature injunction to religions to 'Sinicise' 中国化. ${ }^{4}$ Inseparable from his vision of China moving into a New Era, the policy of Sinicisation applies both to religions of foreign origin and to religions that are Chinese or have been present in China for millennia. For Christianity and Islam, this means adopting a 'Chinese style' of architecture, music, and other cultural expressions of faith as well as reworking their liturgies and theology to emphasise what is compatible with Chinese ideas and morality as defined by the Party. For Daoism and Buddhism - for whom an order to Sinicise would appear to be redundant - official pronouncements 
make the direction of the policy as a whole very clear: religions must keep up with the times and be relevant for today's China. How? By 'firmly upholding the Party's leadership' and 'profoundly understanding $\mathrm{Xi}$ Jinping's thinking on socialism with Chinese characteristics', and digging deeply into their traditions to find elements that bolster Xi's Twelve Core Socialist Values (prosperity, democracy, civility, harmony, freedom, equality, justice, rule of law, patriotism, dedication, integrity, and friendship). By so doing, religions can thus 'participate in the national rejuvenation and the fulfillment of the Chinese Dream'. ${ }^{5}$

For many religious believers in China, as well as most scholars of religious studies in Chinese universities and think tanks, these prescriptions are as banal and doctrinaire as they may appear to foreign observers. Yet the weight of official fiat means even officially sanctioned religious groups and their leaders must discuss them, implement them, and report on their fulfillment as if they were great profundities or holy writ. 


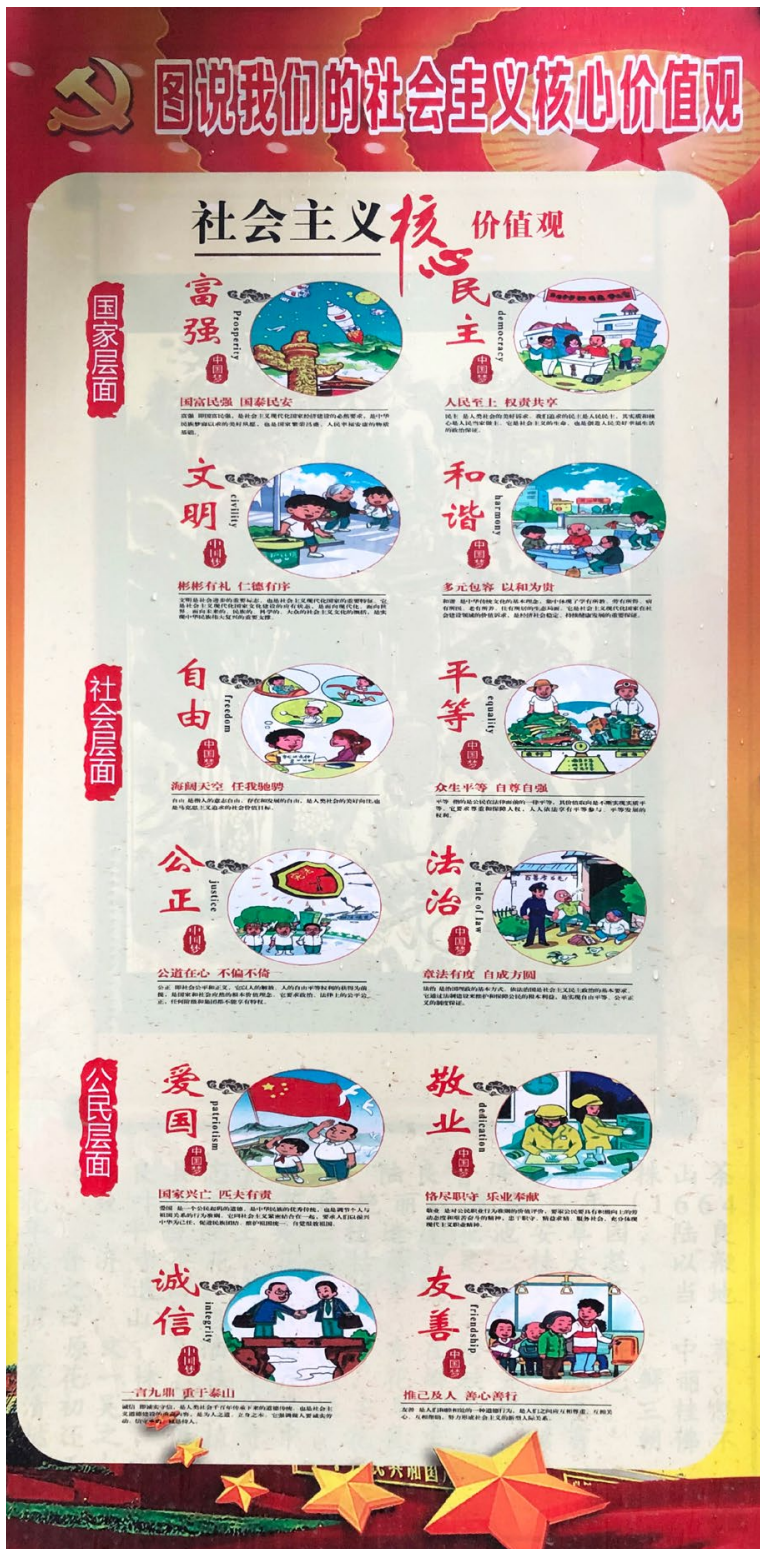

Xi's Twelve Core Socialist

Values: Prosperity,

democracy, civility,

harmony, freedom,

equality, justice, rule of

law, patriotism, dedication,

integrity, and friendship

Source: Benjamin Penny 


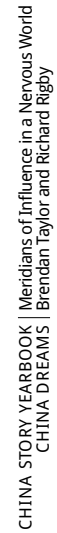




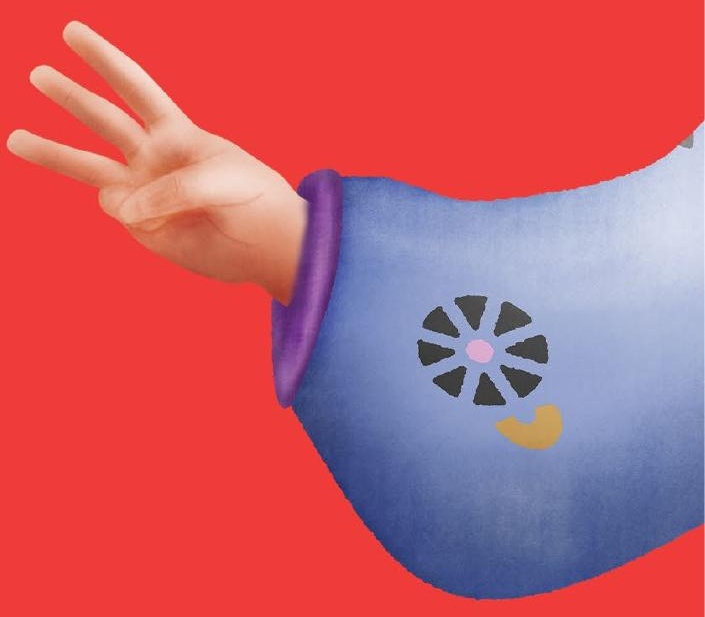




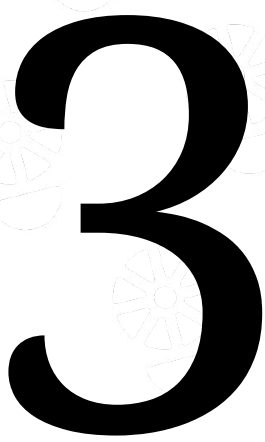




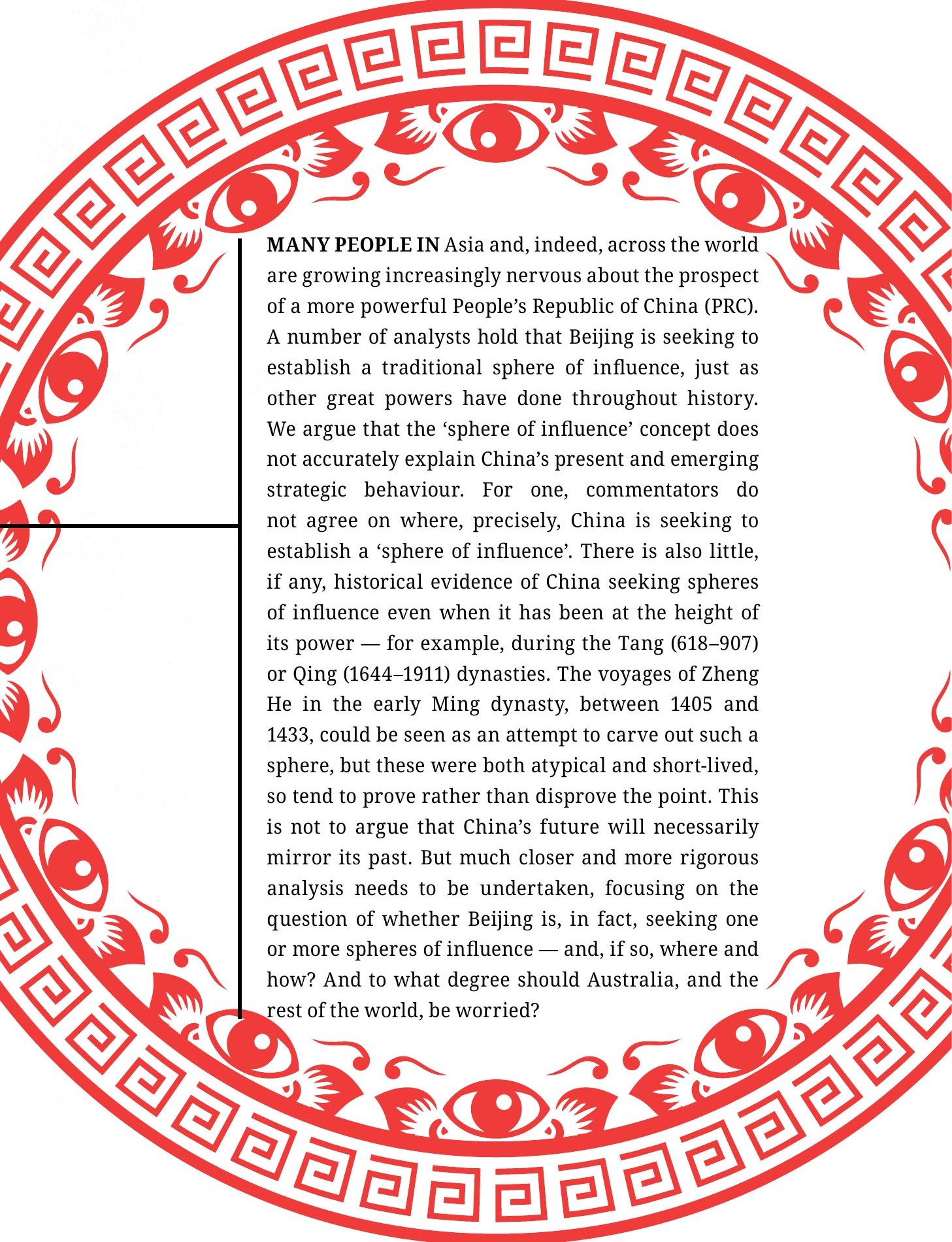




\section{What Are Spheres of Influence?}

The late Australian international relations scholar Hedley Bull dated the practice of states establishing spheres of influence back to the fifteenth century. ${ }^{1}$ The most famous historical example is the so-called Monroe Doctrine of December 1823, wherein US President James Monroe specified that any attempt by a European power to extend its influence into the Western Hemisphere would be regarded 'as dangerous to [America's] peace and safety'. What he

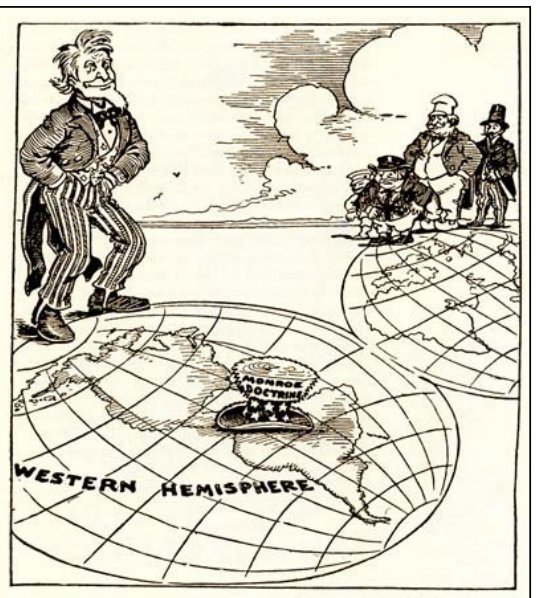

A 1912 newspaper cartoon highlighting the United States' influence in Latin America following the Monroe Doctrine

Source: Wikipedia meant by 'Western Hemisphere' encompassed the Americas (north and south) and their surrounding waters. At the same time, Monroe implicitly recognised European spheres of influence by stating: 'In the wars of the European powers in matters relating to themselves we have never taken any part, nor does it comport with our policy to do so.'2 Interestingly, however, the first recorded use of the term 'sphere of influence' was in 1869, in a letter from Russian foreign minister Alexander Gorchakov to his British counterpart Lord Clarendon, confirming that Afghanistan lay outside the Russian 'sphere of influence'. ${ }^{3}$ The concept rose to prominence during the Cold War period (1947-1991). And yet 'spheres of influence' remain the subject of surprisingly little scholarship. ${ }^{4}$

In one of the few scholarly treatments produced during the Cold War, Bull's protégé Paul Keal defined a sphere of influence as 'a definite region within which a single, external power exerts a predominant influence, which limits the independence or freedom of action of states 
within it'. ${ }^{5}$ Keal noted that a sphere of influence can be understood either formally or tacitly. He also observed that the use of military force within a sphere of influence is rare as the predominant powers generally prefer other instruments of statecraft. Keal thus argued that spheres of influence could potentially be stabilising, because they provide the great powers with guidelines or 'rules of the road' to follow. This was certainly the general pattern during the Cold War. Even during the October 1962 Cuban Missile Crisis, when the Soviets deployed intermediate-range missiles to Cuba - within striking distance of the United States - Moscow ultimately acquiesced to American demands after recognising the upper limits of what Washington was willing to accept within its sphere of influence.

'Spheres of influence' fell from favour after the Cold War. Many people believed that great-power strategic competition would become a thing of the past following the collapse of the Soviet Union, with the rest of the world coming to accept the overwhelming dominance of the sole remaining superpower, the United States, and playing within the rules it set. Over the past decade, however, the term has returned to prominence. After Russia's annexation of the Crimean Peninsula in early 2014, German Chancellor Angela Merkel commented that this was 'a conflict about spheres of influence and territorial claims of the kind we know from the $19^{\text {th }}$ and $20^{\text {th }}$ century [that] we thought we had put behind us'. ${ }^{6}$ The US national security strategy of December 2017 used similar language, charging Russia with attempting 'to restore its great power status and establish spheres of influence near its borders'?

\section{A Chinese Sphere of Influence?}

In one of the only post-Cold War references to the concept before the Russian annexation of the Crimean Peninsula, the American political scientist Robert Ross predicted that twenty-first-century East Asia would be 
divided into distinct Chinese and American spheres of influence. The Chinese sphere would encompass continental East Asia, including North Korea, the Russian border states (such as Kazakhstan, Kyrgyzstan, and Tajikistan), and mainland South-East Asia (namely, Cambodia, Myanmar, Thailand, and Vietnam). The US sphere would extend over maritime East Asia, encompassing Japan, Brunei, Indonesia, Malaysia, and Singapore.

Like Keal, Ross optimistically predicted that this would be a stabilising arrangement. Because these spheres would be separated by water, Ross maintained, military intervention by one power in its own sphere would not threaten the interests of the other power. ${ }^{8}$

There is now considerable divergence of opinion even among analysts who think China is seeking to establish a sphere or spheres of influence as to where precisely its (or their) limits are. Denny Roy, a senior research fellow at the Asia-Pacific Center for Security Studies in Hawai‘i, for instance, argues that China's irredentist claims history-based claims over territory such as the disputed islands in the South China Sea - illuminate the boundaries of its aspirational sphere of influence.

Unlike Ross, Roy views this Chinese sphere as having both continental and maritime dimensions. He sees the disputed land and maritime territories along China's east coast forming

a seamless geographic region beginning with the Yellow Sea in the north and continuing southward through the East China Sea, Taiwan and the Taiwan Strait, and the upper and lower halves of the South China Sea. ${ }^{9}$

The Australian academic Hugh White offers another perspective, seeing the emerging contest for Asian supremacy as one between China and India. White believes the United States will ultimately vacate the region, resulting in this new bipolarity. New Delhi will rapidly realise, according to White, that it has no hope of dominating the Western Pacific and Beijing 
will come to the view that any attempt to establish supremacy in the Indian Ocean would be equally futile. White argues that Asia will thus divide into 'two separate spheres of influence, with China dominating East Asia and the Western Pacific, and India dominating South Asia and the Indian Ocean'. ${ }^{10}$

Other analysts argue that Beijing's forays into the Western Pacific - namely, in the South and East China seas - are largely designed to distract from its primary interest in establishing a sphere of influence in Central Asia. Victoria University's Van Jackson, for instance, contends:

Asia's most extensive sphere of influence involves the rarely discussed border areas surrounding China ... Especially with smaller neighbours who are structurally dependent on Chinese economic ties - including Mongolia, Uzbekistan, Tajikistan, and Kyrgyzstan. ${ }^{11}$

Nadège Rolland of the American National Bureau of Asian Research concurs. She regards burgeoning Sino-Russian collaboration as temporary, maintaining that it will eventually give way to Chinese dominance. In Rolland's words:

Russia is presumed to be bitter and resentful of China's rising economic, political and military capabilities, and its increased presence in areas that Moscow still covets as its exclusive sphere of influence.

In the long run, she argues: 'Russia will become a toothless former superpower, surrendering the stage for Beijing to fully assert its own influence over Eurasia. ${ }^{12}$

Yet another interpretation sees China seeking a sphere of influence further afield, in South-East Asia or even the South Pacific. Paul Dibb of The Australian National University's Strategic and Defence Studies Centre contends that 'Southeast Asia is likely to be a focus of Chinese power and coercion and become a zone for incremental steps towards 


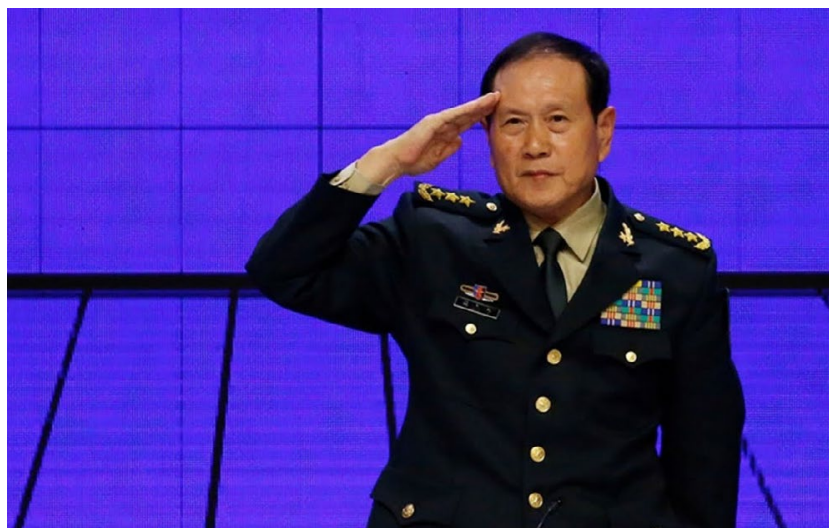

Chinese hegemony and a sphere of influence'. ${ }^{13}$ Some commentators have also alluded to the possibility of growing Chinese power encroaching on Australia's sphere of influence in the South Pacific - typically defined as the areas to the north and north-east of Australia, from Papua New Guinea and Solomon Islands to Vanuatu and Fiji. Writing in July 2019, White posed the question: 'What can Australia do, then, to restore and preserve our sphere of influence in the South Pacific, and deny it to China?'14

China rejects any suggestion it is seeking spheres of influence in the South Pacific or elsewhere. In May 2019, the Chinese Foreign Ministry issued a statement paraphrasing a speech given by President Xi Jinping during a visit to Beijing by Vanuatu's Prime Minister: 'We have no private interests in island countries, and do not seek a so-called "sphere of influence". ${ }^{15}$ The following month, addressing the Shangri-La Dialogue, Chinese Defence Minister Wei Fenghe 魏凤和 asserted that 'in the future, no matter how strong it becomes, China shall never threaten anyone or establish spheres of influence'. ${ }^{16}$

What is to be made of these competing interpretations of China's actions and intentions? It could be that the application of this concept to the Chinese case is simply inappropriate. 


\section{Getting China Wrong?}

The American scholar David C. Kang, author of the article 'Getting Asia Wrong: The Need for New Analytical Frameworks', published in International Security, cautions against applying concepts of predominantly European origin to an Asian setting. He has long been sceptical that Asia - with its unique and highly diverse histories, cultures, economies, and demographics - can be considered an entity similar to Europe, for example. He believes that new and different analytical frameworks are needed for Asia. In his words:

This is not to criticize European-derived theories purely because they are based on the Western experience: The origins of a theory are not necessarily relevant to its applicability. Rather these theories do a poor job as they are applied to Asia. ${ }^{17}$

There are certainly some historical precedents from the Chinese experience that suggest that the term 'sphere of influence' may not be entirely inappropriate. Some might argue, for instance, that the traditional Chinese vision of world order known as 'Tianxia' 天下 or 'All-UnderHeaven' is analogous to a sphere of influence. Tianxia dates back to the Zhou 周 period (1046-221 BCE) and is a conceptual model for a world order based on the family. It is inclusive of all peoples, living in harmony with an absence of hegemony; it represents, in that respect, the very antithesis of the idea of predominance that lies at the heart of the spheres of influence concept. ${ }^{18}$ But it is really more of a worldview than a practice of statecraft.

The Chinese tributary system arguably makes for a better analogy. The tribute system, which guided early modern East Asian international relations, was hierarchical in nature. Neighbouring states were required to recognise Imperial China's dominance. In return, China showed restraint towards its neighbours and would even provide them material benefits - among them, mutually beneficial trade. Yet the tribute system 
required acknowledgement of China's cultural superiority. Rank in the hierarchy was determined by a state's cultural similarity to China. There was little, if any, attempt to achieve political dominance over these states, however, which were largely given a free hand to run their own domestic and foreign policies as long as they did not go directly against China's interests. ${ }^{19}$ This, once again, stands in contrast to the lack of independence and freedom of action experienced

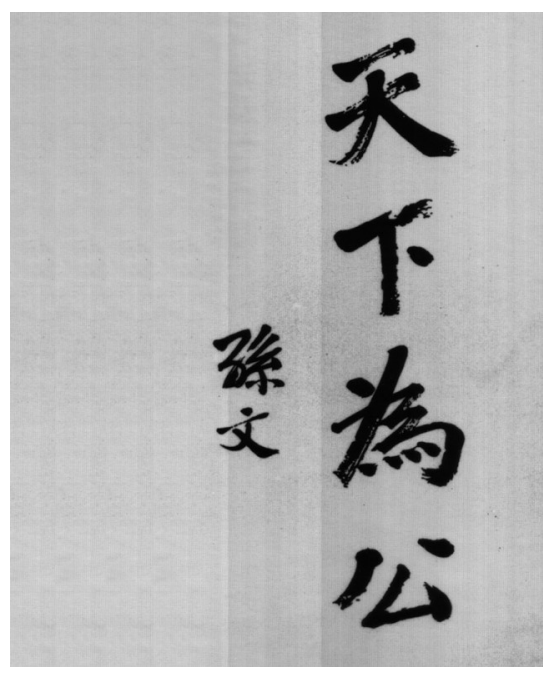

'The World is For All': Calligraphy by Sun Yat-sen, 1924 Source: Wikimedia Commons by subservient states within a traditional sphere of influence.

China's historical experience with foreign spheres of influence was extremely negative. In China, the concept is most commonly associated with the 'century of humiliation', which started with the Opium Wars (1839-1860) and culminated in the Sino-Japanese War (the Japanese invasion and occupation) of 1937-1945. During this period, China was essentially carved up by Europe's major powers and East Asia's rising one into spheres of influence in the context of their larger contest for supremacy. Central to his signature China Dream is President Xi's pledge to make the country so wealthy and powerful that it will never again be subject to such treatment. According to official Chinese pronouncements such as those quoted above, however, this will not include creating 'spheres of influence' as such.

It could be more useful to look at the term that the Party-state under Xi favours when it talks about coalition building: the 'community of shared destiny’ (see the China Story Yearbook 2014: Shared Destiny, Chapter 2 
'Whose Shared Destiny?, pp.59-73) — or, as it is now generally referred to, a 'community of shared future for mankind'. Foreign Minister Wang Yi explains:

As China enters the critical stage of the great national renewal, its future and destiny are ever more closely connected with that of the world. As part of advocating and advancing the building of a community of shared future for mankind, China will promote the interests of its own people in conjunction with the common interests of people all over the world and pursue the Chinese dream in the course of attaining the dream of the whole world, thus adding a more profound global significance to the great renewal of the Chinese nation.

The slogan embodies a vision of China as a 'responsible major country', synergising its 'development with the common development of the world'. According to Wang, in promoting

a shared future for mankind, China encourages all countries to coexist peacefully, engage in sound interaction and seek win-win cooperation. This in turn will create a favorable environment for the great renewal of the Chinese nation. ${ }^{20}$

\section{Moving the Needle}

Whatever the true ambitions of the Party-state under Xi, China's ability to establish a sphere of influence - by whatever name - across the entire Asian region is limited and will likely remain so. The presence of other major powers in this part of the world - the United States, India, and Japan - will prevent this from happening. It is true that China may ultimately become stronger than any of these countries. But it remains hard to imagine a situation where it develops the ability to significantly limit their independence or freedom of regional manoeuvring. 
Beyond the major powers, recent polling conducted by the Pew Research Center shows that unfavourable views of China have increased across the Asia-Pacific, with resistance to even seemingly anodyne goals such as the 'community of shared destiny' making them harder for Beijing to achieve. ${ }^{21}$ Consistent with these findings, the Lowy Institute's 2019 poll of Australian attitudes towards the world found that only 32 percent of respondents said they trusted China. This was a 20 percent drop from the previous year and the lowest result since the poll commenced in 2005. ${ }^{22}$ Beijing may have better luck in Central Asia, but that will depend on whether Moscow is willing to tolerate (or able to prevent) Chinese encroachment into what it regards as its own traditional sphere of influence.

In the longer term, a Chinese sphere of influence in the South China Sea is also conceivable. To be sure, much has been made of China's building and militarisation of artificial islands here. But the South China Sea covers some 3.7 million square kilometres. Notwithstanding the impressive gains China's military has made since its second modernisation drive in the 1990s (the first being the one prompted by Deng Xiaoping as part of the Four Modernisations in 1977), it is an exercise that reflects Chinese weakness as much as strength. The primary rationale for these islands was to compensate for China's shortcomings relative to the United States when it came to aircraft carriers - the sine qua non of military power projection - even if some commentators now question the continued utility of these platforms in a world of more powerful and accurate antishipping missiles. ${ }^{23}$

Most improbable of all is the prospect of China developing a sphere of influence in the South Pacific, although it may establish a military base here. Rumours circulated in April 2018 that Beijing was in discussions with Vanuatu regarding this very prospect - speculation that was swiftly quashed by Port Vila. ${ }^{24}$ But the South Pacific is a long way from China and, in particular, from the focus of the Belt and Road Initiative. Power projection would be even more challenging for Beijing here than in the 


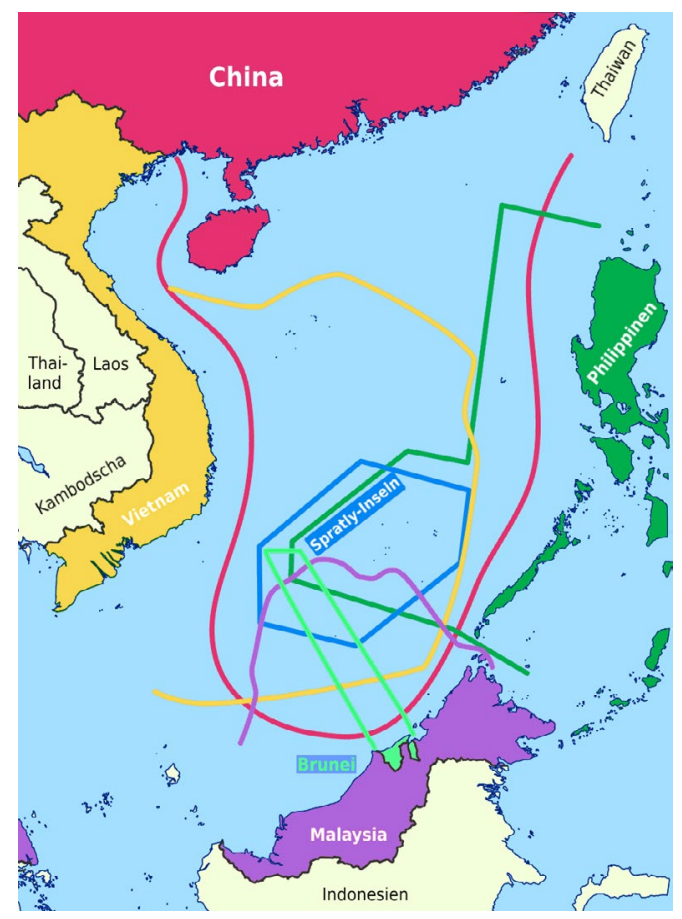

Territorial claims of the various South China Sea claimants

Source: Wikimedia Commons

South China Sea, especially during periods of conflict. The South Pacific's strategic importance to Beijing is less than that of the South China Sea and the Indian Ocean, where access to sea lanes is critical. Rather, Beijing's interests in the South Pacific relate to this region's resource potential - including in fisheries, timber, minerals, gold, nickel, and liquified natural gas - and, with an estimated 20,000 Chinese nationals living in the region, the ability to evacuate them should there be a crisis. ${ }^{25}$

This is good news for Australia. On grounds of likelihood and proximity, the spectre of a South-East Asian sphere of influence is one that Australian policymakers will be watching more closely. But even this is far from a foregone conclusion given the tensions in the South China Sea, which continued to simmer along in 2019, with Vietnam 


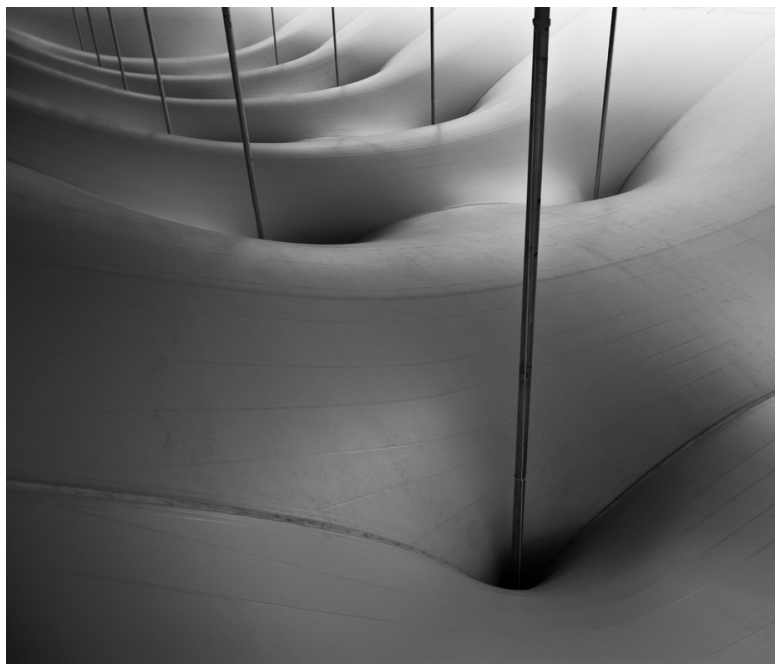

Does 'acupuncture diplomacy' better account for China's present and emerging strategic behaviour?

Source: Pscheirer, Flickr

even banning the American-Chinese co-produced children's animation Abominable over a scene displaying China's contentious Nine-Dash Line map claiming sovereignty over mutually disputed islands. ${ }^{26}$

\section{Acupuncture Diplomacy}

Rather than seeking any kind of traditional sphere of influence in the historical European sense of the term, it is worth considering whether Beijing might, instead, be engaging in the longstanding Chinese practice of what we suggest calling 'acupuncture diplomacy'. The traditional Chinese medicinal technique involves probing specific 'acupuncture points' with a fine needle to gauge the reaction and make fine adjustments to the flow of $q i$, the vital essence or energy that flows across the body's meridians, or pathways, freeing blockages, calming it where appropriate, and strengthening it where that is judged to be what is needed. In the case of acupuncture diplomacy, offers of loans, infrastructure building, aid, 
invitations, or scholarships might be just what are needed to get blocked relations flowing again. Solomon Islands politicians, for example, were allegedly offered hundreds of thousands of dollars to cut ties with Taiwan and to formally re-establish relations with the mainland in September $2019 .{ }^{27}$ In the final analysis, this idea of 'acupuncture diplomacy' may better account for China's present and emerging strategic behaviour. 
论坛 

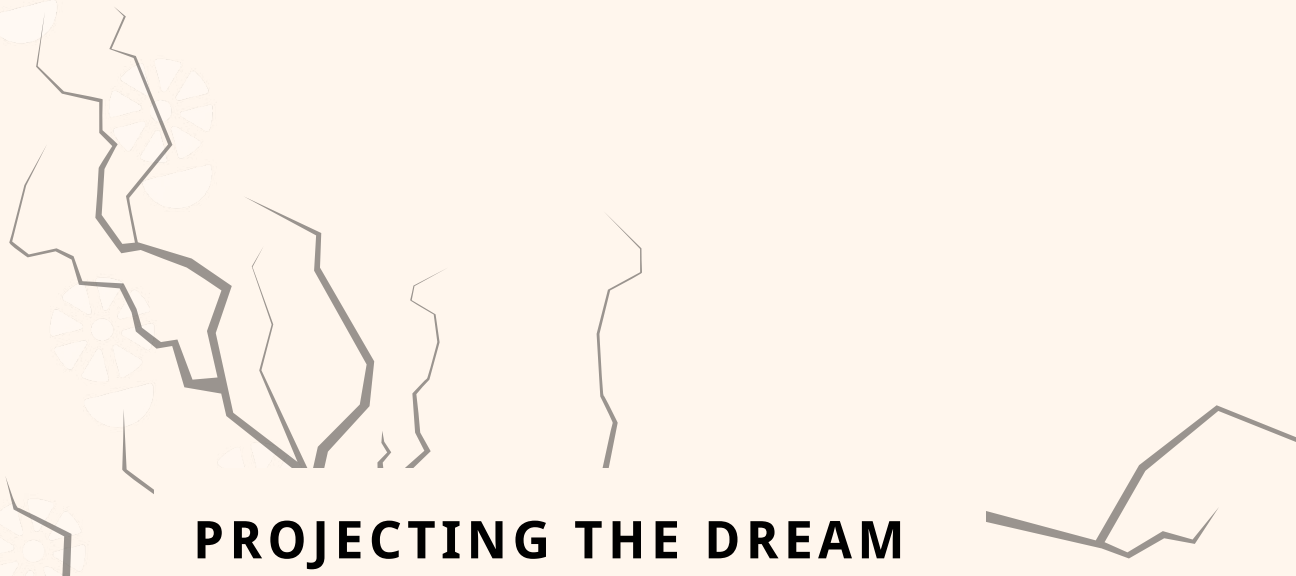

Dreams in Space

- ADAM NI

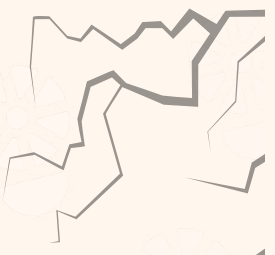

Antarctic Ambitions: Cold Power

- BEYONGO MUKETE DYNAMIC
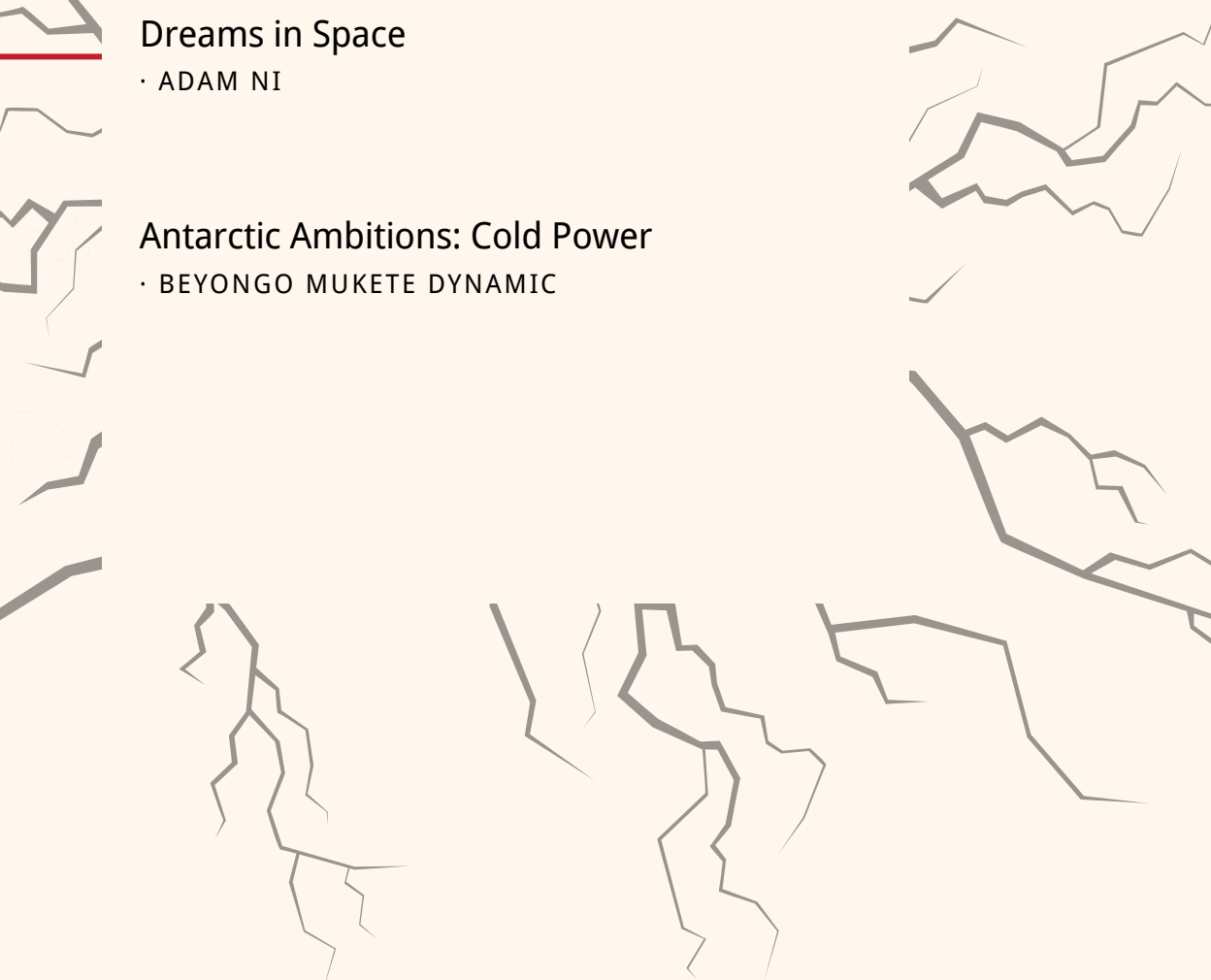


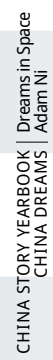




\section{DREAMS IN SPACE Adam Ni}

$\mathrm{O}$

N 3 JANUARY 2019, the People's Republic of China (PRC) made history by becoming the first country to land a spacecraft on the far side of the Moon. ${ }^{1}$ The China National Space Administration hailed the successful landing of the Chang'e 4 probe as the opening of 'a new chapter in humanity's exploration of the Moon'. Indeed, beyond this momentous achievement, China's great leap forward in space technology and activities in recent years is closing the gap between China and the established space powers.

Driven by national pride and the pursuit of international prestige, as well as technological and economic imperatives, terrestrial strategic interests, and national security considerations, China is investing billions in its space program. It spent about US $\$ 8.4$ billion in 2017 alone - almost three times as much as Russia, although still less than the United States, which spent US\$14 billion. According to the 2016 white paper on space activities released by the State Council Information Office, China's space program aims 'to provide strong support for the realisation of the Chinese Dream of the renewal of the Chinese nation'. ${ }^{2}$ In the words of President Xi Jinping, 'the space dream is part of the dream to make China stronger' ${ }^{3}$

China's space dream is highly ambitious, with orbital, lunar, and deep-space activities planned for the next two decades. Closer to Earth, China is sending up satellites at a rapid rate to build satellite constellations for navigation and global positioning, communications, observation, remote 


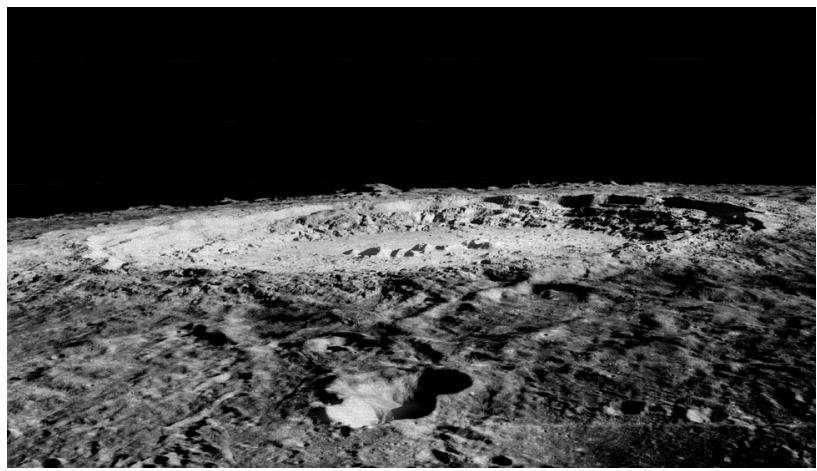

sensing, and imagery. ${ }^{4}$ In 2019, China conducted around 30 orbital launches - more than any other country. ${ }^{5}$ At the level of near-Earth orbit, just as the International Space Station which is funded mainly by the United States, Russia, and the European Union - is facing funding uncertainties that could see it decommissioned by 2025, China is looking to launch its own space station, with construction scheduled to finish in 2022. ${ }^{6}$ It will welcome international astronauts and spacecraft, too, so long as the latter are equipped with a Chinese docking mechanism. Looking to the Moon, China plans to send four more probes to explore the lunar surface before embarking on a crewed lunar landing mission and possibly the construction of a lunar outpost in the 2030s. ${ }^{7}$ Plans are also under way for deep space exploration missions to Mars, Jupiter, and asteroids from the early 2020s. ${ }^{8}$

China's lofty space dream is backed by political endorsement from the top, sustained and substantial financial investment by the state, and policies that aim to foster a vibrant space industry. Since China's opening of the space sector to private companies in 2014, the number of Chinese space start-ups has ballooned to more than one hundred. ${ }^{9}$ In July 2019, a fourstage small commercial carrier rocket developed by the Beijing-based rocket developer ispace achieved the first successful orbital launch by a private Chinese firm. ${ }^{10}$ If China is to become a top space power, private innovation will likely play an increasingly important role in complementing state-backed programs. 
Until now, China's space ambitions have been carefully couched in a narrative that centres on expressions such as the 'exploration and utilisation of outer space for peaceful purposes' and 'multilateral cooperation'. ${ }^{11}$ This is not surprising. China's rapid advances in space worry some in the international community, including the administrator of the US National Aeronautics and Space Administration (NASA), Jim Bridenstine, who in September 2019 described China's activities in space as 'aggressive'. ${ }^{12}$ Regardless of whether one agrees with such characterisation, what is certain is that Beijing's pursuit of space power is intimately connected to its growing terrestrial footprint and interests - in other words, to geopolitics.

Beijing will certainly gain political influence through some China-led space initiatives, such as the Belt and Road Initiative Space Information Corridor, the launch of a remote-sensing satellite constellation for the BRICS countries (Brazil, Russia, India, China, and South Africa) and the Asia-Pacific Space Cooperation Organization Joint Small Multi-Mission Satellite Constellation Program. ${ }^{13}$ It is also cooperating bilaterally with countries including France and Italy on satellites to monitor such things as climate change and earthquake activity. These initiatives will tie participating countries tighter into China's own orbit, both on Earth and beyond.

Beijing is keenly aware of the importance of space to national security. According to China's 2019 defence white paper, 'space is a critical domain in international strategic competition [that] provides strategic assurance for national and social development'. ${ }^{14}$ China's military has prioritised the development of space capabilities to support its expanding military footprint on Earth as well as to counter potential adversaries in space. At the end of 2015, the People's Liberation Army (PLA) established the Strategic Support Force (SSF) 战 略支援部队. It consolidates military space and cyber warfare capabilities across the PLA to facilitate integrated operations. ${ }^{15}$ Its creation highlights the importance of the new 'strategic frontiers' 战略边疆 of space and cyberspace for China's hard power as well as its broader strategic interests, including economic growth and technological development. ${ }^{16}$

Beijing is also eyeing off commercial opportunities in space, 
including the exploitation of resources. The Moon, for example, hosts large quantities of rare-earth elements and helium-3 - a rare element that can be used in nuclear fusion. ${ }^{17}$ China reportedly aims to establish a 'space economic zone' in 'cislunar space' (inside the Moon's orbit) by mid-century, with a staggering estimated yearly economic output of US $\$ 10$ trillion. ${ }^{18}$

Beijing's space ambitions may have a sovereign aspect to them as well. In the words of Ye Peijian 叶培建, the head of China's lunar exploration program:
[T]he universe is an ocean, the Moon is the Diaoyu Islands and Mars is Scarborough Shoal. If we don't go there now when we can, our children would blame us. If others go there and take over, then [we] wouldn't be able to go. That is reason enough. ${ }^{19}$

The Diaoyu/Senkaku Islands are claimed by both China and Japan, while the Scarborough Shoal is claimed by China, Taiwan, and the Philippines. China's approach to these and other territorial disputes on Earth

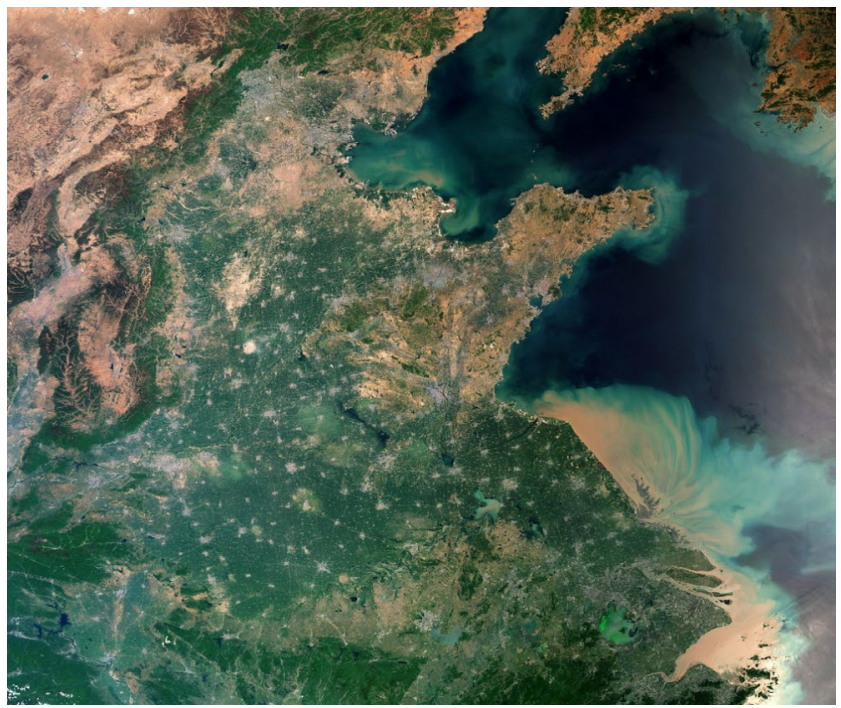

China is sending up satellites into space at a rapid rate

Source: European Space Agency 
raises questions about how it will conduct itself in space with respect to the global commons. This is uncharted territory.

China's rapid rise as a major space power and its grand ambitions in space are intimately tied to terrestrial geopolitics. A key question is whether China will ultimately tilt towards collaboration or competition in space. Some observers think a confrontational space race is already under way between China and the United States. ${ }^{20}$ Following China's lunar success, the United States announced that it would speed up its own plan to return to the Moon, by 2024. In a speech in March 2019, US VicePresident Mike Pence said: 'Make no mistake about it: we're in a space race today, just as we were in the 1960s [with the Soviet Union], and the stakes are even higher.' He called on NASA to meet the challenge with 'new urgency' and focus. ${ }^{21}$ In the words of Bridenstine: 'Some people call space - China specifically - the American Achilles' heel. ${ }^{22}$

As the country once known as the Celestial Empire reaches for the stars, lines from a 1965 poem by Mao Zedong come to mind:

We can clasp the moon in the Ninth Heaven

And seize turtles deep down in the Five Seas:

We'll return amid triumphant song and laughter. Nothing is hard in this world If you dare to scale the heights. ${ }^{23}$ 


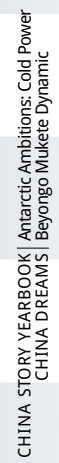




\section{ANTARCTIC AMBITIONS:
COLD POWER
Beyongo Mukete Dynamic}

$\Lambda_{\text {metres above sea level and }}^{\text {NTARTICA'S DOME A, 4,000 }}$ near the centre of East Antarctica, is one of the best places on Earth from which to observe space. The Antarctic convention is that, when more than one country has a scientific interest in an area of the continent, such as Dome A, that country may suggest a 'code of conduct'; if accepted, that country manages the area's use. At the annual summit of nations with a presence in Antarctica, held in late July 2019 in the Czech Republic, the People's Republic of China (PRC) proposed a code of conduct for Dome A. The Australian government, which claims sovereignty over forty-two percent of the Earth's southernmost continent, firmly rejected the proposal. ${ }^{1}$

Scientists maintain that Antarctica holds large reserves of natural resources. It is also strategically located for military and space operations. Although the landmass is covered in ice, several countries including Australia and China maintain both seasonal and permanent stations in the region. ${ }^{2}$ Australia's sovereignty claim is historical. Between 1911 and 1914, a group of Australians led by Sir Douglas Mawson undertook the country's first expedition to the Antarctic aboard the wooden ship, SY Aurora. ${ }^{3}$ However, Australia's territorial claims in the 
Antarctic date back to 1841, when the British government claimed 'Enderby Land' in the north-east of the continent. The British government formally transferred the territory to Australia in $1933 .^{4}$

Beijing's proposed code of conduct is part of several Chinese activities in Antarctica that have raised questions about its intentions. ${ }^{5}$ In 2016, with China's presence in the region on the rise and growing concern that Beijing intends to challenge legal and operational norms there, the Australian government proposed a policy to protect and maintain the status quo. ${ }^{6}$

China's interest in the Antarctic is not new, however. In 1977, the Chinese government requested permission for Chinese scientists to take part in an Australian Antarctic expedition; two participated in Australia's 1979-1980 annual austral-summer Antarctic expedition. ${ }^{7}$ In 1981, Australia invited five Chinese scientists 'in the hope that, through this assistance, [Australia] could influence China's future policies on Antarctica in Australia's favour'. The Chinese government, working cooperatively with the Australian government, built its second Antarctic base in 1989 on Australian Antarctic
Territory. By 2019, China had five bases there, including the Kunlun base, built in 2009, on Dome A.

Since establishing its first base in 1985, China has become a leading polar player and the nation with the biggest national investment on the continent. ${ }^{9}$ Beijing's large-scale investment in the region has raised concerns that, in the long term, Beijing will challenge existing territorial claims, develop bases in strategic locations, block freedom of operations in the region, and engage in resource exploitation contrary to the existing Antarctic Treaty System (ATS). ${ }^{10}$

The ATS is the continent's system of governance. Member nations of (or parties to) the ATS meet annually to discuss pressing issues. Only consultative parties that have demonstrated their interest in Antarctica by 'conducting substantial research activity there' may take part in decision-making processes. ${ }^{11}$ The ATS consists of the Antarctic Treaty, which was enacted in 1959 and came into force two years later, and the Madrid Protocol, which was enacted in 1991 and came into force in 1998; Australia is an original signatory to both. China ratified the Antarctic Treaty in 1983 and gained consultative status with voting 


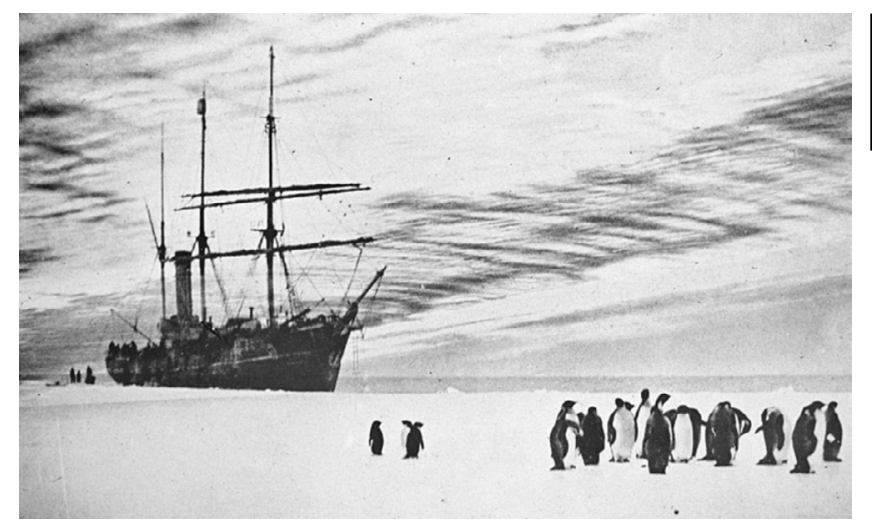

rights in 1985. It is also a signatory to the Madrid Protocol. ${ }^{12}$

Scholars have warned that the ATS is too weak to regulate the ambitions of Beijing (and Russia) or to guarantee the long-term interests of Australia and other claimant states. ANU Antarctic expert Elizabeth Buchanan, writing in The Strategist in September 2019, argues:

The Antarctic Treaty System worked well in the 1960s, when nuclear weapons were seen as the key to global security. But this Cold War peace agreement is inadequate to respond to the security challenges of the 2020s. ${ }^{13}$

She and other observers suggest that the strategic importance of the Antarctic region to China's military and global political ambitions will likely outweigh Beijing's deference to the ATS. ${ }^{14}$ Arguing that the ATS is less a 'long-term fix' and more of 'a stop-gap solution to the issue of who owns the continent', Buchanan notes that Cold War fears of a 'red continent' have materialised, with China 'the emerging heavyweight there' (and notably, an active Russian presence as well).

Another point of concern over the viability of the ATS, through which territorial claims in the Antarctic are managed, is whether China may start to challenge existing claims or make its own. There are currently seven claimants to the continent: Australia, Argentina, Chile, France, Norway, New Zealand, and the United Kingdom. Marie Byrd Land in West Antarctica is unclaimed, while only New Zealand, the 


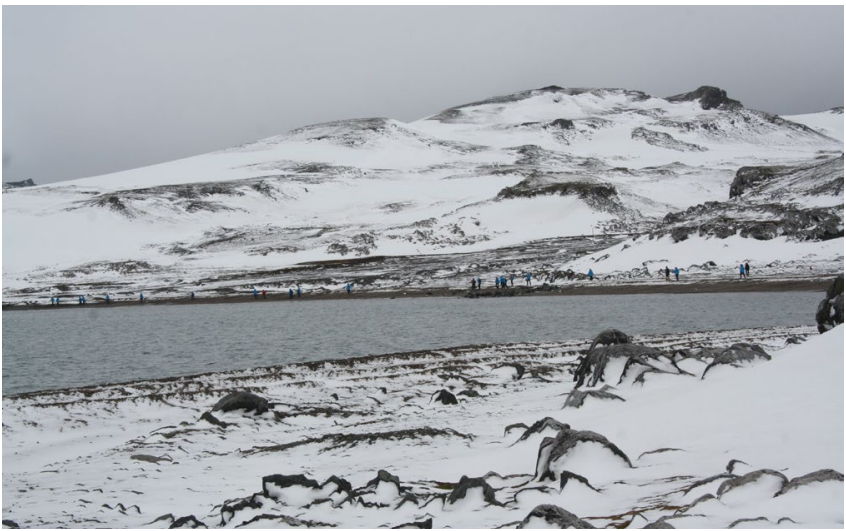

United Kingdom, France, and Norway recognise Australian sovereignty in Antarctica.

New Zealand scholar Anne-Marie Brady, author of China as a Polar Great Power, has pointed out that, while the ATS currently prevents new claims, from 2049, the treaty system will be open for modification or amendment, which may pave the way for Beijing to challenge the status quo. ${ }^{15}$

In contrast, legal scholar Nengye Liu of Adelaide University argues there are enough safeguards within the ATS to prevent China from undermining the current system: 'The Chinese Government is in persistent support of the purposes and gist of the Antarctic Treaty, and has been committed to safeguarding the stability of the ATS. ${ }^{16}$ Liu notes that although the Antarctic Treaty may be modified or amended at any time, unanimous agreement of the contracting parties must be achieved to do so. It is a mission impossible for China to persuade all other consultative parties so as to amend the Article IV to facilitate any potential claim. ${ }^{17}$

Liu warns of the dangers of exaggerating the threat posed by China to Australia's interests. Yet the Australian government has begun to take a tougher approach to China's presence in the region, announcing the Australian Antarctic Strategy and 20 Year Action Plan at the end of 2018, which will assert Australia's interests in the region and work to protect the ATS. ${ }^{18}$ 
The strategy encompasses the if relations between Beijing and maintenance of freedom of navigation Canberra continue to deteriorate. It in the Antarctic, the preservation may not be Cold War II just yet, but of Australian sovereignty over its 'cold power' games in Antarctica are territorial claims, support for 'a strong and effective Antarctic Treaty system', and increased funding for 'world-class scientific research consistent with its national priorities'. ${ }^{19}$

China's growing presence in the Antarctic is likely to continue to raise concerns about its intentions and its effects on the existing legal framework and territorial claims, particularly well and truly under way.

However, within thishypersensitive milieu, Beijing's capacity to undermine the ATS may be overestimated. While it may be too early to understand Beijing's true intentions in the Antarctic, Australia and other countries seem poised to keep an eye on China's operations in the region. 


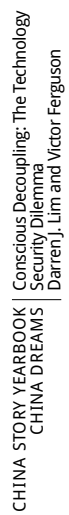




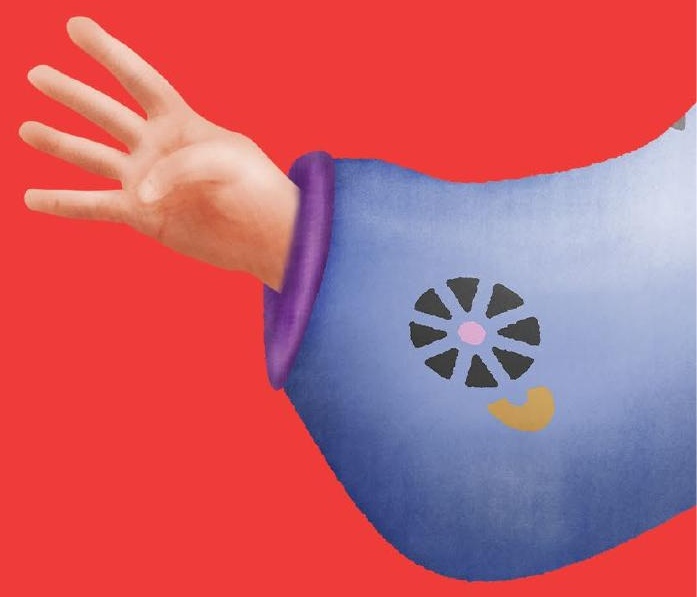




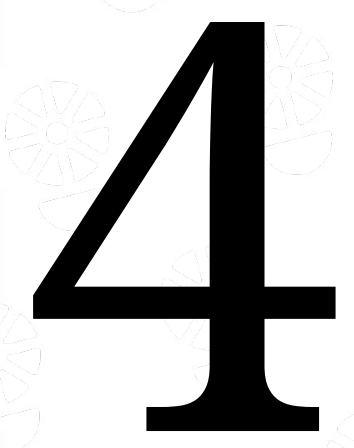




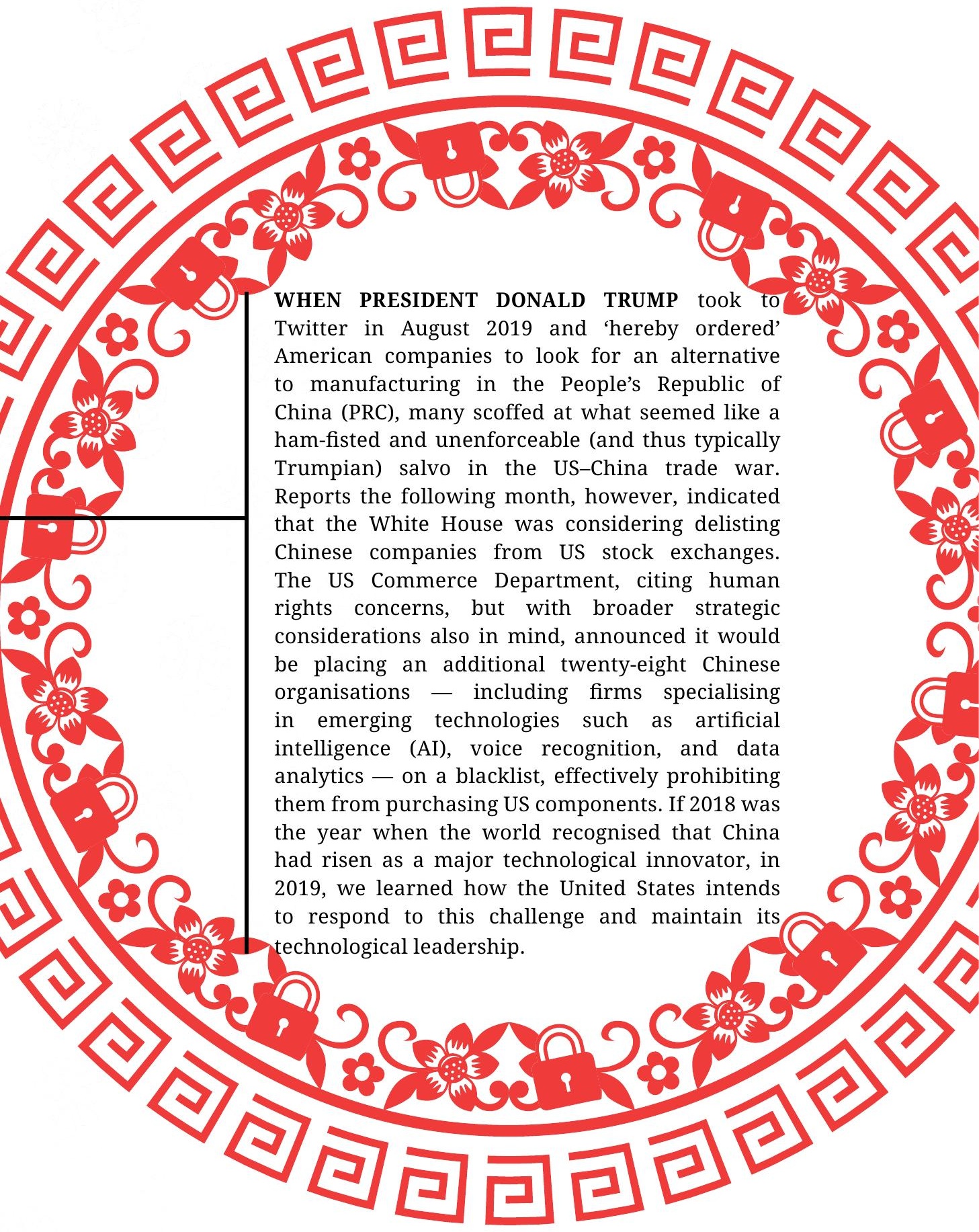


This was the year the concept of 'decoupling' graduated from being an academic talking point to a real-world dimension of the bilateral relationship. ${ }^{1}$ Decoupling refers to the process by which the deep economic interdependence binding the United States and China over the past four decades would be unwound, especially (but not exclusively) in high-tech industries. While senior figures in Beijing downplay this prospect as unrealistic, ${ }^{2}$ a growing number of Chinese academics warn that it is 'completely possible'3 and some national security experts in the United States declare it 'inevitable'. ${ }^{4}$ Many global business leaders appear to share the last expectation. ${ }^{5}$ In the short to medium term, technological decoupling would impose real costs on both economies, not to mention the collateral damage to the existing supply chains of their trading partners across the world. In the longer term and taken to the extreme, decoupling could result in a bifurcation of the global economy, with other states facing a binary choice between US-centred and Chinese-centred alternatives for a growing number of high-tech ecosystems, for the end-use products themselves, as well as the education, research and development (R\&D) processes, and supply chains that lie behind them.

At its essence, the decoupling concept falls into the category of policy decisions that involve sacrificing the economic benefits of openness

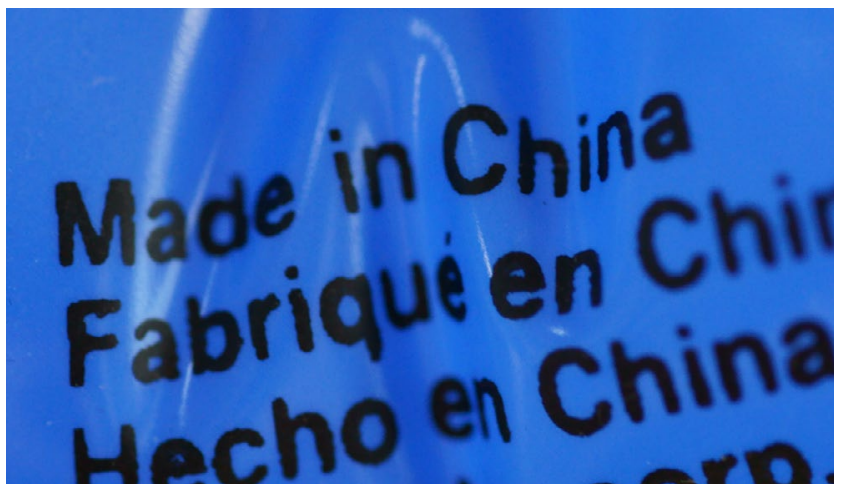


- flows of goods, capital, people and/or ideas, and information - in the name of other national interests. Invoking a concept developed by security studies scholarship during the Cold War, we argue that China and the United States are caught in a 'technology security dilemma', in which mutual insecurity is driving efforts to decouple on both sides, and that such a trend, despite the economic sacrifices it entails, is likely to persist over the longer term.

\section{Sources of Insecurity}

For the United States, decoupling is a consequence of what Washington labels China's 'economic aggression'. The Trump White House cites a broad range of acts undertaken by Chinese commercial actors as well as official economic policies that it claims pose a fundamental threat to US national security and broader economic interests. These include intellectual property theft via industrial espionage or forced technology transfer, extensive state subsidies and other forms of assistance to support 'national champions' in the technology space under Beijing's Made in China 2025 (MIC 2025) initiative, and discriminatory licensing restrictions imposed on foreign firms operating in China. Cumulatively, the argument goes, these actions provide Chinese technology companies with an unfair advantage, while also harming the national security of the United States.

In its 2017 national security statement, the White House claimed that 'economic security is national security' ${ }^{6}$ Linking economic activity with national security is not new; during the Cold War, for example, the United States used export controls to limit the military capabilities of the Soviet Union. ${ }^{7}$ What is new is the extensive scope of technology related economic activities deemed to affect national security. It is undeniable that many new technologies designed for consumers can have military applications. The interconnected and technology-driven nature of modern life also leaves a country such as the United States 
vulnerable to the hacking of critical infrastructure, cyber espionage, and political interference, through the manipulation of social media, for example. The link between economics and security is further strengthened by the belief that the national security of a leading power will be eroded if it falls behind in technological innovation vis-á-vis a strategic rival, or otherwise loses competitiveness or market share in high-tech industries. ${ }^{8}$

Washington has responded with a broad range of measures to limit or otherwise manage exchange between the two economies. It has introduced tariffs targeting a broad range of Chinese products including industrial technology targeted in MIC 2025. It has tightened restrictions on inward investment and broadened the scope of the Committee on Foreign Investment in the United States (CFIUS) to review and block Chinese investment targeting 'critical technology' and introduced new controls on the export of 'emerging and foundational technologies'. More controversially, Washington has targeted Huawei, ZTE, and other Chinese technology companies, ostensibly for sanction violations and human rights concerns, and indicted a range of Chinese nationals and firms on allegations of industrial espionage. ${ }^{9}$ With the possible exception of some tariffs, these measures do not appear to be anomalous manifestations of Trumpism. There is broad bipartisan consensus in Washington for action to address the perceived Chinese threat to US technology leadership. ${ }^{10}$

Beijing, on the other hand, argues that such national security concerns are overblown, misguided, or made in bad faith. The Chinese government believes that Washington's policy responses are not defensive but part of a broader containment strategy designed to slow or stop China's economic development and rightful rise as a science and technology leader. Many in Chinese academic circles share these views. ${ }^{11}$ By seeking to limit China's technological advancement, Washington has exacerbated Beijing's perceptions of insecurity. 


\section{The Internet: Where Decoupling is Already a Reality}

Former Australian prime minister Kevin Rudd has pointed out that decoupling has already occurred online between the two major powers as a consequence of the differences in their political systems. ${ }^{12}$ China's construction of the 'Great Firewall' and restrictions on content effectively block the inward flow of politically 'sensitive' information and ideas from the outside world. The Chinese Communist Party (CCP) views a free and open Internet as incompatible with its Leninist Party-state model of authoritarian governance, and potentially a direct threat to its own legitimacy. For China, controlling the Internet is fundamental to national security and public order. This outweighs any potential economic benefits that might be reaped from allowing the likes of Facebook, Google, or The New York Times to offer products to Chinese consumers.

Internet regulation illustrates how the Chinese government broadly construes the concept of national security. Anything that undermines the authority or control of the CCP potentially justifies government intervention, even if the economic costs are high. To the extent that the Chinese government enjoys the support of its vast population, this is at least partly due to the country's economic performance. ${ }^{13}$ To continue on its successful trajectory and achieve the Party's 'two centenary goals' of becoming a 'moderately well-off society' by 2021 and a 'completely developed country' by $2049,{ }^{14}$ the Chinese economy must develop or acquire the latest technology. ${ }^{15}$ The government is therefore extremely sensitive to various kinds of economic disruptions that go beyond more traditional security concerns such as energy security or food security. Thus, measures from Washington that constrain China's technology sector only provide greater incentive for Beijing to strengthen many of the policies that unsettled the United States in the first place. ${ }^{16}$ 


\section{Conceptualising the Technology Security Dilemma}

A 'security dilemma' describes a dynamic in which actions taken by one actor to increase its own security are perceived to have the zero-sum impact of reducing the security of another actor. ${ }^{17}$ For example, I buy a gun to defend myself. My neighbour, unsure of my intentions, buys a weapon herself, in turn feeding my own insecurity. A rich vein of security studies scholarship posits that, in the anarchic international system, even non-aggressive actions by one state seeking to bolster its security can be perceived by another as decreasing its own. Given the absence of a global sovereign to police and enforce rules, states must guard their own security and question the present and future intentions of others. ${ }^{18}$ Under these conditions, relations between two states with peaceful objectives can descend into a spiral of mutual suspicion, mistrust, arms races, and even war.

The concept of 'security' in the traditional dilemma focuses on military power - defence against physical attack and limiting the possibility of domination by coercive military force. Yet the events of 2019 remind us that national security can mean much more, especially to the United States and China, which are now engaged in what we call a bilateral 'technology security dilemma'. Each side is taking measures in the technology domain that it deems necessary and legitimate to safeguard its national security, triggering a spiral of tit-for-tat reactions fuelled by mutual insecurity. Below, we offer two examples of these dynamics.

The firstis in semiconductor trade. ${ }^{19}$ Despite vigorous efforts to bolster its semiconductor industry over recent decades, China's manufacturing sector remains heavily reliant on advanced chips from the United States and other developed markets, importing approximately ninety percent of its needs annually. ${ }^{20}$ In a bid to end that dependence, China has employed a raft of measures, including three that sit at the heart of US concerns about ‘economic aggression’: industrial policies, including 
multibillion-dollar funds for the development of integrated circuits; foreign acquisitions; and, allegedly, industrial espionage. ${ }^{21}$ The US government perceives all three of these activities as threats to its national security. The United States objects to the first two because of potential military applications and because it fears ceding technology leadership to a peer competitor. As for

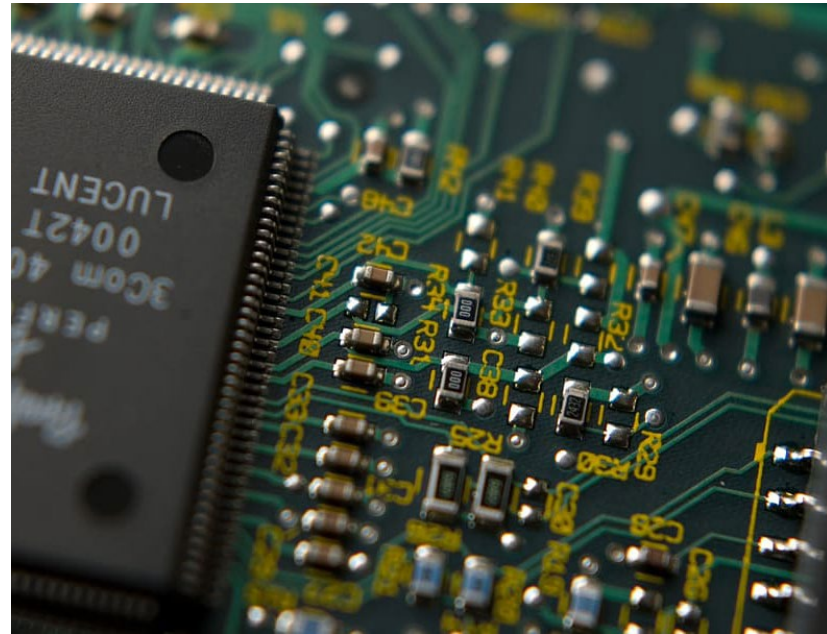

Technology: the security dilemma Photo: pxfuel

the third, the United States perceives such theft as being at odds with global rules, damaging to its own ability to control and profit from American technological innovation and, for some technologies, a direct security concern.

As noted above, the United States has responded by blocking acquisitions, issuing indictments, and banning US companies from trading with Chinese chipmakers, including ZTE (in April 2018) and Huawei (in July 2019). The Trump administration has wound back or delayed some of these measures, but they continue to have serious impacts on companies such as ZTE, which some claim would have folded had Trump not lifted his three-month ban on the company in July 2018. ${ }^{22}$ Huawei's future remains unclear, and other firms are reeling, ${ }^{23}$ though patriotic consumers in China are reportedly ditching their iPhones for Huawei smartphones. ${ }^{24}$ But the sanctions are not having the intended effect. Rather than reining in the behaviour that Washington deems threatening, the Chinese government has doubled down on its quest for self-sufficiency. ${ }^{25}$ This, 
in turn, reignites US concerns, exemplifying the spiral dynamics of a security dilemma.

A second example of the technology security dilemma arises from the links between the Chinese state and China's key technology firms. Part of China's growth strategy is to build and support 'national champions', encouraging them to 'go out' and compete in international markets. Such state support - which can take the form of subsidies, loans, and cheap finance - is a central pillar of MIC 2025. ${ }^{26}$ Huawei is the perfect example of a national champion. Though Huawei is privately owned, state support has helped it grow to become a global industry leader in $5 \mathrm{G}$ and telecommunications infrastructure. ${ }^{27}$ But influence over such companies that the state exercises in return raises the prospect that Beijing could direct a company such as Huawei to do its bidding - for example, by using its technical capabilities to spy on targeted foreign actors or entities. ${ }^{28}$ The close links between Chinese technology firms and the state, and indeed the possibility that national champions with global operations might one day become Trojan horses for surveillance and interference, have generated national security concerns for the United States and allies such as Australia, explaining their reluctance to allow Huawei to run their $5 \mathrm{G}$ networks. ${ }^{29}$

Some Western commentators have described measures to deny Chinese technology firms market access as efforts to 'cripple' or 'crush' them. ${ }^{30}$ As with semiconductors, China's response has largely been to boost its support for national champions - reasserting the central role of the state in the economy, consolidating state-owned and private enterprises in strategic areas, ${ }^{31}$ and further supporting leading firms in a range of technology sectors, from $5 \mathrm{G}$ to artificial intelligence to semiconductors. ${ }^{32}$ As the connections between the state and Chinese tech firms increase, so do security fears among Washington and its allies.

These dynamics present daunting challenges for policymakers. The literature that deals with military security dilemmas suggests that, if the competing states want to break the cycle, they need to reassure each 


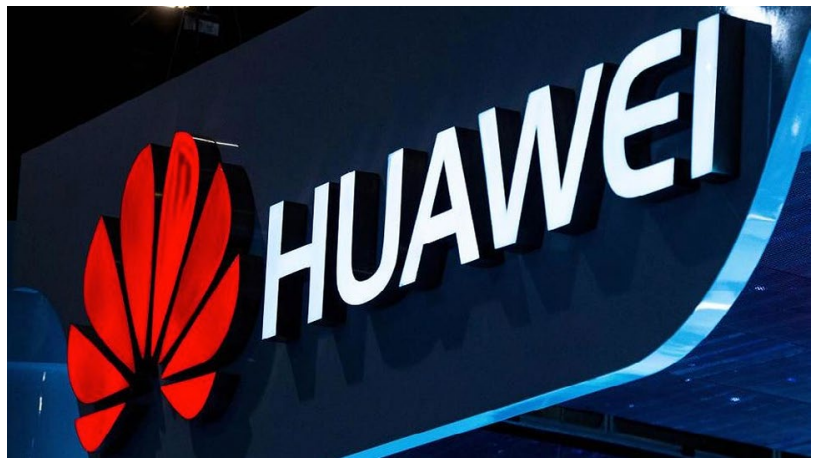

other about their own non-aggressive intentions. ${ }^{33}$ The challenge is to apply these insights to the technology sphere. What, for example, is the analogue of an arms control agreement in the trade and investment space as it relates to the development and use of new technologies? How can each side be made to feel more secure in this issue area?

\section{Pathways to Reassurance}

Both Washington and Beijing need to understand the reasons for the other side's insecurity in the technology domain and take steps to relieve these concerns. For Washington, this would mean recognising Chinese worries about reliance on foreign - in particular, American - suppliers of core technologies and components such as semiconductors. Speaking in 2016, President Xi Jinping stressed that 'the fact that core technology is controlled by others is our greatest hidden danger' ${ }^{34}$ Discussing AI in 2018, Xi similarly emphasised the need to reduce 'external dependence for key technologies and advanced equipment'. ${ }^{35}$

How might the United States provide reassurance regarding these concerns? It could try to send a credible signal that it will not interfere with the operation of global markets that supply Chinese firms. This would see the US government revive the tradition of what John Ikenberry 
calls 'strategic restraint': binding itself more tightly to institutions that would limit its ability to exercise power over markets and international supply chains. ${ }^{36}$ This would likely require the United States to agree to be bound by some kind of enforcement mechanism, akin to the World Trade Organization's compulsory dispute-settlement regime, and invite third parties, such as the European Union and Japan, to monitor and enforce compliance. Given the current scepticism towards multilateral institutions displayed by the White House, an alternative would be to bind itself with domestic institutions - that is, pass laws through Congress to provide greater clarity and transparency regarding any market interventions on grounds of national security.

On the other side of the Pacific, reassurance would similarly involve the Chinese government acknowledging Washington's own concerns, including that with regard to the link between the state and firms such as Huawei, ZTE, Tencent, and Baidu ${ }^{37}$ Exploring credible ways through which Beijing could limit state influence over these companies might send reassuring signals to Washington. For unlisted companies such as Huawei, a public listing on a US stock exchange, which subjects the company to stringent reporting requirements, might be an effective confidence-building measure. Steps to increase transparency regarding

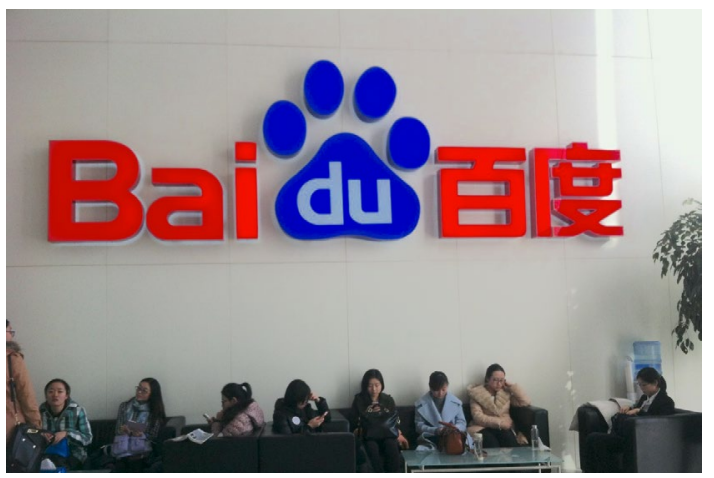

There are concerns in

Washington about the link

between the Chinese state and

companies such as Baidu

Photo: Jon Russell Flickr 
such companies' governance structure and operations, such as agreeing to submit to Organisation for Economic Co-operation and Development (OECD) reporting standards and install independent directors, might also prove effective. ${ }^{38}$ Licensing locally developed Chinese technology for use by non-Chinese firms - an idea recently floated by Huawei's founder Ren Zhengfei 任正非 with regard to 5G - might also enable Chinese companies to continue growing and competing in Western markets without raising undue concern. ${ }^{39}$

\section{Conclusion}

These pathways to reassurance are not necessarily realistic policy proposals given the current state of bilateral relations between China and the United States. But they do help illuminate our diagnosis of the technology security dilemma. Our argument is that decoupling, and the damage it could impose on the global economy, results from mutual insecurity. To arrest this alarming trend, policymakers in Washington, Beijing, and other capitals caught in the crossfire must find creative solutions to make both sides feel more secure.

If neither side is willing to be proactive in seeking to reassure, it is likely that the process of decoupling itself will alleviate some of these pressures over the medium to long term. What has already happened in the online world might point the way. ${ }^{40}$ To the extent, for example, that decoupling forces Chinese companies to develop fully independent technology supply chains, vulnerabilities generated by US export controls and other restrictions will dissipate. And if Chinese and American technology companies were to be completely shut out of each other's markets, and those of states falling within each side's sphere of influence, concerns about what those companies might do on behalf of their national governments will similarly recede. 
Such broad changes may occur due to continuing government efforts to regulate bilateral trade and investment. ${ }^{41}$ At the same time, actors in the private sector may independently decide to reduce their exposure to political risk in foreign markets or other uncertainty created by strained bilateral relations. US firms may even do so because China's cost advantage is diminishing over time as labour costs and regulations increase. At the time of writing, some estimates suggest that, since the advent of the trade war, approximately thirteen percent of US companies with operations in China have shifted or plan to shift some or all of their activity out of the country. ${ }^{42}$

There is perhaps a middle ground between the devastating longterm costs of decoupling and the leap of faith required by reassurance. The two major powers could engage in a focused dialogue about the areas in which they feel most vulnerable to take steps towards mutual reassurance. Brookings Institution Senior Fellow Thomas Wright suggested as early as 2013 that one area in which such an arrangement might prove valuable is information technology and telecommunication networks. ${ }^{43}$ Mutually limiting access to specific industries in that space or others that involve 'critical technologies' would be a good first step. ${ }^{44}$ Other areas of economic interdependence that are mutually beneficial and not perceived to create significant vulnerability, such as agriculture or merchandise trade, might then continue unimpeded, avoiding a costly, full-scale unwinding of supply chains. ${ }^{45}$ Such an agreement would produce a form of 'selective decoupling"46, or what others have called 'managed interdependence' ${ }^{47}$ This 'conscious decoupling' could be formalised in a treaty - an economic equivalent to the strategic arms limitation treaties negotiated by the United States and the Soviet Union in the 1970s.

There are obvious difficulties, however. For example, even if areas of potential insecurity are identified, the challenge would be to agree on mutually acceptable rules, and on establishing a mechanism to enforce them. This would require the dedicated, ongoing, and creative 
involvement of third parties. Given such high stakes, one would hope that all parties could overcome their likely insecurities about the process itself, to avoid an outcome that will ultimately benefit so few. 


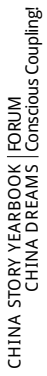


论坛 

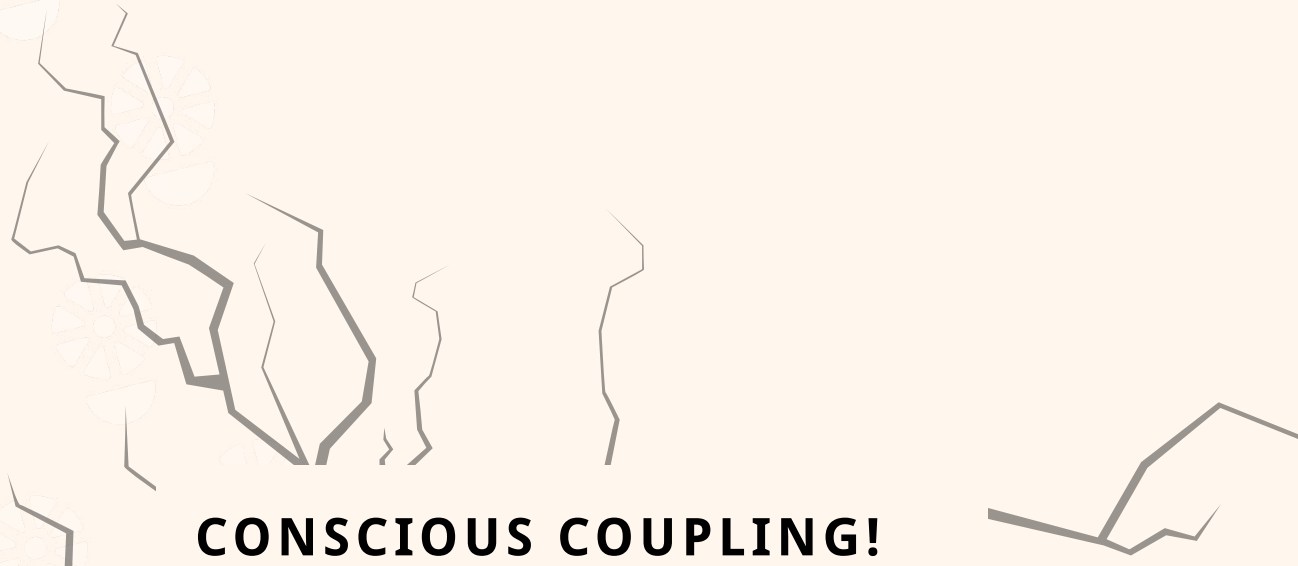

Queer Dreams

- JAMIE J. ZHAO
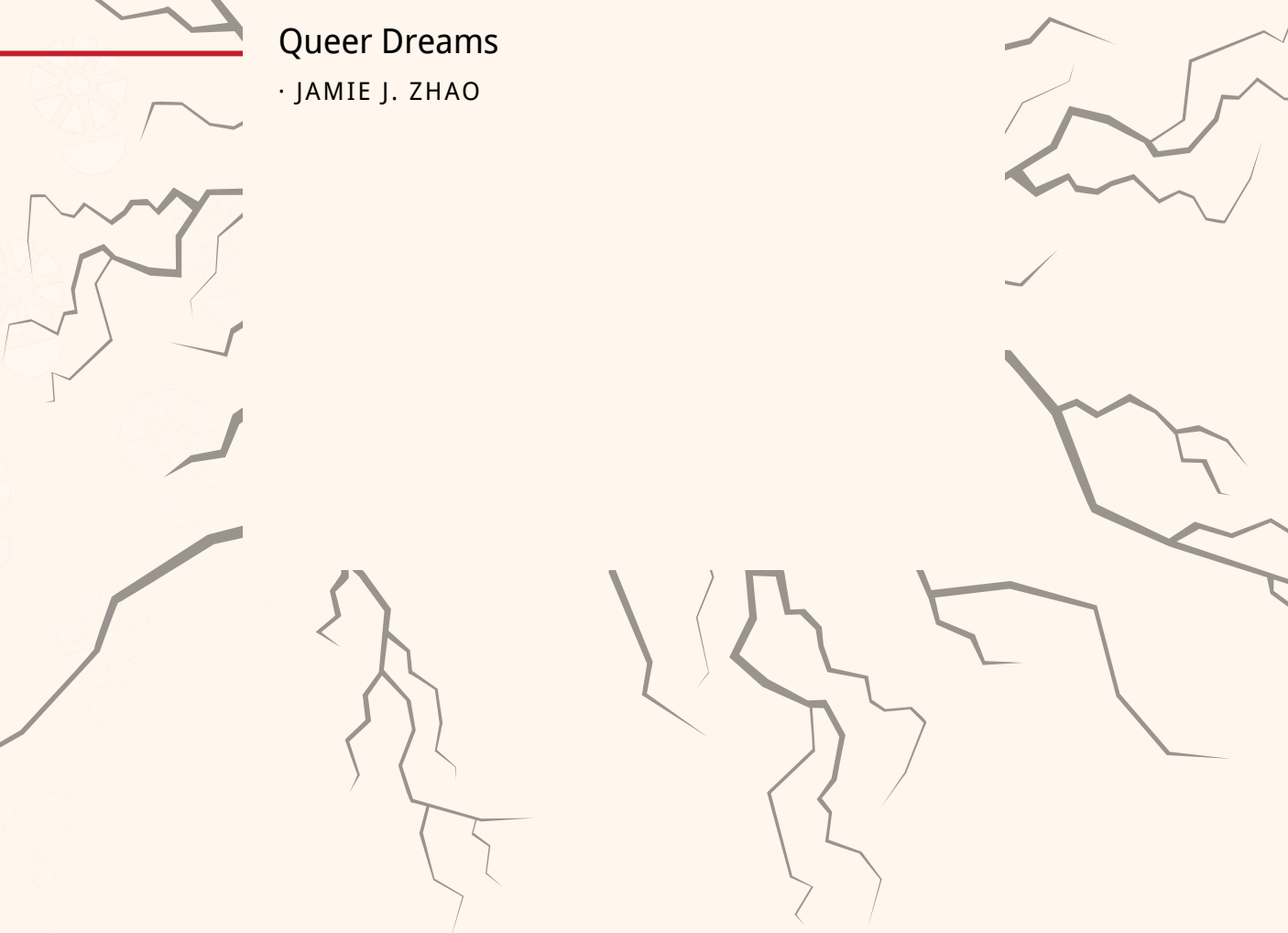


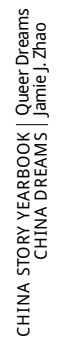




\section{QUEER DREAMS
Jamie J. Zhao}

$\mathrm{T}$

HE PROMOTION OF the China Dream has had an increasingly visible, ambiguous, and complex impact on LGBTQ-related public discourse in China, and on the LGBTQ community itself. This was especially evident in 2019, when elsewhere in the Chinese-speaking world there were significant breakthroughs regarding both legal and political rights for LGBTQ people. On 17 May 2019, Taiwan became the first country in Asia to legalise same-sex marriage. On 30 May, the Hong Kong High Court overturned four laws that criminalised behaviour (such as anal sex) that was illegal only when carried out by gay men; it also revised three other laws. ${ }^{1}$ This progression of LGBTQ legal rights has enhanced the global reputation of both places for their sociocultural openness. In mainland China, homosexuality was decriminalised in 1997 and depathologised in 2001. While a realisation of mainland China's own 'queer dreams' would help to promote a 'positive and inclusive discourse' domestically and benefit its global soft power, ${ }^{2}$ throughout the 2010s, the Party-state was ambivalent in both rhetoric and action.

The Party-state's approach to including LGBTQ within the China Dream combines nationalism, Chinacentrism, cosmopolitanism, and neo-liberalism. For instance, on 18 May 2019, in an English post on Twitter (which has been blocked in mainland China since 2009), the party newspaper People's Daily celebrated Taiwan's move towards LGBTQ rights with a 'Love Is Love' GIF. ${ }^{3}$ At the same 


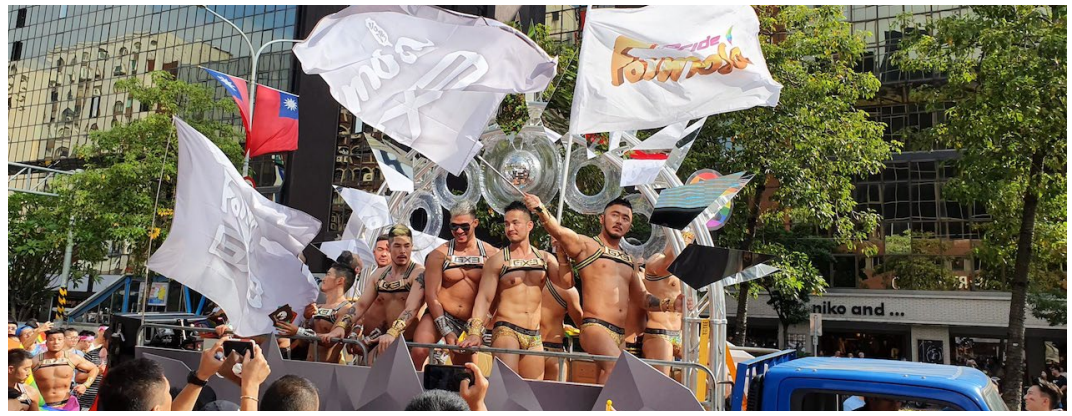

2019 Taiwan Pride Parade

Source: Ben Hillman

time, it attributed the decision to 'local lawmakers in Taiwan, China', subtly 'owning' legislation that applied only to same-sex couples in Taiwan, while asserting Beijing's claim of sovereignty over the island. ${ }^{4}$ This was not the first time the People's Daily had attempted to elevate China's global status and promote national unity by alluding to LGBTQ rights. Back in April 2018, the online People's Daily's 'Strong Nation Forum' published a commentary that criticised Weibo's censorship of homosexual content. ${ }^{5}$ However, the commentary - while implicitly depicting China as a socioculturally inclusive and diverse nation - also explicitly urged LGBTQ people to be well-behaved, socially responsible citizens. ${ }^{6}$ These sorts of official statements, circulated on both local and foreign social media, appear to be aimed more at bolstering China's sociopolitical harmony than defending LGBTQ rights.

A major advance in LGBTQ rights in mainland China in recent years is the extension of officially notarised guardianship agreements to same-sex couples. China's new legal guardianship system, in which 'all adults of full capacity are given the liberty of appointing their own guardians by mutual agreement', was amended by the National People's Congress in March 2017. ${ }^{7}$ This was followed by the approval of same-sex guardianship by the Notary Office of Nanjing in late 2017 and then by the notary offices of Changsha, Chengdu, Guangzhou, Shanghai, Xiangyang, 
and Beijing in August 2019. ${ }^{8}$ While the Party-state has no intention of legalising same-sex marriage, the notarisation can be understood as part of the government's commitment, given in March 2019, to comply with the UN Human Rights Council's five anti-discrimination recommendations on LGBT+ issues. ${ }^{9}$

Since 2015, various LGBTQ communities in Shanghai have staged annual film events - the ShanghaiPRIDE Film Festival (ShPFF), CINEMAQ, and Shanghai Queer Film Festival - despite media censorship of homosexual content deemed to be promoting 'vulgar' or 'abnormal' content. ${ }^{10}$ In the case of the ShPFF, collaboration with foreign consulates enabled it to evade censorship. ${ }^{11}$

According to Bloomberg, there exists a US\$300 billion 'rainbow economy' for LGBTQ merchandise in major cities such as Beijing, Shanghai, and Chengdu, as well as in Chinese cyberspace. ${ }^{12}$ There has even been a burgeoning 'glocalised' drag ball culture in Shanghai since the middle of the past decade. ${ }^{13}$

This surge and celebration of LGBTQ consumerism and culture coexist uneasily with the government's smothering of agitation for greater gender and sexual equality, which challenges China's hetero-patriarchal sociopolitical system and traditions of sexual morality. ${ }^{14}$ The Party-state clamps down on displays of rainbow signs or queer activist slogans in the mass media as well as on online shopping sites, and censors explicit scenes of homosexuality in imported movies (such as Bohemian Rhapsody), as well as feminist social media accounts and hashtags, such as \#MeToo. ${ }^{15}$

This set of mixed policies allows politically innocuous LGBTQ-centred media and popular cultures to exist, and helps to promote a seemingly open-minded image to audiences both at home and abroad, while keeping more serious debates on human rights out of the public space. ${ }^{16}$ By managing 'queer dreams', the Partystate effectively neutralises the potential of these dreams to transform society while turning them into useful elements in China's self-portrayal as a great modern nation on the global stage. 


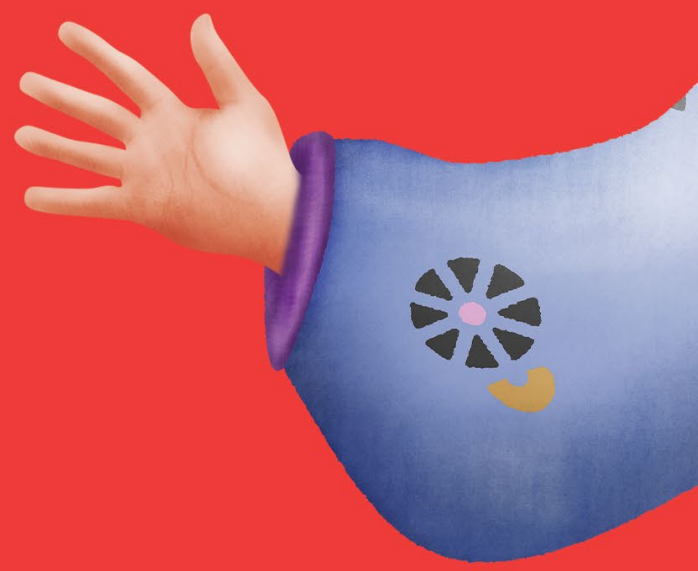




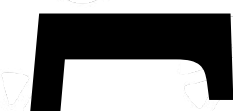




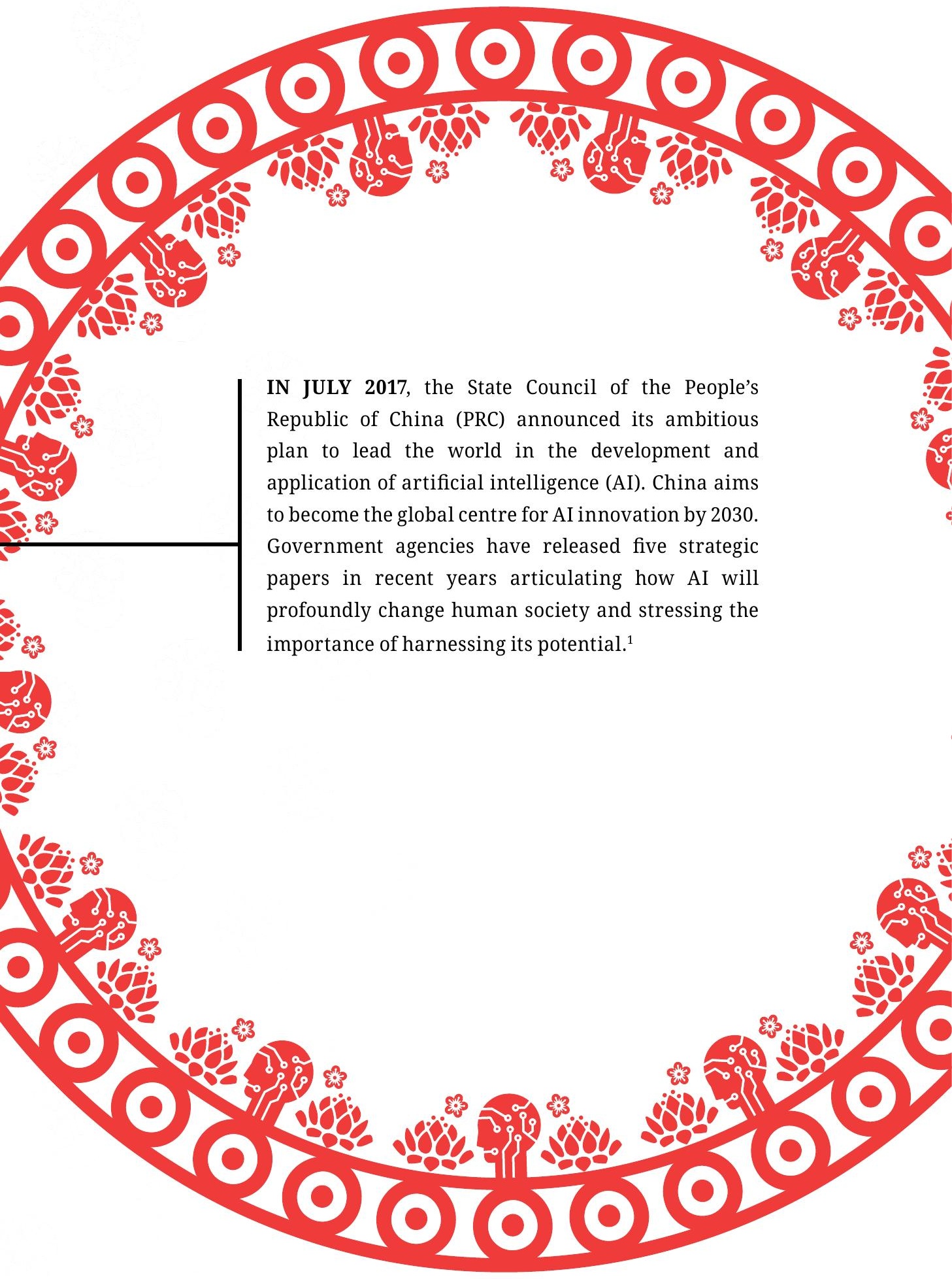


China's ministries, local authorities, companies, and the scientific and academic communities are underwriting its AI ambitions through extensive financing and political support. Meanwhile, state media is helping popularise AI in the public consciousness, linking it to China's continued prosperity and modernisation. Citizens are starting to see the benefits of AI throughout the economy, from smart devices and robots that provide daily conveniences to autonomous vehicle trials easing congestion in major cities. Unsurprisingly, the Chinese are more optimistic than other nationalities about the potential for AI to do good. ${ }^{2}$ They also appear to be confident in China's AI capabilities, with fifty-five percent believing they are already leading or leapfrogging ahead of other countries in AI development. ${ }^{3}$

\section{The Dark Side of AI}

On the darker side of China's AI ambitions are efforts to harness AI for public security. The Chinese government has not been shy about experimenting with AI for authoritarian ends. This is starkly evident in Xinjiang province, where the government's Strike Hard Campaign 严厉打击暴力 恐怖活动专项动 is turning Xinjiang into a testing ground for the use of innovative technologies for social control. Facial recognition, machine learning, natural language processing, and genetic profiling allow authorities to keep the community in check with unprecedented efficiency, scale, and secrecy. More than one million Uyghurs and Kazakhs have been sent to 'political education' camps, many of them arbitrarily detained for activities that are by no means illegal under Chinese law ${ }^{4}$ (see Chapter 7 'Schemes, Dreams and Nightmares: China's Paradox(es) of Trust', pp.199-211).

To domestic constituents, China's government promotes AI as an accurate scientific tool for monitoring and preventing security threats and unrest. The State Council's 2017 New Generation Artificial Intelligence Development Plan declares: 
AI technologies can accurately sense, forecast, and provide early warning of major situations for infrastructure facilities and social security operations; grasp group cognition and psychological changes in a timely manner; and take the initiative in decision-making and reactions - which will significantly elevate the capability and level of social governance, playing an irreplaceable role in effectively maintaining social stability. ${ }^{5}$

This faith in AI may be misguided. As the saying goes, 'Garbage in, garbage out'. If an AI system is built on biased assumptions or poor data, it is likely to codify existing prejudices and inequalities or generate inaccurate results.

Relying on AI in security and law enforcement settings can have its pitfalls. In London, recent trials of live facial recognition by the Metropolitan Police produced inaccurate matches ninety-six percent of the time. ${ }^{6}$ In the United States, AI algorithms deployed to predict crime have discriminated unfairly against African Americans because the systems are trained using historical crime data collected by police with a record of targeting minorities. ${ }^{7}$ Biased AI systems are prone to error, overlooking or misidentifying security threats because the algorithms have been trained to look for the wrong indicators. In the Strike Hard Campaign, authorities are directed to collect information about suspicious individuals. However, many of the behaviours that are deemed suspicious are either integral to the Islamic faith (for example, collecting money for mosques, going on Hajj) or innocuous activities (curiously including welding and using too much electricity, as well as spending time abroad). ${ }^{8}$ Such inherent biases create a pernicious feedback loop. Muslims, welders, and frequent flyers are more likely to be flagged as security threats and investigated, which then validates subjecting these groups to even more invasive monitoring. Far from being neutral tools, algorithms are what AI ethicist Cathy O’Neil calls 'opinions embedded in code'. ${ }^{9}$ 
The Chinese government has a vested interest in presenting AI as scientific, precise, and unimpeachable. If it portrays AI as an objective guarantor of security and other public goods, its citizenry can trust that AI will only harm those individuals who deserve it - criminals, terrorists, separatists, cheats, and other social undesirables. This narrative has been powerful in justifying mass surveillance. China's first national video surveillance program, Skynet 天网, is based on a Chinese idiom about the inescapability of justice (天网恢恢, 疏而不漏 — 'heaven's net is wide, but nothing escapes it'). State media calls the system 'the eyes that safeguard China' and claims it has helped police make numerous arrests. ${ }^{10}$ Ironically, 'Skynet' is the name of the superintelligence in The Terminator movies that is intent on destroying humankind. China's Skynet is no killer robot, but the potential for repressive uses of AI is growing as Beijing rapidly expands its surveillance apparatus and access to citizens' data.

\section{Big Data Gets Bigger}

From 2020, two programs due for completion will combine to collect and aggregate a massive trove of information about Chinese citizens, their movements and their behaviours. The first is Skynet's successor, Sharp Eyes 雪亮 (literally, 'snow-bright'), which will blanket all key public places

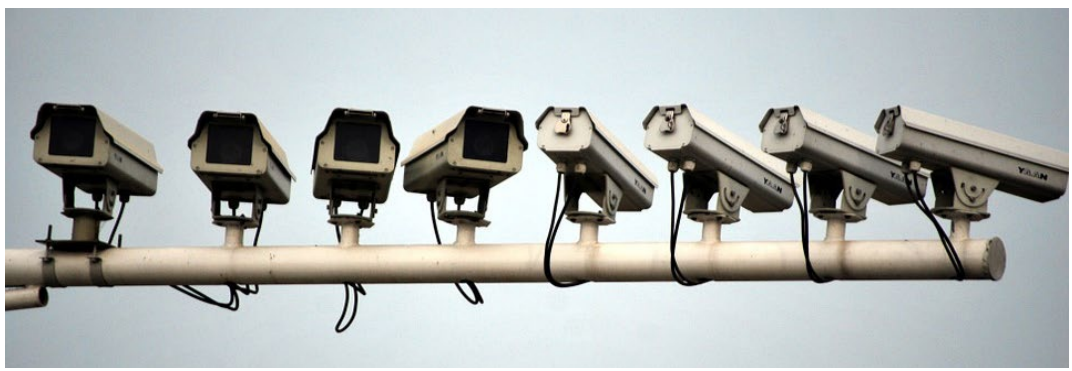


and major industries with live surveillance cameras. ${ }^{11}$ Like Skynet, the name of the program is deliberate and symbolic. 'Sharp Eyes' derives from a Cultural Revolution-era saying, 'the eyes of the masses are bright as snow' 群众的眼睛是雪亮的, which encouraged people to snitch on political subversives. It is a chilling reminder of a time when neighbours and relatives denounced one another for party disloyalty ${ }^{12}$ (see also Chapter 2 Forum 'Xi Jinping's War on "Black and Evil”', pp.43-46).

The year 2020 will also see the national rollout of the Social Credit System that tracks the trustworthiness of companies, government agencies, and citizens. Social credit metes out punishments and rewards based on compliance with government regulations and court orders, among other metrics for good citizenship. The worst offenders are added to a blacklist; the most compliant are added to a 'red list'. The system requires regulatory agencies and companies to frequently update information to the lists. ${ }^{13}$

Authorities can also request access to the data that companies collect in the course of delivering products, services, content, and advertising to their customers. Research by the US-based Center for Data Innovation suggests that consumer data quantity is one of the few crucial areas for AI development where China already has an advantage over the United States. ${ }^{14}$ This is partly thanks to China's lead in mobile payment technologies. With an estimated forty-five percent of the Chinese population using mobile payments, including on omniscient applications such as WeChat, information is continuously being digitised as people go about their daily lives. Companies such as Tencent, owner of WeChat, vacuum up data about what people buy, how they communicate, where they travel, the news they read, the charities to which they donate, and the games they play.

Data collection is also increasingly global. Companies such as Global Tone Communication Technology, an offshoot of the Central Propaganda Department, boasts that it gathers ten terabytes of unstructured global data (equivalent to 4,000 hours of high-definition video streaming) through its media monitoring business each day. ${ }^{15}$ The Chinese Academy of Sciences 
estimates that China will hold twenty percent of global data, or forty-four billion terabytes, by $2020{ }^{16}$

\section{Push for Privacy}

In an increasingly data-driven and surveillance-rich world, citizens in many countries are demanding more privacy and transparent uses of their personal information. In 2018, Europe passed the General Data Protection Regulation (GDPR) to enshrine protections for personal data including a right to be free from 'automated processing' by algorithms. The United States is also debating federal data privacy laws, with some states, such as California, pushing ahead with their own versions of the GDPR.

China is grappling with similar concerns and challenges. It is a common misconception that China is devoid of privacy debates or protections. Many netizens were outraged when Baidu founder Robin Li 李彦宏 claimed in 2018 that Chinese were less sensitive about privacy and would exchange privacy for convenience or efficiency. ${ }^{17}$ Following a series of high-profile data breaches and scams, citizens have called for stronger privacy laws in recent years.

The government has responded to those calls, but in a manner that targets unscrupulous businesses while maintaining its own access to citizens' data. In 2016, the National People's Congress adopted the Cyber Security Law, which bans online service providers from collecting and selling users' personal information without consent. A 2018 Personal Information Security Specification, modelled on Europe's GDPR, further establishes national standards for seeking user consent and collecting, storing, and sharing personal data. ${ }^{18}$ So far, the new regulations have been strictly enforced, with government watchdogs cracking down on smartphone applications that illegally or excessively collect users' data. ${ }^{19}$

While companies are constrained from violating people's privacy, the same cannot be said for the government itself. The very Cyber Security Law 


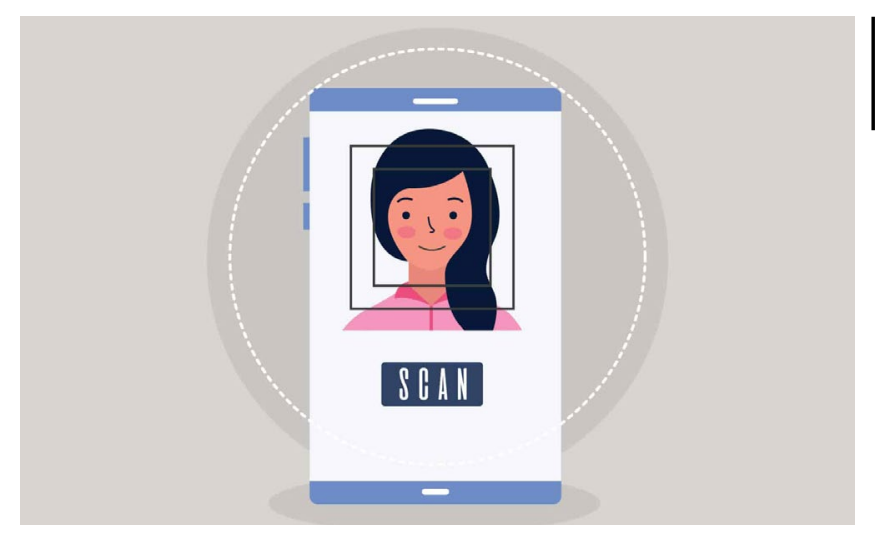

that offers better consumer protections also stipulates that online platforms must provide technical support and assistance to government agencies for the purposes of safeguarding national security and investigating criminal activities. ${ }^{20}$ China's national security laws, particularly the 2017 Intelligence Law, invest security agencies with sweeping powers to ensure that companies cooperate with intelligence work. The Cyber Security Law further cements those powers. New e-commerce laws that took effect in January 2019 also require e-commerce operators to provide data to the authorities when requested, validate users' real identities, prevent illegal content or activity online, and retain transaction information for no less than three years.

The government throws the book at companies that misuse their customers' data or breach their privacy. However, it shows few signs of curbing its own data mining, surveillance, and censorship capabilities, and advances in AI are rapidly expanding those capabilities. The kinds of technologies seen in Xinjiang are becoming the new normal across much of China. Cities such as Suzhou and Weihai have launched 'police cloud' 警务云 databases that use machine learning to parse massive volumes of data about residents for crime prevention and prediction. ${ }^{21}$ Facial recognition is now so commonplace it is used for shaming jaywalkers and dispensing toilet paper in public toilets. ${ }^{22}$ Meanwhile, the Cyberspace 
Administration will soon require social media algorithms to steer users towards online content that promotes 'mainstream values' such as party policies and Xi Jinping Thought. ${ }^{23}$

\section{From Privacy to AI Ethics}

Advances in AI have deepened Chinese concerns about privacy and data. In the 2018 China Economic Life Survey 中国经济生活大调查, jointly run by Tencent's research arm and state media, almost eighty percent of respondents said they thought some applications of AI would compromise their privacy. More than thirty percent also worried that AI would threaten their livelihoods. ${ }^{24}$

In an effort to boost public trust, the government has made a range of commitments to build AI that is ethical and beneficial for society. The State Council's New Generation AI Development Plan includes a goal to establish laws, regulations, and ethical norms for AI by 2025. Beijing has joined the international effort to develop technical AI standards that will also grapple with ethics and safety risks. ${ }^{25}$ In May 2019, the Beijing Academy of Artificial Intelligence and the Chinese Ministry of Science and Technology released the 'Beijing AI Principles', which call for AI to be responsible, diverse, open, and beneficial for humanity. ${ }^{26}$ The principles carry the endorsement of Peking University, Tsinghua University, the Chinese Academy of Sciences, and China's largest tech firms, including Tencent, Baidu, and Alibaba. Encouragingly, the Beijing Principles are broadly consistent with other AI ethics frameworks recently agreed by the Organisation for Economic Co-operation and Development (OECD) and the G20. ${ }^{27}$

These positive signs of China's engagement on AI ethics contrast with China's aggressive use of the same technologies to manage, and in some cases repress, its own people. Yet for China, there is no contradiction. Social management and safeguarding internal security are part and parcel 
of the AI dream. According to the party line, to eschew the capabilities of AI would in fact be unethical. But even if the Chinese population accedes to this argument, international observers are far more sceptical.

\section{International 'Techlash”}

One risk for China is that its use of authoritarian AI leads to an international backlash that stunts its AI ambitions. Western media coverage over the past year has highlighted China's human rights abuses in Xinjiang and Hong Kong, with growing emphasis on the role of technology in enabling those abuses. The ongoing scrutiny has prompted some players in the AI field to restrict research and technology transfers.

In October 2019, the United States added twenty-eight Chinese firms to a list of entities barred from buying American products and components, citing human rights concerns. According to the US Department of Commerce, the new listings specifically target firms involved 'in the implementation of China's campaign of repression, mass arbitrary detention and high-technology surveillance against Uyghurs, Kazakhs, and other members of Muslim minority groups'. ${ }^{28}$ This includes companies such as Hikvision, Dahua, Yitu, and SenseTime - some of the world's largest manufacturers of video surveillance products.

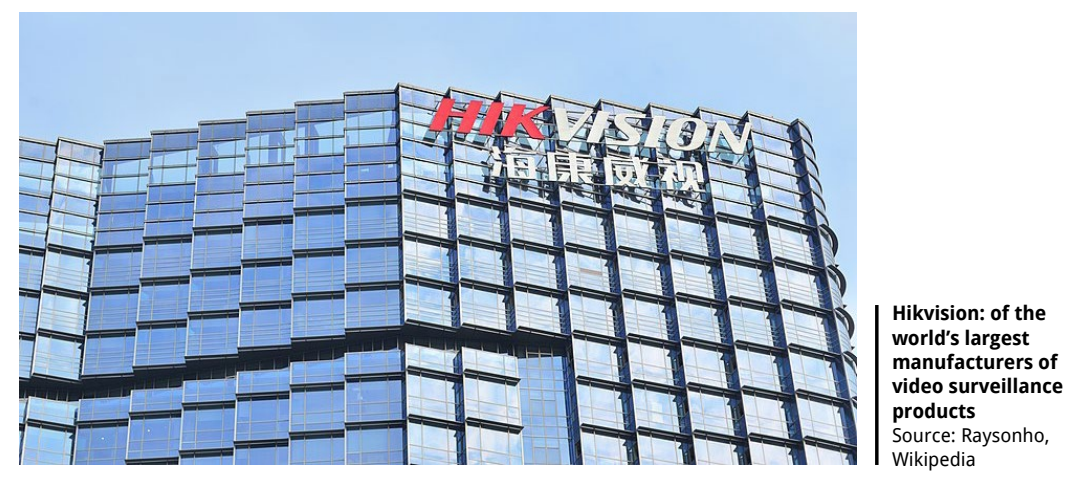


This is the first time human rights have been explicitly declared a US foreign policy interest resulting in the listing of entities. ${ }^{29}$ Some speculate the entities listing was motivated more by US trade war tactics than by genuine human rights concerns, coming as it did on the eve of trade negotiations. Nevertheless, the move amplifies concerns about working with China on new technologies. After employee protests, Google terminated a project to build a censored version of its search engine for the Chinese market. ${ }^{30}$ Bad publicity also forced American company Thermo Fisher to cease selling DNA sequencers to authorities in Xinjiang for genetic mapping. ${ }^{31}$

Ethical considerations are complicated by the fact that many AI technologies are 'dual use'. Beneficial and harmful AI can be almost indistinguishable at a technical level. Prominent American geneticists who have shared DNA samples with China's Institute of Forensic Science have subsequently discovered that their research was used for genetic profiling. ${ }^{32}$ Australian universities have also been implicated, with the University of Technology Sydney and Curtin University forced to review their research approval processes after their academics were involved in projects that may have aided Chinese government surveillance. ${ }^{33}$

Despite impressive investment and progress in indigenous AI development, China still needs global supplies of AI talent and knowhow. With the onset of the China-US trade war, Beijing is particularly sensitive to the risk of overreliance on US producers for critical technological inputs. Crucially, China has not yet succeeded in establishing a local semiconductor industry to produce the chips that power AI computing. ${ }^{34}$ China is also still catching up to the United States and others - albeit rapidly - in terms of quality patents, fundamental research, and attracting international expertise. China files more patents, for example, than any other country but only thirty-seven percent are maintained after five years. ${ }^{35}$ Programs such as the Thousand Talents 千人计划 have not been able to attract the best and brightest scientists and academics to return to China in the long term..$^{36}$ Human rights and reputational concerns are likely to further deter 
foreign talent from working with Chinese firms, conducting joint research, investing in Chinese companies, or sharing data, all of which will also slow the pace of China's AI development.

The government's continued use of authoritarian AI also undermines the credibility of its efforts to influence global standards and governance. It is difficult to imagine countries welcoming China to the global negotiating table while millions of Uyghurs remain in detention. It is equally difficult to imagine China coming to the table for meaningful negotiations with other countries that publicly criticise its human rights record and cut off its supply chains. There are concerns, too, that China is rapidly exporting its authoritarian AI to at least fifty-four countries, frequently packaging the technology into the Belt and Road Initiative. ${ }^{37}$

\section{A Comfortable Panopticon}

China's burgeoning ocean of data, combined with its growing AI capabilities, generates new opportunities and temptations for social control. If China looks set to continue pursuing more authoritarian applications of

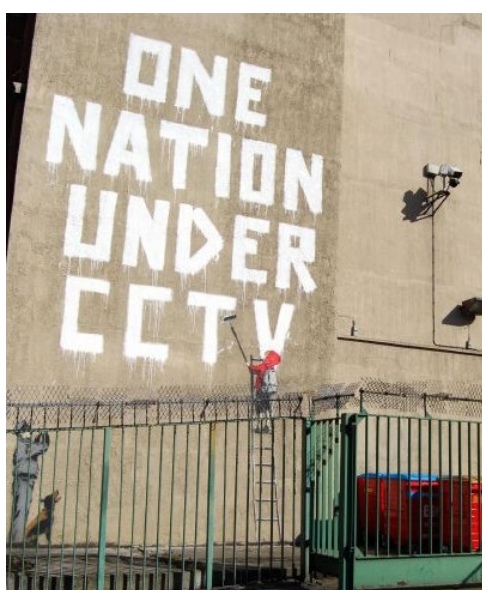

Mural by graffiti artist Banksy in London, 2007

Source: ogglog, Flickr
$\mathrm{AI}$, one key question is how its citizens might respond. Will there come a tipping point where they object?

Ordinary Chinese are not naive. Aware that Big Brother is watching, they tend to moderate their behaviour accordingly. An interesting example of this is the case of Tay, Microsoft's AI chatbot that notoriously began posting inflammatory and offensive tweets just hours after it was launched in 2016. Tay was first tested as Xiaoice 小冰 in China, where it gained a strong following over eighteen months with 
no such off-script moments. One reason for this difference is that Chinese netizens closely follow online rules. They generally do not harass, smack talk, or troll each other because there is always the possibility that the state is listening in. ${ }^{38}$ The online environment thus resembles English philosopher Jeremy Bentham's concept of a 'panopticon' - a prison in which the inmates never know whether they are being watched and are therefore motivated to act as though they are always being watched.

A panopticon might sound chilling to some, but for others it is a comfort. Decades of Communist rule have inured much of the population to government intrusion while coopting them with its benefits. China has a deeply embedded and historical tradition of promoting good moral behaviour. Where fraud, corruption, and cheating are rife, systems that bolster trust and deter wrongdoing are considered necessary and even welcome. ${ }^{39}$ Social credit, for example, is far more controversial outside China than within. The Party-state encourages all its citizens to contribute to systems of community policing. In many rural locations where Sharp Eyes is piloted, locals can tune into the live surveillance feeds and report their neighbours' transgressions. ${ }^{40}$ Hebei province has released a 'debtor map' 老赖地图 app that allows users to blow the whistle on wealthylooking debt dodgers in their vicinity. ${ }^{41}$

Many Chinese accept automated monitoring as a small price to pay for stability, prosperity, and social harmony. Those who follow the rules reap the spoils of an ascending China. Those who step out of line pay the costs. China's dreams of AI development are inextricably linked with the use of AI as a tool for social engineering. If China should succeed at both - vastly expanding its AI capabilities and universally deploying those capabilities towards controlling its citizens - its AI dream could turn into a nightmare for any who dare to dissent. 

论坛 

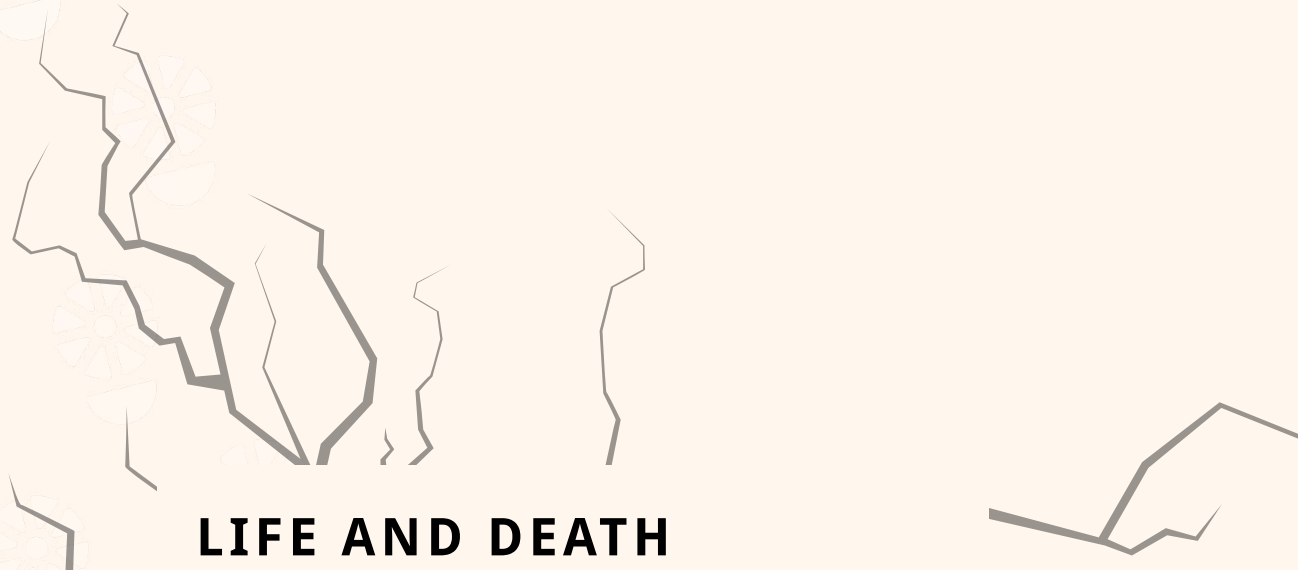

Dream Babies

- JANE BROPHY

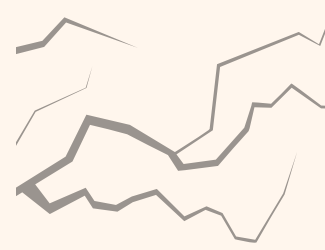

Recurring Nightmare: The Plague Visits Beijing

- JANE BROPHY
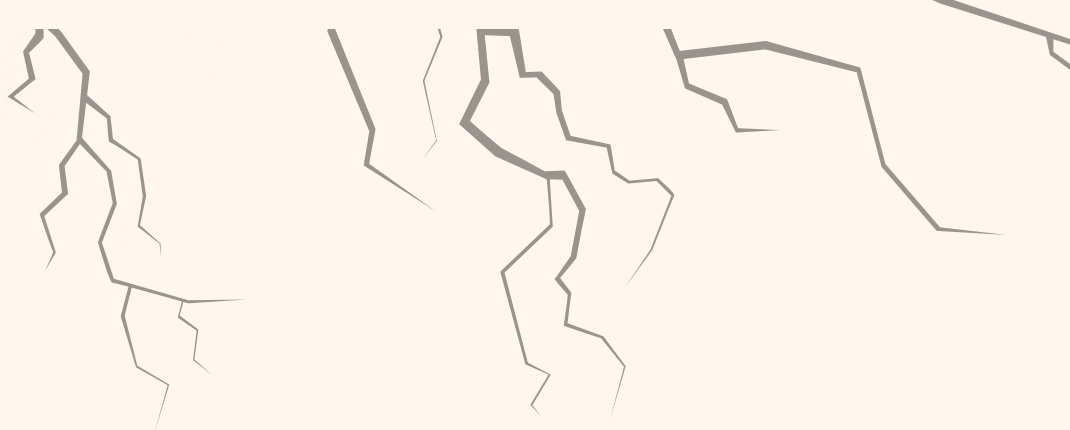


\section{DREAM BABIES
Jane Brophy}

O

N 25 NOVEMBER 2018, two days before the start of the Second International Summit on Human Genome Editing in Hong Kong, a clip appeared on YouTube entitled 'About Lulu and Nana: Twin girls born healthy after gene surgery as single-cell embryos'. ${ }^{1}$ In the clip, He Jiankui 贺建奎, an Americantrained Chinese associate professor of biophysics at Shenzhen University of Science and Technology, stands in his private laboratory (he oversaw a state university lab and founded his own private biotech company lab), speaking in English (with English and Mandarin subtitles). He claimed he had just brought into the world the first genetically edited babies that is, the first babies to have had deliberately induced changes to their germline, which is a series of cell lines descended from previous cells that are passed down through generations of humans. This germline would be inherited by any future children they may produce.

At the summit, organisers quickly rearranged the program so He Jiankui could appear solo to explain himself. To a shocked audience, he revealed that he had represented the experiment to his participants as a study into an HIV/AIDS vaccine, and that they may not have fully understood what they were consenting to. ${ }^{2}$ Later investigations revealed that the ethics committee he cited as overseeing the 'trial' claimed to have no knowledge of it and the paperwork produced as evidence of institutional ethical approval contained an extremely 


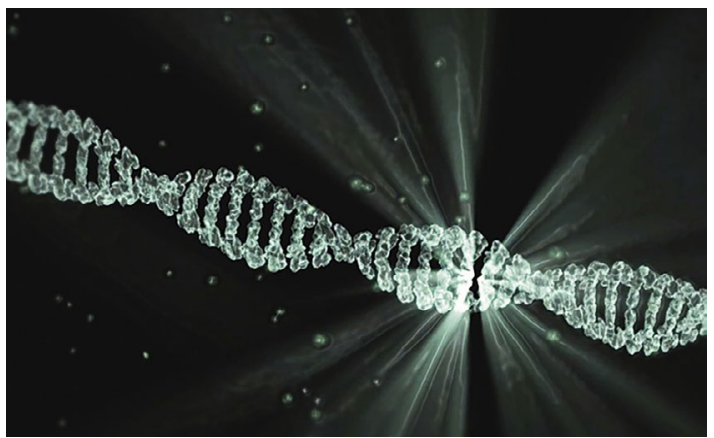

Source: Pixabay

unusual reference to the advancement of the People's Republic of China's (PRC) global reputation for scientific innovation as an ethical justification for the procedures. ${ }^{3}$

A flurry of controversy engulfed the conference, and both Chinese and international attendees were swift in their condemnation. ${ }^{4} \mathrm{He}$ Jiankui had broken many of the rules, but also the norms, of the genomics community. He contravened protocols of how scientific advances are communicated by announcing it via YouTube ${ }^{5}$ and, as George Estreich of Oregon State University pointed out in The Conversation, it was a bizarre announcement, riddled with misleading, emotive, and deceptive language. ${ }^{6}$ Was He Jiankui genuinely interested in scientific advancements or was he just courting publicity? There were a number of glaring holes and inconsistencies in the evidence he provided and the scientific process he described.

Scientists the world over have been investigating the multiple possible applications of a gene-editing procedure, known as CRISPR Cas-9, since the technique was pioneered by American molecular biologist Jennifer Doudna in 2012. ${ }^{7}$ The technique holds much promise for therapeutic genetic editing, which is commonly represented as a 'cut and paste' technique to add or remove genetic markers for conditions that adversely impact one's health, thus curing genetically inherited diseases. It could possibly also be used to create 'designer babies', by altering genetic traits for aesthetic purposes as a matter of preference. Many laboratories are experimenting with its application in human embryos 
in vitro up to fourteen days from creation, which has been agreed by the international genomics community as the ethically acceptable limit. The scientific consensus to date holds that it would be unconscionable to allow any edited embryo to progress through the process of invitro fertilisation (IVF) in a woman, ultimately resulting in a live birth. The scientific, ethical, moral, legal, and social objections for doing so are vast. The arrival of Lulu and Nana brought fresh urgency to the issue of ethical standards in research, which is hotly debated in the international genomics community.

He Jiankui expected to be hailed a national hero in the name of advancing China's dreams of international biomedical leadership. Instead, he was swiftly condemned both locally and internationally, removed from his university appointment, and soon after disappeared from public life. ${ }^{8}$ The end of 2019 saw him sentenced to three years in prison, along with two colleagues, for practising medicine without a licence and 'seeking fame and wealth'. ${ }^{9}$

Prior to this, China had already attracted uncomfortable international scrutiny over the growth of commercial industries selling highly experimental, even unproven, treatments - notably, stem cell treatments. ${ }^{10}$ Despite China's recent attempts to rein in the market for unproven stem cell treatments, He Jiankui's story revealed that the structures of Chinese scientific institutions and enterprises still allow scientists and biotech entrepreneurs to operate away from the regulatory eye. In July, a Spanish scientist employed by the Salk Institute in the United States announced that he had created the first humanmonkey chimera (cells from both species combined in one organism) in a lab in December. This research - purportedly the first step in using animals for human organ transplants - is not permitted in the United States. ${ }^{11}$ The first pigs containing cynomolgus monkey cells were born full-term in December 2019, although they survived for only a week..$^{12}$

Since China's Reform and Opening Up in 1978, increasing numbers of scientists, doctors, biotech entrepreneurs, and patients in search of treatments not permitted in their home countries have travelled there to take advantage of so-called 
regulatory grey areas. ${ }^{13}$ But beyond this, how did China become a favoured home for scientists wanting to push the limits of ethically acceptable scientific innovation?

As the anthropologist Aihwa Ong has argued in her work on biotechnology in Asia:

[B]iotech mechanisms are presented as ethical operations that link the immediate needs of the individual consumer or patient to the political generation of civic virtue, that is, appropriate conduct and social obligations to contribute to national prosperity and security. ${ }^{14}$

If his motives were indeed sincere, He Jiankui might have believed that he was employing a highly technical pathway to enhancing the health and prosperity of his country's population. This would explain why he thought his work would be received positively in China.

As for Lulu and Nana's story, we know very little about the lives of the twins or their parents; however, the father's HIV status is a crucial element in the story. In his commentary on the YouTube announcement, $\mathrm{He}$ Jiankui cites the high level of anxiety experienced by the girls' parents about the possibility of passing HIV on to any child they might conceive naturally. ${ }^{15}$ Couples of whom either one or both of the parents are HIV positive are not allowed to access fertility treatment even if they can afford it. This dynamic was a key part of their willingness to participate in the experiment, which offered them a chance to have a baby who would not inherit the father's virus. He Jiankui offered a procedure that would 'wash' the sperm to prevent transmission from parent to child, while introducing a genetic edit that purportedly would 'switch off' the embryo's ability to acquire HIV. ${ }^{16}$ As he explained in the YouTube video, 'discrimination in many developing countries makes the virus worse'. He rightly pointed out that people living with HIV face discrimination in employment as well as from medical professionals; some women even face forced sterilisation. Precisely because of the plight of people living with HIV in China, some critics considered the way the 'study' was presented to the couple to be a coercive recruitment strategy. ${ }^{17}$

He Jiankui imagines a future in which genetic editing in babies will be considered as uncontroversial as the 
IVF procedure he used to implant the embryos into the mother. He cites the case of Louise Brown, the first baby born through IVF, and argues that 'for forty years, regulations and moral [sic] have developed together with IVF'. But meanwhile, He's 'dream babies' turned into a personal nightmare for him. He lost his lucrative university position, his professional standing, and ultimately his freedom, and his name is now synonymous with the 2019 global reckoning with the ethics of innovation in genomics. The impact of the procedure on Lulu and Nana in the long term remains to be seen. Yet, as He Jiankui hints in the video, it may be just a matter of time before he is vindicated. In May 2019, new regulations were introduced in China stating that anyone who manipulates genes in humans is legally liable for anything that happens to the health of that person. ${ }^{18}$ Yet in June 2019, undeterred by He Jiankui's fate, and beyond China's regulatory borders, a Russian scientist announced his plans to proceed with a genetic-editing procedure that he is now stridently defending from criticism, ${ }^{19}$ and vowing to pursue..$^{20}$ For those dreaming of a future of therapeutic genetic editing and designer babies, that future may be closer than anyone thought. 


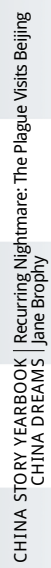




\section{RECURRING NIGHTMARE:
THE PLAGUE VISITS BEIJING Jane Brophy}

Bird flu in the year of the rooster ... swine fever in the year of the pig. Next year is the year of the rat ... the plague is coming.

— Weibo user, November $2019^{1}$

C O WROTE ONE Weibo user in mid$\checkmark$ November after days of widespread rumours in the capital of the People's Republic of China (PRC) sparked panic. Then, the government confirmed it: the thought-to-be eradicated pneumonic plague had arrived in Beijing.

Pneumonic plague, a severe infection of the lungs, is one of three types of plague caused by the bacteria Yersinia pestis (of which there are many strains), the other two being bubonic (found in the lymph nodes and associated with the feared pustules of the 'Black Death' of fourteenth-century Europe) and septicaemic (found in the bloodstream). ${ }^{2}$ The bacteria is endemic in China and, while the bubonic form is more common, pneumonic is the most virulent. Left untreated, it can be fatal within eighteen to twentyfour hours, although if treated quickly and effectively with appropriate antibiotics, it is easily contained. The most common way of contracting the plague in China is through the bite of an infected flea or by coming into contact with (or even consuming) an infected rodent. Pneumonic plague can spread through respiratory droplets from an infected patient who sneezes or coughs, for example. In the southern, central, and western parts of China where the rodent population is high (increasing desertification and drought provide favourable living 
conditions) and rural life makes contact with disease carriers more likely, large public health campaigns since 1949 have been successful in mobilising teams of villagers to engage in pest-control work. Teams of rat catchers still trap and test rats periodically to monitor them for possible outbreaks and changes to the

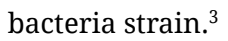

For Beijingers, however, the threat of the plague is a distant memory, as seen in a World Health Organisation (WHO) map of the global distribution of plague in 2016 (see opposite). ${ }^{4}$ Thus the news, first appearing via a quickly deleted social media post by a doctor working at central Beijing's Chaoyang Hospital in early November, revealed that two plague patients had been mysteriously 'transported' from a hospital in Inner Mongolia. ${ }^{5}$ Despite attempts by China's Centre for Disease Control and Prevention (CDC) to limit further public discussion, rumours spread rapidly as the hospital ordered medical students working there to stay at home and all the seating in the emergency waiting area was replaced. ${ }^{6}$ Government attempts to take control of the narrative and quell panic only fuelled it by providing an incomplete picture of what had actually taken place. This revived fearful memories of the mismanagement of SARS ('severe acute respiratory syndrome' or 'bird flu') at the same hospital in 2003, where a lack of public communication is believed to have resulted in the spread of the disease. ${ }^{7}$

Occasional cases of plague infection are not rare in interior parts of China and are only sometimes lethal. But the presence of two infected patients in one of Beijing's premier hospitals sent social media users into fits of panic and made international headlines. ${ }^{8}$ Locals on social media demanded to know more about the circumstances under which the patients were transferred to Beijing: Had the patients been taken by public transport? Had they been on a plane? What steps had health officials taken to prevent the potential airborne spread of the disease?

Further investigative reporting by the English-language media outlet Caixin, which obtained an internal CDC brief, suggested this recent outbreak had been contained. ${ }^{9}$ It revealed that the highly unusual step of transferring the two patients (a married couple) more than 800 kilometres to the capital - when normal protocol is to 


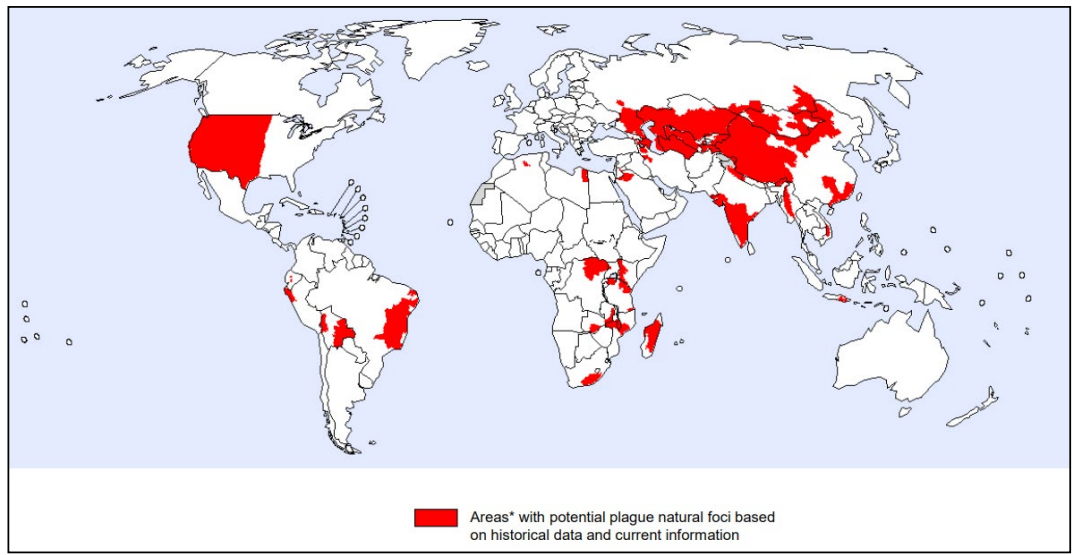

Global distribution of natural plague foci as of March 2016

Source: WHO/PED, as of 15 March 2016

isolate and treat patients as quickly and as locally as possible - was taken because of a delayed diagnosis and the need for more specialised facilities to treat the infection in its advanced stage. $^{10}$ They were, moreover, transferred by ambulance. After their short stay in the emergency department at Chaoyang Hospital, the couple was taken to the smaller Ditan Hospital, which specialises in infectious diseases. The couple's son and daughter were being monitored, and others at the Chaoyang Hospital who may have come into contact with them were being preventatively treated. While all this turned out to be something of a 'storm in a teacup', greater transparency at the outset could have prevented the panic and suspicion.

While the memory of plague might not be so vivid for today's citizens, China has a long history with the bubonic and pneumonic plagues. The third great plague in documented history began in 1855 in Yunnan. The two previous outbreaks were those suffered by the Byzantine empire in 541 and 542 and the Black Death that killed one-third of Europe's population between 1346 and 1353 . Driven by increased global trade and an influx of the ethnic majority Han people seeking to exploit the natural resources of south-western China (where many rats and fleas were carriers of plague bacteria), the 


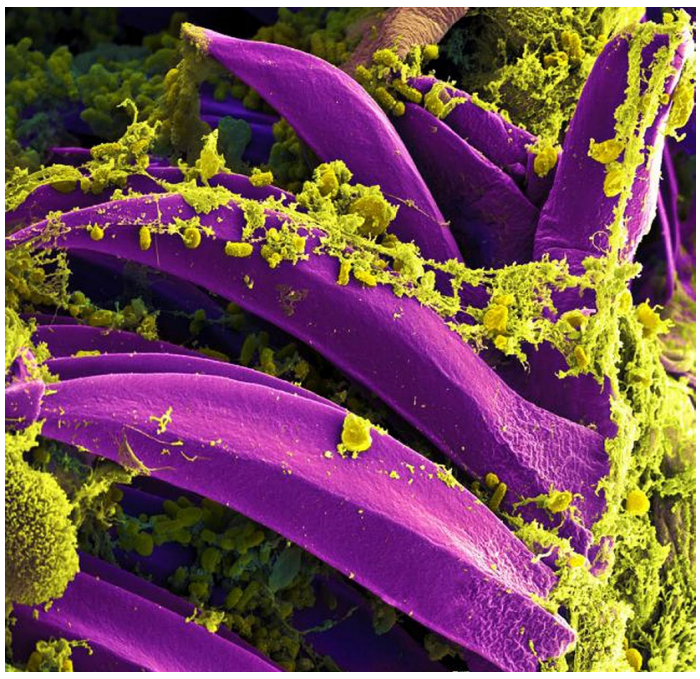

Under the lens: The bubonic plague Source: U.S. Dept. of Health \& Human Services, Flickr

nineteenth-century 'Third Plague' bloomed into a global pandemic of (primarily) the bubonic strain, which was spread by rats and fleas on trading ships. In China and India alone, twelve million people died. The threat was considered active in China until 1960 when cases reported to the WHO fell to below 200 per year. ${ }^{11}$ Despite this, or perhaps because of it, as admitted by health authorities in Inner Mongolia, public health campaigns to raise awareness of plague prevention and control have not been as visible in recent decades. Caixin spoke to residents of Inner Mongolia who were surprised to learn that the plague was an ever-present threat as they had not lived through a public education campaign. ${ }^{12}$

This 2019 case highlighted two uncomfortable truths: the persistent health divide between rural and urban areas, and the potential impact climate change is having on plague control efforts. According to the investigation by Caixin, the couple was from Sonid Left Banner, a country-level division of Xilingol League in remote central Inner Mongolia. They contracted the plague while carrying out pest-control work. In the past fifty years, China has recorded more than 1,000 cases of the plague and 183 deaths, with the hardest hit region being north-western Qinghai. ${ }^{13}$ In May 2018, the Xinhua 
News Agency reported an explosion of the rat population in Inner Mongolia, which it attributed to 'recent persistent drought' and a vague reference to 'climate change'. ${ }^{14}$ For people looking for examples of the interplay between climate change and epidemiological trends around the world, this might represent a new but ongoing challenge to plague eradication. As well as examining rising rodent numbers, a small number of scientific studies have begun to explore the relationship between climate and the plague cycle, suggesting temperature extremes play a factor in increased transmission. ${ }^{15}$
In response to the increased rodent population in 2018, the central government allocated twelve million yuan for pest control in the region, meaning more residents doing the frontline work in direct contact with rodents. The case of the couple from Inner Mongolia suggests that concurrent investment in healthcare infrastructure and resources to protect the health of those workers will be a crucial piece of managing the plague. It remains to be seen whether 2020, the year of the rat, will also be the year that the rat-borne plague returns to Beijing - and beyond. 


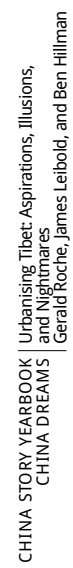




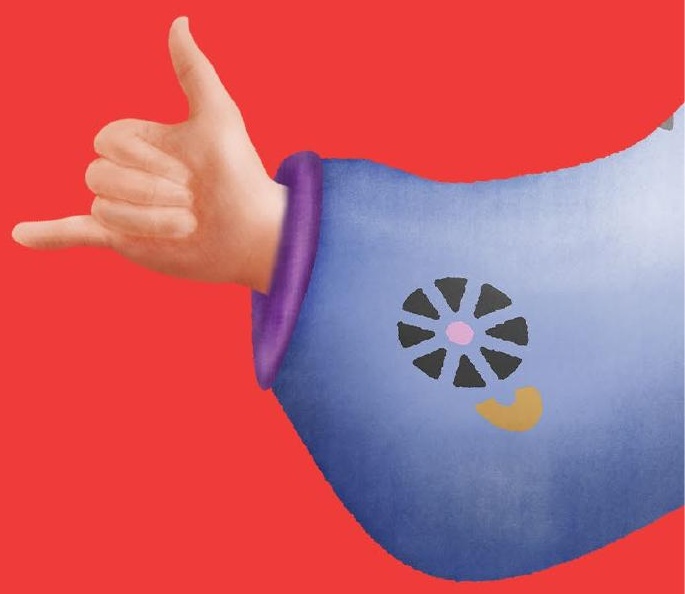




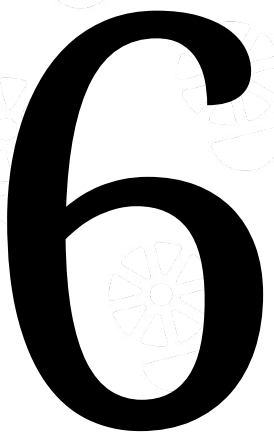




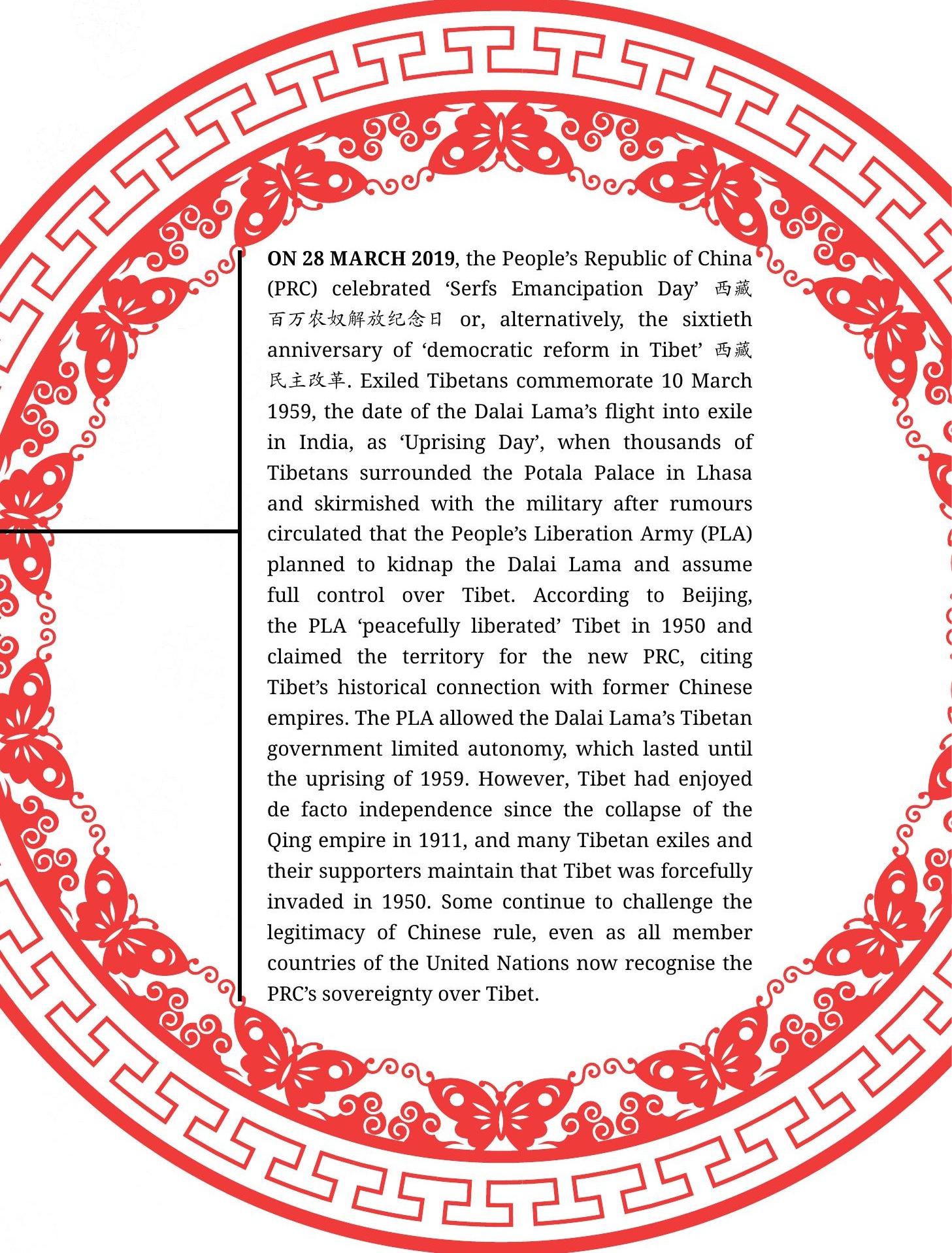


Like much of Tibet's history, the events of 1959 remain contentious, as does the PRC government's record in the Tibet Autonomous Region (TAR), which was established in 1965. Exiled Tibetans and other critics draw attention to human rights abuses, the marginalisation of Tibetans in their own land, and the suppression of religious and cultural practices. ${ }^{1}$ Many Tibetans remain frustrated with policies that constrain religious and cultural expression. ${ }^{2}$

Meanwhile, Beijing trumpets its record in bringing prosperity and improved social systems to the region. Many among China's Han ethnic majority has long viewed Tibetans as culturally backward: superstitious savages who required 'saving' and 'civilising' by the Chinese Communist Party (CCP) to bring them into the modern world alongside the Han. ${ }^{3}$ As state media outlet Xinhua triumphantly proclaimed in March 2019:

Democratic reform has achieved a great leap from the feudal serf system to the socialist system in Tibet. The establishment of the socialist system not only liberated and developed the productive forces, but also promoted Tibet's economic development to a new level, and greatly promoted the overall progress of Tibetan society. ${ }^{4}$

Beijing has long maintained that Tibetan grievances can be best addressed by improving Tibetan living standards and better integrating Tibetans into China's mainstream society and economy. ${ }^{5}$ Since 2001, Beijing has invested more than US $\$ 100$ billion in development projects across the Tibetan Plateau, ${ }^{6}$ and around ninety percent of the budget of the TAR, which was established in 1965, comes from Beijing. ${ }^{7}$ Development policy for the region now centres on urbanisation, which is seen as key not only for economic growth, but also for taming the wild plateau and its unruly inhabitants, and promoting 'ethnic intermingling' 民族交融, including intermarriage. ${ }^{8}$ Urbanisation has emerged as a new tool of multiethnic governance for the CCP - an integral strategy for President Xi Jinping's dream of the 'great rejuvenation' 伟大复兴 and 'communal consciousness' 共同体意识 of the Chinese nation. ${ }^{9}$ 


\section{Urbanising Tibet}

Party officials in Beijing dream of a string of 'civilised cities' 文明城市 stretching across the Tibetan Plateau: urban landscapes of concrete, glass, and steel where Tibetans live, work, and consume much like their Han counterparts in Beijing and Shanghai. Cities are sites of civility and modernity in the eyes of Chinese leaders - places where orderly, rational, and obedient citizens act out the China Dream 中国梦 according to party prescripts. With more intrusive and detailed forms of state surveillance, cities increase the control of the Party over citizens.

The National New-Type Urbanisation Plan (2014-2020) aims to raise urbanisation rates to sixty percent nationally. ${ }^{10}$ This is not just an economic strategy to increase consumption and growth, but also a mechanism for enhancing Party governance. The Thirteenth Five Year Plan specifically targets China's ethnic frontier, including all areas of Tibet, where urbanisation rates are relatively low: 47.1 percent in 2015 compared with the national average of 56.1 percent. ${ }^{11}$ In 2010, only 5 percent of Tibetans permanently resided in a city - an increase of just 6.9 percent over the previous decade..$^{12}$ There are now ambitious plans to boost the urbanisation rate in the TAR to more than thirty percent by $2020,{ }^{13}$ with similar efforts under way across the Tibetan Plateau (which extends beyond the TAR to include Qinghai province and parts of Sichuan, Yunnan, Gansu, and Xinjiang).

Tibetans are shaping their own visions of what urbanisation means for them, including the opportunities and threats cities present for their livelihoods and ethnic identity. These visions, as expressed in popular culture, and pop songs in particular, are far from homogeneous. Three recent Tibetan pop songs, and the rich visual tapestry of their music videos, display a range of Tibetan attitudes towards urbanisation as well as providing an insight into the complex realities of Tibetan urbanisation today. They also evoke ideas of universal relevance to the vicissitudes of urbanisation in other places around the world. 


\section{The Nightmare City}

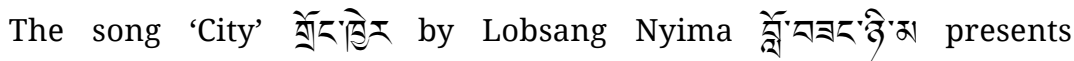
urbanisation as a Tibetan nightmare. The song's video clip opens with the camera hovering above a snow-speckled mountainscape. The Tibetan

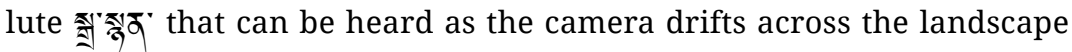
is deep and resonant, combining a Metallica-esque riff with a melody

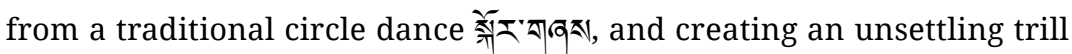
reminiscent of a sprightly dirge. Suddenly, the urban form materialises: an upside-down cityscape occupying the empty space above the mountains. Here, we see the basic theme of the song: the city as the inverse of the rural.

The singer, Lobsang Nyima, was born in the countryside of Ngawa $E^{\prime}$ /Aba 阿坝 county ${ }^{14}$ in the mountainous north-western corner of Sichuan province, which has been a hotspot of ethnic protests and selfimmolations since 2008. While ninety-one percent of its residents are still classified as nomads, the county seat, Ngawa/Aba town, is now home to nearly 12,000 residents, having tripled its population in recent decades.

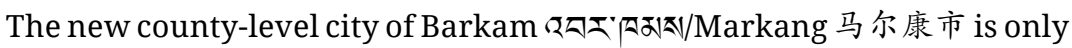

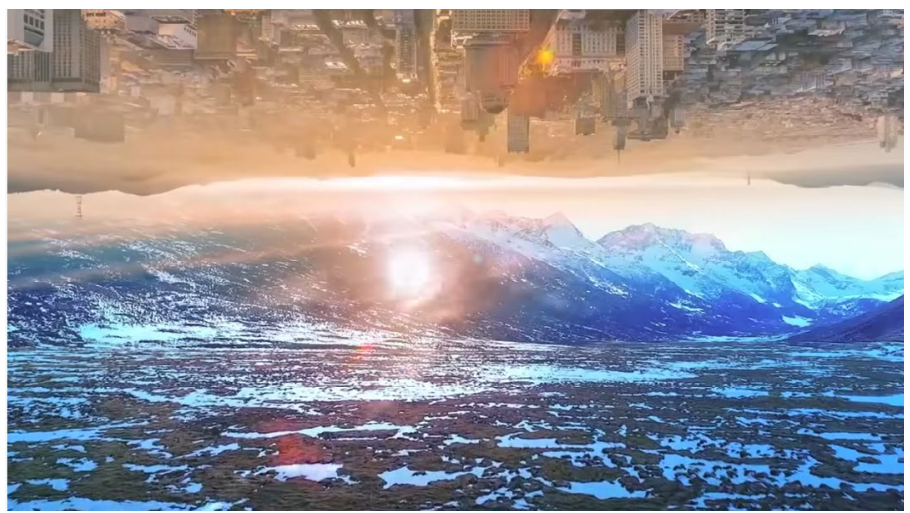

Still from the music video, 'City', by Lobsang Nyima

Source: Tibetan HeartBeat, YouTube 
a couple of hours away by road, and is home to another 60,000 urbanites, who live in high-rise buildings squeezed on to the region's steep, rugged mountains.

The lyrics to 'City' contrast images of rural purity - white clouds, white eagle feathers, and yoghurt - with the pollution of the city. This pollution includes not just the dust, noise, and bustle of the city, but also social pollution - the ways in which the city corrodes trust between people, leading to spiritual and emotional suffering. The singer laments losing his 'mind' स्रेइत्र and his capacity to love in the urban milieu.

The video follows the singer on his downward spiral through pollution and loss, from arriving in the city in his traditional robes to donning a leather jacket, getting drunk, and becoming violent and disoriented, before returning to his rural homeland, perched atop a mountain ridge, wistfully surveying the landscape. Equating the city with the sufferings of 'worldly existence' (from the Sanskrit samsāra), this idyllic return to the homeland seemingly equates the rural not just with freedom, but also with mastery of the self.

Decades of research by Indigenous scholars in settler-colonial states such as Australia, the United States, and Canada have shown how Indigenous peoples have been discursively erased from the city because their cultures are portrayed as being 'incongruous with modern urban life'. ${ }^{15}$ To portray Indigenous people as fundamentally rural is to justify their exclusion from cities and their containment in rural spaces. Since the mid twentieth century, Indigenous social movements around the world have asserted the right of Indigenous people to inhabit urban spaces and claim them as their own. ${ }^{16}$ Therefore, while Lobsang Nyima's song evokes the ways in which state-led urbanisation negatively impacts Tibetans, it also reinforces a problematic romantic binary in which 'authentic Tibetanness' is rural and traditional, while the urban and modern are antithetical to it; Han space can only corrupt, erode, and destroy Tibetan culture and identity. 


\section{The Aspirational City}

The contrasting images of rural purity and urban pollution are challenged by one of the most popular Tibetan pop songs in recent years, 'Fly' 젖ㅈ, by ANU drums make for an irrepressibly upbeat song (think Avicii, but Tibetan). When the city first appears in the video clip for this song, the singer is standing on a mountain top, arms spread, the city far below him. Similar images are repeated throughout the video, showing the city as something to soar above and tower over rather than get lost within.

The city in the music video is Xining, the provincial capital of Qinghai province and the largest city on the Tibetan Plateau, with 2.4 million permanent residents. Han norms dominate Xining's language, architecture, and culture yet it is also home to more than 130,000 Tibetans. Payag and Gonpa are the two young men behind ANU. The band's full

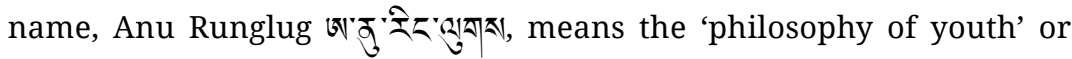
'youthism' in Tibetan. Originally from rural Nangqên/Nangqian County

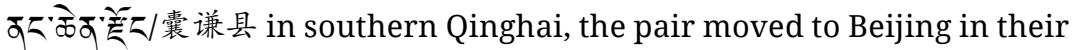
twenties to pursue their music dreams. Multilingual and media savvy, they make effective use of Chinese-language social media outlets such as WeChat and the video-sharing app Meipai to promote their music and fashion label (also called ANU), using one to cross-promote the other. ${ }^{17}$

Differing from the didactic cautionary tale of 'City', 'Fly' is more of a neo-liberal hymn to aspiration and self-realisation. The lyrics encourage listeners to 'fly' - breaking the chains of fate to love liberty, find their true soul, achieve their highest dream, and escape a meaningless life. And if you don't fly? ANU tell us that your hopes will be wasted and your life will be over.

Throughout the clip, the fast-moving imagery shifts back and forth between the urban and the rural. Rather than presenting a binary contrast between the two, both environments are represented as spaces for unfettered bodily motion and human achievement; people run, leap, 


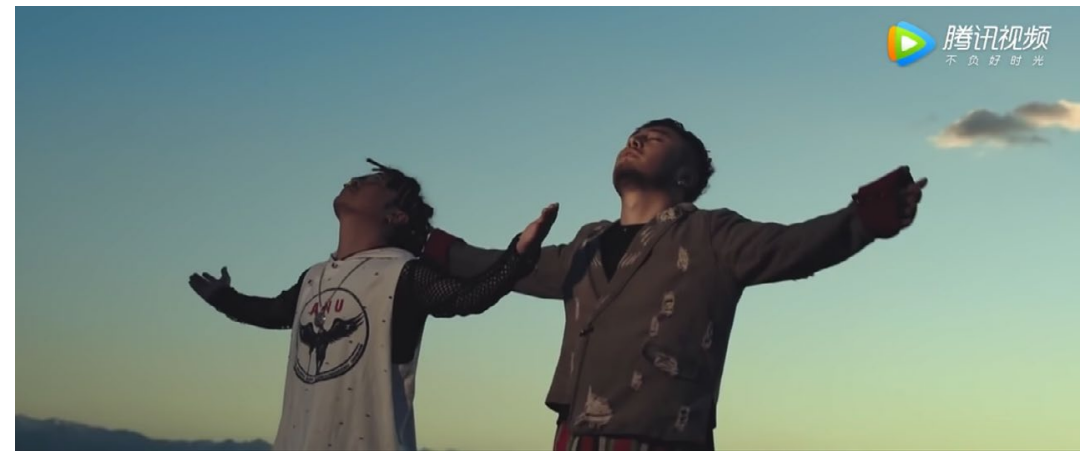

Still from the music video, 'Fly', by ANU

Source: Tibetube, YouTube

and dance; they raise their fists in the air as they crest a mountain, the city lights glowing below them. Importantly, we see a city that is at once unashamedly modern and exciting and also Tibetan. Stupas and prayer flags perch above the metropolis, where Tibetans have tattoos featuring traditional iconography such as the Buddhist 'endless knot' and breakdance to Tibetan hip hop in nightclubs.

'Fly' highlights another contrast. Many Chinese cities such as Chengdu and Xining, and even Beijing and Shanghai, are important cultural and social hubs for Tibetan youth. With the exception of Tibet University in Lhasa, all the major institutions of higher education for Tibetans and other 'ethnic minorities' (or minzu 民族 in Chinese for short), which are major engines of socioeconomic mobility, are located in such cities. For Tibetans, the most significant institutions are Qinghai Minzu University in Xining, Northwest Minzu University in Lanzhou, Southwest Minzu University in Chengdu, and Minzu University of China in Beijing. For those such as Payag and Gonpa who seek commercial success and fame, moving to one of these larger cities - often to establish a business enterprise with the help of government subsidies - is an important strategy. Provincial and local governments offer start-up grants to entrepreneurs to support establishment costs (such as rent and decorating a store or restaurant) and staff training. 
Yet Tibetans also migrate to cities in search of more menial jobs such as construction or factory work. The city has, therefore, in one way or another, become a place where Tibetans can pursue their dreams of upward mobility, regardless of their levels of skill and education. The Party-state uses the hukou 户口 (household registration) system and other forms of social control to guide Tibetan mobility and urbanisation. There is a hierarchical aspect to this. Rural migrants are more generally encouraged to move to, but not settle in, large cities, in a manner that sociologist Eli Friedman labels 'just-in-time urbanisation', attracting 'high-quality' 高素质 individuals to large cities as permanent residents while drawing on 'low-quality' 低素质 migrant labour as needed. ${ }^{18}$ In fact, for most Tibetans, urbanisation occurs in situ through the creation of small urban settlements built on former pastureland with only a couple of thousand inhabitants. In 1978, Qinghai province had just one city and six towns; today, there are six cities and 143 towns. ${ }^{19}$

\section{The Illusory City}

If 'Fly' subverts the moral binary proposed in 'City', 'Flame's Lament'

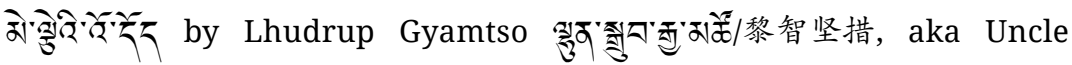
Buddhist, presents a more complex picture. It portrays both the city and the rural homeland as dreams - dreams in the sense of fantasies or mirages rather than aspirational goals. Uncle Buddhist delivers his lyrics in a rapid-fire whisper, both urgent and intimate. The acoustic guitar, soaring flute, and plaintive vocal hook of the chorus give the song a brooding, melancholic feel. And, while the video clips for 'Fly' and 'City' depict anonymous cities of steel, concrete, and glass, 'Flame's Lament' takes us to Lhasa, bringing the tensions of urbanisation to the very heart of Tibetanness.

The thirty-year-old Uncle Buddhist, now known as 'Scar K!d' in English, was born in a pastoral area along the upper reaches of the 
Yangtze River but grew up in the urban townships of Golog Tibetan

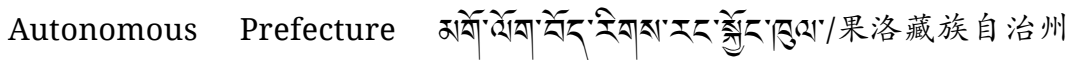
in south-eastern Qinghai. Like ANU, he honed his musical talents in Beijing, where he has lived since graduating in 2012 from the Beijing Contemporary Music Academy. His eclectic sound merges traditional Tibetan music with edgy urban rap in the style of Kanye West and Jay-Z, while singing in Mandarin, Tibetan, and English. ${ }^{20}$

The lyrics of 'Flame's Lament' begin by describing an idyllic image of the singer's rural childhood home: the shining sun, clear water, and the grassland where he would happily sleep. He then compares this with his life in the city, which is noisy, polluted, hot, bustling, and alienating. The city is a space of absence, loss, and exclusion, where you have 'no house, no car, no job', and even 'completely forget your mother tongue'

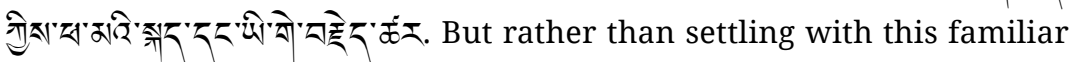
contrast between the idyllic rural and the nightmarish urban, the lyrics then take us back to the singer's hometown, which is now developed and polluted. As the lyrical pace and intensity build to a crescendo, we hear that the city is becoming green, and its air pure - the rural and

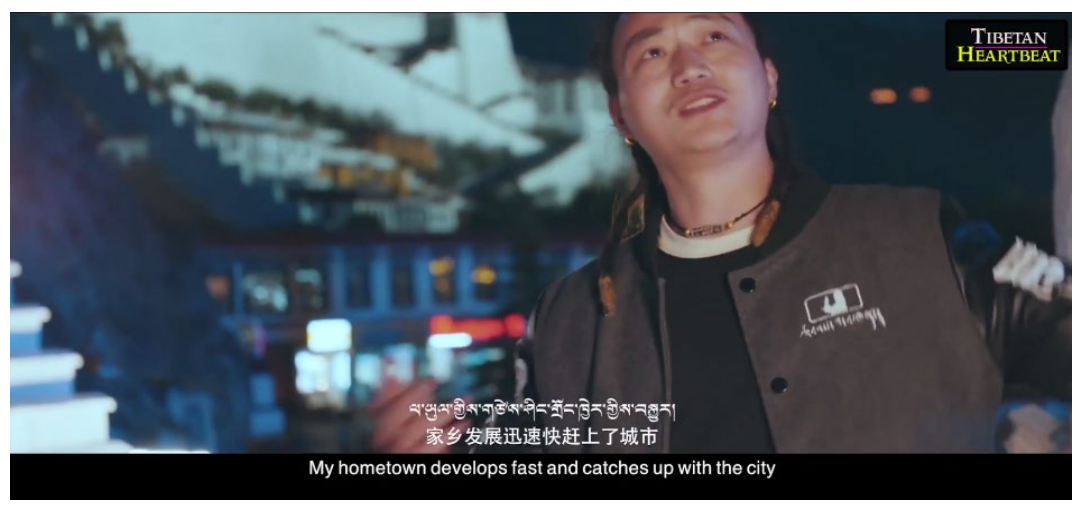

Still from the 'Dreaming of Tibet' music video by Uncle Buddhist \& Kalnor Source: Tibetan HeartBeat, YouTube 
urban have changed place - and the singer describes searching in vain for a road back to a homeland that has seemingly vanished forever.

Consistent with the complexity of the lyrics' treatment of the ruralurban divide, the images in the video clip also present contrasts that are less stark than those in 'Fly' or 'City'. Although we see iconic depictions of mountains and grasslands, most of the visuals are harder to parse. For example, the city is mostly represented by the Potala Palace, surrounded by bright lights and streaming traffic, and the rural is represented more often by images of small-town Tibet than by uninhabited nature. Like the lyrics, the visuals make it difficult to draw a sharp distinction between urban and rural, and to contain particular moralities and identities within either space.

Finally, 'Flame's Lament' draws attention to the translocalism and fractured identities of most Tibetans today. Although their rural homelands have been economically and socially dismantled, few Tibetans are able or have the permission required to move to large cities permanently thanks to the Party's 'just-in-time' urbanisation strategy. For most Tibetans, urbanisation presents two stark options. One is to relocate to low-tier towns - the orderly yet soulless prefecture and county-level settlements scattered across the Tibetan Plateau. The other is translocality - moving back and forth between urban places of employment and rural places of belonging; between exclusion from a dynamic urban socioeconomic context and inclusion in stagnant rural economies; between the social, linguistic, and cultural alienation of the city and the cultural security of the countryside.

\section{Urban Futures: Dream or Fantasy?}

President Xi recently asserted: 'Today, we must closely rely on the collective strength of each ethnic group if we are to achieve the China Dream. ${ }^{21}$ Xi's vision involves an urban and collective future for all 
Chinese citizens, including Tibetans. Cities are what Party officials call 'large melting pots' 大熔炉 in which to forge a shared national culture and identity and inscribe the thoughts, behaviour, and norms of the Han-dominated Party-state. By urbanising Tibet, the Party-state hopes to integrate Tibetans more firmly into the social fabric of the nation.

Yet, like other governments across the globe, the CCP also fears the instability associated with large-scale urbanisation and has sought to carefully manage it. ${ }^{22}$ It employs a toolkit of governance mechanisms such as the hukou restrictions, identification checks, facial recognition tracking, and other surveillance tools to regulate and monitor the flow of human and material capital to raise the 'quality' of urban populations and create a hierarchy of urban spaces. On the one hand, the Party stresses the need to make cities more accessible to ethnic minorities. On the other, it remains nervous about the clash of cultures and any spontaneous outbursts of resistance, especially in large urban centres. ${ }^{23}$ And so most Tibetan urbanisation occurs chiefly in small and mediumsized townships created by the rezoning and development of former pasturelands, rather than through large-scale migration into major Han metropolitan centres.

Tibetan pop songs highlight some of the complex responses of younger Tibetans in the PRC to urbanisation. For some, the city is the secret to realising their dreams; it is a place where they can move easily, express themselves, and achieve their full potential. For others, the city represents a nightmarish end to Tibetan ethnic and cultural identity. Many more Tibetans are trapped in a sort of peri-urban limbo, lamenting the rural past while aspiring to a brighter future under the city lights. As cities come to Tibet and Tibetans go to the city, urbanisation is presenting a new test of what it means to be Tibetan in today's China. 


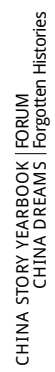


论坛 

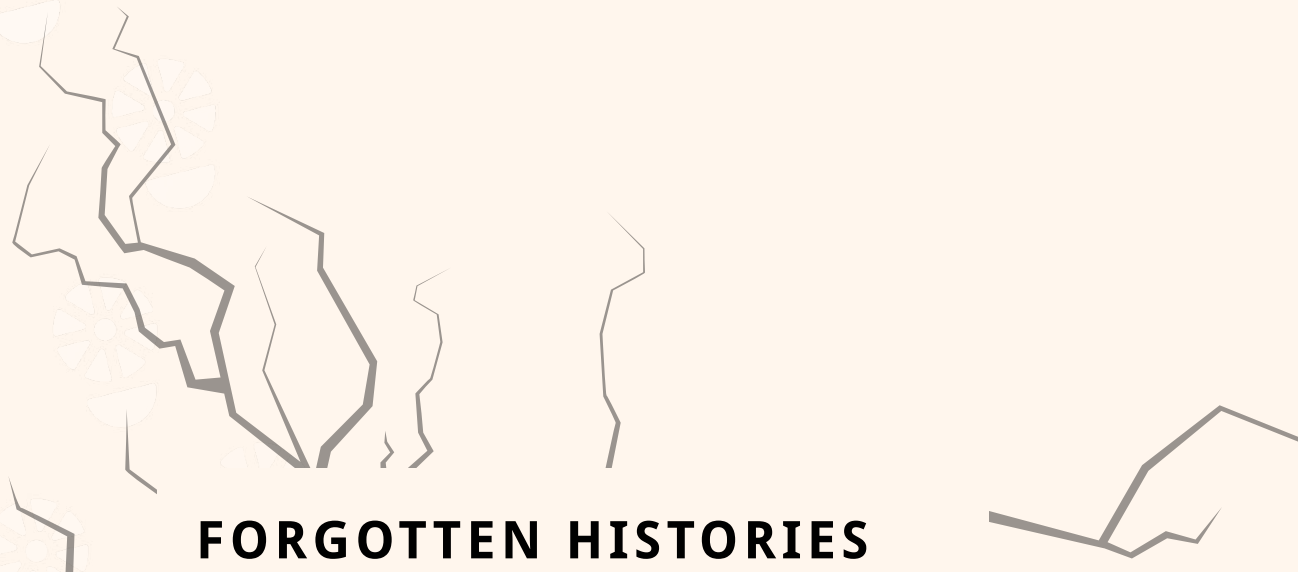

'Prairie Mothers' and Shanghai Orphans - uCHRALT OTEDE
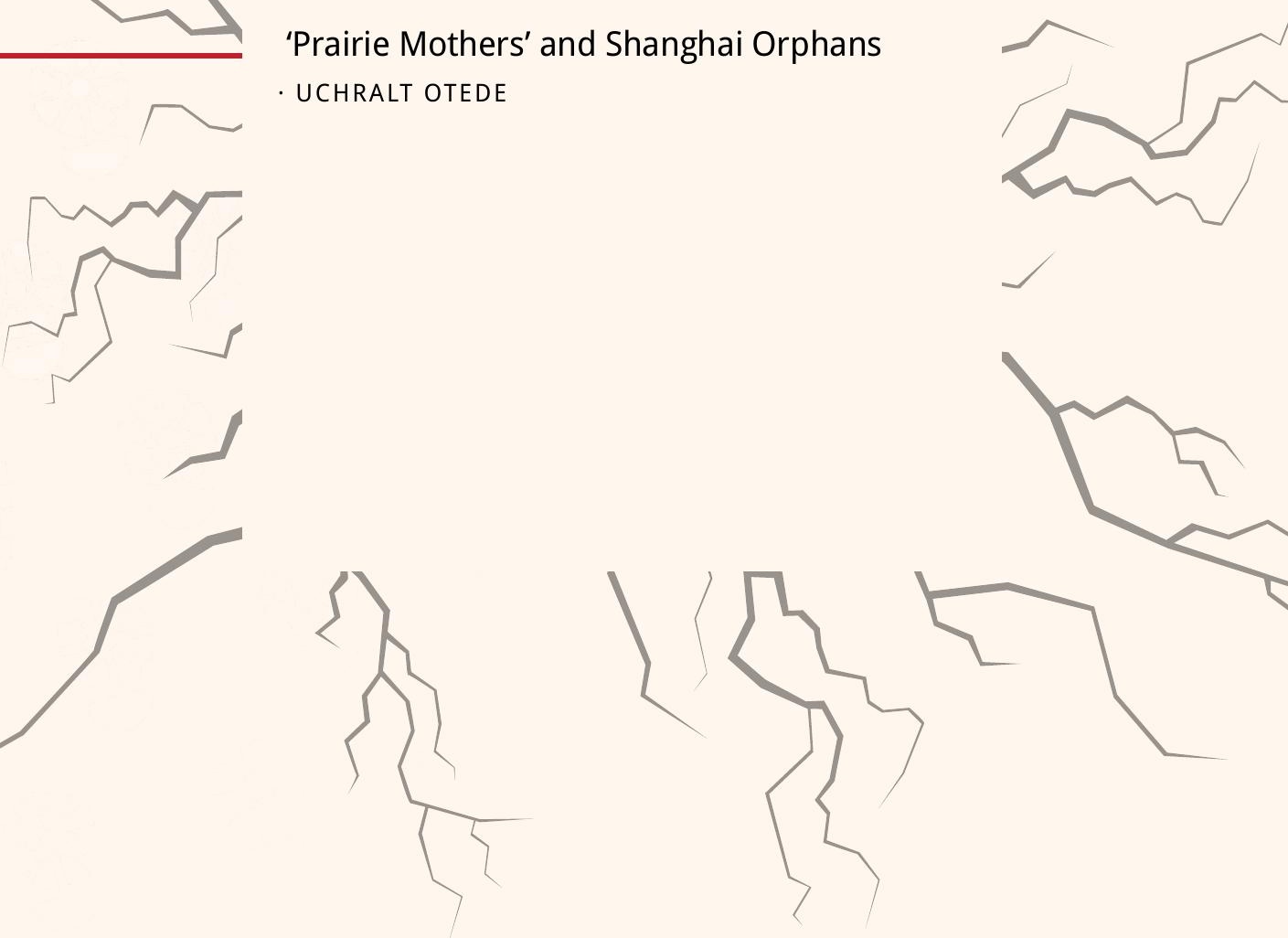


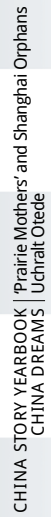




\section{'PRAIRIE MOTHERS' AND
SHANGHAI ORPHANS
Uchralt Otede}

O

N 17 SEPTEMBER 2019, President

Xi Jinping signed a presidential decree to award National Medals 国家勋章 and National Honors 国家 荣誉称号 to forty-two people on the occasion of the seventieth anniversary of the founding of the People's Republic of China (PRC). Among them was an ethnic Mongol woman, Duguima 都贵 玛, from Inner Mongolia, who won the honorary title of People's Model 人民 楷模. According to Xinhua, this medal

symbolises the major contributions made by the winners in various fields and industries and the exemplary role they play in inspiring the people of all nationalities in China to remain true to our original aspiration and keep our mission firmly in mind,

and to struggle ceaselessly to realise the Chinese dream of the great rejuvenation of the Chinese nation '1

At the awards ceremony, held in the Great Hall of the People in Beijing on 29 September, $\mathrm{Xi}$ personally awarded Duguima her honorary title and medal.

Duguima was born in 1942 to a herder's family in a rural community in Dorbod Banner 四子王旗 in Inner Mongolia. When she was nineteen years old, her fate became intertwined with a group of Shanghai orphans. From the late 1950s to the early 1960s, China experienced a catastrophic famine, which resulted in the deaths of tens of millions of people. Parents in the provinces surrounding Shanghai 
who were unable to feed their

counties in Inner Mongolia between children brought them into the city and abandoned them - with the total numbering in the tens of thousands. With Shanghai's food supply already under enormous pressure, Kang Keqing 康克清, then chairman of the National Committee for the Defence of Children, appealed to prime minister Zhou Enlai 周恩来 for help. Zhou discussed the issue with Ulanhu 乌兰夫, chairman of the Inner Mongolia Autonomous Region, who agreed to move 3,000 orphans to Inner Mongolia. These children, ranging in age from a few months to seven years, were sent in waves to several banners ${ }^{2}$ and

1960 and 1961. The local government of Dorbod banner assigned Duguima to its nursery school to look after twenty-five orphans before they could be adopted by local families.

For many years, the Party-state has promoted the story of how Inner Mongolians cared for the Shanghai orphans as a model of love, national unity, and patriotism. At the time of the fiftieth anniversary of the founding of the Inner Mongolia Autonomous Region in 1997, Ma Li 马利, then a journalist and deputy director of the domestic political department of the

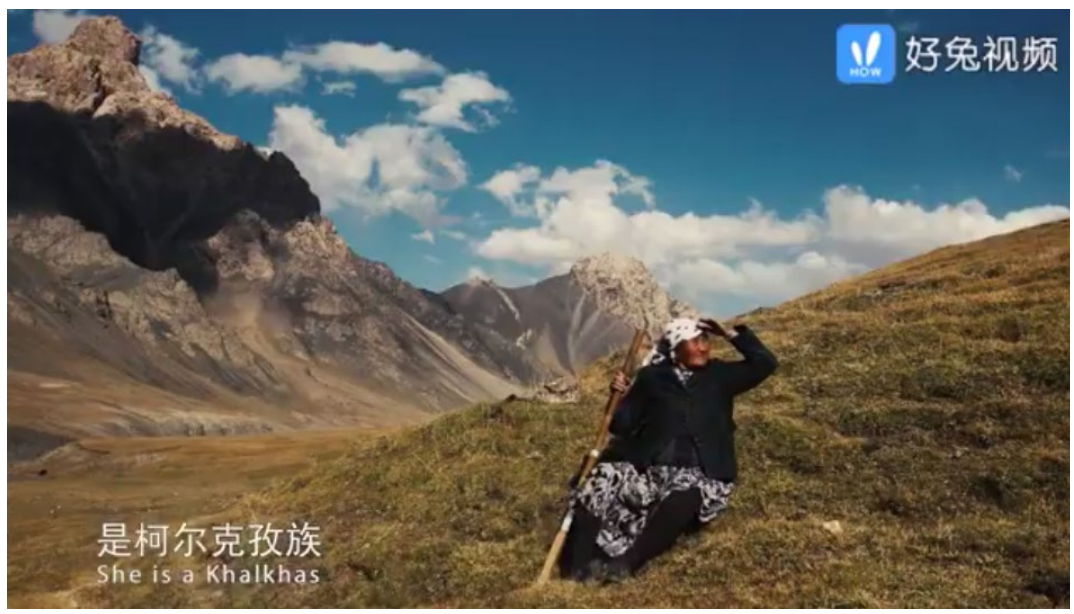




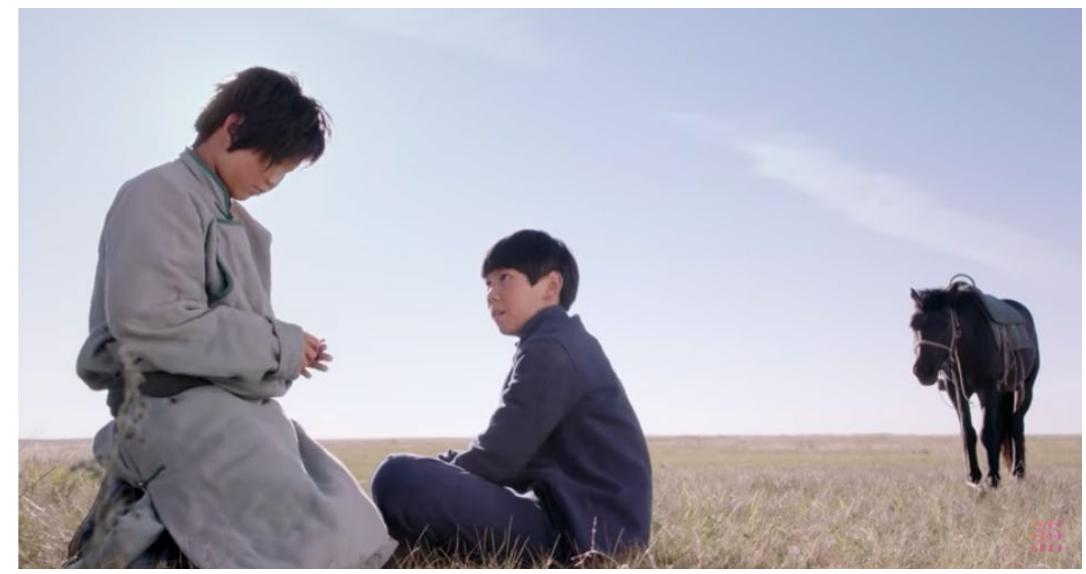

| Still from National Children

Source: 捷成华视一偶像剧场, Idol \& Romance, YouTube

People's Daily, wrote a widely read piece titled 'Three thousand orphans and prairie mothers' 三千孤儿和草原 母亲. Zhang Jinxi 张锦贻, director of the Literary and Art Theory Research Office of the Institute of Literature of the Inner Mongolia Academy of Social Sciences, commended Ma Li:

This is reportage of national and historical significance. It lets the people of all ethnic groups ... know the meaning of the big family of the motherland' 祖国大家庭 and the 'national unity’ 民族团结。

Inspired by Ma Li's work, the famous Mongolian director Ning Cai 宁才 filmed a sixteen-episode TV series, The Silent Emin River 静静的艾敏河, about the 'prairie mothers' and the Shanghai orphans. The national channel CCTV 1 broadcast the series in 2002. In 2009, Ning Cai filmed the related film, My Mongolian Mother 额吉, which was selected as a key 'tribute' film 国庆 献礼片 for the sixtieth anniversary of the founding of the PRC. In 2019, for the seventieth anniversary, the State Administration of Radio, Film and Television selected the 2018, forty-episode TV series on the same subject, National Children 国家孩子, by director Baatar 巴特尔 (whose mother is Mongolian and father is Han Chinese).

For all the prominence given to the story of the orphans and their 'prairie mothers', many questions remain. The 


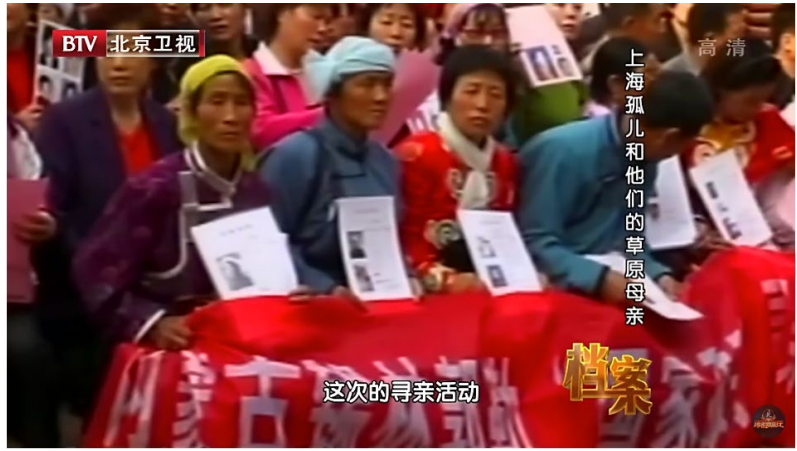

Party-state maintains that the extreme shortage of food in China from 1959 to 1962 was caused by natural disasters. In contrast, independent scholars in China and overseas highlight the role of Mao's Great Leap Forward, which, combined with the withdrawal of Soviet aid and natural disasters, led to economic chaos and industrial and agricultural collapse. Other questions persist about the famine's total death toll; estimates range from four million to thirty million. The total number of Shanghai orphans is another mystery. According to a reporter for the Southern People Weekly 南方人物周刊, $\mathrm{Wu}$ Congling 吴聪灵, there were at least 50,000 orphans. Children were sent not only to Inner Mongolia, but also to Shandong, Shanxi, Henan, Hebei, Shaanxi, Jilin, Xinjiang, and other places. ${ }^{4}$
According to a 2015 CCTV news report, less than one percent had the opportunity to reunite with their biological families in later life. ${ }^{5}$ Most step-parents have been unwilling to tell the truth to the orphans, while many orphans have not actively looked for their own biological parents because of not wanting to hurt their step-parents. In many cases, orphans started the search for their biological parents after the death of their step-parents, although, because they lack detailed birth records, this has proven very difficult. Some have used newspapers and online platforms, and some have visited Shanghai, Zhejiang, and Jiangsu to find their relatives. While a small number of orphans had bodily markings, such as tattoos and ear-cuts, left by their biological parents, most 
have had to rely on observations of facial similarity to make preliminary matches, followed by DNA testing to determine relationships. In recent years, the average age of orphans has reached sixty, and most of their biological parents are no longer alive, leaving them only with the hope of meeting their brothers and sisters. dream to this day.
Duguima may have been a People's Model in her 'ceaseless struggle' to support these orphans in times when rejuvenation of the Chinese nation was just a very remote dream. For many of the orphans themselves, reuniting with their birth families remains a distant 


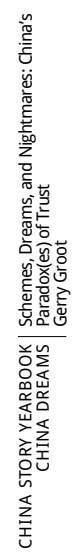




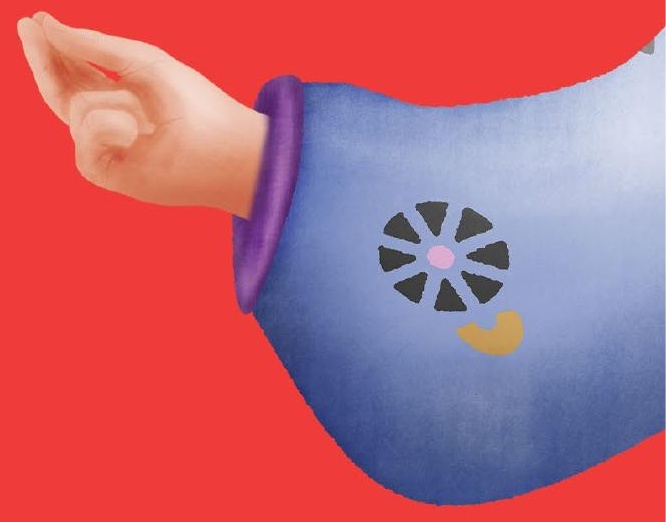




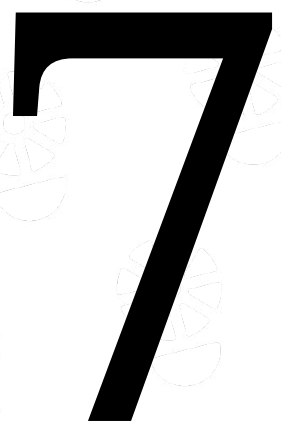




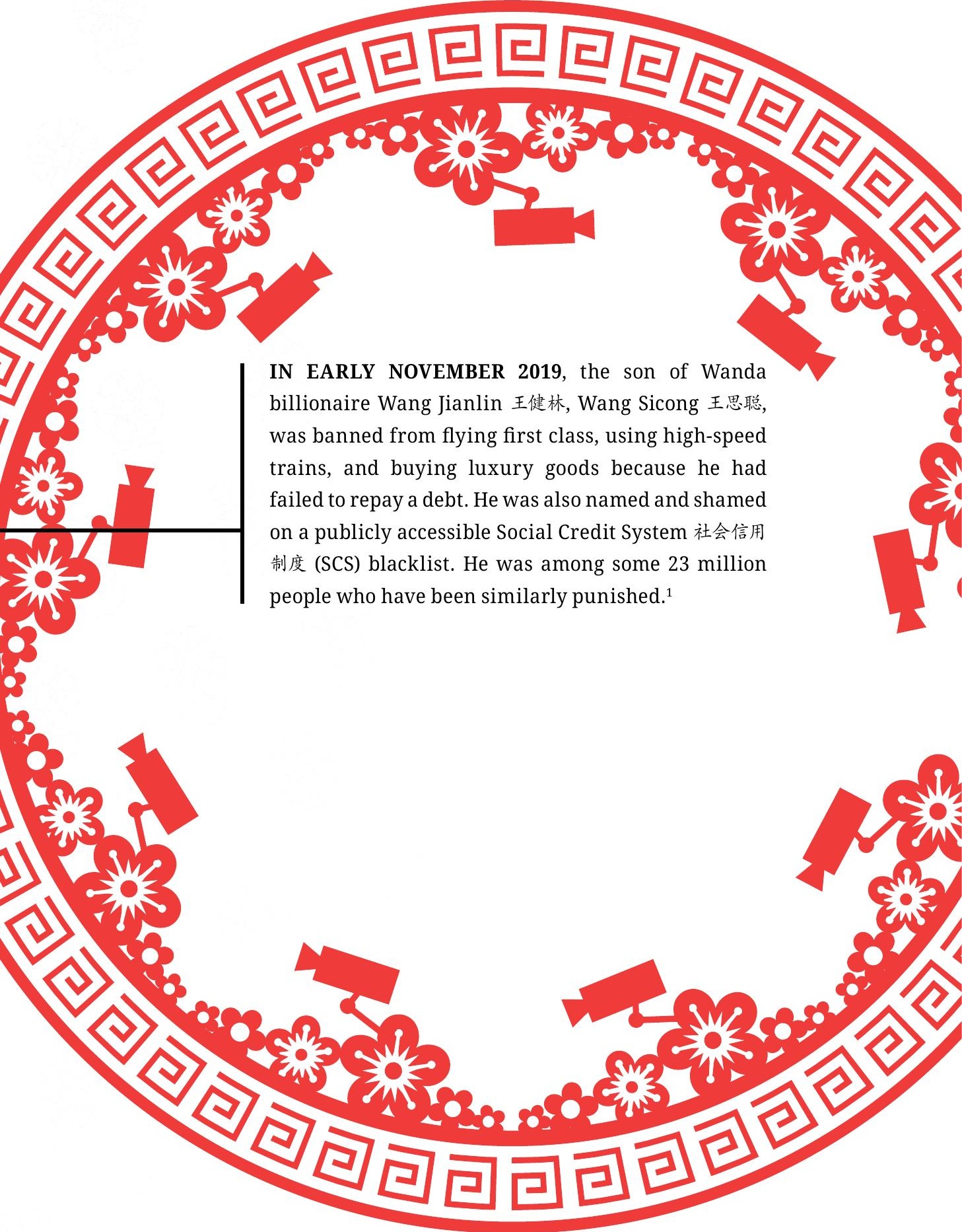


In some places, debtors' faces are flashed on to public television screens when they are in the vicinity or those around them receive phone notifications that a debtor is near. A song, 'Be as Good As Your Word' 说到做到, is just one way the Party-state conveys the Santa-like message: we know if you've been good or bad, so be good for goodness sake. ${ }^{2}$ The latest phase in the evolution of these initiatives, embodied in the 2014-2020 Social Credit System plan 国务院关于印发社会信用体系建设 规划纲要(2014-2020年)的通知, ${ }^{3}$ ends soon, but there is no end in sight to the SCS - just one aspect of what many in the West are calling the People's Republic of China's (PRC) 'surveillance state'. ${ }^{4}$ Closed-circuit television (CCTV) cameras are another. Chongqing is now reputed to be 'the world's most surveilled city', with some 2.58 million cameras for a population of fifteen million people. ${ }^{5}$ On 1 December 2019, it became mandatory for all applicants for new phone SIM cards across the country to have their faces scanned - supposedly to prevent identity theft, but it also facilitates the use of facial recognition software systems. ${ }^{6}$

In some places, bio-data collection augments video surveillance. An in-depth New York Times article about Chinese researchers working on facial imaging based on DNA samples - particularly among the Uyghur Muslim minority of Xinjiang - indicates how bio-data can be integrated into larger systems of surveillance and control. ${ }^{7}$ Both Uyghurs and Tibetans are heavily surveilled, policed, and documented right down to recording of their iris patterns, blood types, fingerprinting, and facial scans (see the China Story Yearbook: Power, Chapter 4 'Internment and Indoctrination: Xi’s “New Era” in Xinjiang', pp.98-111). The Party-state's emphasis on developing artificial intelligence (AI) also feeds into the strengthening of these systems of surveillance and control (see Chapter 5 'AI Dreams and Authoritarian Nightmares', pp.143-154). The new cybersecurity program released on 1 December and based on the 2016 Cybersecurity Law further strengthens surveillance, censorship, and the control of data in the online sphere. As Steve Dickinson wrote in the China Law Blog: 'The core of the plan is for China's Ministry of Security to fully 
access the massive amounts of raw data transmitted across Chinese networks and housed on servers in China.' ${ }^{8}$ Or, as Guo Qiquan 郭启全, chief engineer in the Cybersecurity Bureau, famously put it: the goal is 'full coverage'. Overseeing it all is the bureau's new director, Wang Yingwei 王菜玮, who has a $\mathrm{PhD}$ in applied mathematics from Peking University and personal experience developing pattern recognition systems for policing purposes. ${ }^{9}$

Ideology meets technology and surveillance in the app Study Strong China 学习

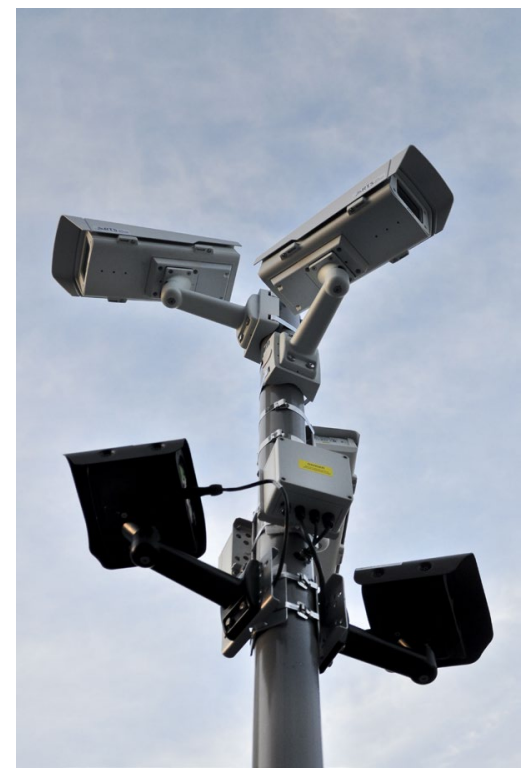
强国, the name of which is also a cognate for 'Study Xi and strengthen the country'. The Party monitors the progress and activity levels of the 100 million-plus users of the app, which is mandatory for party members. ${ }^{10}$

\section{What to Make of All This?}

The Netflix drama Black Mirror and dystopian analogies conjured up by Western observers potentially misunderstand the nature of China's surveillance state. The present reality, while dark enough, is more complex and fragmented than such totalitarian narratives allow. The use of facial recognition and AI to name and shame jaywalking pedestrians by showing their faces on public screens in the high-tech southern city of Shenzhen, for example, is still only a local initiative. That the AI company involved 
wants to link the results to social media accounts such as WeChat, ${ }^{11}$ however, is likely a sign of things to come - as are the fast-evolving technologies surrounding and linking bio-data collection and surveillance.

To understand the logic, limitations, and future trajectories of these systems, we should examine the origin and nature of the social credit schemes. One key lies in much older ideas of public shaming, which are evident in the Shenzhen example above, and another in the ancient philosophy of 'legalism': governance by reward and punishment (see Chapter 2 Forum 'Legalism and the Social Credit System', pp.73-77). For these to work as intended, there needs to be a perception of fairness. Anything less than universal implementation of social credit schemes is likely to compound the general lack of public trust in the Party-state at the lower levels, with which the public has the most frequent and direct contact, and if that becomes evident, it can only result in more surveillance and further declines in mutual trust.

\section{China's 'Paradox (es) of Trust"12}

In October, Xi Jinping called for more utilisation of blockchain technology across society to help build a 'trusted system' ${ }^{13}$ Trust 信用 and honesty (sometimes translated as sincerity) 诚信 are social goods that are often in short supply in China. The two are related; as psychologist Nigel Holt has written, 'honesty is a marker that encourages trust and cooperation'. ${ }^{14}$ Holt was writing in response to a controversial study conducted in 355 cities across forty countries and published in June 2019 in Science. China ranked last in terms of whether people who 'found' a wallet containing the contact information of the 'owner' returned it. Zhou Xinyue 周欣 悦 of Zhejiang University was one of many who questioned the survey's methodology, noting that in a separate Chinese study, seventy-one percent of test wallets were neither kept nor returned, but simply left untouched. She notes that behaviour is shaped by 'economic and psychological costs and the culture-specific norm' and that 'active helping and honesty are 
distinct concepts'. ${ }^{15}$ News reports of the survey stirred both anger and selfsearching online, some of which can be found in forums such as Zhihu 知乎, which features a category titled 'The honesty crisis 诚信危机'.

The background to this is historical, philosophical, and political. In addition to legalism, China had a strong Confucian tradition that emphasised loyalty within family and clans as well as to the ruler, and a tradition of collective punishment that encouraged self-policing within clans and neighbourhoods. But there was little incentive and no responsibility to look after anyone outside the family, clan, and emperor and a consequent awareness that strangers similarly had no responsibility to you but were always potentially dangerous — or even ghosts.

After seizing power in 1949, the Chinese Communist Party (CCP) began staging a series of mass political movements that assumed a set percentage of people were 'bad elements' ('rightists', 'counterrevolutionaries', and so on). These movements demanded the participation of ordinary citizens in identifying such people among their peers and colleagues. During the Cultural Revolution (1966-1976), the Party even encouraged children to denounce their parents and teachers. These factors, combined with dramatic reversals of policies and corruption, have all contributed to a trust deficit.

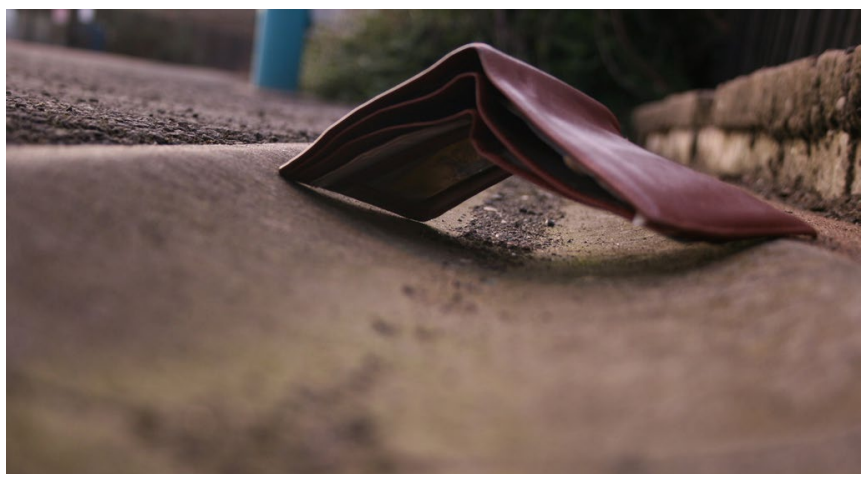




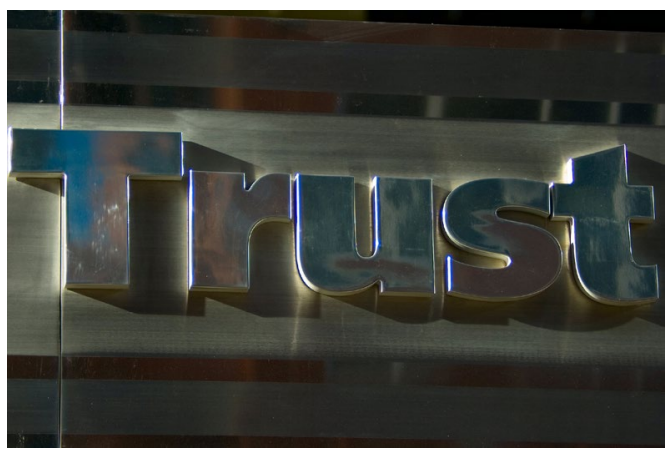

For example, personal relations or guanxi 关系 make it possible to navigate bureaucracy and business. Guanxi is often consolidated by giftgiving (including bribery) and other behaviours, ranging from excessive banqueting to visiting hostess clubs. This builds mutual trust based on the potential for mutual incrimination. ${ }^{15}$ Yet such behaviour is itself corrosive of broader social trust because it readily allows people to assume that power and privilege are transactional and not merit based. In addition, at the lower levels, the lack of transparency and procedural fairness as well as exposure to corruption by Party and state officials are generally seen as resulting from the moral failings 失道 or lack of 'quality' 素质 of the officials involved, as opposed to systemic failings of the Party-state system. The National Public Complaints and Proposals Administration 国家信 访局 provides a space for venting about problems, yet only a tiny number are ever resolved. ${ }^{17}$ When they are resolved, the blame lands on 'immoral' officials and not on structural issues, such as how guanxi networks and political imperatives are embedded in administrative systems from top to bottom. As a result, trust in the central levels of the Party and government remains high. ${ }^{18}$ The Party-state nonetheless recognises that the issue of trust poses a serious challenge to its legitimacy. So, on the one hand, it pursues highly publicised anticorruption campaigns and, on the other, it builds social credit schemes. 


\section{China's Developing Social Credit System(s)}

Currently there are some forty rapidly evolving experiments in social credit. China cyber-policy specialist Séverine Arsène likens social credit to a 'chimera' to emphasise its

patchwork, decentralized and bureaucratic character. Thus far the system is an assemblage of heterogeneous indicators and enforcement mechanisms which differ according to the geographical location individuals find themselves in, and the kind of professional activities they are involved in. ${ }^{19}$

Some systems focus on financial probity. In the twenty-first century, after decades of market reforms and the rise of commercial enterprises in China, banks and other financial institutions need to assess the creditworthiness not only of companies, but also of individuals who may want to take out mortgages or personal loans. With people now freer to move around the country, such data have to be available nationally. Credit China 信用 中国, which takes guidance from the People's Bank of China (РBOC), keeps a national public database of blacklisted enterprises and individuals. ${ }^{20}$

As Jeremy Daum of chinalawtranslate.com points out, this system aims to regulate business and force compliance with the law. There are blacklists 黑名单 that lead to punishments, such as that experienced by Wang, and 'red lists' 红名单 that lead to rewards. The designers of locallevel systems, guided by central government directions and institutions such as the PBOC, are also adjusting them to protect whistle-blowers who alert authorities to malfeasance and public officials from undue attacks. ${ }^{21}$

These local government social credit systems focus on four key areas: governmental affairs, commercial activity, social behaviour, and encounters with the judicial system. As coordination between government levels, departments, and commercial bodies improves, the goal, according to the State Council, is to 
use credit information exchanges and sharing to bring about linked credit rewards and punishments across multiple departments and regions, making it so that the trustworthy benefit at every turn and the untrustworthy can't move an inch. ${ }^{22}$

For this reason, some observers have described these systems as 'gamifying' social compliance.

Xiamen's Bailu ('egret') score 白叠分 and Fuzhou's Moli ('jasmine') score 莱莉分 together cover eleven million registered local residents. Local Public Credit Platforms 公共信用信息分享平台 assign scores based on personal data, contributions to the public good (honours, acts benefiting public welfare), financial behaviours (overdue loans, donations to charity, and so on), and legal violations (civil, administrative, and criminal). ${ }^{23}$ While most of the negative criteria are objectively measurable, the basis for positive, or red credit is more open to interpretation. Crucially, these schemes are largely voluntary; in 2019, they involved only twenty-one percent of Fuzhou residents and a mere five percent of Xiamen residents. Few low scorers have been penalised; there is at present no legal basis for that. There is neither much public awareness nor much interest in the schemes. ${ }^{24}$

The other layer of complexity in these systems is the role of commercial credit operators, including online payment and credit services and peerto-peer lending, which has resulted in the wide dispersal of financial data. In 2015, the PBOC allowed a number of companies to trial new credit rating systems; the most famous is Alibaba's Sesame Credit 芝麻 信用, which rates users via a points system. ${ }^{25}$ But along with companies such as Ant Financial and Tencent Credit, they may also access government blacklists and factor them into their own rankings. It works both ways: some local governments subcontract data management to firms such as Sesame Credit. ${ }^{26}$

As Arsène notes, this has led to a 'wild proliferation of ratings' mixing public and commercial data. She gives the theoretical example of a young 
Shanghai resident who might have scores on Sesame, the municipal Honest Shanghai app, and even a third app, Unictown 优你通, ${ }^{27}$ which was developed in conjunction with the Communist Youth League Central Committee and the National Development and Reform Commission. The Unictown app is designed 'to give college students and fresh graduates a taste of the rewards brought by having a good social record' and values 'Confucian ethics' such as righteousness, benevolence, good manners, wisdom, and trust. ${ }^{28}$ Public information about Unictown offers little clarity about its methodologies. ${ }^{29}$ Unictown claims it is designed to reward good behaviour, yet shaming alleged wrongdoers is at least one of its functions.

\section{Surveillance, from Tiananmen to Xinjiang and Beyond}

Thirty years after the events of 4 June 1989, the photograph of 'Tank Man' remains an iconic image - at least outside China about standing up to power.

On the anniversary of these events, some foreign reporters approached passers-by in Beijing to

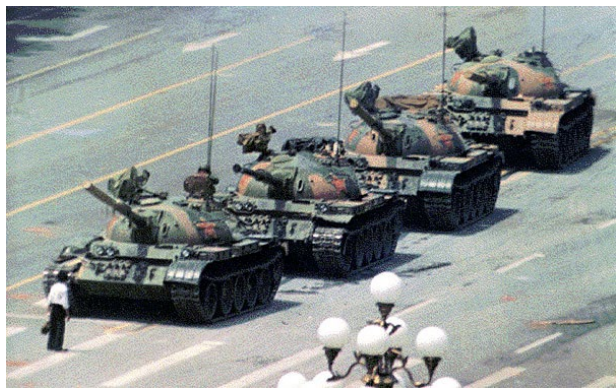

4 June 1989: 'Tank Man'

Source: Michael Mandiberg, Flickr ask them whether they recognised the image. Police hovered in the background filming the proceedings. ${ }^{30}$ Three decades of censorship had been effective: some thought the photo had been taken in another country.

Observing the changes from afar, a Dutch cartoonist drew the Tank Man, but now with his bags full of branded goods, including one from Huawei, transforming him into ‘Consumer Man'. Above Consumer Man's head looms a surveillance camera. In 2014, James Areddy described 


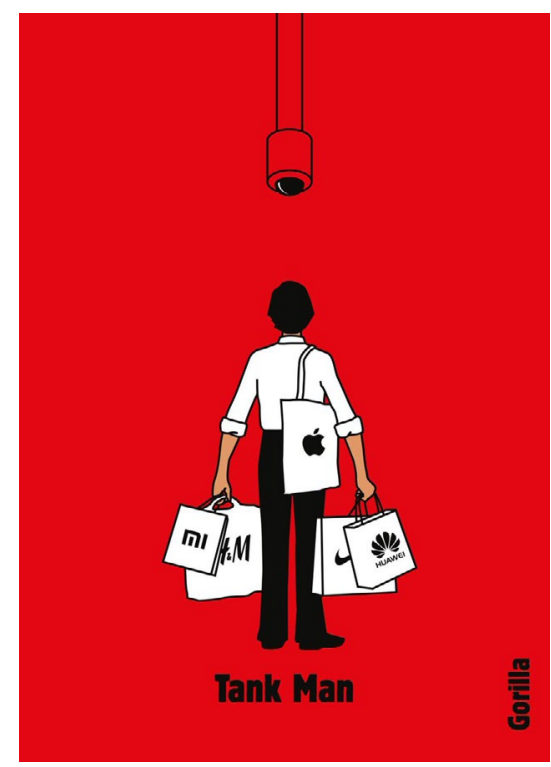

| 'Consumer Man'

Source: The Daily Gorilla, Twitter
China's then 100 million surveillance cameras as the legacy of 1989;31 they are expected to total some 300 million by 2020 .

In Xinjiang, cameras are a key element in the system of tracking, control, and intimidation that also uses AI and available databases, so that, for example, police can pull up personal information on a person passing through a checkpoint and know whether they have been to a mosque or, for that matter, a coffee shop that day. ${ }^{32}$ According to the tranches of leaked documents published by The New York Times and the International Consortium

of Investigative Journalists, an additional function of the use of AI is to help the police carry out 'predictive policing'. Since 2016, Xinjiang's Integrated Joint Operations Platform 体化联合作战平台 has been used to pick up 'suspicious actions' and generate lists of those 'who ought to be taken, should be taken' 应收尽收. ${ }^{33}$ SenseNets, ${ }^{34}$ a Shenzhen-based firm specialising in facial recognition and crowd analysis technology, is working with the Xinjiang government to perfect its surveillance systems.

The current reality across the PRC is of a very messy complex of surveillance systems driven by perceived security concerns, local government needs, higher-level government imperatives, and commercial interests. There is as yet no integrated national system of surveillance, but among the highly advanced surveillance systems being developed are specific technologies such as Yidiantong's 亿点通 Key Person Control database. These target criminals (including parolees, those in community 
corrections, and drug users); people seen as threats to social and political stability (petitioners, Uyghurs and other Muslims, rights lawyers, and so on); and others such as members of 'Evil Cults' (see Chapter 2 Forum ' "Evil Cults” and Holy Writ', pp.79-82), internal migrants, and the mentally ill. Yidiantong's software also covers those who are considered a threat to national security, extremists, foreigners, and 'online targets' - presumably, critics on social media. Another Yidiantong product, Community Alert 社区警务, maps communities down to the apartment level for the benefit of policing. ${ }^{35}$

Emile Dirks' examinations of tenders led him to conclude that technology suppliers were extending the scope of their databases in response to demands from local public security organs. ${ }^{36}$ It is the demand from below rather than orders from above driving much of the mission creep.

Non-Chinese in China are also subject to surveillance, including iris and fingerprint scans at immigration points. TikTok, created by the Chinese company ByteDance, is wildly popular among young people outside China, but when a young American Uyghur woman posted a clip that was ostensibly about makeup but quickly segued to the subject of human rights abuses in Xinjiang, it was deleted, raising concerns about censorship and the potential for such apps to also send user information back to China. ${ }^{37}$

The Carnegie Endowment for International Peace reports that at least seventy-five countries including liberal democracies now use Chinese technology from firms such as Huawei, Hikvision, Dahua, and ZTE, making China the world's largest supplier of surveillance technology. ${ }^{38}$ This does not take into account issues raised by Chinese mobile phone technology and apps such as TikTok. The American military is among those concerned by the potential for Chinese actors to remotely access Chinese-made surveillance cameras and systems. ${ }^{39}$ Foreign companies, conversely, have been implicated in human rights abuses through sales of surveillance technology to the PRC. 


\section{Demands for Better Privacy Protection in China}

While censorship ensures that most Chinese are unaware of the literature, movies, and television series that trigger Western fears of totalitarian dystopia, some are pushing back against creeping oversight. Although one survey revealed that sixty to seventy percent of Chinese felt safer because of surveillance, they also expressed concern about the vulnerability of databases and loss of personal information. Increasing numbers of Chinese are becoming sceptical after encountering facial recognition systems now present in places such as subways and even apartment blocks - that did not work, with negative consequences. ${ }^{40}$ In November 2019, one man took a private wildlife park to court for enforcing facial recognition for entry though he had accepted the use of fingerprint scanners in the past. ${ }^{41}$ Qinghua professor Lao Dongyan 劳东燕 wrote on WeChat that no attempts had been made to establish any legitimacy for facial recognition on the Beijing subway or even whether it would improve efficiency. Lao also noted that the increasing use of identity checks, even to enter or leave places such as her own university, was hardly a sign of increased trust. ${ }^{42}$

Protestors in Hong Kong - hyper-aware of the consequences of surveillance - have attacked 'smart lampposts' they suspected of being used to monitor them and smashed CCTV cameras in Mass Transit Railway stations and elsewhere. They have famously protected their identities with masks (an 'anti-mask' law was struck down by a Hong Kong court in November, infuriating Beijing), aimed lasers at CCTV cameras during demonstrations, and stuck reflective Mylar on goggles to defeat facial recognition systems.

While general acceptance of social credit and surveillance in mainland China seems to be high, this may change should it become apparent to broader sections of the population that the criminal, deranged, and religious are not its only targets. 


\section{Conclusion}

China's surveillance systems remain largely fragmented due to the PRC's administrative complexity and wide variations in the ways many different technologies are deployed. It is for reasons such as these that Arsène believes full integration is all but impossible. And yet the systems will continue to multiply. Dirks writes:

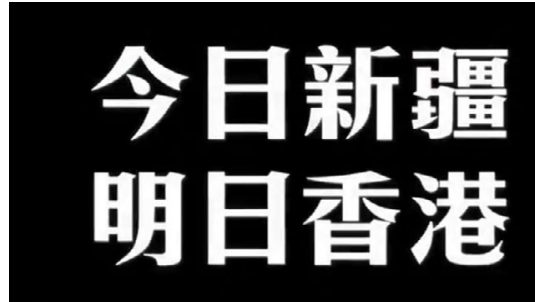

Xinjiang's present will become Hong Kong's future

Source: @rhokilpatrick, Twitter

It is unclear what key individuals these systems will target next. What is clear is that in the absence of robust media or judicial oversight or any other institutional checks on the Communist Party's domestic security apparatus - key individual management [systems by which individuals are targeted] will continue to metastasize, bringing ever greater swaths of the Chinese public under its control. ${ }^{43}$

The central Party-state under Xi Jinping seeks to increase social trust and hence trust in the government. Yet local experimentation and variations in social surveillance and control not only contribute to the system's incredible complexity. They are also likely to result in unintended consequences and perverse outcomes. Given the opaque interplay between governmental and commercial interests, sooner or later there will be actions that inspire significant public anger. While Han Chinese currently display little or no sympathy for the suffering of Uyghurs, if similarly extensive and intrusive biometric testing, surveillance, and data collection regimes are applied more generally, public attitudes could change. ${ }^{44}$

The greatest paradox is that if the Party displays no trust in its own citizens by employing ever-more intrusive social monitoring and surveillance, the likely result will be even more distrust, leading to unrest, leading to even more monitoring and control — for such are the lessons of escalation in Xinjiang. 
论坛 

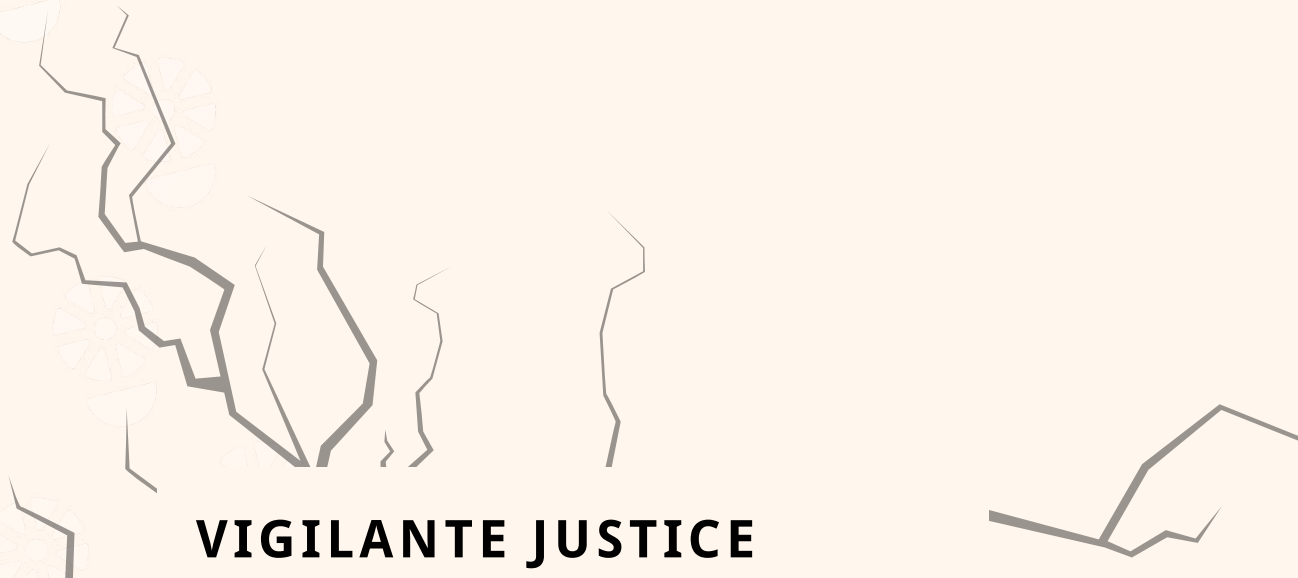

Taking Justice into their Own Hands: 'Netilantism' in Hong Kong - LenNON YAO-CHUNG CHANG
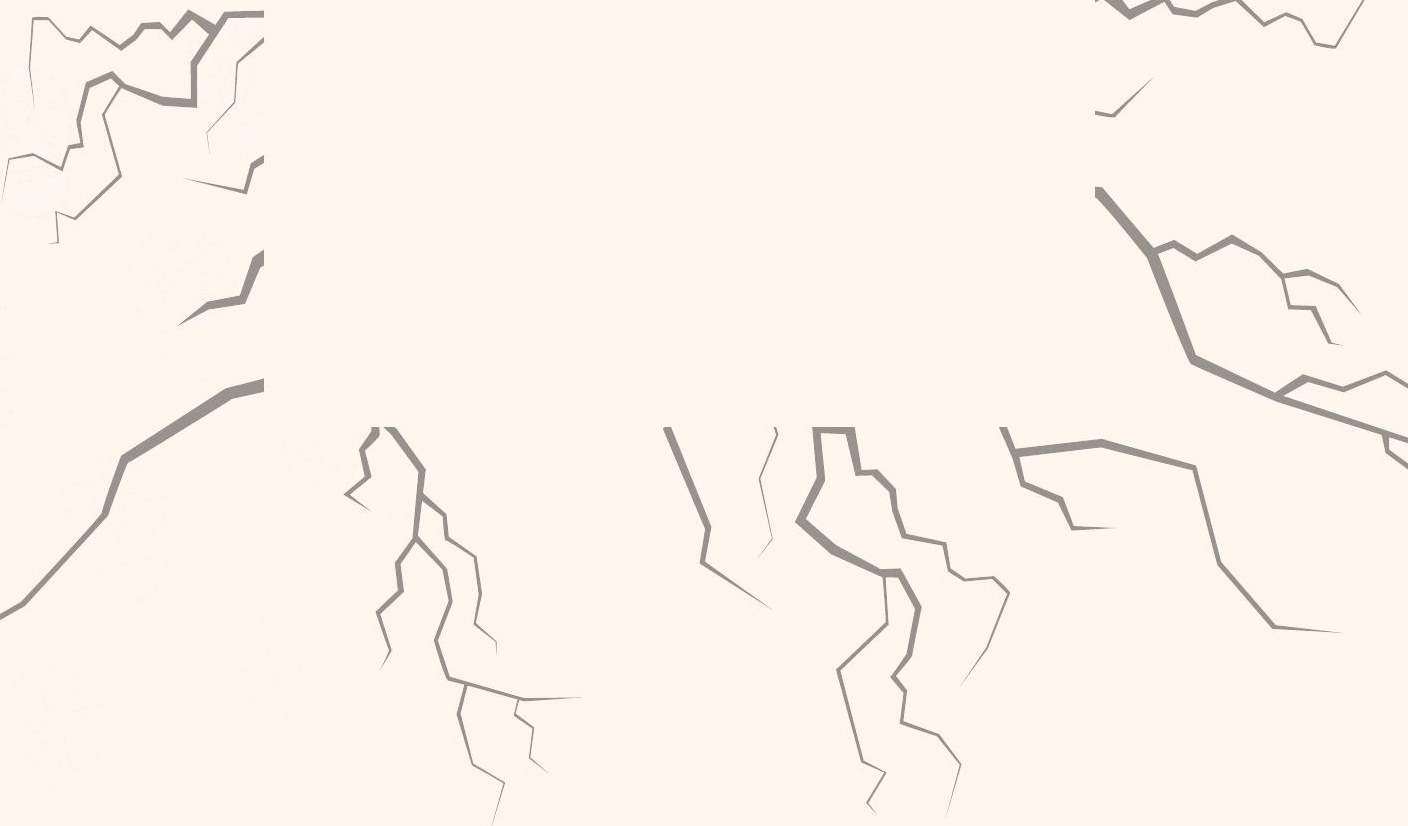


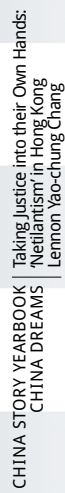




\section{TAKING JUSTICE INTO \\ THEIR OWN HANDS: \\ “NETILANTISM' IN \\ HONG KONG \\ Lennon Yao-chung Chang}

$\mathrm{T}$

HE 2019 HONG KONG protests (see Chapter 2 'Hong Kong's Reckoning', pp.51-67 and Chapter 8 'Hong Kong and the Tiananmen Playbook', pp.223-235) have been called protests with 'no main stage' 無大台. Most of the activities have been organised via brief messages distributed through digital technologies. While digital technologies such as WhatsApp and Telegram, as well as online forums such as HK Golden 高登, were also used in the 2014 Umbrella Movement, there was still a centralised core group who made decisions. However, the 2019 protests were famously 'leaderless'; decisions on actions and gatherings, and even the writing of the lyrics to the newly composed anthem, 'Glory to Hong Kong' 願榮光歸 香港, were made collectively using digital technology. Anyone could organise an event and disseminate news through apps or online forums. This made the 2019 movement more flexible and creative compared with its predecessor; it could 'be water'. It also made possible simultaneous protests in all of Hong Kong's eighteen regions and enabled different types of protests, including flash mobs at shopping malls singing ‘Glory to Hong Kong’ 願榮光歸香港. ${ }^{1}$ 


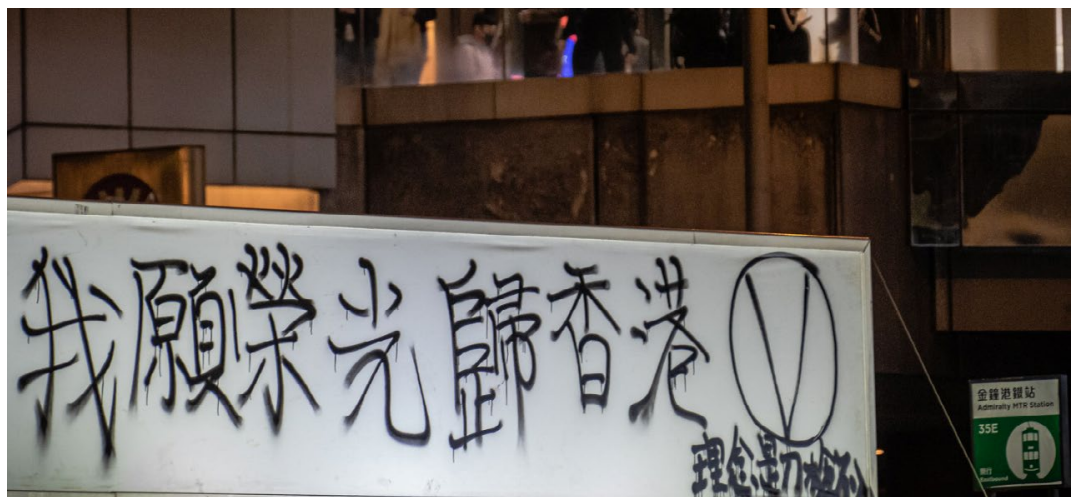

'Glory to Hong Kong' graffiti

Source: Studio Incendo, Flickr

Protesters and their sympathisers also used digital technologies to identify 'black police' 黑警 — police who had allegedly facilitated attacks on protesters by criminal triads or who used excessive force. They also used digital technologies to identify those who had been arrested, and to inform family and friends.

Internet vigilantism aimed at exposing the personal details of police and their supporters falls under a kind of doxing known in Chinese as 人肉搜索 or 人肉搜查 'human flesh searching' or 起底 'digging through to the bottom layers'. The term first appeared on the mainland in early 2000 and has become common in the greater China region (that is, the PRC, Hong Kong, and Taiwan). Since
2010, doxing has become a common phenomenon throughout the world. It is a type of collective online action aimed at shaming and punishing criminals or deviants in order to reinstate legal or moral justice.

In our 2016 paper on the subject, Ryan Poon and I used the term 'internet vigilantism' (or 'netilantism') to refer to online attempts to identify crime (for example, through anticorruption activities in China), to investigate crime or deviant behaviour (for example, cases of police brutality in Hong Kong), and/or to punish criminals (for example, cyberbullies and online child predators) through public naming and shaming. ${ }^{2}$ We looked into Hong Kong students who participated in netilantism and found 
that they tended to have higher selfconfidence than others and believed they could contribute to change in the world. They also believed that the Hong Kong criminal justice system was not effective in delivering justice, and therefore took matters into their own hands through netilantism.

For example, in the 2019 hunts for 'black police' acccused of using excessive force on protestors, internet netilantes typically disclosed not only the names and identification numbers of the police, but also personal information about their family members. The Hong Kong Supreme Court has issued an interim injunction against the 'unlawful and wilful' disclosure of personal information about individual police. ${ }^{3}$ Previously, the Junior Police Officers' Association had won an injunction against the publishing of the electoral roll on similar grounds. At the same time, there are also forums, such as HK Leak, created to aid the hunt for the details of journalists and protestors.
It is believed these forums are linked to the Chinese Communist Party as they are promoted on official Weibo sites such as those of the Chinese Communist Youth League and China Central Television (CCTV).

'Bulletproof' sites - sites registered on servers outside Hong Kong - have provided good protection for these netilantes. For example, HK Leak was registered on a Russian server, which made criminal investigation difficult and time-consuming. ${ }^{4}$

In Hong Kong, any return to social stability will require the rebuilding of trust between the police force and the citizenry. The latter will not stop doxing while ever there is the perception that the police are using illegal methods, including excessive force and triad connections, to control the populace and as long as activists and journalists are themselves targets of doxing by supporters of the police. 


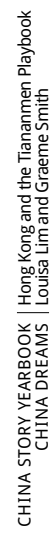




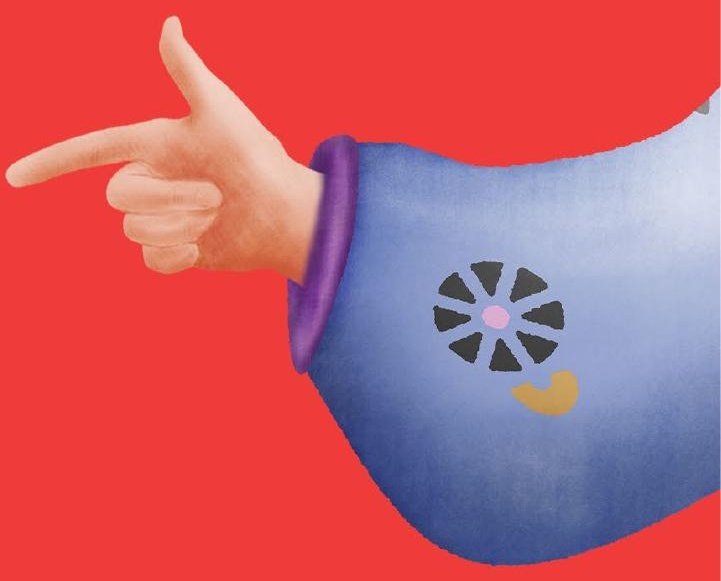




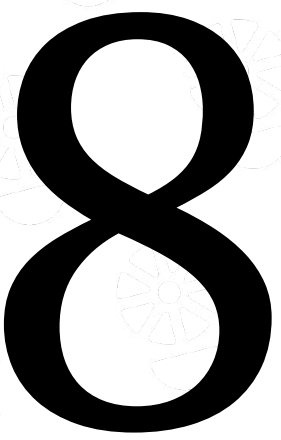




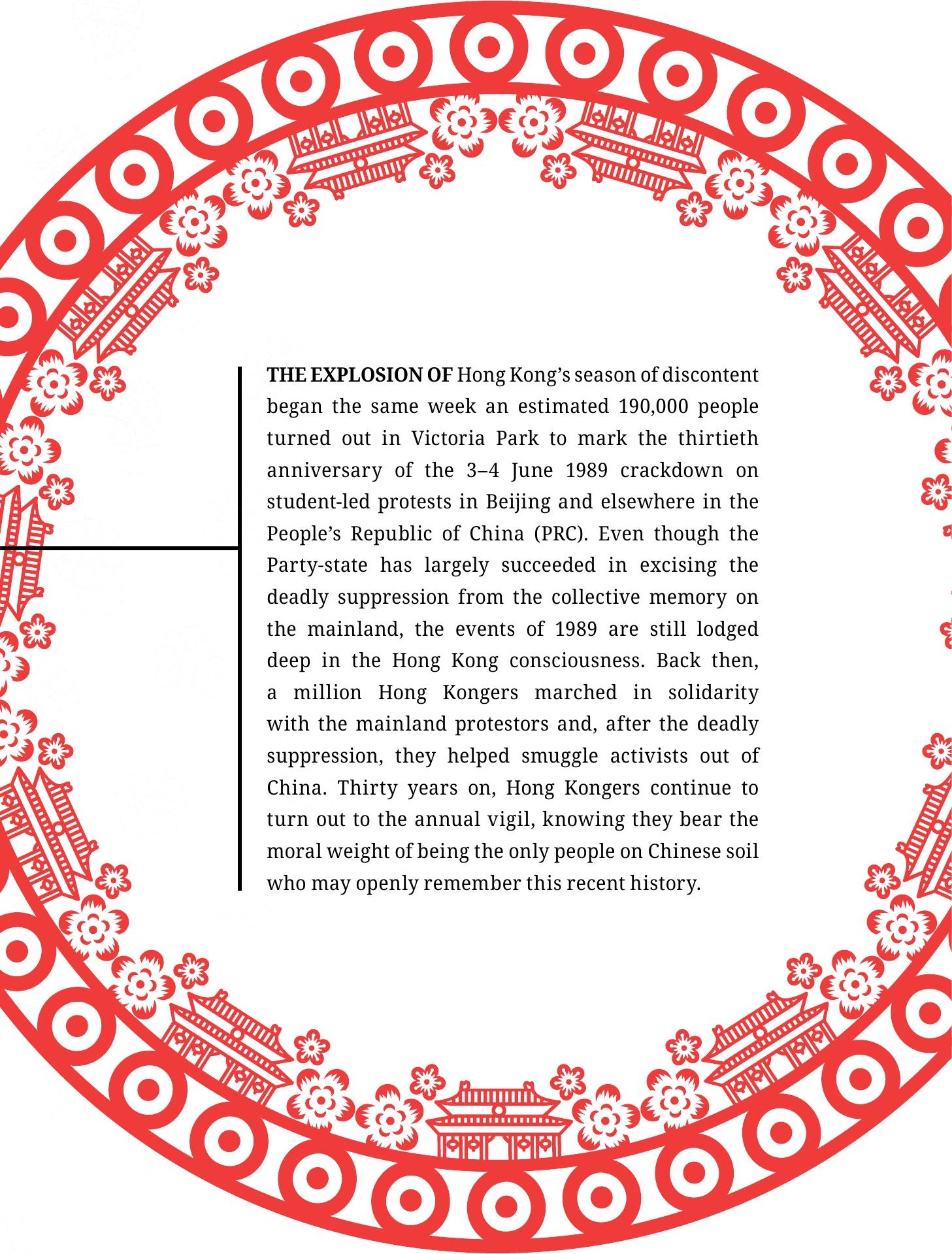


Just five days after the 2019 commemoration, a million people congregated at the same spot to march against the extradition bill. It was a protest path - Victoria Park to the Legislative Council building in Admiralty - that became well-trodden over the following months by crowds that swelled to an estimated two million people at one point (for details of the protests, see Chapter 2 'Hong Kong's Reckoning', pp.51-67).

The massive protests were covered intensely by the international media. What received less coverage was the appearance that same week of a small volume that does much to explain Beijing's response to the ongoing crisis in Hong Kong - a slim book printed by Hong Kong's New Century Press 新世紀 called The Last Secret: The Final Documents from the June Fourth Crackdown 最後的秘密一一共十三屆四中全會「六四」結論文. ${ }^{1}$ It is a collection of speeches and notes leaked by an anonymous official and written by China's leadership at two extraordinary meetings of the expanded Politburo on 19-21 June 1989 to consider the events of that

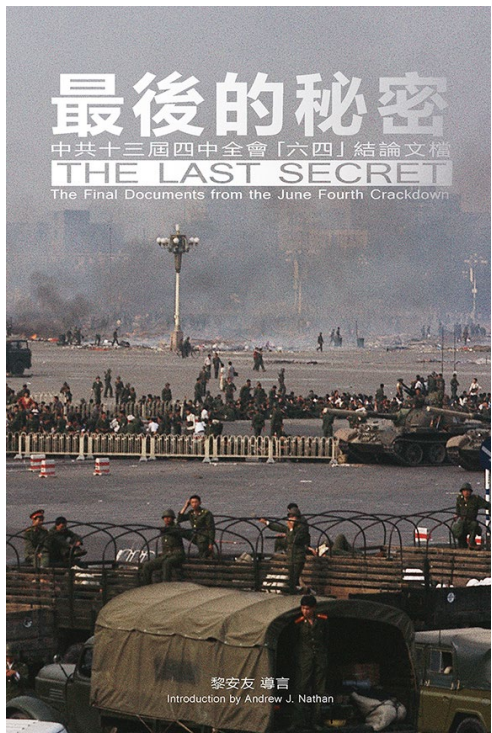

The Last Secret book cover Source: New Century Press month, create a strategy to prevent a recurrence, and set China's future political course. The speeches were printed and circulated among 500 officials at a meeting held a few days later. As a classified document, all copies were meant to be collected afterwards. One copy remained at large.

In the introduction to The Last Secret, the author (using the pen name Wu Yulun 吴禹論) remarks that operational flexibility underpins the longevity of the Chinese Communist Party (CCP) and explains the logic of the meetings held in the wake of Tiananmen: 
This kind of process, usually involving purges, is the key mechanism by which a Stalinist party remains in power. Its primary purpose is to ensure that the one-and-only supreme leader remains in charge, often with total disregard for any purported ideology, existing laws or institutional regulations. It is for this reason that these procedures have always been regarded as the most top secret by the Party. Thus, not only do these documents reveal the 'last secret' of the Tiananmen protests of 1989, they reveal what may well be the ultimate secret of how the Party stays in power to this day.

The book lifts a thirty-year-old veil on the aftermath of the violence in Tiananmen Square. As events in Hong Kong unfolded in 2019, it became increasingly clear just how much China's rulers are still informed by the Tiananmen playbook thirty years on, despite Hong Kong's own particular political proposition. As the protests continued to grow, Beijing's rhetoric, its on-the-ground tactics, and the solutions endorsed all seemed to hew close to the Tiananmen model. Andrew Nathan summed up the lessons the Party learned thirty years ago:

First, that the Chinese Communist Party is under permanent siege from enemies at home colluding with enemies abroad; second, that economic reform must take a back seat to ideological discipline and social control; and third, that the party will fall to its enemies if [it] allows itself to be internally divided. ${ }^{2}$

China's position in the world may have changed dramatically since 1989, but these lessons still hold true today.

\section{The Rhetoric of 'Black Hands' and 'Turmoil'}

Beijing signals its mindset through its rhetoric, and the language deployed regarding Hong Kong draws explicitly on the Tiananmen lexicon. On 
12 June 2019, Hong Kong police fired tear gas and beat protestors who had been blocking lawmakers from reaching the Legislative Council for the second reading of the contentious extradition legislation. Chief Executive Carrie Lam then characterised the events on the street as a 'riot' 暴動. That designation echoed the label of 'turmoil' 動亂 given to student protests in the 26 April 1989 editorial in the People's Daily. In both cases, the designation inflamed the situation, swelling the size of the marches and sparking a new demand from protestors - namely, the withdrawal of the terms 'riot' and 'turmoil'. The fact that Hong Kong, and not Beijing, officials used such terminology strengthened suspicions that Hong Kong policy was being dictated from Beijing, or at least from its representative office in the territory, the Liaison Office of the Central People's Government.

The recycling of Tiananmen-era phraseology illustrates how Beijing continues to fall back on its instinct to blame unrest on a small number of people with ulterior motives. In 1989, the Party-state consistently blamed 'black hands' 黑手 or 'a very small number of turmoil organisers and plotters' for whipping up the students. In 1989, those 'black hands' included the disgraced Communist Party secretary general Zhao Ziyang 趙紫陽, whose fate was sealed at that 19-21 June meeting and who spent the next sixteen years under house arrest; physicist Fang Lizhi 方勵之, who subsequently fled to the United States; cultural critic and later Nobel Peace Prize laureate Liu Xiaobo 劉曉波; and democracy activist Chen Ziming 陳子明; as well as the Voice of America, and Hungarian American financier George Soros.

In 2019, the term 'black hands' re-emerged. The Chinese state broadcaster CCTV labelled US Consul-General Julie Eadeh a 'behind-thescenes black hand creating chaos in Hong Kong' after she held a meeting with pro-democracy politicians including Nathan Law 羅冠聰 and Joshua Wong 黄之锋. State-run media also accused a number of foreign bloggers and journalists of being US Central Intelligence Agency (CIA) agents, while nicknaming four senior pro-democracy figures - Martin Lee 李柱銘, Albert Ho 何俊仁, newspaper tycoon Jimmy Lai 黎智英, and former civil 
servant Anson Chan 陳方安生 - the 'Gang of Four' and accusing them of being 'agents for Western anti-China forces'. Singling out small numbers of instigators deflects attention from the protestors' actual demands. One key difference between 1989 and 2019 is the Party's use of social media to seed and spread these allegations among Chinese-speaking communities worldwide. In 2019, these disinformation campaigns - using Twitter and Facebook as well as WeChat - have caused deep rifts between overseas Chinese and Hong Kongers around the world.

Writing of the Party's response to the 2008 Lhasa protests, Ben Hillman could have been describing present-day Hong Kong:

The CCP's identification of protestors as antagonists with links to 'hostile forces' gives local authorities limited political space to show tolerance toward protestors. Sympathizers risk being accused of disloyalty. It also discourages local officials from experimenting with conflict-sensitive social and economic policies lest they be accused of stoking Tibetan ethnic consciousness or nationalism. This has also resulted in decreased cooperation between local governments and local and international NGOs [nongovernmental organisations], further limiting the space for public debate and policy influence. ${ }^{3}$

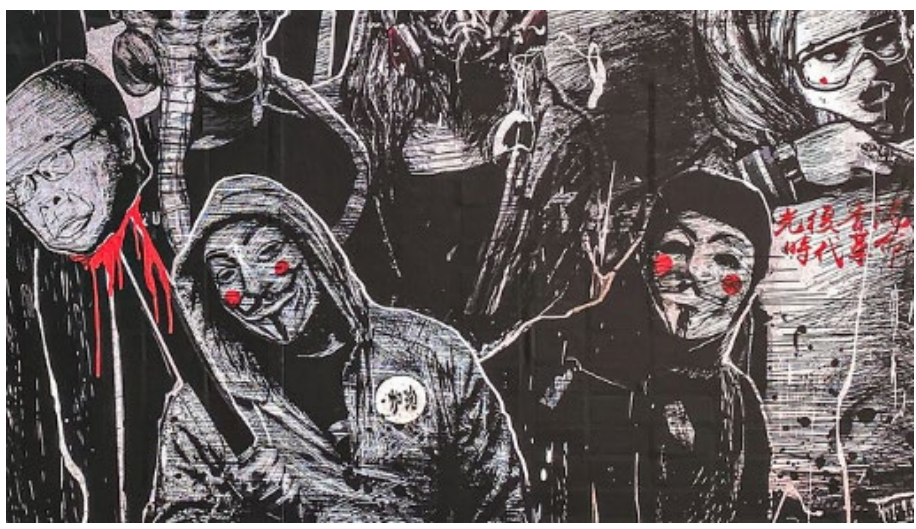




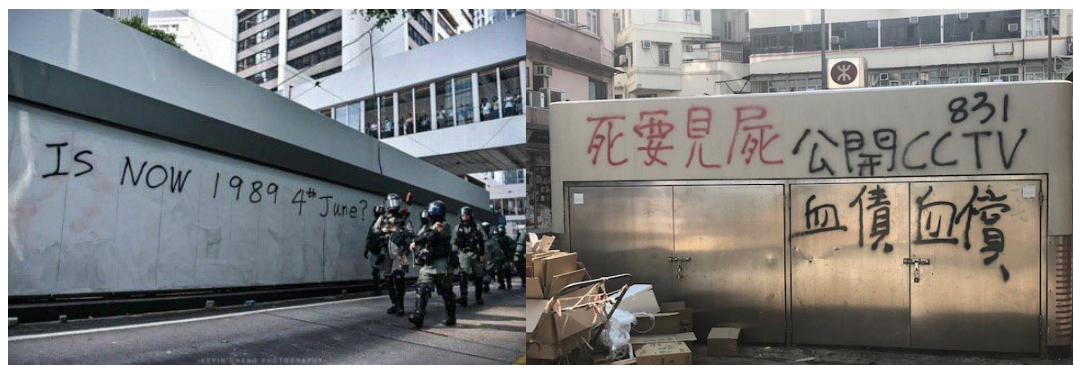

'Is now 1989 4th June?' and 'Blood Debts will be Repaid in Blood' graffitis Source: Louisa Lim

\section{Tiananmen in the Popular Imagination}

The spectre of Tiananmen has been a consistent motif both in the Hong Kong popular imagination and in the protest movement's presentation of itself. The movement has drawn inspiration and imagery from sources including Japanese anime culture, actor Bruce Lee, and Hollywood movies such as $V$ for Vendetta. But Tiananmen-era imagery is ever-present in the use of tanks and People's Liberation Army (PLA) soldiers in posters and memes.

When a Hong Konger stood in front of a policeman with a loaded gun, the media dubbed it Hong Kong's 'Tank Man' moment, and Hong Kongers have used language explicitly linking their movement with 1989. One example is graffiti on the Prince Edward Mass Transit Railway (MTR) station, where unsubstantiated rumours held that police beat someone to death. Spraypainted on the wall was early twentieth-century writer $\mathrm{Lu}$ Xun’s phrase ‘Blood debts will be repaid in blood’ 血債血還, which was so often used in connection with the 1989 deaths.

When riot police besieged students inside the Polytechnic University in late November 2019, lobbing tear gas and firing rubber bullets to stop them from escaping, graffiti appeared on a prominent advertising hoarding, reading: 'Is now 1989 4th June?' Such messages are a vivid reminder that Hong Kongers have access to Western history books and 
may publicly remember the Tiananmen anniversary at the annual vigil, unlike mainlanders, most of whom do not share collective memories of the events due to effective government censorship.

\section{'Life or Death Struggle'}

In both cases, the Party has portrayed the stakes in existential terms. In August 2019, Wang Zhimin 王志民, director of the Liaison Office of the Central People's Government in Hong Kong, said the turmoil represented a 'life or death fight for the very future of Hong Kong' and warned there could be 'no retreat'. This echoes language from 1989, when the protests were described as a 'struggle involving the life and death of the Party and state'. Such language, which is designed to mobilise domestic and diaspora support for the Party, also underlines how seriously the Party views the threats posed by large-scale protests.

The Last Secret reveals the existential anxiety that animated the speeches of party bosses in 1989, dovetailing with a fear of external forces, real or imagined. Only strict adherence to Deng Xiaoping's Four Basic Principles - upholding socialism, the 'people's democratic dictatorship', the Party, and Marxism-Leninism-Mao Zedong Thought — could safeguard the Party from destruction. According to The Last Secret, party elder Peng Zhen 彭真 meanwhile contended:

In reality, the enemy forces at home and abroad who hated and wanted to destroy our socialist system have not ceased for one day their struggle against us, have not ceased for one day their activities to overthrow our state. The painful lesson for us is that these riots are the result of their long-term, deliberate fabrications.

His solution, which implicitly criticised Deng's leadership, was to end the neglect of ideology. Peng noted: 'For many years our party has not engaged in a systematic, thorough-going, all-round rectification of 
thinking, organization, and work styles.' Thirty years later, President Xi Jinping took up this task with vigour.

\section{The Solution}

If the rhetoric sounds familiar, so too do the solutions. In 1989, five days after the crackdown, Deng Xiaoping said the Communist Party's biggest failure was one of political education. This led to the birth of the patriotic education program - an ideological education campaign that continues to this day.

In 2019, senior pro-Beijing figures in Hong Kong returned to this theme, repeatedly blaming the protests on failures in the education system. One pro-Beijing advisor, George Lung Chee-Ming 龍子明, argued: 'A small minority of young people do not recognise their country, and are affected by "Hong Kong independence" because they are sick, and patriotic education is a good cure for such sickness.' Yet it was the attempt to introduce 'national and moral education' to Hong Kong's curricula in 2012 that created the student-led movement that brought young activist Joshua Wong to prominence. But pro-Beijing politicians take their cautionary tales from Beijing's textbooks rather than Hong Kong's recent history.

Thirty years ago, China's leaders - even those known to be more liberal - were prescribing similar medicine. The Last Secret quotes Li Ruihuan 李瑞環, then party secretary of Tianjin, as he catalogued a host of social ills:

A variety of problems are emerging in society, such as corruption, bad social customs, 'look to money in all things', a lack of interest in ideals, a lack of interest in morality. There are many reasons for this, but we have to recognise the bad consequences of having weakened party leadership and ignored political thought work over these past few years.

There are chilling signs, however, that the official rhetoric could be shifting from the Tiananmen lexicon to the Xinjiang playbook. Towards 


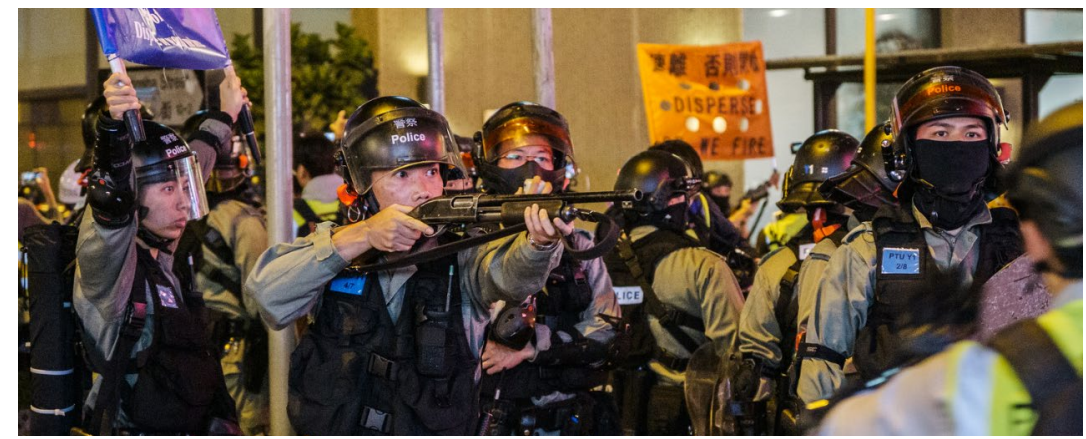

Hong Kong police at protests

Source: Studio Incendo, Flickr

the end of 2019, state-run media began referring to demands for liberal democracy in Hong Kong as an 'infection', echoing moves to pathologise Islam in Xinjiang, where as many as one million Uyghurs are in political indoctrination camps, according to credible reports received by the United Nations. An editorial in the China Daily in November 2019 explicitly made this comparison:

The problems of Hong Kong and that of terrorism have similar causes: lack of realistic economic opportunities and misguided ideology. Regarding terrorism, China has shown the world a more effective and humane approach than that pursued by other countries.

The editorial posited that a 'weakened immune system' can only be healed by the education of 'corrigible' youngsters, raising the chilling prospect of Xinjiang-style political re-education in Hong Kong. (See the China Story Yearbook 2017: Prosperity, Chapter 9 'Prosperity and Freedom: Hong Kong’s Dilemma', pp.295-307.)

\section{The Role of Police}

As Hong Kong's protests continue, one clear parallel is not the crackdown in Beijing in 1989, when the PLA opened fire on the people, but the lesser-known contemporaneous suppression of protestors in Chengdu, 
when the People's Armed Police (PAP) dispersed people with batons and water cannon. According to official propaganda, eight people were killed in the Chengdu crackdown, ${ }^{4}$ though recent documents released in the United Kingdom hint that the real number of deaths in Chengdu could be as high as three hundred. In Chengdu, the PAP purposely beat protestors over the head, and hospital corridors were crammed with people suffering head injuries.

In Hong Kong, the brutal methods of the police have echoed some of the Chengdu tactics. In 2019, both Beijing and Hong Kong understand all too clearly the political cost of deploying the PLA against ordinary citizens and have firmly resisted such a move. But when Hong Kong police removed their identification badges, there was speculation that their ranks had been swelled by PAP from China. In October, Reuters reported that Beijing had doubled its troop presence in Hong Kong, including with elements of the PAP. Anecdotal evidence includes footage of mainland police being transported over the border carrying anti-riot gear marked with simplified Chinese characters, suggesting their mainland origin.

\section{The Lessons of Tiananmen}

One lesson from Tiananmen was the political cost of declaring martial law, which included costly international sanctions, opprobrium overseas, and resentment towards the army at home. By using the colonial-era Emergency Regulations Ordinance, Lam managed to impose a de facto curfew in October 2019 without declaring martial law. The ordinance has enabled the Hong Kong government on occasion to shut down entire public transport networks, stop university and school classes, and withhold permission for public marches - in effect, banning public assembly. People have been detained in the lift lobbies of their own apartment blocks or while walking back to the office after lunch break. A formal declaration of martial law has thus proved unnecessary. The flip side has 
been a collapse in public trust in both the police and the government. Once eroded, public trust is unlikely to recover, even if the Party replaces Lam with a more popular chief executive.

The post-Tiananmen dream that emerged after Deng's Southern Tour of 1992 was an implicit bargain, whereby the state could buy stability with the promise of economic growth. This bargain - combined with intense investment in the apparatus of 'stability maintenance', which includes internal security agents and domestic surveillance - has worked to suppress mass expressions of dissent within China's urban areas, although this may also be due to more effective control of information and harsh treatment of activists. While there is still unrest in rural areas often linked to corruption and the expropriation of farmland - protests are nearly always contained within county lines. And even relatively well-known protests such as those in Wukan 鳥坎 in Guangdong, where participants demanded more democracy, have not had a significant impact on the stability of rural institutions.

The post-Tiananmen bargain has been less than effective in China's restive peripheries, from Tibet to Xinjiang and now Hong Kong, where other sources of information are available and other futures can be imagined. While the Internet is ruthlessly censored, and sometimes disconnected entirely in Tibet and Xinjiang, Tibetans can identify with a nation led by His Holiness the Dalai Lama and the Dharamshala-based government in exile, while exiles from Xinjiang may feel stronger ties with their Turkic brethren than with Communist Party leaders in far-off Beijing. In Hong Kong, one method of providing an economic impetus to the territory has been allowing access to increased numbers of mainland tourists, yet this has not been welcomed by Hong Kongers, who fear the disruption caused by an influx of mainland tour groups. For Hong Kongers, whose per capita material wealth is nearly five times that of China's citizens, and whose economic success has been built on British rule of law and their own endeavours, trading liberty for economic wealth holds limited appeal. Campaigns to instil ideological rectitude are even more of a non-starter. 


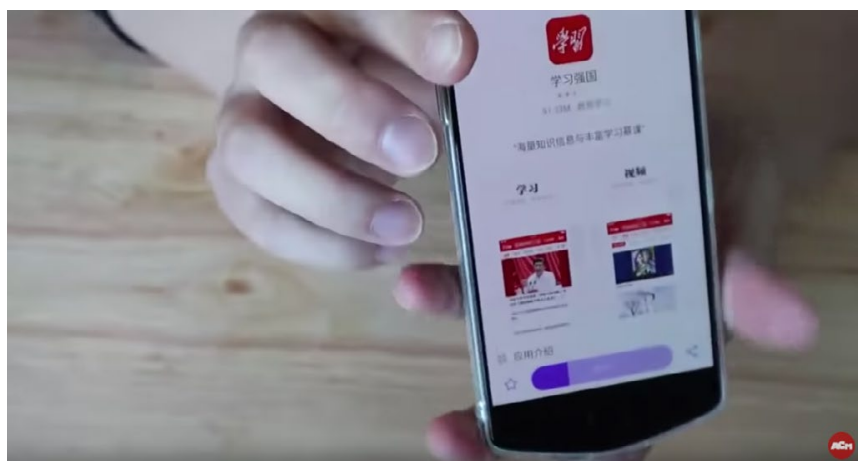

The 'Study Xi-

Strong Nation' app

Source: ACM Tube,

YouTube

Yet in the wake of a humiliating defeat for pro-Beijing candidates in Hong Kong's district elections, which left pro-democracy candidates controlling seventeen of Hong Kong's eighteen district councils, Beijing is more likely to favour rectification over concessions.

The dilemma for the Hong Kong administration is that it is effectively boxed in. In a leaked speech, Lam lamented her own lack of autonomy. She noted that Beijing was 'willing to play long, so you have no short-term solution. Hong Kong suffers, you lose tourism, economy, you lose your IPOs [initial public offerings] and so on, but you can't do much about it.' With Hong Kong already in recession, this could have a longer economic impact than the two years of economic stagnation that China suffered in the wake of Tiananmen, when growth slowed from more than eleven percent to around four percent per year, as foreign businesses and investors stayed away. In Hong Kong, the protest movement - which has targeted proBeijing businesses - has not shied away from actions that might hasten the territory's economic decline. One plank of Beijing's response, as some Chinese scholars are advocating, might be to accelerate Hong Kong's integration into the Greater Bay Area, an economic entity encompassing Hong Kong, Macau, and nine other cities in southern China.

The Last Secret reveals how elderly generals and officials took turns to condemn party chairman Zhao Ziyang for siding with his favoured 'think tank intellectuals' who advocated economic liberalism, while ignoring 
the essential task of party building, which was code for enforcing greater ideological rigour on party members. The generals' aspirations are finally being met by today's President, whose 'Study Xi - Strong Nation' 學習 強國 app is now used to track and rank the ideological enthusiasm of party members in real time. Thirty years ago, nonagenarian Marshal Nie Rongzheng 聶榮政 proposed a solution that would have met with Xi’s approval:

We should sum up the experience of the political thought work of the 1950s, carry forward the Party's outstanding traditions, thoroughly rectify the atmosphere inside the Party, unify the masses, revitalize the national spirit, and promote patriotic thought.

But Nie was more explicit than most of his colleagues in naming what was going to keep the Party in power: violence. Recalling Mao's words in 1949, he reminded his colleagues that the people's dictatorship could only vanquish enemy forces because of its power as

a tool of repression, of violence, it's nothing to do with 'benevolence 仁慈'... The last forty years have shown that whenever the dictatorship of the people prevails, the nation is peaceful, united and flourishing. When it founders, turmoil and suffering ensue.

As Carrie Lam now refers to students as 'enemies of the people', the state apparatus seems to be grinding inexorably towards a national security solution that could include more violence but will almost certainly boost patriotic and ideological education for Hong Kongers. The bargain of buying stability with economic growth has held on the mainland for three decades, but the idea that this type of post-Tiananmen solution could also be applied in Hong Kong is likely to be a pipedream; Hong Kong had both economic growth and stability before the return to mainland sovereignty and, so long as its people are free to remember and write their own history, they are unlikely to buy into such a 'bargain'. 
论坛 

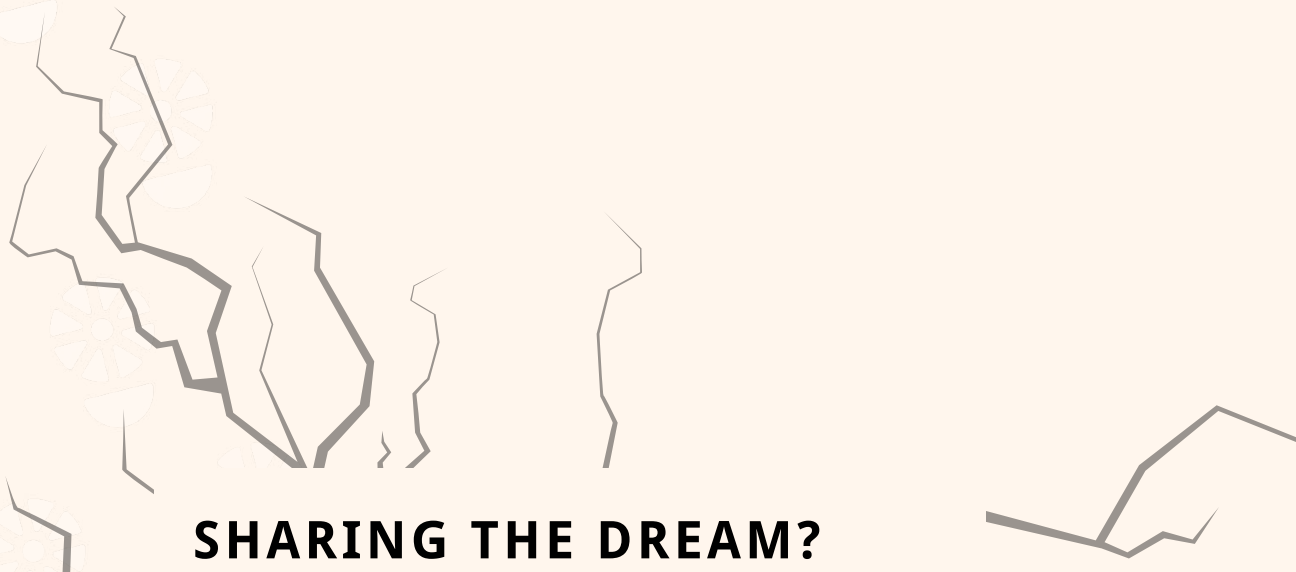

South Korea and the 'China Effect'

- HYUNG-GEUN KIM

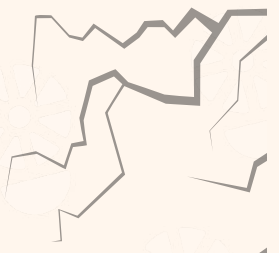

Taiwanese Dreams: Security, Sovereignty, and the Space to be Seen

- CHIUNG-CHIU HUANG
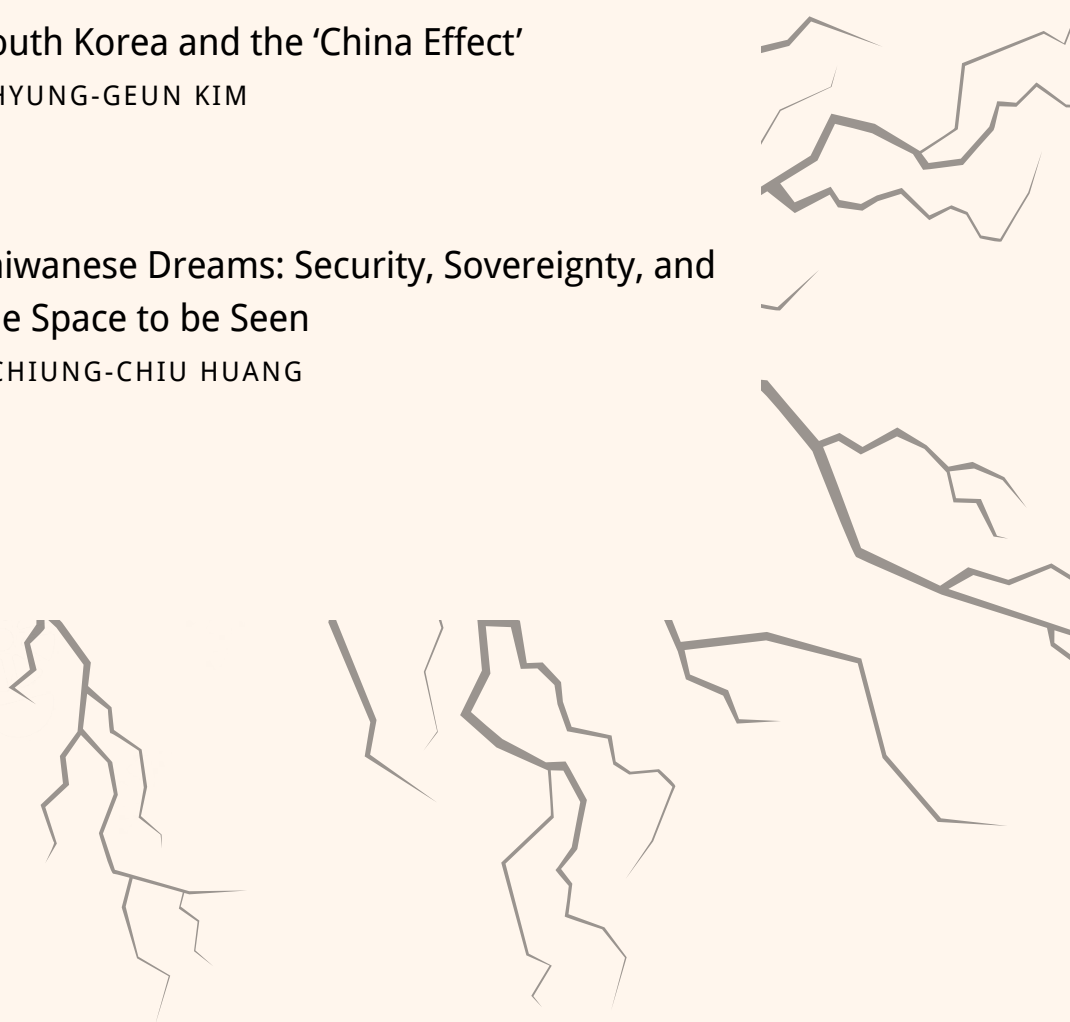


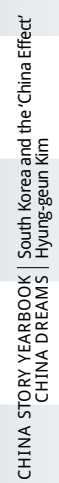




\section{SOUTH KOREA AND THE
"CHINA EFFECT'
Hyung-Geun Kim}

W

THEN THE FOREIGN ministers of South Korea, the People's Republic of China (PRC), and Japan met in Beijing on 21 August 2019, Chinese Foreign Minister Wang Yi offered to help South Korea and Japan settle their simmering trade dispute. The dispute over security controls on Japanese exports to South Korea had spiralled into an argument about Japan's use of forced Korean labour in World War II. In 2019, relations between Tokyo and Seoul reached their lowest point in decades. South Koreans are boycotting en masse Japanese-made goods such as cars and beer. Now China has offered to mediate. Does Beijing's overture signal the end of China's recently aggressive posture towards South Korea? Could China become a peacemaker in north-east Asia, where the faultlines of the Cold War still divide the Korean Peninsula?

The answers to those questions are complicated for South Korea. Like Australia, South Korea's major security partner is the United States, but its major trading partner is China. Rising tensions between the United States and China put South Korea in a difficult position. Korean commentators liken its situation to 'a shrimp caught between big whales', as the Korean saying has it: 'when whales fight, they break the shrimp's back'. In recent years, the US government has become increasingly concerned about China's rising economic and political influence in north-east Asia. South Korea has firsthand experience of 
how the Chinese government can use its economic power to apply political pressure. In 2017, following the deployment on the Korean Peninsula of the US Terminal High Altitude Area Defense (THAAD) system, Chinese state media encouraged a consumer boycott of South Korean goods to signal China's displeasure with South Korea's decision. The hardest hit South Korean company, discount store chain Lotte Mart, accrued operating losses of US $\$ 224$ million, while Hyundai's sales in China dropped sixty-four percent in the second quarter of 2017 from a year earlier. As a result of a ban on Chinese tour groups travelling to South Korea, tourism-related industries suffered an estimated revenue loss of US $\$ 15.6$ billion that year, and even though tourist numbers recovered in 2019, they were still much lower than in previous years. ${ }^{1}$ The political ramifications of Beijing's displeasure with South Korea have also been significant. For example, the KoreaChina Defence Strategic Dialogue, which was held regularly from 2011 to discuss military cooperation between the two countries, has not been held since the tensions began.

At the same time, South Korea maintains other close economic ties to the PRC. It joined the Asian Infrastructure Investment Bank (AIIB) in 2015, but it has not yet signed up to the Belt and Road Initiative, although President Moon Jae-in declared his interest in doing so in 2018. Moon has also actively promoted better ties with

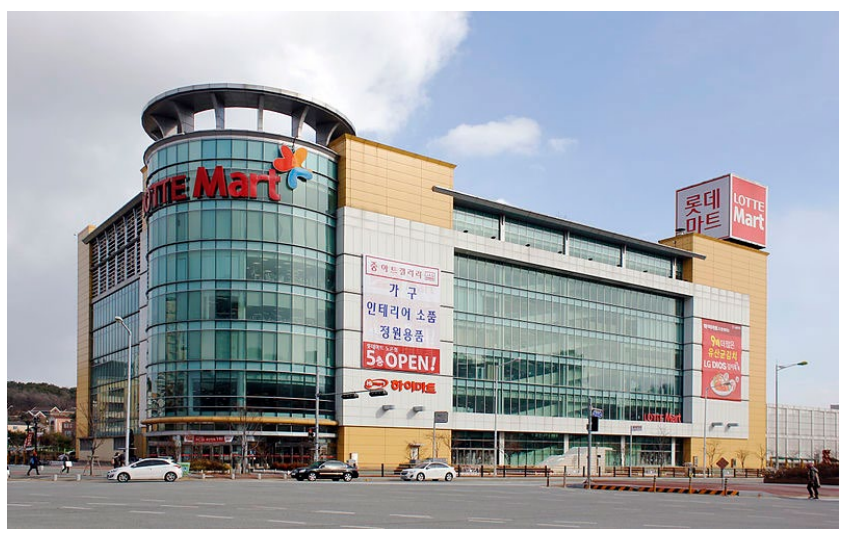




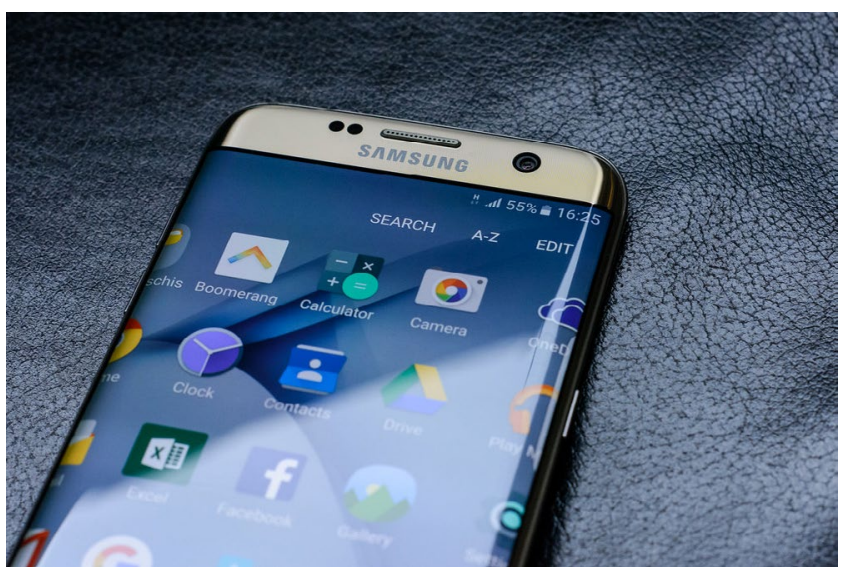

Large South Korean firms such as Samsung, Kia, and Hyundai are already scaling back investments in China Source: Răzvan Băltăreţu, Flickr

North Korea, so it is not surprising that, under his watch, relations with Japan have soured. Washington, too, has watched these developments warily.

Washington is also watching closely South Korean trade with China, especially in advanced technology sectors. In June 2019, American Ambassador to Seoul Harry Harris told the Chosun newspaper that the United States was 'naturally concerned' about any plans for Huawei's involvement in South Korean 5G networks. Washington did not want to 'expose sensitive security information to an unacceptable risk level' and would need to 'reevaluate how we share information with allies'. The United States currently stations almost 30,000 troops in South
Korea to bolster its defences against the north. South Korea can scarcely afford to lose the umbrella of US protection. At the same time, however, Huawei alone accounts for seventeen percent of South Korean electronic parts exports to China. Perhaps Wang Yi's offer of assistance to solve the KoreaJapan conflict - following so soon after Harris expressed his concerns - was a reminder to South Korea that China could play a protective role in the region, too? Regardless, for Korea, there are no easy solutions. ${ }^{2}$

Caught between the whales, South Korea is seeking to reduce its reliance on trade with China and reconsider its investment strategies. ${ }^{3}$ Large South Korean firms such as Samsung, Kia, 
and Hyundai are already scaling back investments in China, partly to manage political risk and partly because China's own firms have become more competitive in the personal electronics and automobile industries. To hedge against the downsides of trade with China, South Korean policymakers are considering a range of institutional and cooperative frameworks to strengthen trade and investment relationships with other countries in the region, including members of the Association of Southeast Asian Nations (ASEAN).

Both China and the United States expect — and sometimes even demand - practical cooperation from South Korea across a number of issues. South Korea would be wise to give China some of what it wants, such as higher participation in the Belt and Road Initiative, in return for what
Seoul needs, such as cooperation in the ongoing efforts to denuclearise the Korean Peninsula and find a diplomatic solution. At the same time, until that solution is found, Seoul will likely try to keep its American ally by its side. South Korea's future relies on maintaining a delicate balancing act, as well as the ability to achieve greater independence both economically and in terms of security from the two 'whales' - not an easy call. But as Parag Khanna, author of the book The Future Is Asian, told The Atlantic's Michael Schuman: 'No one wants to choose sides. We live in a multipolar system. No smart country sides with only one power. Instead they play all the powers off each other to derive maximum benefit for themselves. ${ }^{4}$ 



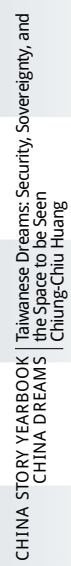




\section{TAIWANESE DREAMS:
SECURITY, SOVEREIGNTY,
AND THE SPACE TO BE SEEN
Chiung-Chiu Huang}

T The START OF 2019, marking Athe fortieth anniversary of Beijing's call in 1979 for an end to military confrontation across the Taiwan Strait, Chinese President Xi Jinping expressly linked unification to the 'national rejuvenation' that is at the heart of his much-promoted notion of the China Dream. He called for 'in-depth democratic consultations for a cross-strait relationship ... and transitional arrangements for the peaceful development of cross-Strait ties'. Taiwan's President Tsai Ing-wen responded by stating that Taiwan would not cede its sovereignty.

In Taiwan - the region with the most complicated ties with the People's Republic of China (PRC) - the China Dream has not been warmly embraced. Beginning in 2013, when Chinese authorities began promoting the slogan, many Taiwanese commentators charged that it concealed a plan to force Taiwan's 'reunification' with the mainland. The then minister of the Mainland Affairs Council of Taiwan, Chen MingTong, is reported to have said that 'the Taiwanese Dream and the China Dream are mostly incompatible with each other'. ${ }^{1}$ According to Chen, the Taiwanese Dream is about security, sovereignty, and human rights, and China cannot accept such 'dreams'.

The China Dream seems in some ways like a duplication of the American Dream; even Xi himself claimed on a visit to Seattle in September 2015 that the China Dream 
parallels the American Dream. As Jeffrey Wasserstrom notes, at the core of the American Dream are the 'tales of individuals and families bettering their situations through their own efforts'. Xi's China Dream also encompasses this. However, while the American Dream emphasises individualism and requests that political authorities get out of the way, the China Dream emphasises the role of the state and the Chinese Communist Party in enabling people to pursue better lives.

Xi's proposed rejuvenation of the great Chinese nation poses practical as well as ideational challenges for Taiwan. A standout example of China's pursuit of national rejuvenation on the world stage is the Belt and Road Initiative. For the Government of the Republic of China in Taipei, resisting the initiative could result in the loss of Taiwan's position in the global economic chain. At the same time, wholehearted participation in the scheme would mean buying into the China Dream, and potentially ceding to Beijing's leverage that might be used to force talks on unification.

Taipei has tried different strategies to hedge against a hegemonic Chinese national rejuvenation; it has tried (and failed) to join the TransPacific Partnership and the Regional Comprehensive Economic Partnership. But Taiwan has been more successful in building an international profile as a great place for doing business (in contrast with the mainland). Taiwan ranked thirteenth out of 190 jurisdictions listed in the World Bank's 2019 Ease of Doing Business Index. The $\mathrm{PRC}$ is far behind in forty-sixth place. And Taipei's New Southbound Policy aims at strengthening the island's ties with eighteen countries in South and South-East Asia and Australasia, including Australia and New Zealand. It promotes cooperation in trade, technology, agriculture, medicine, education, and tourism.

China's perceived aggressiveness in pursuit of national greatness raises other concerns for Taipei. Taiwan is paying particular attention to developments in Xinjiang province and Hong Kong. In August 2019, a commentary posted on The Storm Media discussed the current situation in Xinjiang and Hong Kong, arguing that the China Dream was characterised by 'bullying patriotism'. ${ }^{2}$ The author warned the Taiwanese people of the risks of signing up to the China Dream. 
The 2019 Hong Kong protests triggered by an extradition bill that Beijing said was needed to bring to justice a suspected murderer who committed the crime in Taiwan and hid in Hong Kong - have had a profound impact on Taiwanese society. Taiwan's political leaders have pointed to the Hong Kong protests to highlight the failings of the One Country, Two Systems model (notably, Beijing's failure to respect Hong Kong's semi-autonomy), which is the same model Beijing proposes for Taiwan's reunification with the mainland. Sympathy for Hong Kong protestors prevails; according to a poll released in June 2019, more than seventy percent of Taiwanese support Hong Kong's anti-extradition protests. ${ }^{3}$ In addition to posting comments criticising the Hong Kong police and China on social media, Taiwanese supporters have established 'Lennon Walls' on the campuses of all major universities in Taiwan. Lennon Walls have also suddenly appeared in some of Taiwan's famous tourist spots, although local authorities have been quick to take them down. Lennon Walls and activities organised in support of the Hong Kong protests have angered some mainland Chinese students and tourists in Taiwan. Some have vented their anger by tearing down posters from Lennon Walls. ${ }^{4}$

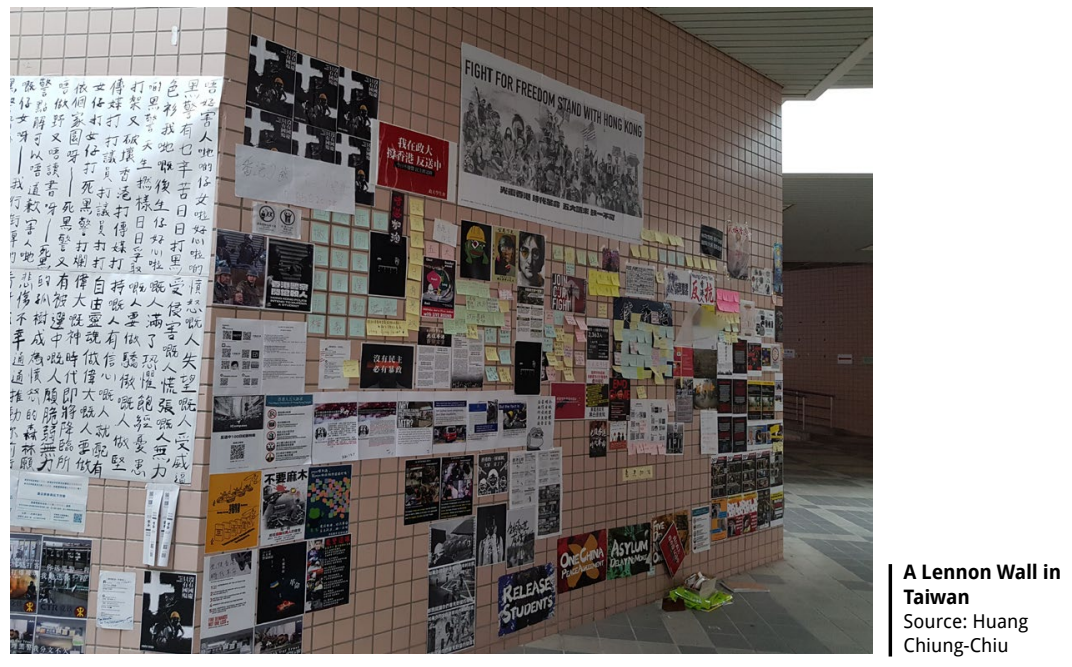


According to the poll conducted by the Mainland Affairs Council of Taiwan in August 2019, more than eighty percent of the Taiwanese population opposes the One Country, Two Systems model for Taiwan's reunification with the mainland. Such surveys highlight a big divide between the Chinese mainland and Taiwan over the China
Dream of national rejuvenation. For many Taiwanese, 'the rejuvenation of the Chinese nation' no longer ends with a question mark, but with an exclamation mark. It is a vision of a Chinese future that many Taiwanese refuse to embrace, preferring instead to leave themselves unrestricted, each to pursue dreams of his or her own. 



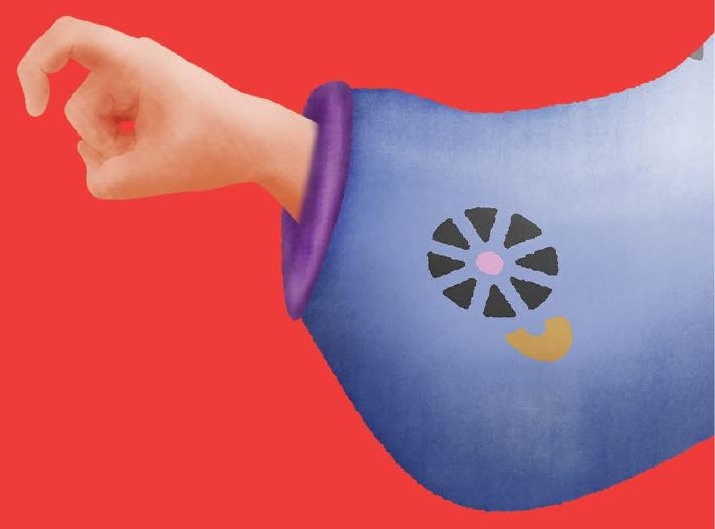




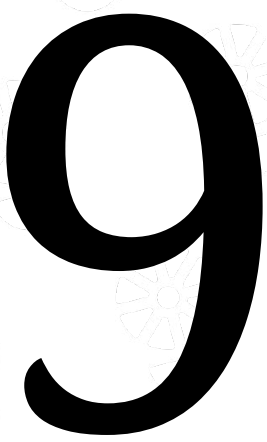




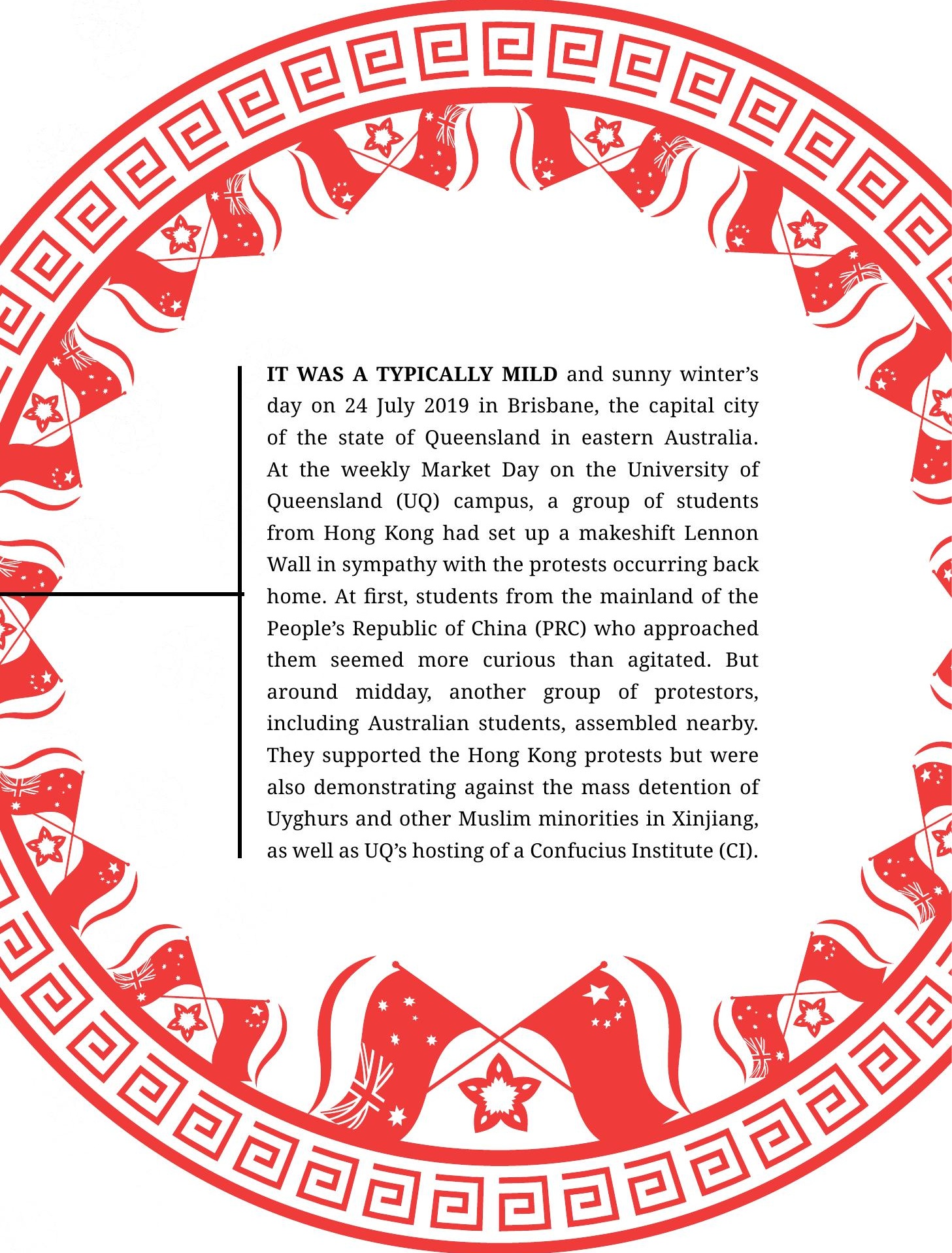


After the leaders of this second group began chanting into megaphones, the situation quickly deteriorated, with abuse being hurled in all directions. A large group of mainland Chinese students began drowning out the protesters' chants with a boisterous rendition of their national anthem blasting out from a speaker of their own. UQ security officers called the police and order was eventually restored. ${ }^{1}$ But UQ's China conundrums were only just getting started.

The next day, China's Consul-General in Brisbane, Dr Xu Jie 徐杰, issued a statement praising 'the spontaneous patriotic behaviour of Chinese students'. ${ }^{2}$ Earlier that month, UQ had appointed $\mathrm{Dr} \mathrm{Xu}$ as an adjunct professor in the School of Languages and Cultures, albeit in an honorary capacity. In the media, questions were raised about whether the appointment of a serving diplomat was consistent with the university's commitment to freedom of speech and academic inquiry, particularly in light of Dr Xu's statement a day earlier. On 26 July, Australian Foreign Minister Marise Payne made it clear that the government expected foreign diplomatic representatives to respect the right to free speech and lawful and peaceful protest, saying she 'would be particularly concerned if any foreign diplomatic mission were to act in ways that could undermine such rights, including by encouraging disruptive or potentially violent behaviour'. ${ }^{3}$ The Chinese Embassy in Canberra replied that Dr Xu's remarks were 'appropriate and measured' and that any 'misinterpretation' and 'overreaction' were 'regrettable and unacceptable'. ${ }^{4}$

The day after the protests, the Nine Network reported on UQ's agreement with Hanban, the Chinese government organisation that manages all CIs and is guided by the United Front Work Department of the Chinese Communist Party (CCP). According to the Nine Network, the agreement required UQ to accept Beijing's authority on teaching matters in courses run by the CI that it hosts. ${ }^{5}$ Between 2013 and 2018, UQ Vice-Chancellor Peter Høj had also acted as an unpaid consultant to Hanban, receiving a formal commendation for his service in 2015. UQ claimed that its CI had no input into award courses. 


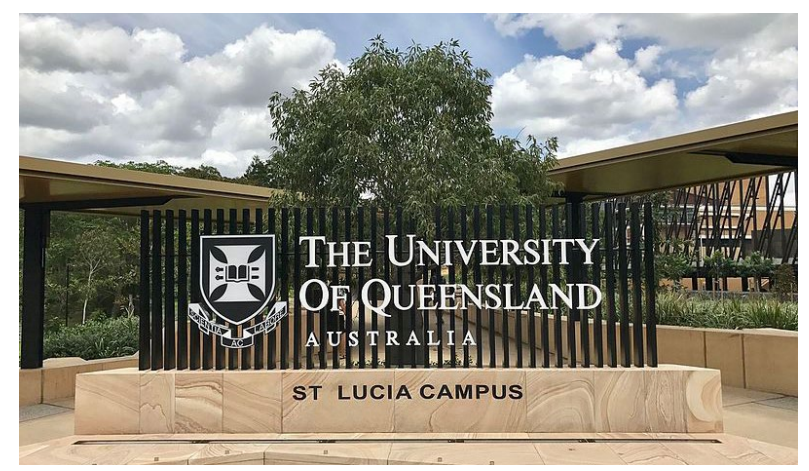

China conundrums at the University of Queensland

Photo: Kgbo, Wikipedia

Controversy also spread to UQ's research programs. In August, Alex Joske, a researcher at the Australian Strategic Policy Institute (ASPI), briefed a journalist at The Australian about a new ASPI report alleging a UQ professor of Chinese origin had set up a company supplying surveillance technologies to a local government in Xinjiang, as well as operating a joint laboratory with the Ministry of Public Security. ${ }^{6}$ The university responded that the academic had left in 2017, although he retained an honorary position. Nonetheless, Joske drew a connection with the researcher's earlier work at UQ. He also cited evidence that the researcher had held multiple positions in China, including as head of a school of computer science and engineering at a university, while still employed at UQ and receiving Australian government research grants - possibly in contravention of funding body rules. ${ }^{7}$

Such were the ferocity and breadth of criticism around UQ's engagement with China that the university felt compelled to set up a dedicated webpage to 'provide clarity'. ${ }^{8}$ UQ Chancellor Peter Varghese, a former Director-General of the Office of National Assessments (now the Office of National Intelligence) and Secretary of the Department of Foreign Affairs and Trade, also came to UQ's defence. Varghese noted that UQ was managing its financial exposure to China by means including the establishment of a contingency fund that could be drawn on in the event of a sudden sharp fall in the number of Chinese students. 
He described allegations that Høj was a CCP stooge as belonging 'more to the anti-communist witch hunts of the McCarthy era in the US than to the rational debate we need to have in Australia'. ${ }^{9}$ While welcoming a dialogue with the Australian government to ensure that the university's international research collaborations did not endanger national security, he also cautioned against 'throwing the baby out with the bathwater'.

UQ is not a unique case in Australia - a country with one of the most internationalised higher education systems in the world. In 2013, international student fees earned Australia AU\$17 billion; by 2018, it was AU\$35 billion. Chinese students are by far the largest group of international students in the country, and are especially concentrated in the leading research-intensive universities, which are known as the Group of Eight. In addition to ensuring free speech on campus and mitigating against an overreliance on fee-paying Chinese students, these universities face an even more complex challenge - hinted at

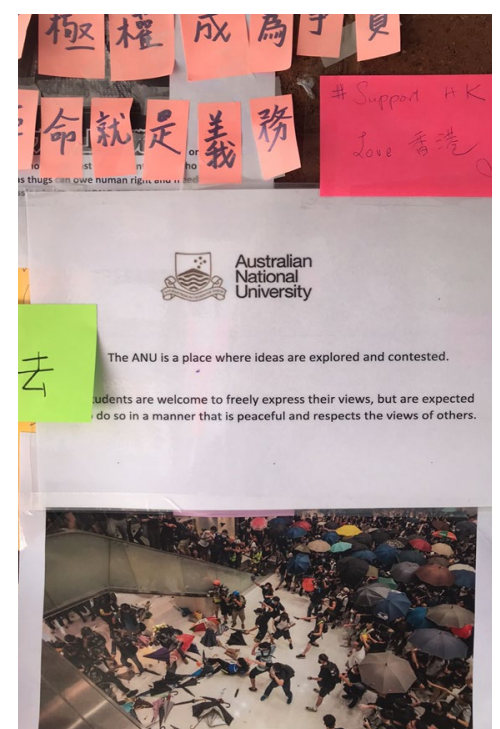

The Lennon Wall at The Australian National University

Photo: Melodie Liu above in the ASPI warning about breaches of funding body rules and Varghese's defence of UQ's research practices. This involves collaborative research, which is also increasingly international.

In April 2018, Senator Payne, then Minister for Defence, announced a review of Australia's Defence Trade Controls (DTCs), which apply to university-based research projects, to ensure the legislative and regulatory framework 'appropriately balances' defence requirements 'while not unnecessarily restricting trade, innovation or research collaboration'. ${ }^{10}$ In November 2018, 
Minister for Education Dan Tehan instigated a review into the state of freedom of speech on university campuses. In August 2019, he announced the establishment of a taskforce charged with the development of best practice guidelines to counter foreign interference in the Australian university sector' ${ }^{11}$ The guidelines were released in November. ${ }^{12}$

\section{Five Eyes on China}

The Australian government is not alone in its concerns. In September 2019, Dr Kelvin Droegemeier, Director of the White House's Office of Science and Technology Policy, using language strikingly similar to that of minister Tehan, called for the development of 'best practices for academic research institutions' in response to countries that had sought to 'exploit, influence and undermine our research activities and environments'. ${ }^{13}$ Just a few days earlier, on 13 September, Assistant US Secretary of State for International Security and Non-Proliferation, Christopher Ford, said his department had been hard at work building international 'coalitions of caution' among friends and allies to protect against 'Chinese technology-transfer threats'. ${ }^{14}$

By the end of 2019, six bills had been introduced to the US Congress proposing tighter screening of Chinese applicants for student visas and stronger measures to address intellectual property (IP) theft and espionage in universities. One draft bill stated that the US government should publish annual lists of research institutions in China 'affiliated with, or funded by, the People's Liberation Army' and deny visas to their associates. The same draft bill also states that Australia and other Five Eyes countries should implement similar measures. Along with discussions of the feasibility and implications of 'decoupling' from China in key technology sectors, there is increasing interest in creating an 'allied innovation zone' with greater research cooperation between the United States and its closest allies. 
These views have been gaining strength in Washington since the release of the US National Security Strategy in 2017, which focused on 'strategic competition' with China. In February 2018, Director of the US Federal Bureau of Investigation (FBI) Christopher Wray testified to Congress about the university sector's 'naïvety' with regard to China's exploitation of the open research and innovation system that the United States has led since the Second World War. In June 2018, the State Department followed up by announcing that Chinese graduate students studying in the United States in key sectors such as advanced manufacturing, aviation, and robotics would henceforth be entitled to only one-year visas instead of five-year visas. The Department of Defense (DoD) told universities they would have to apply for a special waiver if they wanted to maintain a CI as well as having access to DoD funds for foreign language education. After a number of US universities applied for waivers, the DoD announced that it would not be granting waivers after all, making the choice stark. By November, fifteen universities had announced the closure of their campus CIs. In mid-2019, the Department of Energy forbade its staff and grant recipients from participating in foreign 'talent recruitment programs', such as China's Thousand Talents, which Beijing established in 2008 to draw top international science and technology researchers to China. The US Department of Education and major research funding agencies such as the National Institutes of Health have also introduced new rules on foreign funding and conflicts of interest.

The US Department of Commerce, meanwhile, is reviewing whether its export control regime should be broadened to cover a wider range of 'emerging technologies' such as artificial intelligence (AI). Throughout 2019, more than 170 Chinese individuals and organisations - including Sichuan University and leading Chinese technology companies Huawei, Hikvision, IFLYTEK, Megvii Technology, and Sense Time - were placed on the US 'entity list', barring them from dealing with American universities and companies unless they successfully apply for a licence to do so. ${ }^{15}$ 
On 28 September, David R. Stilwell, US Assistant Secretary of State for the Bureau of East Asian and Pacific Affairs, said that US intelligence and law enforcement communities had identified 'an increasing number of instances in which foreign intelligence services had "co-opted" individual academics, researchers and others to conduct intelligence-related activities while in the US'. In the following breath, he cited the FBI's Wray in saying that investigations around IP theft saw 'almost all [of them] leading back to China'. Stilwell also accused China of undermining and exploiting fundamental scientific values such as free inquiry, openness, and ethics for 'unfair gains' such as the theft of IP and 'illiberal and repressive uses' ${ }^{16}$

In response to the rapidly changing landscape, throughout 2019 US universities reviewed and tightened their internal processes to protect IP and ensure compliance with federal legislation while also making a case for the benefits of continued cooperation, and the importance of foreign talent for their ability to do high-quality research. In June 2019, Rafael Reif, the President of the Massachusetts Institute of Technology (MIT), wrote an email to staff that conceded that, across the United States, 'small numbers of researchers of Chinese background may indeed have acted in bad faith'. But, he asserted, bad actors were 'the exception and very far from the rule'. ${ }^{17}$ Indeed, since 2014, charges against at least five China-born scientists have been dropped. ${ }^{18}$ In the second half of 2019, senior MIT leaders spoke out publicly to Washington think tanks about the value to the United States of research collaboration with China, and the MIT campus in Boston was the site of protests by academic staff over what they argued was the unfair targeting of Chinese-American academics.

Meanwhile, bilateral education and research links between the United States and China continued to grow, according to the latest available data. In 2007-08, there were just over 80,000 Chinese students studying at American colleges and universities. By 2017-18, this had grown to 363,000 . Despite a downturn in total international student numbers to the United States in each of the past two years, growth in 
Chinese student numbers has been consistent. By 2018, according to the InCites database, 10.7 percent of scientific papers published in the United States in that year included a co-author affiliated with a Chinese institution. This was up from 8.6 percent in 2016 and just 2.7 percent in 2008. While policymakers in Washington may consider some amount of 'decoupling' as desirable, this can only come at a significant cost financially and intellectually for universities, and also for the Chinese (and potentially Chinese-American) students and researchers who find themselves in the firing line.

\section{Facts and Folly}

For Australia, the costs of decoupling from China would be significant. A report by the Australia-China Relations Institute released in July 2019 showed the dramatic expansion of research collaboration between Australian and Chinese institutions over the past two decades. ${ }^{19}$ In 1998, only one percent of all Australian peer-reviewed articles included a co-author affiliated with a Chinese institution; by 2018, it was fifteen percent. By this measure, China overtook the United States to become Australia's leading international collaborator in 2019. Most Chinese-Australian collaborations are in the physical and computer sciences, whereas American-Australian collaborations tend to be in the life sciences.

The Australian government has long seen the benefit of such collaborations, some of which it funds through the Australia-China Science and Research Fund. ${ }^{20}$ In August 2018, then prime minister Malcolm Turnbull addressed the University of New South Wales (UNSW), praising its 'international partnerships and collaboration, particularly with China'. ${ }^{21}$ Yet not everyone is convinced. In a submission to the recent independent review of DTCs commissioned by the Australian government, Michael Shoebridge, from ASPI, wrote that it is a growing certainty that Australian research partnerships with Chinese 


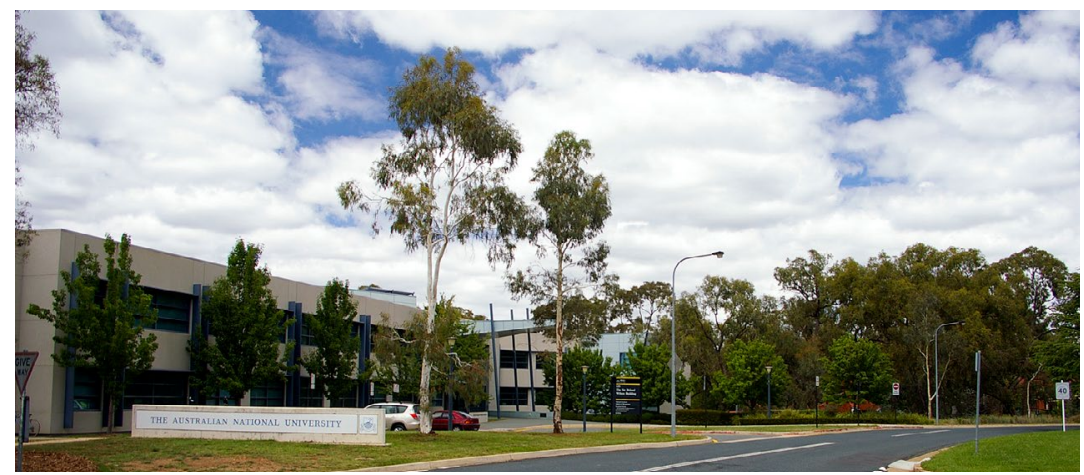

On ABC's Four Corners program, ANU Vice-Chancellor Brian Schmidt was grilled about student activism on campus, cybersecurity, research collaboration, and links to the Chinese government

Photo: Wikimedia Commons

counterparts will be directly advancing Chinese military capability'. Therefore, he said, it is likely that if decisions are made on the basis of national security, there could be many more refusals in future. ${ }^{22}$ John Fitzgerald of the Swinburne University of Technology echoes the concerns of Stilwell when he asserts:

Australian universities are sailing into uncharted waters when they venture into major research collaborations with institutions and systems that do not share their commitment to liberal values and free and open critical inquiry. It is not clear that they are equipped to manage the risks. ${ }^{23}$

In May 2019, a Human Rights Watch (HRW) report documented how a subsidiary of China Electronics Technology Corporation (CETC), a massive Chinese state-owned conglomerate with military connections, had designed surveillance equipment being used in Xinjiang. ${ }^{24}$ Back in the first half of 2017, when the University of Technology Sydney (UTS) announced a research partnership with CETC, ${ }^{25}$ a PhD student at The Australian National University and a researcher at the US Studies Centre raised questions about the national security implications of the 
collaboration. ${ }^{26} \mathrm{UTS}$ responded by noting that all the research it undertook was subject to DTCs. In July, the ABC's Four Corners program followed up, revealing that UTS had launched an internal review of the CETC collaboration in April after being made aware of the soon-to-be released HRW report. ${ }^{27}$ In October, the South China Morning Post obtained a copy of the agreement between UTS and CETC. According to James Leibold, a specialist on Xinjiang at La Trobe University, it showed that: 'UTS is essentially providing CETC with an overseas laboratory for its research in dual-use technologies that are contributing to the advancement of the Communist Party's "security-surveillance complex". ${ }^{28}$

What the UTS review actually found - a summary of which was made publicly available in August - received little media attention. Its academics had engaged in five projects in collaboration with CETC. Only one was potentially relevant to the surveillance technologies being deployed in Xinjiang, yet it was initiated only after HRW had already obtained the problematic surveillance application. Further, all projects had been submitted for approval to the Department of Defence where required under DTCs.

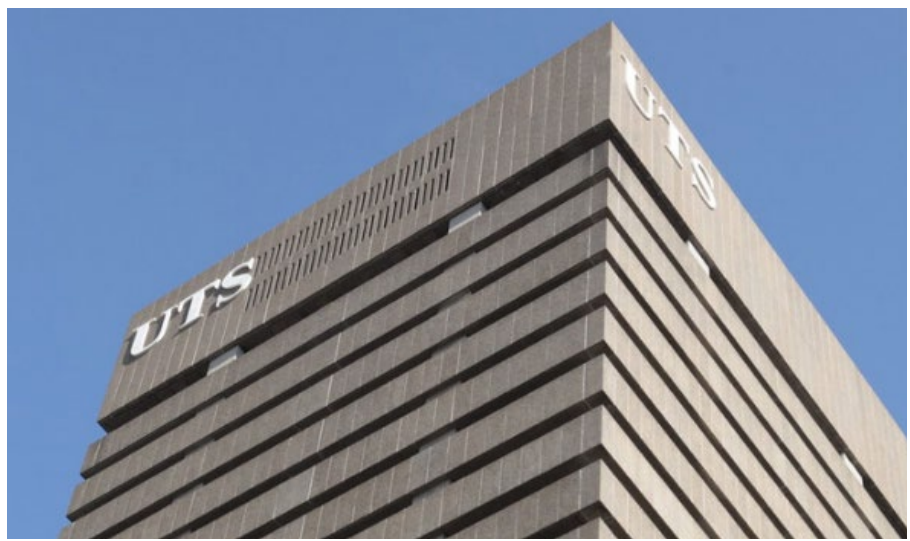

Questions were raised about the national security implications of the partnership between the University of Technology Sydney and China Electronics Technology Corporation Photo: Charlie Brewer, Flickr 
To date, there is no evidence that any Australian university has violated the laws and regulations put in place by the Australian government. Questioned about compliance in Senate estimates in late 2017, then secretary of defence, Greg Moriarty, replied that in his experience Australian universities 'are very conscious of the dangers and risks around these leakages of technology'. ${ }^{29}$

While universities may follow the rules, the existing DTCs are arguably inadequate for managing the risks in a changed national security environment. This view is reflected in the DTC review released in February 2019. It concludes that some gaps exist that need closing, such as 'inadequate control of emerging and sensitive military and dualuse technology'. However, the sweeping changes advocated by some in the defence and security community were deemed unnecessary. ${ }^{30}$

This is not to deny the existence of security and other risks for Australia in international scholarly collaboration and exchange, including with China. But there are also economic and even security benefits stemming from Australia's capacity to create knowledge and access cutting-edge technologies in a growing number of fields in which China now leads the world. Australia spends about US $\$ 25$ billion (AU\$36.4 billion) on research and development (R\&D) each year..$^{31}$ Both the United States and China spend about US $\$ 500$ billion. Last year, the R\&D budget of a single Chinese technology company, Huawei, was US $\$ 15.3$ billion, ${ }^{32}$ which is more than the total spent by all businesses in Australia. If Australia punches above its weight in research in science and engineering - fields that help drive long-term prosperity - this is in no small part due to international research collaboration, including with Chinese partners. As just one example, in 2017, of Australian articles in the top one percent of the AI articles most cited globally, 64.6 percent involved a collaborator in China. That is, only one-third of Australia's AI knowledge creation with the highest impact was produced without Chinese help. 
In June 2019, former secretary of the Australian Department of Defence Dennis Richardson observed that if the United States were to pursue a technological decoupling from China, and Australia followed suit, Australia would risk 'for the first time, us not having access to the best technology'. ${ }^{33}$ In August, UQ's Varghese told an audience assembled by the US Studies Centre at Sydney University that, realistically:

For Australia, there is no sensible alternative to engaging China ... the notion that global technology supply chains can be divided into a China-led system and a US-led system is both economic and geopolitical folly. ${ }^{34}$

\section{Concluding Thoughts}

In October 2019, the ABC's Four Corners program again turned its attention to Australian universities and their relationship with China, with a program titled 'Red Flags: The infiltration of Australia's universities by the Chinese Communist Party'. The reporter grilled UQ's Høj (as well as ANU Vice-Chancellor Brian Schmidt) about student activism on campus, cybersecurity, research collaboration, and links to the Chinese government. These issues, as we have seen, are complex and intertwined. But many of them are not nearly as sensational as portrayed in the media, nor does the commentary around them always do justice to the deeper structural changes in international education, research, and innovation. One thing is clear, however: as US-China competition intensifies, the Australian government and universities find themselves in increasingly difficult policy terrain. Navigating our way will require lucidity and focus on Australia's national interests and values - drawing clear red lines with respect to China on matters of academic freedom, for example, but also with the United States, which could pressure Australia into making decisions that threaten the university sector's ability for knowledge creation and collaboration with leading international partners. 
Australians are not the only ones learning to navigate their way. Just as the more contentious areas of joint research attract the most attention, so do the loudest and most aggressive students. Yet the majority of Chinese students (and scholars) studying and researching in Australian universities are simply pursuing their academic dreams and contributing positively to the intellectual and cultural vibrancy of campus life in the process. The right to (respectful) protest is one of several unfamiliar freedoms they must learn to navigate, with pressure coming from all directions, including from Chinese officials who expect them to toe the party line and vocal Australians who expect them not to. It is important to remember that their dreams are on the line as well. 


\section{NOTES}

\section{INTRODUCTION}

1 In the Yearbook, we use traditional characters when writing about classical texts and etymology, as well as Taiwan and Hong Kong (where they are used). Elsewhere we use simplified characters.

\section{FORUM - Illusions and Transformations: The Many Meanings of Meng 夢}

\section{From the Land of Illusion to the Paradise of Truth}

1 For more information on College Daily, see Jeremy Goldkorn, 'College Daily: Misleading Chinese students in the US since 2014', SupChina, 21 August 2019, online at: supchina.com/2019/08/21/ college-daily-misleading-chinese-students-in-the-u-s-since-2014

2 Han Zhang, 'The "post-truth" publication where Chinese students in America get their news', The New Yorker, 19 August 2019, online at: www.newyorker.com/culture/culture-desk/thepost-truth-publication-where-chinese-students-in-america-get-their-news

3 David Hawkes, The Golden Days: The Story of the Stone. Volume I, London: Penguin Books, 1973, p.130.

4 My translation.

5 John Minford, The Dreamer Wakes: The Story of the Stone. Volume V, London: Penguin Books, 1986, p.285.

\section{CHAPTER 1 - A Dream of Perpetual Rule}

1 Xi Jinping 习近平, 'A speech in celebration of the seventieth anniversary of the People's Republic of China'在庆祝中华人民共和国成立70周年大会上的讲话, Xinhua News, 1 October 2019, online at: www.xinhuanet.com/politics/2019-10/01/c 1125065799.htm

2 On party tifa, see Michael Schoenhals, 'Proscription and Prescription of Political Terminology by the Central Authorities, 1949-1989', in Chun-Chieh Huang and Erik Zürcher eds, Norms and the State in China, Leiden: E.J. Brill, 1993, pp.337-358.

3 Alexei Yurchak, Everything Was Forever, Until It Was No More: The Last Soviet Generation, Princeton, NJ: Princeton University Press, 2005, p.50. 
4 Ibid., p.293.

5 Xi's paraphrase of Gorbachev's remarks is inaccurate. For a summary of Gorbachev's speech at the 25 July 1991 plenary session of the Central Committee of the Communist Party of the Soviet Union, see Michael Parks, 'Gorbachev urges party to abandon Marxist ideology', Los Angeles Times, 26 July 1991, online at: www.latimes.com/archives/la-xpm-1991-07-26-mn-229-story. $\underline{\mathrm{html}}$

6 'Our revolutionary ideals are higher than heaven’ 革命理想高于天, Seeking Truth 求是, No.21, 1 November 2013, online at: www.qstheory.cn/zxdk/2013/201321/201310/t20131030 284176. $\underline{\mathrm{htm}}$

7 Geremie R. Barmé and Michael Szonyi, 'Chinese history in the era of the China Dream', in Michael Szonyi ed., A Companion to Chinese History, Chichester, UK: John Wiley \& Sons, 2017, p.68.

8 People's Daily 人民日报, 'Xi Jinping discusses the China Dream: Hard work can make dreams come true' 习近平纵论中国梦: 实干才能梦想成真, Xinhua Newspaper Network, 29 November 2019, online at: www.xhby.net/tuijian/201911/t20191129 6424690.shtml

9 Gil Hizi, 'Speaking the China Dream: Self-Realization and Nationalism in China's Public-Speaking Shows', Continuum, Vol.33, No.1 (2019): 37-50, at p.40.

${ }^{10}$ Comment by 'When you hear the wind it must be rain' 听风就是雨 on 'China Dream, My Dream' 中 国梦, 我的梦, Bilibili.com, 30 November 2017, online at: www.bilibili.com/video/av16796161/. The quotation is a meme from the mid 2010s.

${ }^{11}$ Comment by 'Idle and superfluous salty fish' 又闲又多余的威鱼, on 'China Dream, My Dream' 中国梦, 我的梦, Bilibili.com, 30 November 2017, online at: www.bilibili.com/video/av16796161/

12 Hizi, 'Speaking the China Dream', pp.43-44.

${ }^{13}$ Huanyanshe 幻研社, 'Has Marx crossed over into anime? The Leader shows you how to appreciate Marxism in cartoon form’ 马克思穿越二次元? 《领风者》带你领略动画里的马克思主义, Bilibili. com, 20 December 2018, online at: www.bilibili.com/read/cv1734554/

${ }^{14}$ Wan Jixuan 万雾营, Jiang Zhengxiang 蒋正翔, and Wu Congcong 吴丛丛, 'Reinvent and broadcast Marxism as widely as possible, bring Marx and “Generation Z” together' 创新马克思主义大众化 传播, 让马克思与“Z世代”相遇, Guangming Daily, 29 January 2019, online at: theory.gmw.cn/201901/29/content 32430697.htm

${ }^{15}$ Qian Zhecheng, 'Anime series on Karl Marx debuts to mixed reviews', Sixth Tone, 30 January 2019, online at: www.sixthtone.com/news/1003508/anime-series-on-karl-marx-debuts-tomixed-reviews

${ }^{16}$ Sixth Tone, 'About us', n.d., online at: www.sixthtone.com/about-us

${ }_{17}$ David Bandurski, 'Reading The Paper', [China Media Project], Medium, 7 July 2016, online at: medium.com/china-media-project/reading-the-paper-d15ec241652f

${ }^{18}$ Quoted in Wan et al., 'Reinvent and broadcast Marxism as widely as possible'.

${ }^{19}$ Xi Jinping, 'A speech in commemoration of the 100th anniversary of the May Fourth Movement' 在纪念五四运动100周年大会上的讲话, Xinhua, 30 April 2019, online at: www.xinhuanet.com/ politics/leaders/2019-04/30/c 1124440193.htm. All subsequent quotations from Xi's speech have been taken from this source.

${ }^{20}$ Yurchak, Everything Was Forever, Until It Was No More, p.1.

${ }^{21}$ Lu Xun, Selected Works. Volume 1, Translated by Yang Xianyi and Gladys Yang, Beijing: Foreign Languages Press, 1980, p.37. 


\section{FORUM - Enforcing the Dream}

\section{Xi Jinping's War on 'Black and Evil'}

1 China News Network, 'Anti-Crime Office: As of the end of March, 14,226 criminal and black crime cases were prosecuted nationwide', Xinhua, 9 April 2019, online at: www.xinhuanet. com/2019-04/09/c 1124343704.htm

2 Ben Hillman, Patronage and Power: Local State Networks and Party-state Resilience in Rural China, Stanford, CA: Stanford University Press, 2014.

3 Since dynastic times, Chinese rulers have rotated local officials between areas to prevent them from becoming personally connected to local elite networks and forming their own local power bases. The Chinese Communist Party continues this practice to the present day. For more on this, see Ben Hillman, 'Factions and Spoils: Examining Political Behavior within the Local State in China', The China Journal, no.64 (2010): 1-18.

4 'Observation of the operational trajectory of several "evil umbrellas" in Liaoning', Xinhua, 21 May 2019, online at: www.xinhuanet.com/legal/2019-05/21/c 1124523669.htm

5 Legal Daily, 'Nanjing fights against evil to solve social governance problems', Xinhua, 6 June 2019, online at: www.xinhuanet.com/2019-06/06/c 1124588670.htm.

6 On Chinese state media's portrayal of the Hong Kong protests, see Ben Hillman, 'Hong Kong protests in the mainland eye', East Asia Forum, 21 October 2019. On Chinese Communist Party characterisations of the Tibetan protests of 2008-2009 and Uyghur protests of 2009, see Ben Hillman and Gray Tuttle eds, Ethnic Conflict and Protest in Tibet and Xinjiang: Unrest in China's West, New York: Columbia University Press, 2016.

7 Shanghai Municipality's Special Campaign to Fight Crime and Eradicate Evil, Shanghai: Shanghai Municipal People's Government, 24 January 2018, online at: www.shanghai.gov.cn/nw2/ nw2314/nw44975/nw44976/nw44977/u21aw1385755.html

\section{The Changing 'Dream' in the Classroom: Literary Chinese Textbooks in the PRC}

1 The Secondary School Language Section of the People's Education Press 人民教育出版社中學語 文室 eds, Key Instructions on Teaching with Our Language Textbooks for Secondary School 中學 語文課本教學重點說明, Beijing: People’s Education Press, 1984, p.79.

2 Chen Xubin 谌旭柊, “The new language and literature textbooks have excised the chapter on Chen She' 新版语文教科书删掉了课文《陈涉世家》, China Digital Times, 21 February 2019, online at: chinadigitaltimes.net/chinese/2019/02/

3 Ling Yun, 'The removal of Che She Family from junior high school Chinese language curriculum led to heated discussion' 中國初中語文删除《陳涉世家》引熱議, DW News, 25 February 2019, online at: news.dwnews.com/china/big5/news/2019-02-25/60120251.html

4 'Chinese language and literature teaching materials remove the Chen She/Wu Guang uprising: Curricular adjustment or political strategy?' 中国语文教材删陈胜吴广起义学术考量还是政治意图?, BBC News, [Chinese edition], 27 February 2019, online at: www.bbc.com/zhongwen/simp/chinese-news-47369438

5 Robert Weatherley and Coirle Magee, 'Using the Past to Legitimise the Present: The Portrayal of Good Governance in Chinese History Textbooks', Journal of Current Chinese Affairs, vol.47, no.1 (2018): 41-69, at p.48. 
6 Ministry of Education, 'The person in charge of the Teaching Material Bureau of the Ministry of Education answers reporters' questions on the compilation of three compulsory education textbooks' 教育部教材局负责人就义务教育三科教材统编工作答记者问, Beijing: Ministry of Education of the PRC, 28 August 2019, online at: www.moe.gov.cn/jyb xwfb/s271/201708/ t20170828 312487.html

\section{CHAPTER 2 - Hong Kong's Reckoning}

1 Brian C.H. Fong, 'Stateless Nation Within a Nationless State: The Political Past, Present, and Future of Hong Kongers, 1949-2019', Nations and Nationalism, 16 August 2019: 1-18, doi. org/10.1111/nana.12556

2 Richard McGregor, Xi Jinping: The Backlash, Sydney: Random House Australia, 2019.

3 These numbers are approximate as not all candidates explicitly declared a political affiliation. Some media outlets credited slightly more seats to the pan-democrats, while some credited slightly more to independent candidates.

\section{FORUM — Under Observation}

\section{Legalism and the Social Credit System}

1 Rogier Creemers, 'China’s Social Credit System: An evolving practice of control', 9 May 2018, pp.8-9, online at: papers.ssrn.com/sol3/papers.cfm?abstract id $=3175792$

2 Han Fei, Han Feizi: Basic Writings, New York: Columbia University Press, 2003, p.28.

3 Shang Yang, The Book of Lord Shang: Apologetics of State Power in Early China, New York: Columbia University Press, 2017, p.210.

4 Han Fei, Han Feizi, p.36.

5 Zhengyuan Fu, China's Legalists: The Earliest Totalitarians and Their Art of Ruling, Armonk, NY: M.E. Sharpe, 1996, pp.40-41.

6 State Council of the People's Republic of China, Planning Outline for the Construction of a Social Credit System (2014-2020), Beijing: State Council, 14 June 2014.

7 Martin Chorzempa, Paul Triolo, and Samm Sacks, 'China's Social Credit System: A mark of progress or a threat to privacy?', Policy Brief No. PB18-14, Washington, DC: Peterson Institute for International Economics, 2018, pp.1-2.

8 State Council of the People's Republic of China, Some Opinions Concerning the Construction of a Social Credit System, Beijing: State Council General Office, 23 March 2007 [Last modified 26 March 2016].

9 Delia Lin, 'The CCP's exploitation of Confucianism and legalism', in Routledge Handbook of the Chinese Communist Party. Volume 1, London: Taylor \& Francis, 2017, p.48; Xi Jinping, The Governance of China, Beijing: Foreign Languages Press, 2014, pp.434, 457; and Xi Jinping, The Governance of China. Volume 2, Beijing: Foreign Languages Press, 2018, pp.152, 322, 324.

${ }^{10}$ Genia Kostka, 'China's Social Credit Systems and Public Opinion: Explaining High Levels of Approval', New Media \& Society, vol.21, no.7 (2019): 1573. 


\section{'Evil Cults' and Holy Writ}

1 'US urged to stop interfering in China's internal affairs under pretext of religion', China Daily, 19 July 2019, online at: www.chinadaily.com.cn/a/201907/19/WS5d309e13a310d830563ffccb. html

2 Massimo Introvigne, “"Cruel Killing, Brutal Killing, Kill the Beast”: Investigating the 2014 McDonald's “Cult Murder” in Zhaoyuan', The Journal of CESNUR, vol.1, no.1 (September-October 2017): 61-73.

3 Emily Dunn, Lightning from the East: Heterodoxy and Christianity in Contemporary China, Leiden: Brill, 2015.

4 This policy was initiated by Xi at the April 2016 National Working Meeting on Religions. See 'Xi Jinping: Comprehensively improve the level of religious work in the New Era' 习近平: 全面提高新形势下宗教工作水平, Xinhua, 23 April 2016, online at: www.xinhuanet.com/politics/2016-04/23/c 1118716540.htm

5 Yi Ming, 'Hebei Province Holds a High-level Seminar on “Daoism Stresses Sinicization”, 河北省 举办道教坚持中国化方向高级研讨班, quoted in Benoit Vermander, 'Sinicizing Religion, Sinicizing Religious Studies', Religions, vol.10, no.137 (2019): 1-23, at p.4. These sentiments are found consistently in statements from religious leaders and commentators.

\section{CHAPTER 3 - Meridians of Influence in a Nervous World}

1 Hedley Bull, The Anarchical Society: A Study of Order in World Politics, 3rd edn, New York: Palgrave, 2002, p.212.

2 Cited in Henry Kissinger, Diplomacy, New York: Simon \& Schuster, 1994, pp.35-36.

3 Bull, The Anarchical Society, p.212.

4 For further reading on the history of spheres of influence, see Susanna Hast, Spheres of Influence in International Relations: History, Theory and Politics, Abingdon, UK: Routledge, 2016.

5 Paul Keal, 'Contemporary Understanding about Spheres of Influence', Review of International Studies, vol.9, no.3 (July 1983): 155-172, at p.156.

6 Cited in Iain Ferguson and Susanna Hast, 'Introduction: The Return of Spheres of Influence?', Geopolitics, vol.23, no.2 (2018): p.277-284, at p.277.

7 National Security Strategy of the United States of America, Washington, DC: The White House, December 2017, p.25.

8 Robert Ross, 'The Geography of the Peace: East Asia in the Twenty-First Century', International Security, vol.23, no.4 (Spring 1999): 81-118, at p.99.

9 Denny Roy, 'Assertive China: Irredentism or Expansionism?', Survival, vol.61, no.1 (FebruaryMarch 2019): 51-74, at p.63.

${ }^{10}$ Hugh White, 'Without America: Australia in the New Asia', Quarterly Essay, no.68 (2017): 61.

${ }^{11}$ Van Jackson, 'Asian security after US hegemony: Spheres of influence and the third wave of regional order', The Asan Forum, 14 October 2016, online at: www.theasanforum.org/asiansecurity-after-us-hegemony-spheres-of-influence-and-the-third-wave-of-regional-order/

12 Nadège Rolland, 'A China-Russia Condominium over Eurasia', Survival, vol.61, no.1 (FebruaryMarch 2019): 7-22, at p.8. 
${ }_{13}$ Paul Dibb, 'Why we need a radically new defence policy', The Strategist, 29 September 2019, online at: www.aspistrategist.org.au/why-we-need-a-radically-new-defence-policy/

${ }^{14}$ Hugh White, 'In Denial: Defending Australia as China Looks South', Australian Foreign Affairs, no.6 (July 2019), p.20.

${ }^{15}$ Ben Blanchard, 'China not seeking "sphere of influence” in Pacific, Xi says', Reuters, 29 May 2019, online at: www.reuters.com/article/us-china-vanuatu-idUSKCN1SZ02N

${ }^{16}$ General Wei Fenghe, 'Speech at the 18th Shangri-La Dialogue by Gen. Wei Fenghe State Councilor and Minister of National Defense, PRC', Singapore, 2 June 2019, online at: www.iiss.org/ events/shangri-la-dialogue/shangri-la-dialogue-2019

17 David C. Kang, 'Getting Asia Wrong: The Need for New Analytical Frameworks', International Security, vol.27, no.4 (Spring 2003): 57-85, at p.58.

${ }^{18}$ For further reading, see Richard Rigby, 'Tianxia', in Geremie R. Barme and Jeremy Goldkorn eds, China Story Yearbook 2013: Civilising China, Canberra: Australian Centre on China in the World, 2013, pp.74-79. A detailed and up-to-date account of discussion of this issue by PRC scholars in recent years is to be found in Liang Zhiping, 'Tianxia and ideology', [in 2 parts], Introduction and Translation by David Ownby, Reading the China Dream, 2018, online at: www.readingthechinadream.com/liang-zhiping-tianxia-and-ideology.html

${ }^{19}$ For further reading, see David C. Kang, East Asia Before the West, New York: Columbia University Press, 2010, pp.54-81.

${ }^{20}$ Wang Yi, Work Together to Create a Community of Shared Future for Mankind, Beijing: Ministry of Foreign Affairs of the People's Republic of China, 31 May 2016, online at: www.fmprc.gov. $\mathrm{cn} / \mathrm{mfa}$ eng/zxxx 662805/t1369269.shtml

${ }^{21}$ Laura Silver, Kat Devlin, and Christine Huang, 'People around the globe are divided in their opinions of China', Fact Tank: News in the Numbers, Washington, DC: Pew Research Center, 5 December 2019, online at: www.pewresearch.org/fact-tank/2019/12/05/people-around-theglobe-are-divided-in-their-opinions-of-china/

${ }^{22}$ Natasha Kassam, Lowy Institute Poll 2019: Understanding Australian Attitudes to the World, Sydney: Lowy Institute, 2019, p.8.

${ }^{23}$ For further reading, see 'Aircraft-carriers are big, expensive, vulnerable - and popular', The Economist, 14 November 2019, online at: www.economist.com/briefing/2019/11/14/aircraft-carriers-are-big-expensive-vulnerable-and-popular

${ }^{24}$ Rory Medcalf, 'The many questions about China's Vanuatu ambition', The Interpreter, 10 April 2018, online at: www.lowyinstitute.org/the-interpreter/many-questions-about-china-s-vanuatu-ambition

${ }^{25}$ Denghua Zhang, 'China's Diplomacy in the Pacific: Interests, Means and Implications', Security Challenges, vol.13, no.2 (2017): 32-53, at p.42.

${ }^{26}$ Daniel Victor, 'Dream Works film “Abominable” is pulled by Vietnam over Chinese map scene', The New York Times, 15 October 2019, online at: www.nytimes.com/2019/10/15/world/asia/ abominable-vietnam-china-map.html

${ }^{27}$ Edward Cavanough, 'China and Taiwan offered us huge bribes, say Solomon Islands MPs', The Guardian, 8 December 2019, online at: www.theguardian.com/world/2019/dec/08/china-andtaiwan-offered-us-huge-bribes-say-solomon-islands-mps 


\section{FORUM - Projecting the Dream}

\section{Dreams in Space}

1 Steven Lee Myers and Zoe Mou, "New chapter" in space exploration as China reaches far side of the Moon', The New York Times, 2 January 2019, online at: www.nytimes.com/2019/01/02/ world/asia/china-change-4-moon.html

2 State Council of the People's Republic of China, 'China's space activities in 2016', White Paper, Beijing: State Council Information Office, 27 December 2016, online at: english.www.gov.cn/ archive/white paper/2016/12/28/content 281475527159496.htm

3 'Backgrounder: Xi Jinping's vision for China's space development', Xinhua, 24 April 2017, online at: www.xinhuanet.com/english/2017-04/24/c 136232642.htm

4 Andrew Jones, 'China continues intense activity with environment, navigation satellite launches', SpaceNews, 25 September 2019, online at: spacenews.com/china-continues-intense-activity-with-environment-navigation-satellite-launches/

5 'Orbital launches of 2019', Gunter's Space Page, 2 December 2019, online at: space.skyrocket. de/doc chr/lau2019.htm

6 'China prepares for space station construction', Xinhua, 17 October 2019, online at: www.xinhuanet.com/english/2019-10/17/c 138479514.htm

7 'China to launch Chang'e-5 lunar probe in 2020', Xinhua, 26 October 2019, online at: www. xinhuanet.com/english/2019-10/26/c 138505684.htm; and 'China drawing up plan for manned lunar exploration', Xinhua, 28 October 2019, online at: www.xinhuanet.com/english/2019-10/28/c 138509382.htm

8 'Chinese deep space research leads to deeper international cooperation', Xinhua, 7 May 2019, online at: www.xinhuanet.com/english/2019-05/07/c 138040362.htm

9 'Xinhua headlines: China's commercial space industry takes off with successful orbital launch', Xinhua, 25 July 2019, online at: www.xinhuanet.com/english/2019-07/25/c 138258019.htm

${ }_{10}$ Ibid.

${ }^{11}$ State Council, 'China's space activities in 2016'.

${ }^{12}$ Mitsuru Obe, 'NASA chief hits at China's "aggressive” space activity', Nikkei Asian Review, 24 September 2019, online at: asia.nikkei.com/Editor-s-Picks/Interview/NASA-chief-hits-at-China-s-aggressive-space-activity

13 'China strengthens international space cooperation', Xinhua, 19 April 2018, online at: www. xinhuanet.com/english/2018-04/19/c 137123117.htm

${ }^{14}$ State Council of the People's Republic of China, China's National Defence in the New Era, Beijing: State Council, 24 July 2019, online at: english.www.gov.cn/archive/whitepaper/201907/24/ content WS5d3941ddc6d08408f502283d.html

15 See Adam Ni and Bates Gill, 'The People's Liberation Army Strategic Support Force: Update 2019', China Brief, vol.19, no.10 (29 May 2019), online at: jamestown.org/program/the-peoples-liberation-army-strategic-support-force-update-2019/

${ }^{16}$ See Zhoubi Song, 'New requirements for military capabilities', Military Reporter, 15 August 2016, online at: zlzy.81.cn/tb/2016-08/15/content_7231775.htm 
${ }_{17}$ Paul K. Byrne, 'Mining the Moon', The Conversation, 5 March 2019, online at: theconversation. com/mining-the-moon-110744

18 Matthew Walsh, 'China will create ‘space economic zone' by midcentury: Report', Caixin Global, 1 November 2019, online at: www.caixinglobal.com/2019-11-01/china-will-create-space-economic-zone-by-midcentury-report-101477919.html

19 'Hot-blooded academician Ye Peijian: Looking to the future, exploring the sea of stars', CCTV, 18 September 2019, online at: news.cctv.com/2019/09/18/ARTI40ad9pLx5jBrz8rnohTS190918. shtml

${ }^{20}$ See, for example, Greg Autry and Steve Kwast, 'America is losing the second space race to China', Foreign Policy, 22 August 2019, online at: foreignpolicy.com/2019/08/22/america-is-losing-thesecond-space-race-to-chinal

${ }^{21}$ Mike Pence, 'Remarks by Vice President Pence at the Fifth Meeting of the National Space Council, Hunstville, AL', Washington, DC: The White House, 26 March 2019, online at: www. whitehouse.gov/briefings-statements/remarks-vice-president-pence-fifth-meeting-national-space-council-huntsville-al/

${ }^{22}$ Obe, 'NASA chief hits at China's "aggressive” space activity'.

${ }^{23}$ Mao Zedong, 'Reascending Chingkangshan', in Selected Works of Mao Tse-tung, Maoist Documentation Project, 2007 [1935], online at: www.marxists.org/reference/archive/mao/selected-works/poems/poems35.htm

\section{Antarctic Ambitions: Cold Power}

1 Jackson Gothe-Snape, 'Australia declares China's plan for Antarctic conduct has "no formal standing”', $A B C$ News, 30 July 2019, online at: www.abc.net.au/news/2019-07-30/antarctica-china-code-of-conduct-dome-a/11318646

2 Anne-Marie Brady, China as a Polar Great Power, Cambridge: Cambridge University Press, 2017.

3 Peter FitzSimons, Mawson and the Ice Men of the Heroic Age: Scott, Shackleton and Amundsen, Sydney: William Heinemann, 2011.

4 Brady, China as a Polar Great Power.

5 Ibid.

6 Commonwealth of Australia, Australian Antarctic Strategy and 20 Year Action Plan, Canberra: Australian Government, 2016, online at: www.antarctica.gov.au/ data/assets/pdf file/0008/180827/20YearStrategy final.pdf; Nengye Liu, 'Why Antarctica depends on Australia and China's alliance', The Conversation, 8 July 2019, online at: theconversation.com/why-antarctica-depends-on-australia-and-chinas-alliance-59522

7 Brady, China as a Polar Great Power.

8 Ibid, p.50.

9 Ibid.

${ }^{10}$ Ibid.

11 Ibid., p.36.

${ }^{12}$ Jeffrey McGee and Marcus Haward, 'Australia-China relations in the frozen south', Australian Outlook, Canberra: Australian Institute of International Affairs, 28 February 2019, online at: www.internationalaffairs.org.au/australianoutlook/australia-china-antarctica/

13 Elizabeth Buchanan, 'Antarctica: A cold, hard reality check', The Strategist, 17 September 2019, online at: www.aspistrategist.org.au/antarctica-a-cold-hard-reality-check/ 
${ }^{14}$ Jackson Gothe-Snape, 'China unchecked in Antarctica', ABC News, 30 March 2019 [Updated 12 April 2019], online at: www.abc.net.au/news/2019-03-30/china-in-antarctica-inspection-regime/10858486

${ }^{15}$ Brady, China as a Polar Great Power.

${ }^{16}$ Nengye Liu, 'What are China's intentions in Antarctica?', The Diplomat, 14 June 2019, online at: thediplomat.com/2019/06/what-are-chinas-intentions-in-antarctica/

${ }^{17}$ Ibid.

18 Commonwealth of Australia, Australian Antarctic Strategy.

19 Ibid.

\section{CHAPTER 4 - Conscious Decoupling: The Technology Security Dilemma}

1 Geoffrey Gertz, 'Trump can’t decide what he wants from China', Foreign Policy, 11 September 2019, online at: foreignpolicy.com/2019/09/11/trump-cant-decide-what-he-wants-fromchina/. Also see Jonathan D. Pollack and Jeffrey A. Bader, 'Looking before we leap: Weighing the risks of US-China disengagement', Policy Brief, Washington, DC: The Brookings Institution, July 2019, online at: www.brookings.edu/wpikenberry-content/uploads/2019/07/FP 20190716 us china pollack bader.pdf

2 In September 2019, Foreign Minister Wang Yi described decoupling as 'just like an attempt to build castles in the air. It is neither sensible nor realistic. Decoupling from the Chinese economy would be decoupling from opportunities, and from the future.' Wang Yi, 'Decoupling from the Chinese economy would be decoupling from opportunities and from the future', Embassy of the People's Republic of China in The Federal Democratic Republic of Nepal, Kathmandu, 25 September 2019, online at: www.fmprc.gov.cn/ce/cenp/eng/zgwj/t1701345.htm

3 Orange Wang, 'Chinese economists warn Beijing to prepare for decoupling from US', South China Morning Post, 7 July 2019, online at: www.scmp.com/news/china/article/3017550/chinese-economists-warn-beijing-prepare-decoupling-us

4 Charissa Yong, 'Decoupling of US, Chinese economies likely inevitable', Straits Times, 16 June 2019, online at: www.straitstimes.com/world/united-states/decoupling-of-us-chinese-economies-likely-inevitable. For an example of a decoupling 'advocate', see: Nicholas Phillips, 'The trade war is smart geopolitics', National Review, 5 September 2019, online at: www.nationalreview.com/2019/09/us-china-trade-war-smart-geopolitics/

5 Dewey Sim, 'US and China set on "decoupling” amid their clash of civilisations, Singapore Forbes forum told', South China Morning Post, 15 October 2019, online at: www.scmp.com/week-asia/ economics/article/3033054/us-and-china-set-decoupling-amid-their-clash-civilisations

6 National Security Strategy of the United States of America, Washington, DC: The White House, December 2017, online at: www.whitehouse.gov/wp-content/uploads/2017/12/NSS-Final-12-18-2017-0905.pdf; Anthea Roberts, Henrique Choer Moraes, and Victor Ferguson, 'Geoeconomics: The US strategy of technological protection and economic security', Lawfare, 11 December 2018, online at: www.lawfareblog.com/geoeconomics-us-strategy-technological-protection-and-economic-security

7 Michael Mastanduno, Economic Containment: CoCom and the Politics of East-West Trade, Ithaca, NY: Cornell University Press, 1992.

8 Similar ideas were prominent in Washington during the 1980s trade tensions with Tokyo. Unlike China, however, Japan was a US security ally. On the similarities and differences between the two trade disputes, see John Hemmings and James Amedeo, 'Lessons from the America-Japan 
trade war of the 1980s', The National Interest, 2 July 2018, online at: nationalinterest.org/feature/lessons-america-japan-trade-war-1980s-24882

9 See Anthea Roberts, Henrique Choer Moraes, and Victor Ferguson, 'The US-China trade war is a competition for technological leadership', Lawfare, 21 May 2019, online at: www.lawfareblog. com/us-china-trade-war-competition-technological-leadership

10 Andrew Grotto and Martin Schallbruch, 'The great anti-China tech alliance: The United States and Europe will regret letting Beijing win the race to govern digital technology', Foreign Policy, 16 September 2019, online at: foreignpolicy.com/2019/09/16/the-west-will-regret-letting-china-win-the-tech-race/; David Shambaugh, 'The new American bipartisan consensus on China policy', China-US Focus, 21 September 2018, online at: www.chinausfocus.com/foreign-policy/ the-new-american-bipartisan-consensus-on-china-policy. Although note the open letter from 100 academics, foreign policy experts, and business leaders in the United States warning against decoupling: M. Taylor Fravel, J. Stapleton Roy, Michael D. Swaine, Susan A. Thornton, and Ezra Vogel, 'China is not an enemy', The Washington Post, 3 July 2019, online at: www.washingtonpost.com/opinions/making-china-a-us-enemy-is-counterproductive/2019/07/02/647d49d09bfa-11e9-b27f-ed2942f73d70 story.html

${ }^{11}$ Adam Segal, 'Seizing core technologies: China responds to US technology competition', China Leadership Monitor, 1 June 2019, online at: www.prcleader.org/segal-clm-60; Minghao Zhao, 'Is a New Cold War Inevitable? Chinese Perspectives on US-China Strategic Competition, The Chinese Journal of International Politics, vol.12, no.3 (Autumn 2019): 371-394, online at: academic. oup.com/cjip/article/12/3/371/5544745

12 Kevin Rudd, 'The trade war, economic decoupling and future Chinese strategy towards America', Remarks prepared for Lowy Institute event, Sydney, 13 June 2019, online at: www. lowyinstitute.org/publications/trade-war-economic-decoupling-and-future-chinese-strategy-towards-america

${ }^{13}$ Darren J. Lim and G. John Ikenberry, 'China and the Logic of Illiberal Hegemony’, Working Paper, The Australian National University and Princeton University (October 2019).

${ }^{14}$ Ehizuelen Michael and Mitchell Omoruyi, 'China's march towards a moderately well-off society', China Daily, 16 March 2018, online at: www.chinadaily.com.cn/a/201803/16/WS5aab21d6a3106e7dcc142020.html

15 See Andrew B. Kennedy and Darren J. Lim, 'The Innovation Imperative: Technology and US-China Rivalry in the Twenty-First Century', International Affairs, vol.94, no.3 (May 2018): 553-572, online at: academic.oup.com/ia/article/94/3/553/4992406; Anthea Roberts, Henrique Choer Moraes, and Victor Ferguson, 'Geoeconomics: The Chinese strategy of technological advancement and cybersecurity', Lawfare, 3 December 2018, online at: www.lawfareblog. com/geoeconomics-chinese-strategy-technological-advancement-and-cybersecurity; Paul Hubbard and Dhruv Sharma, 'Understanding and applying long-term GDP projections', EABER Working Paper 119, Canberra: The East Asian Bureau of Economic Research, The Australian National University, 2 June 2016, online at: www.eaber.org/node/25601

${ }^{16}$ Darren J. Lim, 'The US, China and “technology war”', Global Asia, 27 March 2019, online at: www.globalasia.org/v14no1/cover/the-us-china-and-technology-war darren-lim

${ }_{17}$ Robert Jervis, 'Cooperation Under the Security Dilemma', World Politics, vol.30, no.2 (1978): 167-214.

${ }^{18}$ Kenneth Waltz, Theory of International Politics, Reading, MA: Addison-Wesley, 1979.

19 Aruna Viswanatha, Eva Dou, and Kate O’Keeffe, 'ZTE to pay \$892 million to US, plead guilty in Iran sanctions probe', The Wall Street Journal, 7 March 2017, online at: www.wsj.com/articles/ zte-to-pay-892-million-to-u-s-plead-guilty-in-iran-sanctions-probe-1488902019 
${ }^{20}$ Joy Dantong Ma, 'Chip on the shoulder: How China aims to compete in semiconductors', MacroPolo, 10 September 2019, online at: macropolo.org/china-chips-semiconductors-artificial-intelligence/

${ }^{21}$ James Andrew Lewis, China's Pursuit of Semiconductor Independence, Washington, DC: Center for Strategic and International Studies, 27 February 2019, online at: www.csis.org/analysis/ chinas-pursuit-semiconductor-independence

${ }^{22}$ Jodi Xu Klein, 'Donald Trump gets his way as US lifts ZTE ban, allowing company to continue despite senators' opposition', South China Morning Post, 14 July 2018, online at: www.scmp. com/news/china/economy/article/2155238/us-lifts-ban-american-companies-selling-partschinas-zte

${ }^{23}$ 'China chipmaker accused of IP theft looks to rival for rescue', Financial Times, 9 May 2019, online at: www.ft.com/content/94eeb7f8-7232-11e9-bf5c-6eeb837566c5

${ }^{24}$ Jeanne Whalen, 'Next few months may show if Huawei can thrive without US tech sales', The Washington Post, 8 October 2019, online at: www.washingtonpost.com/business/2019/10/07/ next-few-months-may-show-if-huawei-can-survive-thrive-despite-us-ban-sales/

${ }^{35}$ Roberts et al., 'The US-China trade war is a competition for technological leadership'.

${ }^{26}$ Jost Wübbeke, Mirjam Meissner, Max J. Zenglein, Jaqueline Ives, and Björn Conrad, 'Made in China 2025: The making of a high-tech superpower and consequences for industrial countries', MERICS Papers on China No. 2, Berlin: Mercator Institute for China Studies, December 2016, online at: www.merics.org/sites/default/files/2017-09/MPOC No.2 MadeinChina2025.pdf

${ }^{27}$ Lindsay Maizland and Andrew Chatzky, 'Huawei:China's controversial tech giant’,Backgrounder, New York: Council on Foreign Relations, 12 June 2019, online at: www.cfr.org/backgrounder/ huawei-chinas-controversial-tech-giant; Keith Johnson and Elias Groll, 'The improbable rise of Huawei', Foreign Policy, 3 April 2019, online at: foreignpolicy.com/2019/04/03/the-improbable-rise-of-huawei-5g-global-network-china/

${ }^{28}$ State influence can occur formally through party committees set up in firms or through broader political guidance and the cooption of business elites. See Colin Hawes and Grace Li, 'Transparency and opaqueness in the Chinese ICT sector: A critique of Chinese and international corporate governance norms', Asian Journal of Comparative Law, 27 July 2016, online at: www. ssrn.com/abstract $=2814781$

${ }^{29}$ See, for example, Christopher Balding and Donald C. Clarke, Who Owns Huawei?, 17 April 2019, online at: www.ssrn.com/abstract=3372669; Ashley Feng, 'We can't tell if Chinese firms work for the Party', Foreign Policy, 7 February 2019, online at: foreignpolicy.com/2019/02/07/ we-cant-tell-if-chinese-firms-work-for-the-party/; Finbarr Bermingham, 'Australia's Huawei $5 \mathrm{G}$ ban is a "hedge" against future Chinese aggression, says former prime minister Malcolm Turnbull', South China Morning Post, 29 March 2019, online at: www.scmp.com/economy/china-economy/article/3003715/australias-huawei-5g-ban-hedge-against-future-chinese

30 See, for example, 'The US is seeking to constrain China's rise', Financial Times, 20 May 2019, online at: www.ft.com/content/6bd052b2-7aef-11e9-81d2-f785092ab560

${ }^{31}$ Max J. Zenglein and Anna Holzmann, 'Evolving Made in China 2025: China's industrial policy in the quest for global tech leadership', MERICS Papers on China No. 8, Berlin: Mercator Institute for China Studies, July 2019, online at: www.merics.org/en/papers-on-china/evolving-madein-china-2025

${ }^{32}$ Sarah Dai, “China adds Huawei, Hikvision to expanded "national team” spearheading country's AI efforts', South China Morning Post, 30 August 2019, online at: www.scmp.com/tech/big-tech/ article/3024966/china-adds-huawei-hikvision-expanded-national-team-spearheading 
${ }^{33}$ Jeffrey W. Knopf, 'Varieties of Assurance’, Journal of Strategic Studies, vol.35, no.3 (2012): 375399, doi.org/10.1080/01402390.2011.643567

${ }^{34}$ Lewis, China's Pursuit of Semiconductor Independence.

${ }^{35}$ Gregory C. Allen, 'Understanding China's AI strategy: Clues to Chinese strategic thinking on artificial intelligence and national security', White Paper, Washington, DC: Center for a New American Security, 6 February 2019, online at: www.cnas.org/publications/reports/understanding-chinas-ai-strategy

${ }^{36}$ G. John Ikenberry, After Victory: Institutions, Strategic Restraint, and the Rebuilding of Order after Major Wars, Princeton, NJ: Princeton University Press, 2001.

${ }^{37}$ See Christopher Ashley Ford, 'Huawei and its siblings, the Chinese tech giants: National security and foreign policy implications', Remarks by Dr Christopher Ashley Ford, Assistant Secretary, Bureau of International Security and Nonproliferation, Multilateral Action on Sensitive Technologies (MAST) Conference, Loy Henderson Auditorium, US Department of State, Washington, DC, 11 September 2019, online at: www.state.gov/huawei-and-its-siblings-the-chinese-tech-giants-national-security-and-foreign-policy-implications/; Agence France-Presse, 'Too much risk in Huawei's ties to Chinese government, US defence chief says', South China Morning Post, 1 June 2019, online at: www.scmp.com/news/china/diplomacy/article/3012714/too-muchrisk-huaweis-ties-chinese-government-us-defence-chief

${ }^{38}$ Danielle Cave, 'Australia and the great Huawei debate: Risks, transparency and trust', The Strategist: The Australian Strategic Policy Institute Blog, 11 September 2019, online at: www.aspistrategist.org.au/australia-and-the-great-huawei-debate-risks-transparency-and-trust/

39 'Ren Zhengfei may sell Huawei's 5G technology to a Western buyer', The Economist, 12 September 2019, online at: www.economist.com/business/2019/09/12/ren-zhengfei-may-sell-huaweis-5g-technology-to-a-western-buyer

${ }^{40}$ Charles Rollet, 'Huawei ban means the end of global tech: As the United States and China square off, firms will be forced to decouple', Foreign Policy, 17 May 2019, online at: foreignpolicy. com/2019/05/17/huawei-ban-means-the-end-of-global-tech/

${ }^{41}$ See Darren J. Lim and Victor Ferguson, 'Huawei and the decoupling dilemma', The Interpreter, 28 May 2019, online at: www.lowyinstitute.org/the-interpreter/huawei-and-decoupling-dilemma

42 Dan Primack and Courtenay Brown, 'US companies aren't leaving China for America, despite what Trump says', Axios, 30 August 2019, online at: www.axios.com/us-companies-arent-leaving-china-for-america-despite-what-trump-says-bf443362-03fd-4292-ba79-223fc79fe2b2.

html. But compare this with: Nicholas Lardy, 'Foreign firms in China resist Trump's trade war', East Asia Forum, 1 October 2019, online at: www.eastasiaforum.org/2019/10/01/foreignfirms-in-china-resist-trumps-trade-war/

${ }^{43}$ Thomas Wright, 'Sifting through Interdependence', The Washington Quarterly, vol.36, no.4 (2013): 7-23, doi.org/10.1080/0163660X.2013.861706, online at: www.tandfonline.com/doi/ abs/10.1080/0163660X.2013.861706

${ }^{44}$ On critical technologies, see Roberts et al., 'Geoeconomics: The US strategy of technological protection and economic security'.

${ }^{45}$ For a nuanced discussion of the microfoundations of disengagement in different areas of the bilateral economic relationship, see Gertz, 'Trump can't decide what he wants from China'.

${ }^{46}$ James Andrew Lewis, Emerging Technologies and Managing the Risk of Tech Transfer to China, Washington, DC: Center for Strategic and International Studies, 4 September 2019, online at: www.csis.org/analysis/emerging-technologies-and-managing-risk-tech-transfer-china 
${ }^{47}$ Henrique Choer Moraes, 'The turn to managed interdependence: A glimpse into the future of international economic law?', EJIL: Talk! Blog of the European Journal of International Law, 14 August 2018, online at: www.ejiltalk.org/the-turn-to-managed-interdependence-a-glimpse-into-the-future-of-international-economic-law/

\section{FORUM — Conscious Coupling!}

\section{Queer Dreams}

1 See Chris Lau, 'Victory for Hong Kong's LGBT community as High Court abolishes four offences that criminalise sex between men', South China Morning Post, 30 May 2019, online at: www. scmp.com/news/hong-kong/law-and-crime/article/3012509/victory-hong-kongs-lgbt-community-high-court-abolishes. Nevertheless, on 18 October 2019, a Hong Kong court banned a same-sex union petition made for two female Hong Kong permanent residents. See Tiffany May and Gerry Mullany, 'Hong Kong court rules against same-sex unions', The New York Times, 18 October 2019, online at: www.nytimes.com/2019/10/18/world/asia/hong-kong-same-sexunions.html

2 Viola Sarnelli, 'CCTV News and China's cultural policy presented to a global audience', in Paola Voci and Luo Hui eds, Screening China's Soft Power, London: Routledge, 2018, p.92.

3 See People's Daily China, Twitter post, 17 May 2019, online at: twitter.com/PDChina/status/1129282711695314944?ref_src=twsrc\%5Etfw\%7Ctwcamp\%5Etweetembed\%7Ctwterm\%5E1129901169906552833\&ref url=https\%3A\%2F\%2Fwww.inkstonenews. com\%2Fsociety\%2Ftaiwans-move-legalize-gay-marriage-wins-hearts-across-strait\%2Farticle $\% 2 F 3011143$

4 Qin Chen, 'Taiwan legalized gay marriage, and mainland China is all over it', Inkstone News, 21 May 2019, online at: www.inkstonenews.com/society/taiwans-move-legalize-gay-marriagewins-hearts-across-strait/article/3011143

5 See Jamie J. Zhao, 'Censoring “rainbow” in China', Asia Dialogue, 1 June 2018, online at: www. theasiadialogue.com/2018/06/01/censoring-rainbow-in-china/

6 Ibid.

7 Jiayun Feng, 'Same-sex couples in mainland China are naming their partners as legal guardians', SupChina, 6 August 2019, online at: supchina.com/2019/08/05/same-sex-couples-inmainland-china-are-naming-their-partners-as-legal-guardians/; and Katrin Büchenbacher, 'LGBT couples in China file for voluntary guardianship', CGTN, 11 August 2019, online at: news. cgtn.com/news/2019-08-09/LGBT-couples-in-China-file-for-voluntary-guardianship-J15eC8QcrC/index.html

8 Ibid.; and $\mathrm{Xu}$ Chen and Wilfred Wang, 'How China is legally recognising same-sex couples, but not empowering them', The Conversation, 2 October 2019, online at: theconversation.com/ how-china-is-legally-recognising-same-sex-couples-but-not-empowering-them-122270?fbclid=IwAR39GaRvfdmtH9VhLaJnic1lRBCNQ-CbrHT38NTZGN7ErqLiBpXgp5lhwPc

9 Kyle Mullin, 'China's acceptance of UN's LGBT recommendations prompts cautious optimism', The Beijinger, 1 April 2019, online at: www.thebeijinger.com/blog/2019/04/01/chinas-acceptance-un-lgbt--cautious-optimism; and Chen and Wang, 'How China is legally recognising same-sex couples'.

10 The Shanghai Queer Film Festival was started in September 2017. See Rebecca Davis, 'How the ShanghaiPRIDE Festival is coming out of SIFF's shadow', Variety, 22 June 2019, online at: $\quad$ variety.com/2019/film/news/shanghai-international-film-festival-shanghaipride-lg- 
btq-china-1203250794/. For China's censoring of homosexual content in the media, see Lianrui Jia and Tianyang Zhou, 'Regulation of homosexuality in the Chinese media scene', Asia Dialogue, 28 July 2015, online at: theasiadialogue.com/2015/07/28/regulation-of-homosexuality-in-the-chinese-media-scene/

11 Ibid.

12 See, 'A $\$ 300$ billion rainbow economy is booming in the middle of China', Bloomberg News, 19 June 2019, online at: www.bloomberg.com/news/articles/2019-06-18/chengdu-is-tappinginto-china-s-300-billion-rainbow-economy; and Ralph Jennings, 'LGBTs in China are priming a pink economy that will overtake America's', Forbes, 22 June 2017, online at: www.forbes. com/sites/ralphjennings/2017/06/22/chinas-pink-economy-is-quietly-but-quickly-growing-to-american-proportions/

${ }^{13}$ VICE Staff, 'The queens living it up in China's thriving drag scene', VICE, 6 June 2018, online at: www.vice.com/en au/article/zm8qya/the-queens-living-it-up-in-chinas-thriving-dragscene

${ }^{14}$ See, Chen and Wang, 'How China is legally recognising same-sex couples'; and Zhao, 'Censoring "rainbow" in China'.

${ }^{15}$ James Griffiths, ‘Can you be gay online in China? Social media companies aren’t sure', CNN Business, 17 April 2019, online at: edition.cnn.com/2019/04/17/tech/weibo-china-censorship-lgbt-intl/index.html

${ }^{16}$ Ibid.

\section{CHAPTER 5 - AI Dreams and Authoritarian Nightmares}

1 See Jeffrey Ding, Deciphering China's AI Dream: The Context, Components, Capabilities, and Consequences of China's Strategy to Lead the World in AI, Oxford: Future of Humanity Institute, University of Oxford, March 2018, online at: www.fhi.ox.ac.uk/wp-content/uploads/Deciphering Chinas AI-Dream.pdf

2 Ford Motor Company, Looking Further with Ford: 2018 Trends, Detroit: Ford Motor Company, 2018, online at: social.ford.com/content/dam/fordsocial/en US/articles/fords-2018-trendreport-what-to-know-about-the-year-ahead/2018\%20Looking_Further_with_Ford_ Trend\%20Report .pdf

3 Jeff Loucks, Susanne Hupfer, David Jarvis, and Timothy Murphy, Future in the Balance? How Countries are Pursuing an AI Advantage: Insights from Deloitte's State of AI in the Enterprise, 2nd Edition Survey, London: Deloitte, 2020, online at: www2.deloitte.com/us/en/insights/focus/ cognitive-technologies/ai-investment-by-country.html

4 Tanner Greer, '48 ways to get sent to a Chinese concentration camp', Foreign Policy, 13 September 2018, online at: foreignpolicy.com/2018/09/13/48-ways-to-get-sent-to-a-chinese-concentration-camp/

5 See Graham Webster, Roger Creemers, Paul Triolo, and Elsa Kasia, 'Full translation: China's "New Generation Artificial Intelligence Development Plan” (2017)', New America, 1 August 2017, online at: www.newamerica.org/cybersecurity-initiative/digichina/blog/full-translation-chinas-new-generation-artificial-intelligence-development-plan-2017/

6 Lizzie Dearden, 'Facial recognition wrongly identifies public as potential criminals $96 \%$ of time, figures reveal', The Independent, 7 May 2019, online at: www.independent.co.uk/news/uk/ home-news/facial-recognition-london-inaccurate-met-police-trials-a8898946.html 
7 Rashida Richardson, Jason M. Schultz, and Kate Crawford, 'Dirty data, bad predictions: How civil rights violations impact police data, predictive policing systems, and justice', NYU Law Review, May 2019, online at: www.nyulawreview.org/wp-content/uploads/2019/04/NYULawReview-94-Richardson-Schultz-Crawford.pdf

8 Human Rights Watch, China's Algorithms of Repression: Reverse Engineering a Xinjiang Police Mass Surveillance App, New York: Human Rights Watch, 1 May 2019, online at: www.hrw. org/report/2019/05/01/chinas-algorithms-repression/reverse-engineering-xinjiang-police-mass-surveillance

9 Cathy O'Neil, 'The era of blind faith in big data must end', TED Conferences, 7 September 2017, online at: www.ted.com/talks/cathy o neil the era of blind faith in big data must end

10 Zak Doffman, 'China deploys "breakthrough" surveillance technology to arrest 13,000 "terrorists”', Forbes, 18 March 2019, online at: www.forbes.com/sites/zakdoffman/2019/03/18/xinjiang-claims-13000-terrorist-arrests-justify-high-tech-population-control/\#318b2241455c

${ }^{11}$ Simon Denyer, 'China's watchful eye', The Washington Post, 7 January 2018, online at: www. washingtonpost.com/news/world/wp/2018/01/07/feature/in-china-facial-recognition-issharp-end-of-a-drive-for-total-surveillance/

12 Josh Rudolph, 'Sharper eyes: Surveilling the surveillers (Part 1)', China Digital Times, 9 September 2019, online at: chinadigitaltimes.net/2019/09/sharper-eyes-surveilling-the-surveillers-part-1/

${ }^{13}$ Louise Matsakis, 'How the West got China's Social Credit System wrong', WIRED, 29 July 2019, online at: www.wired.com/story/china-social-credit-score-system/

${ }^{14}$ Daniel Castro, Michael McLaughlin, and Eline Chivot, Who is Winning the AI Race: China, the EU or the United States?, Washington, DC: Center for Data Innovation, August 2019, online at: www2.datainnovation.org/2019-china-eu-us-ai.pdf

${ }^{15}$ Samantha Hoffman, Engineering Global Consent: The Chinese Communist Party's Data-Driven Power Expansion, Canberra: Australian Strategic Policy Institute, October 2019, online at: www. aspi.org.au/report/engineering-global-consent-chinese-communist-partys-data-driven-power-expansion

${ }^{16}$ Chinese Academy of Sciences, China's AI Business Ready to Lead the World, Beijing: Chinese Academy of Sciences, 2 June 2017, online at: english.cas.cn/newsroom/news/201706/ t20170602 177674.shtml

17 'Baidu chief under fire for privacy comments', CRI Online, 28 March 2018, online at: en.people. $\mathrm{cn} / \mathrm{n} 3 / 2018 / 0328 / \mathrm{c} 90000-9442509 . \mathrm{html}$

18 Samm Sacks, 'China's emerging data privacy system and GDPR', Commentary, Washington, DC: Center for Strategic and International Studies, 9 March 2018, online at: www.csis.org/analysis/ chinas-emerging-data-privacy-system-and-gdpr

${ }^{19}$ Cao Yin, 'Illegal data collection by apps targeted', China Daily, 26 January 2019, online at: www. chinadaily.com.cn/a/201901/26/WS5c4ba316a3106c65c34e69ea.html

${ }^{20}$ Rogier Creemers, Paul Triolo, and Graham Webster, 'Translation: Cybersecurity Law of the People's Republic of China (Effective June 1, 2017)', New America, 29 June 2018, online at: www.newamerica.org/cybersecurity-initiative/digichina/blog/translation-cybersecurity-law-peoples-republic-china/

${ }^{21}$ Human Rights Watch, China: Police 'Big Data’ Systems Violate Privacy, Target Dissent, New York: Human Rights Watch, 19 November 2017, online at: www.hrw.org/news/2017/11/19/china-police-big-data-systems-violate-privacy-target-dissent 
${ }^{22}$ Nick Statt, 'China is fighting toilet paper thieves with facial recognition software', The Verge, 20 March 2017, online at: www.theverge.com/2017/3/20/14986640/china-toilet-paper-theft-facial-recognition-machine

${ }^{23}$ Nector Gan, 'China's internet regulator orders online AI algorithms to promote "mainstream values”, South China Morning Post, 11 September 2019, online at: www.scmp.com/news/ china/politics/article/3026784/chinas-internet-regulator-orders-online-ai-algorithms-promote

${ }^{24}$ Frank Hersey, 'Almost $80 \%$ of Chinese concerned about AI threat to privacy, $32 \%$ already feel a threat to their work', TechNode, 2 March 2018, online at: technode.com/2018/03/02/almost-80chinese-concerned-ai-threat-privacy-32-already-feel-threat-work/

${ }^{25}$ Jeffrey Ding, Paul Triolo, and Samm Sacks, 'Chinese interests take a big seat at the AI governance table', New America, 20 June 2018, online at: www.newamerica.org/cybersecurity-initiative/ digichina/blog/chinese-interests-take-big-seat-ai-governance-table/

${ }^{26}$ Beijing Academy of Artificial Intelligence, Beijing AI Principles, Beijing: Beijing Academy of Artificial Intelligence, 28 May 2019, online at: www.baai.ac.cn/blog/beijing-ai-principles

27 See the OECD Principles on AI at: www.oecd.org/going-digital/ai/principles/; and the G20 AI Principles in: www.mofa.go.jp/files/000486596.pdf. China also signed on to the G20 AI Principles as a G20 member.

${ }^{28}$ Ana Swanson and Paul Mozur, 'US blacklists 28 Chinese entities over abuses in Xinjiang', The New York Times, 7 October 2019, online at: www.nytimes.com/2019/10/07/us/politics/us-toblacklist-28-chinese-entities-over-abuses-in-xinjiang.html

${ }^{29}$ Amy K. Lehr and Efthimia Maria Bechrakis, 'The US blacklisted 28 Chinese entities over repression of Muslim minorities in Xinjiang. What does this mean for human rights?', Critical Questions, Washington, DC: Center for Strategic and International Studies, 11 October 2019, online at: www.csis.org/analysis/united-states-blacklisted-28-chinese-entities-over-repression-muslim-minorities-xinjiang

${ }^{30}$ Cal Jeffrey, 'Controversial search engine Project Dragonfly "terminated" Google VP tells Congress', TechSpot, 17 July 2019, online at: www.techspot.com/news/81003-controversial-search-engine-project-dragonfly-terminated-google-vp.html

${ }^{31}$ Sui-Lee Wee, 'China uses DNA to track its people, with the help of American expertise', The New York Times, 21 February 2019, online at: www.nytimes.com/2019/02/21/business/china-xinjiang-uighur-dna-thermo-fisher.html?emc=edit th $190222 \& n l=$ todaysheadlines\&n$\underline{\text { lid }=878883400222}$

32 Ibid.

${ }^{33}$ Sophie McNeill, Jeanavive McGregor, Meredith Griffiths, Michael Walsh, and Echo Hui, 'UTS, Curtin unis announce reviews over links to surveillance tech used by Chinese Government', ABC News, 16 July 2019, online at: www.abc.net.au/news/2019-07-16/australian-unis-to-review-links-to-chinese-surveillance-tech/11309598

${ }^{34}$ James A. Lewis, Learning the Superior Techniques of the Barbarians: China's Pursuit of Semiconductor Independence, China Innovation Policy Series, Washington, DC: Center for Strategic and International Studies, January 2019, online at: csis-prod.s3.amazonaws.com/s3fs-public/ publication/190115 Lewis Semiconductor v6.pdf

${ }^{35}$ Lulu Yilun Chen, 'China claims more patents than any country - most are worthless', Bloomberg, 26 September 2018, online at: www.bloomberg.com/news/articles/2018-09-26/chinaclaims-more-patents-than-any-country-most-are-worthless 
${ }^{36}$ David Zweig and Huiyao Wang, 'Can China bring back the best? The Communist Party organizes China's search for talent', The China Quarterly, 12 September 2013: 590-615.

${ }^{37}$ Steven Feldstein, 'China is exporting AI surveillance technology to countries around the world', Newsweek, 23 April 2019, online at: www.newsweek.com/china-ai-surveillance-technology-world-1403762

${ }^{38}$ Amy Webb, The Big Nine, New York: Public Affairs, 2019, p.120.

39 Bing Song, 'The West may be wrong about China's Social Credit System', The Washington Post, 30 November 2018, online at: www.washingtonpost.com/news/theworldpost/wp/2018/11/29/ social-credit/?noredirect $=$ on

${ }^{40}$ Charles Rollet, 'China public video surveillance guide: From Skynet to Sharp Eyes', IPVM, 14 June 2018, online at: ipvm.com/reports/sharpeyes

${ }^{41}$ Alexandra Ma, 'China reportedly made an app to show people if they're standing near someone in debt - a new part of its intrusive "social credit” policy', Business Insider, 23 January 2019, online at: www.businessinsider.com/china-app-shows-map-of-people-in-debt-for-socialcredit-system-report-2019-1

\section{FORUM — Life and Death}

\section{Dream Babies}

1 The He Lab, 'About Lulu and Nana: Twin girls born healthy after gene surgery as single-cell embryos', YouTube, 25 November 2018, online at: www.youtube.com/watch?v=th0vnOmFltc

2 Sharon Begley, 'Amid uproar, Chinese scientist defends creating gene-edited babies', STAT, 28 November 2018, online at: www.statnews.com/2018/11/28/chinese-scientist-defends-creating-gene-edited-babies

3 Jon Cohen, 'The untold story of the "circle of trust" behind the world's first gene-edited babies', Science, 1 August 2019, online at: www.sciencemag.org/news/2019/08/untold-story-circletrust-behind-world-s-first-gene-edited-babies

4 Begley, 'Amid uproar, Chinese scientist defends creating gene-edited babies'.

5 Caroline Wagner, 'CRISPR babies and other ethical missteps in science threaten China's global standing', The Conversation, 4 December 2018, online at: theconversation.com/crispr-babies-and-other-ethical-missteps-in-science-threaten-chinas-global-standing-108009

6 George Estreich, 'YouTube, persuasion and genetically engineered children', The Conversation, 3 December 2018, online at: theconversation.com/youtube-persuasion-and-genetically-engineered-children-107938

7 Jon Cohen and Nirja Desai, 'With its CRISPR revolution, China becomes a world leader in genome editing', Science, 2 August 2019, online at: www.sciencemag.org/news/2019/08/its-crispr-revolution-china-becomes-world-leader-genome-editing

8 Elsie Chen and Paul Mozur, 'Chinese scientist who claimed to make genetically edited babies is kept under guard', The New York Times, 28 December 2018, online at: www.nytimes. com/2018/12/28/world/asia/he-jiankui-china-scientist-gene-editing.html

9 Ian Sample, 'Chinese scientist who edited babies' genes jailed for three years', The Guardian, 31 December 2019, online at: www.theguardian.com/world/2019/dec/30/gene-editing-chinesescientist-he-jiankui-jailed-three-years 
${ }^{10}$ David Lawrence, 'Genetic engineering and human-animal hybrids: How China is leading a global split in controversial research', The Conversation, 3 September 2019, online at: theconversation.com/genetic-engineering-and-human-animal-hybrids-how-china-is-leading-a-global-split-in-controversial-research-121473

${ }_{11}$ Manuel Ansede, 'Spanish scientists create human-monkey chimera in China', El País, 31 July 2019, online at: elpais.com/elpais/2019/07/31/inenglish/1564561365 256842.html

${ }_{12}$ Michael Le Page, 'Exclusive: Two pigs engineered to have monkey cells born in China', New Scientist, 6 December 2019, online at: www.newscientist.com/article/2226490-exclusive-twopigs-engineered-to-have-monkey-cells-born-in-china/

${ }^{13}$ Jane Brophy, 'Navigating the "Grey Areas”: Australian Medical Travellers in China’s Stem Cell Bionetwork', Asia Pacific Viewpoint, vol.58, no.2 (2017): 216-227.

${ }^{14}$ Aihua Ong, 'Introduction: An analysis of biotechnology and ethics at multiple scales', in Aihua Ong and Nancy N. Chen eds, Asian Biotech: Ethics and Communities of Fate, Durham, NC: Duke University Press, 2010, pp.1-54, at p.33.

${ }^{15}$ Antonio Regalado, 'China's CRISPR babies: Read exclusive excerpts from the unseen original research', MIT Technology Review, 3 December 2019, online at: www.technologyreview. com/s/614764/chinas-crispr-babies-read-exclusive-excerpts-he-jiankui-paper/

${ }^{16}$ Cohen, 'The untold story of the "circle of trust” behind the world's first gene-edited babies'.

17 Regalado, 'China's CRISPR babies'.

18 David Cyranoski, 'China set to introduce gene-editing regulation following CRISPR-baby furore', Nature, 20 May 2019, online at: www.nature.com/articles/d41586-019-01580-1

${ }^{19}$ Jon Cohen, 'Embattled Russian scientist sharpens plans to create gene-edited babies', Science, 21 October 2019, online at: www.sciencemag.org/news/2019/10/embattled-russian-scientist-sharpens-plans-create-gene-edited-babies

${ }^{20}$ David Cyranoski, 'Russian "CRISPR-baby" scientist has started editing genes in human eggs with goal of altering deaf gene', Nature, 18 October 2019, online at: www.nature.com/articles/ d41586-019-03018-0

\section{Recurring Nightmare: The Plague Visits Beijing}

1 Sean Martin, 'Bubonic plague: Third case of plague in China as panic begins - "The plague is coming”', Express, 19 November 2019, online at: www.express.co.uk/news/science/1205992/ bubonic-plague-china-plague-news-the-plague-pneumonic-plague-in-china-2019-symp$\underline{\text { toms }}$

2 World Health Organisation, 'Plague', Fact Sheet, Geneva: WHO, 31 October 2017, online at: www.who.int/en/news-room/fact-sheets/detail/plague

3 Caixin, 'Gallery: Catching plague rats on the Tibetan Plateau', Caixin, 13 November 2019, online at: $\quad$ www.caixinglobal.com/2019-11-13/gallery-catching-plague-rats-on-the-tibetan-plateau-101482935.html

4 World Health Organisation and Pandemic \& Epidemic Diseases, 'Global distribution of natural plague foci as of March 2016', Geneva: WHO, 15 March 2016, online at: www.who.int/images/ default-source/health-topics/plague/plague-map-2016.png?sfvrsn=68bcc3ee 4

5 Sui-Lee Wee, 'Pneumonic plague is diagnosed in China', The New York Times, 13 November 2019, online at: www.nytimes.com/2019/11/13/world/asia/plague-china-pneumonic.html 
6 Yu Juan, Ma Danmeng, Liang Zhen, and Denise Jia, 'Two persons diagnosed with pneumonic plague in Beijing', CX Tech, 13 November 2019, online at: www.caixinglobal.com/2019-11-13/ two-persons-diagnosed-with-pneumonic-plague-in-beijing-101482664.html

7 Laurie Garrett, 'The real reason to panic about China's plague outbreak', Foreign Policy, 16 November 2019, online at: foreignpolicy.com/2019/11/16/china-bubonic-plague-outbreak-pandemic/

8 Yu et al., 'Two persons diagnosed with pneumonic plague in Beijing'.

9 Flynn Murphy and Zhao Jinzhao, 'Beijing plague patients were medical transfers, further cases in capital unlikely: Officials', Caixin, 14 November 2019, online at: www.caixinglobal. com/2019-11-14/beijing-plague-patients-were-medically-transferred-from-inner-mongo$\underline{\text { lia-101483498.html }}$

${ }^{10}$ Ibid.

11 'Third plague pandemic', Wikipedia, 23 November 2019, online at: en.wikipedia.org/wiki/ Third_plague_pandemic\#cite_note-2; Nils Chr. Stenseth, 'Plague Through History', Science, vol.321, no.5890 (2008): 773-774, doi.org/10.1126/science.1161496; Sarah Lynar, Bart J. Currie, and Robert Baird, 'Scabies and Mortality', The Lancet: Infectious Diseases, vol.17, no.12 (2017): 1234, doi.org/10.1016/S1473-3099(17)30636-9.

${ }^{12}$ Liang Zhen, Zhao Yinchao, Yu Juan, Ren Qiuyu, and Flynn Murphy, 'In depth: North China region scrambles to prevent plague's spread after scare in Beijing', CX Tech, 26 November 2019, online at: www.caixinglobal.com/2019-11-26/in-depth-north-china-region-scrambles-to-preventplagues-spread-after-scare-in-beijing-101487584.html

${ }_{13}$ Ibid.

${ }_{14}$ Xinhua, 'Inner Mongolia combats rat plague’, Xinhua, 11 May 2018, online at: www.xinhuanet. com/english/2018-05/11/c 137172364.htm

15 Tamara Ben-Ari, Simon Neerinckx, Kenneth L. Gage, Katharina Kreppel, Anne Laudisoit, Herwig Leirs, and Nils Chr. Stenseth, 'Plague and Climate: Scales Matter', PLoS Pathogens, vol.7, no.9 (September 2011): e1002160, doi.org/10.1371/journal.ppat.1002160.

\section{CHAPTER 6 - Urbanising Tibet: Aspirations, Illusions, and Nightmares}

1 Françoise Robin, 'Discussing rights and human rights in Tibet', in Ben Hillman and Gray Tuttle eds, Ethnic Conflict and Protest in Tibet and Xinjiang: Unrest in China’s West, New York: Columbia University Press, 2016, pp.60-96.

2 Ben Hillman, 'Unrest in Tibet and the limits of regional autonomy', in Ben Hillman and Gray Tuttle eds, Ethnic Conflict and Protest in Tibet and Xinjiang: Unrest in China's West, New York: Columbia University Press, 2016, pp.18-39.

3 See Ben Hillman and Lee-Anne Henfry, 'Macho Minority: Masculinity and Ethnicity on the Edge of Tibet', Modern China, vol.32 (April 2006): 251-272.

4 'Great leap: 60 years of democratic reform in Tibet', Xinhua, 27 March 2019, online at: www. xinhuanet.com/local/2019-03/27/c $11242878734 . \mathrm{htm}$

5 Ben Hillman and Gray Tuttle eds, Ethnic Conflict and Protest in Tibet and Xinjiang: Unrest in China's West, New York: Columbia University Press, 2016.

6 Estimate based on calculations from multiple state media reports. 
7 James Leibold, 'Interethnic conflict in the PRC: Xinjiang and Tibet as exceptions?', in Ben Hillman and Gray Tuttle eds, Ethnic Conflict and Protest in Tibet and Xinjiang: Unrest in China's West, New York: Columbia University Press, 2016, pp.223-250.

8 James Leibold, 'China’s ethnic policy under Xi Jinping', China Brief, vol.15, no.20 (October 2015), online at: jamestown.org/program/chinas-ethnic-policy-under-xi-jinping/; James Leibold, 'China's minority report: When racial harmony means homogenization', Foreign Affairs, 23 March 2016, online at: www.foreignaffairs.com/articles/china/2016-03-23/chinas-minority-report

9 Xi Jinping, 'Speech at the National Ethnic Unity Awards Ceremony' 习近平：在全国民族团结进步 表彰大会上的讲话, Xinhua, 27 September 2019, online at: www.xinhuanet.com/politics/leaders/2019-09/27/c 1125049000.htm

10 Chinese Communist Party Central Committee, National New Urbanization Plan, 2014-2020, Beijing: Renmin Chubanshe, 2014.

${ }^{11}$ State Council of the People's Republic of China, 'State Council Notice of the 13th Five Year Plan to Promote the Development of Ethnic Minority Regions and Ethnic Groups with Small Populations' 国务院关于印发“十三五”促进民族地区和人口较少民族发展规划的通知, 24 January 2017, online at: www.gov.cn/zhengce/content/2017-01/24/content 5162950.htm

12 Ma Rong, 'Evolutions of ethnic relations during the process of China's urbanization' 中国城镇化 进程中的民族关系演变, Northwest Journal of Ethnology 西北民族研究, vol.84 (2015): 19-34.

13 State Council of the People's Republic of China, 'Tibet's urbanization rate expected to exceed 30\% by 2020', Xinhua, 14 January 2015, online at: english.www.gov.cn/news/top news/2015/01/14/ content 281475039136272.htm

14 'Music video: “City” by Lobsang Nyima', High Peaks Pure Earth, 16 August 2018, online at: highpeakspureearth.com/2018/music-video-city-by-lobsang-nyima/

${ }^{15}$ Evelyn Peters and Chris Andersen, Indigenous in the City: Contemporary Identities and Cultural Innovation, Vancouver: UBC Press, 2015.

${ }^{16}$ Nick Estes, Our History Is the Future: Standing Rock Versus the Dakota Access Pipeline \& the Long Tradition of Indigenous Resistance, London: Verso, 2019.

17 'Music video: "Fly" by ANU', High Peaks Pure Earth, 19 July 2017, online at: highpeakspureearth.com/2017/music-video-fly-by-anu/

${ }^{18}$ Eli Friedman, 'Just-In-Time Urbanization? Managing Migration, Citizenship, and Schooling in the Chinese City', Critical Sociology, vol.44, no.3 (2018): 503-518.

${ }^{19}$ Luo Xiaofei, Wang Jun, and Bai Shaobo, 'New clusters of cities along the Qinghai-Tibet railway' 青藏铁路沿线崛起新城市群, Xinhua Daily Telegraph, 27 June 2016, online at: www.xinhuanet. com/mrdx/2016-06/27/c 135468232.htm

20 'Two music videos by Uncle Buddhist: "Do Whatever You Want (Phantoms of Youth)" and “Tsampa”, High Peak Pure Earth, 29 June 2018, online at: highpeakspureearth.com/2018/twomusic-videos-by-uncle-buddhist-do-whatever-you-want-phantoms-of-youth-and-tsampa/

${ }^{21} \mathrm{Xi}$, 'Speech at the National Ethnic Unity Awards Ceremony'.

${ }^{22}$ Jeremy Wallace, Cities and Stability: Urbanization, Redistribution, and Regime Survival in China, Oxford: Oxford University Press, 2014.

${ }^{23}$ State Council, 'State Council Notice of the 13th Five Year Plan to Promote the Development of Ethnic Minority Regions and Ethnic Groups with Small Populations'. 


\section{FORUM — Forgotten Histories}

\section{'Prairie Mothers' and Shanghai Orphans}

1 'The awarding ceremony of the National Medal and the National Honours of the People's Republic of China will be held grandly' 中华人民共和国国家勋章和国家㭉誉称号颁授仪式将隆重举行, Xinhua, 27 September 2019, online at: www.xinhuanet.com/politics/2019-09/27/c 1125049436.htm

2 A 'banner' is an administrative unit in Inner Mongolia that corresponds to a county-level division. Banners are ethnic autonomous units of administration, which means they have more flexibility in implementing government policy and more scope to enact regulations that are adapted to local conditions.

3 Zhang Jinxi 张锦贻, 'Nature of Nationality, Sense of History and Spirit of the Times: A Review of “Three Thousand Orphans and their Prairie Mothers”' 民族性, 历史感, 时代精神: 评“三千孤儿与草 原母亲, Inner Mongolia Education 内蒙古教育, no.6 (1998): 45-46.

4 Wu Congling 吴聪灵, ‘50,000 “Shanghai orphans” looking for loved ones’ 五万‘上海孤儿’的寻亲 路, China Folklore, 2 September 2007, online at: www.chinesefolklore.com/news/news detail. asp?id=1330

5 “'Shanghai Orphans” search for loved ones: A half a century of search and reunion' ‘上海孤 儿’的寻亲活动: 跨越半个世纪的寻找与团聚, CCTV News, 21 March 2015, online at: m.news.cntv. cn/2015/03/21/ARTI1426909665882731.shtml

\section{CHAPTER 7 - Schemes, Dreams, and Nightmares: China's Paradox(es) of Trust}

1 Lily Kuo, 'China bans 23m from buying travel tickets as part of "social credit” system', The Guardian, 2 March 2019, online at: www.theguardian.com/world/2019/mar/01/china-bans-23m-discredited-citizens-from-buying-travel-tickets-social-credit-system

2 Manya Koetse, “Be As Good As Your Word”: The Chinese social credit song is here', What's on Weibo, [China Insight], 30 April 2019, online at: www.whatsonweibo.com/be-as-good-as-yourword-the-chinese-social-credit-song-is-here/

3 State Council of the PRC, Notice of the State Council on Printing and Distributing the Outline of the Construction of the Social Credit System (2014-2020) 国务院关于印发社会信用体系建设规划纲 要(2014-2020年)的通知, Beijing: State Council, 27 June 2014, online at: www.gov.cn/zhengce/ content/2014-06/27/content 8913.htm

4 John Naughton, “"We Have Been Harmonised: Life in China’s Surveillance State” by Kai Strittmatter - Review’, The Guardian, 30 June 2019, online at: www.theguardian.com/books/2019/ jun/30/we-have-been-harmonised-life-china-surveillance-state-kai-strittmatter-review

5 Jane Zhang, 'In Chongqing, the world's most surveilled city, residents are happy to trade privacy for security', South China Morning Post, 4 October 2019, online at: www.scmp.com/tech/policy/ article/3031390/chongqing-worlds-most-surveilled-city-these-residents-are-happy-trade

6 Luana Pascu, 'China introduces facial recognition for WeChat transfers, mandatory biometric scans for SIM cards', Biometric Update, 2 December 2019, online at: www.biometricupdate. com/201912/china-introduces-facial-recognition-for-wechat-transfers-mandatory-biometric-scans-for-sim-cards 
7 Sui-Lee Wee and Paul Mazur, 'China uses DNA to map faces, with help from the West', The New York Times, 3 December 2019, online at: www.nytimes.com/2019/12/03/business/china-dna-uighurs-xinjiang.html

8 Steve Dickinson, 'China's new cybersecurity program: No place to hide', China Law Blog, 30 September 2019, online at: www.chinalawblog.com/2019/09/chinas-new-cybersecurity-program-no-place-to-hide.html

9 William Zheng, 'Big data expert takes over as China's new cybersecurity chief', South China Morning Post, 27 September 2019, online at: www.scmp.com/news/china/politics/article/3030563/big-data-expert-takes-over-chinas-new-cybersecurity-chief

10 Anna Fifield, 'Chinese app on Xi's ideology allows data access to users' phones, report says', The Washington Post, 13 October 2019, online at: www.washingtonpost.com/world/asia pacific/ chinese-app-on-xis-ideology-allows-data-access-to-100-million-users-phones-reportsays/2019/10/11/2d53bbae-eb4d-11e9-bafb-da248f8d5734 story.html

${ }^{11}$ Li Tao, 'Jaywalkers under surveillance in Shenzhen soon to be punished via text messages', South China Morning Post, 27 March 2018, online at: www.scmp.com/tech/china-tech/article/2138960/jaywalkers-under-surveillance-shenzhen-soon-be-punished-text

12 This idea was first proposed by Delia Lin and Gerry Groot in a paper presented at a Chinese Studies Association of Australia Conference in 2011, 'Ai Weiwei's arrest: Why him, why now? Challenges to the paradox of trust'.

13 'Xi stresses development, application of block chain technology', Xinhua, 25 October 2019, online at: www.xinhuanet.com/english/2019-10/25/c 138503254.htm

${ }^{14}$ Nigel Holt, 'Majority of people return lost wallets: Here's the psychology and which countries are the most honest', The Conversation, 21 June 2019, online at: theconversation.com/majority-of-people-return-lost-wallets-heres-the-psychology-and-which-countries-are-the-mosthonest-119118

${ }^{15}$ Alain Cohn, Michel André Maréchal, David Tannenbaum, and Christian Lukas Zünd, 'Civic Honesty Around the Globe', Science, vol.365, no.6448 (5 July 2019): 70-73, online at: science. sciencemag.org/content/365/6448/70/tab-e-letters

${ }^{16}$ See John Osburg, Anxious Wealth: Money and Morality among China's New Rich, Stanford, CA: Stanford University Press, 2013.

17 National Public Complaints and Proposals Administration, online at: www.gjxfj.gov.cn/gjxfj/ index.htm. There was a blow to this office when, in 2017, one of its most senior officials was himself exposed as corrupt. See Reuters, 'Corruption at top rung of China's ancient petition system sparks calls for reform', South China Morning Post, 11 April 2017, online at: www.scmp. com/news/china/policies-politics/article/2086741/corruption-top-rung-chinas-ancient-petition-system

${ }_{18}$ Niall McCarthy, 'The countries that trust their government most and least', Forbes, 22 January 2018, online at: www.forbes.com/sites/niallmccarthy/2018/01/22/the-countries-that-trusttheir-government-most-and-least-infographic/\#49c3eb7777a6

19 Séverine Arsène, China's Social Credit System: A chimera with claws, Policy Paper: Asie Visions, no.110, Paris: French Institute of International Relations, 29 November 2019, p.3.

20 Credit China, online at: www.creditchina.gov.cn/

${ }^{21}$ Jeremy Daum, 'Keeping track of social credit', China Law Translate, 24 September 2019, online at: www.chinalawtranslate.com/en/keeping-track-of-social-credit/ 
22 State Council of the PRC, Planning Outline for the Establishment of a Social Credit System (20142020), translated by Jeremy Daum (China Law Translate, 27 April 2015). In Arsène, China's Social Credit System, p.8.

${ }^{23}$ Dev Lewis, 'All carrots and no sticks: A case study on social credit scores in Xiamen and Fuzhou', Medium, 4 October 2019, online at: medium.com/berkman-klein-center/social-credit-casestudy-city-citizen-scores-in-xiamen-and-fuzhou-2a65feb2bbb3

${ }^{24}$ Ibid.

${ }^{25}$ Arsène, China's Social Credit System, pp.18-19.

${ }^{26}$ Ibid., p.21.

27 Ibid., p.22.

${ }^{28}$ Meng Jing, 'This small team is building a Social Credit System app for China's youth to determine who's naughty or nice', South China Morning Post, 25 March 2019, online at: www.scmp.com/ tech/apps-social/article/3003158/small-team-building-social-credit-system-app-chinasyouth

${ }^{29}$ Arsène, China's Social Credit System, p.22.

30 'Tiananmen Square, 30 years later', CBS News, 2 June 2019, online at: www.cbsnews.com/ news/tiananmen-square-30-years-later/

${ }^{31}$ James T. Areddy, 'One legacy of Tiananmen: China's 100 million surveillance cameras', The Wall Street Journal, 5 June 2014, online at: blogs.wsj.com/chinarealtime/2014/06/05/one-legacy-of-tiananmen-chinas-100-million-surveillance-cameras/

32 Chris Buckley and Paul Mozur, 'How China uses high-tech surveillance to subdue minorities', The New York Times, 22 May 2019, online at: www.nytimes.com/2019/05/22/world/asia/china-surveillance-xinjiang.html

${ }^{33}$ Human Rights Watch, China: Big Data Fuels Crackdown in Minority Region, New York: Human Rights Watch, 26 February 2018, online at: www.hrw.org/print/315321

${ }^{34}$ Li Tao, 'SenseNets: The facial recognition company that supplies China's Skynet surveillance system', South China Morning Post, 12 April 2019, online at: www.scmp.com/tech/science-research/article/3005733/what-you-need-know-about-sensenets-facial-recognition-firm; and Lily Kuo, 'Chinese surveillance company tracking 2.5m Xinjiang residents', The Guardian, 19 February 2019, online at: www.theguardian.com/world/2019/feb/18/chinese-surveillance-company-tracking-25m-xinjiang-residents

35 Emile Dirks, “Key Individuals Management” and the Roots of China's Anti-Muslim Surveillance System', China Brief, vol.19, no.16 (6 September 2019), online at: jamestown.org/program/ key-individuals-management-and-the-roots-of-chinas-anti-muslim-surveillance-system/

${ }^{36}$ Ibid.

${ }^{37}$ Chris Stokel-Walker, 'TikTok may be leaking people's data from the US to China', New Scientist, 5 December 2019, online at: www.newscientist.com/article/2226388-tiktok-may-be-leakingpeoples-data-from-the-us-to-china/. Elsewhere, video clips by disabled, queer, and overweight creators were also suppressed. See, Elena Botella, 'TikTok admits it suppressed videos by disabled, queer, and fat creators', Slate, 4 December 2019, online at: slate.com/technology/2019/12/ tiktok-disabled-users-videos-suppressed.html; 'US teenager's TikTok video on Uyghur "concentration camps" in China's Xinjiang goes viral', ABC News, 27 November 2019, online at: www.abc.net.au/news/2019-11-27/us-teenagers-tiktok-video-on-uyghur-muslims-goes-vi$\underline{\mathrm{ral} / 11741352}$ 
${ }^{38}$ Steven Feldstein, The Global Expansion of AI Surveillance, Paper, Washington, DC: Carnegie Endowment for International Peace, 17 September 2019, online at: carnegieendowment. org/2019/09/17/global-expansion-of-ai-surveillance-pub-79847

${ }^{39}$ Nicole Hong, 'A military camera said “Made in U.S.A.”: The screen was in Chinese', The New York Times, 7 November 2019, online at: www.nytimes.com/2019/11/07/nyregion/aventura-china-cameras.html

${ }^{40}$ Yuan Yang and Nian Liu, 'China survey shows high concern over facial recognition abuse', Financial Times, 5 December 2019, online at: www.ft.com/content/7c32c7a8-172e-11ea-9ee4$11 \mathrm{f} 260415385$

${ }^{41}$ Kerry Allen, 'China facial recognition: Law professor sues wildlife park', BBC Monitoring, 8 November 2019, online at: www.bbc.com/news/world-asia-china-50324342

42 Jeffrey Ding, 'ChinAI \#77: A strong argument against facial recognition in the Beijing subway', ChinAI Newsletter, 10 December 2019, online at: chinai.substack.com/p/chinai-77-a-strongargument-against

${ }^{43}$ Dirks, “'Key Individuals Management” and the Roots of China's Anti-Muslim Surveillance System'.

${ }^{44}$ Human Rights Watch, China: Minority Region Collects DNA from Millions, New York: Human Rights Watch, 13 December 2017, online at: www.hrw.org/news/2017/12/13/china-minority-region-collects-dna-millions

\section{FORUM — Vigilante Justice}

\section{Taking Justice into their Own Hands: 'Netilantism' in Hong Kong}

1 See Thomas L. Friedman, 'Hong Kong's protests could be another social media revolution that ends in failure', The New York Times, 17 September 2019, online at: www.nytimes.com/ 2019/09/17/opinion/hong-kong-protest.html? ga=2.268138446.1753451604.1578351700$\underline{365025616.1578351700}$

2 Lennon Y.C. Chang and Ryan Poon, 'Internet Vigilantism: Attitudes and Experiences of University Students in Hong Kong', International Journal of Offender Therapy and Comparative Criminology, vol.61, no.16 (2017): 1912-1932.

3 See Hong Kong Free Press, 'Hong Kong's expat police officers targeted by protesters as doing Beijing's bidding', Hong Kong Free Press, 17 July 2019, online at: https://www.hongkongfp. com/2019/07/17/hong-kongs-expat-police-officers-targeted-protesters-beijings-bidding/

4 Esther Chan and Rachel Blundy, “Bulletproof” China-backed doxxing site attacks Hong Kong’s democracy activists', Hong Kong Free Press, 1 November 2019, online at: www.hongkongfp. com/2019/11/01/bulletproof-china-backed-doxxing-site-attacks-hong-kongs-democracy-activists

\section{CHAPTER 8 - Hong Kong and the Tiananmen Playbook}

1 Bao Pu ed., The Last Secret: The Final Documents from the June Fourth Crackdown 最後的秘 密——共十三届四中全會「六四」結諭文, Hong Kong: New Century Press, 2019.

2 Andrew J. Nathan, 'The New Tiananmen Papers: Inside the Secret Meeting that Changed China', Foreign Affairs, vol.98 (July-August 2019): 80-91. 
3 Ben Hillman, 'Unrest in Tibet and the limits of regional autonomy', in Ben Hillman and Gray Tuttle eds, Ethnic Conflict and Protest in Tibet and Xinjiang: Unrest in China's West, New York: Columbia University Press, 2016, pp.18-39.

4 Louisa Lim, The People's Republic of Amnesia: Tiananmen Revisited, New York: Oxford University Press, 2014.

\section{FORUM - Sharing the Dream?}

\section{South Korea and the 'China Effect'}

1 'South Korea's Lotte seeks to exit China after investing $\$ 9.6$ billion, as Thaad fallout ensues', Straits Times, 13 March 2019, online at: www.straitstimes.com/asia/east-asia/south-koreaslotte-seeks-to-exit-china-after-investing-96-billion

2 See John Power, 'US pressure on Seoul over Huawei taps into fears of North Korea', South China Morning Post, 26 June 2019, online at: www.scmp.com/week-asia/geopolitics/article/3016028/ us-pressure-seoul-over-huawei-taps-fears-north-korea; and Ju-min Park and Heekyong Yang, 'Huawei ban puts South Korea in a familiar place: Caught between the US and China', Reuters, 29 May 2019, online at: www.reuters.com/article/us-huawei-tech-usa-samsung-analysis/huawei-ban-puts-south-korea-in-a-familiar-place-caught-between-the-u-s-and-china-idUSKCN1SZ0AG

3 C.G. Kim, 'A Study on the Current State and Problems of Import and Export Concentration', Weekly Korean Economy, no.1 (2018): 1-15.

4 See Michael Schuman, 'The US can’t make allies take sides over China', The Atlantic, 25 April 2019, online at: www.theatlantic.com/international/archive/2019/04/us-allies-washington-china-belt-road/587902/

\section{Taiwanese Dreams: Security, Sovereignty, and the Space to be Seen}

1 Zhang Baida, 'Taiwan Dream and Chinese Dream: Contradictory as well as congruent’台灣萝與 中國萝 既矛盾又統一, Herald Today 今日導報, 16 May 2013, online at: www.herald-today.com/ content.php?sn=6201

2 Ching-yu Sun, 'When the Chinese Dream becomes bullying patriotism' 孫慶稌專欄：當「中國 夢」變霸凌式愛國主義, The Storm Media 風傳媒, 19 August 2019, online at: www.storm.mg/arti$\underline{\text { cle } / 1607269}$

3 Over $70 \%$ of Taiwanese support Hong Kong's anti-extradition protests, only 13.6\% support reunification' 台灣逾7成民眾支持反送中贊成統一僅剩13.6\%, Taiwan People News 民報, 24 June 2019, online at: www.peoplenews.tw/news/dabc757c-54d1-422e-ae88-bd2b3bd64e92

4 One Chinese tourist was arrested for vandalism and subsequently deported. See Ping-chi Laio, 'Mainland Chinese tore up the posts on the Lennon Wall in NTU campus and was deported by the Immigration Department’ 陸男台大撕毁連䀼䤧海報移民署晚間強制陸男出境, United Daily News 聯合新聞網, 8 October 2019, online at: udn.com/news/story/7321/4093919 


\section{CHAPTER 9 - Campus Conundrums: Clashes and Collaborations}

1 Leisa Scott, 'Freedom fighters', The Courier-Mail, [Brisbane], 28 September 2019.

2 Ben Packham, 'China diplomat slapped down over uni protest', The Australian, 27 June 2019, online at: www.theaustralian.com.au/nation/politics/china-diplomat-slapped-down-overuni-protest/news-story/7b0acc2e8b2b8541adc0f61e6a2e3a68

3 Australian Associated Press, 'Australia warns diplomats after China praises "patriotic” clashes with pro-Hong Kong protesters', The Guardian, 27 July 2019, online at: www.theguardian.com/ australia-news/2019/jul/27/australia-warns-diplomats-after-china-praises-patriotic-clashes-with-pro-hong-kong-protesters

4 Packham, 'China diplomat slapped down over uni protest'.

5 Fergus Hunter, 'Universities must accept China's directives on Confucius Institutes, contracts reveal', Sydney Morning Herald, 25 July 2019, online at: www.smh.com.au/politics/ federal/universities-must-accept-china-s-directives-on-confucius-institutes-contracts-reveal-20190724-p52ab9.html

6 'Professor probed on tracker', The Australian, 26 August 2019, online at: www.theaustralian.com.au/nation/politics/uq-researcher-probed-over-ai-uighur-surveil/news-story/33a6ae6b304c6363d2a4be6a22bc4887; and Alex Joske, 'The company with Aussie roots that's helping build China's surveillance state', The Strategist, 26 August 2019, online at: www. aspistrategist.org.au/the-company-with-aussie-roots-thats-helping-build-chinas-surveillance-state/

7 Joske, 'The company with Aussie roots that's helping build China's surveillance state'.

8 University of Queensland, 'UQ responds', online at: www.uq.edu.au/news/uq-responds

9 See Peter Varghese, 'Australian universities and China: We need clear-eyed engagement', The Strategist, 23 August 2019, online at: www.aspistrategist.org.au/australian-universities-and-china-we-need-clear-eyed-engagement/

${ }^{10}$ Marise Payne, 'Defence Trade Controls Act review', Media release, Canberra: Australian Government, 20 April 2018, online at: www.minister.defence.gov.au/minister/marise-payne/ media-releases/defence-trade-controls-act-review

${ }^{11}$ Department of Education, 'Establishment of a university foreign interference taskforce', News, Canberra: Australian Government, 29 August 2019, online at: www.education.gov.au/news/ establishment-university-foreign-interference-taskforce

12 The full set of guidelines is available in Department of Education, The University Foreign Interference Taskforce: Guidelines to Counter Foreign Interference in the Australian University Sector, Canberra: Australian Government, 13 November 2019, online at: www.education.gov.au/ufit

${ }^{13}$ See Kelvin K. Droegemeier, Letter to the United States Research Community, Washington, DC: Executive Office of the President, Office of Science and Technology Policy, 16 September 2019, online at: www.whitehouse.gov/wp-content/uploads/2019/09/OSTP-letter-to-the-US-research-community-september-2019.pdf

${ }^{14}$ See Dr Christopher Ashley Ford, 'Coalitions of Caution: Building a Global Coalition against Chinese Technology-Transfer Threats, Remarks by the Assistant Secretary, Bureau of International Security and Nonproliferation, FBI, Department of Commerce Conference on Counter-Intelligence and Export Control, Indianapolis, 13 September 2018', online at: www.state. gov/remarks-and-releases-bureau-of-international-security-and-nonproliferation/coalitions-of-caution-building-a-global-coalition-against-chinese-technology-transfer-threats/ 
${ }^{15}$ See Ana Swanson and Paul Mozur, 'US blacklists 28 Chinese entities over abuses in Xinjiang', The New York Times, 7 October 2019, online at: www.nytimes.com/2019/10/07/us/politics/us-toblacklist-28-chinese-entities-over-abuses-in-xinjiang.html

${ }^{16}$ See David R. Stilwell, 'Science and Technology Cooperation: Reevaluating Assumptions, Risks to Research, and a Way Forward, Remarks by the Assistant Secretary, Bureau of East Asian and Pacific Affairs, to the Committee of 100 Conference: Science and Technology Caught between the United States and China', [Delivered via Livestream], 28 September 2019, online at: www. state.gov/science-and-technology-cooperation-reevaluating-assumptions-risks-to-research-and-a-way-forward/

17 See L. Rafael Reif, 'Letter to the MIT community: Immigration is a kind of oxygen', MIT News, Cambridge, MA: Massachusetts Institute of Technology, 25 June 2019, online at: news.mit. edu/2019/letter-community-immigration-is-oxygen-0625

18 See Mara Hvistendahl, 'Spying charges against Chinese-American scientists spark fears of a witch hunt', South China Morning Post Magazine, 5 May 2018, online at: www.scmp.com/magazines/post-magazine/long-reads/article/2144652/spying-charges-against-chinese-american

${ }^{19}$ James Laurenceson and Michael Zhou, Partners in Knowledge Creation: Trends in AustraliaChina Research Collaboration and Future Challenges, Working Paper, Sydney: UTS AustraliaChina Relations Institute, 19 July 2019, online at: www.australiachinarelations.org/content/ working-paper-partners-knowledge-creation-trends-australia-china-research-collaboration-and

${ }^{20}$ Department of Industry, Innovation and Science, Collaborating with China on Science and Research, Canberra: Australian Government, 6 December 2019, online at: www.industry.gov. au/funding-and-incentives/collaborating-with-china-on-science-and-research

${ }^{21}$ See Malcolm Turnbull, 'Speech at the University of New South Wales, Sydney, 7 August 2018', online at: www.malcolmturnbull.com.au/media/speech-at-the-university-of-new-southwales-sydney-7-august-2018

22 See Michael Shoebridge, Submission to the Review of the Defence Trade Controls Act 2012, Canberra: Australian Strategic Policy Institute, 25 July 2018, online at: www.defence.gov.au/Publications/Reviews/tradecontrols/Docs/Michael Schoebridge (ASPI).pdf

${ }^{23}$ John Fitzgerald, 'Intellectual freedoms challenged by universities' uncritical embrace of China', Australian Financial Review, 7 September 2017, online at: www.afr.com/policy/health-and-education/intellectual-freedoms-challenged-by-universities-uncritical-embrace-of-china-20170904-gya1pk

${ }^{24}$ Human Rights Watch, China's Algorithms of Repression, New York: HRW, 1 May 2019, online at: www.hrw.org/report/2019/05/01/chinas-algorithms-repression/reverse-engineering-xinjiang-police-mass-surveillance

${ }^{25}$ Danielle Cave and Brendan Thomas-Noone, 'CSIRO cooperation with Chinese defence contractor should raise questions', The Guardian, 3 June 2017, online at: www.theguardian. com/australia-news/2017/jun/03/csiro-cooperation-with-chinese-defence-contractor-should-raise-questions

${ }^{26}$ Ibid.

${ }^{27}$ Sophie McNeill, Jeanavive McGregor, Meredith Griffiths, Michael Walsh, and Echo Hui, 'UTS, Curtin unis announce reviews over links to surveillance tech used by Chinese Government', Four Corners, [ABC TV], 16 July 2019, online at: www.abc.net.au/news/2019-07-16/australian-unis-to-review-links-to-chinese-surveillance-tech/11309598 
${ }^{28}$ John Power, 'China's tech rise poses security and human rights dilemma for Australian universities', South China Morning Post, 21 October 2019, online at: www.scmp.com/week-asia/ politics/article/3033604/chinas-tech-rise-poses-security-and-human-rights-dilemma

${ }^{29}$ See Foreign Affairs, Defence and Trade Legislation Committee, Estimates, Canberra: Parliament of Australia, 15 December 2017, online at: parlinfo.aph.gov.au/parlInfo/search/ display/display.w3p;query=Id:\%22committees/estimate/b6133162-5190-4a33-ab1964116b7d22a1/0000\%22

30 See Dr Vivienne Thom, Independent Review of the Defence Trade Controls Act 2012, Canberra: Commonwealth of Australia, October 2018, online at: www.defence.gov.au/publications/ reviews/tradecontrols/Docs/DTC Act Review Final Report.pdf

31 Organisation for Economic Co-operation and Devlopment (OECD), 'Gross domestic spending on R\&D', OECD Science, Technology and R\&D Statistics: Main Science and Technology Indicators, Paris: OECD, 2019, online at: data.oecd.org/rd/gross-domestic-spending-on-r-d.htm\#indicator-chart

32 'No pay, no gain: Huawei outspends Apple on R\&D for a 5G edge', Bloomberg News, 26 April 2019, online at: www.bloomberg.com/news/articles/2019-04-25/huawei-s-r-d-spending-balloonsas-u-s-tensions-flare-over-5g

${ }^{33}$ Joe Kelly, 'Ex-spy boss Dennis Richardson fears China Cold War', The Australian, 10 June 2019.

${ }^{34}$ Peter Varghese, 'Australia, the United States and the Indo-Pacific: Keynote Address', Sydney: United States Studies Centre, 21 August 2019, online at: www.ussc.edu.au/analysis/australia-the-united-states-and-the-indo-pacific-keynote-address-delivered-by-peter-varghese-ao 



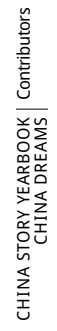




\section{ONTRIBUTORS}

Beyongo Mukete Dynamic is an associate editor for the National Times News, an online newspaper based in Cameroon, and research officer at the Australian Centre on China in the World (CIW), The Australian National University (ANU). Beyongo's research interests include international political economy, BRICS, Africa's political economy, geo-economics, Australia's foreign policy, and political philosophy.

Jane Brophy is a medical sociologist and currently the postdoctoral research fellow in public policy and regulation at the University of Melbourne's School of Government. Her research focuses on the social and regulatory dimensions associated with new and emerging biotechnologies (such as stem cell treatments and genetic editing) in a global context, with a special interest in China.

Lennon Yao-Chung Chang is a Senior Lecturer in Criminology at Monash University. He has been working on cybercrime and the governance of cyberspace in the Greater China Region for more than 15 years with a focus on misinformation, coproduction of cyber security and internet vigilantism.

Jingjing Chen is a $\mathrm{PhD}$ candidate at the School of Culture, History and Language at the ANU. Her doctoral research focuses on Tang dynasty religious and geographical history.

Antony Dapiran is a Hong Kong-based writer and lawyer, and the author of two books on Hong Kong including his 
latest, City on Fire: The Fight for Hong Kong (Scribe, 2020). He has written and presented extensively on Hong Kong and Chinese politics, culture and business, with his writing appearing in The Atlantic, New Statesman, Foreign Policy, Art Asia Pacific, Mekong Review and The Guardian, among many others. Antony has resided between Hong Kong and Beijing for over twenty years.

Gloria Davies is a literary scholar and historian of China. She is Professor of Chinese Studies in the School of Languages, Literatures, Cultures and Linguistics at Monash University.

Victor Ferguson is a $\mathrm{PhD}$ Candidate in the ANU School of Politics and International Relations. His research focuses on the intersection of economic statecraft, international trade and investment law, and international security.

Victor Fong is a PhD candidate at the School of Culture, History and Language at the ANU. His doctoral research focuses on Chinese imperial law, ethnic relations and identity.

Jane Golley is an economist focused on a range of Chinese transition and development issues. She is the Director of the Australian Centre on China in the World (CIW).

Gerry Groot is Senior Lecturer in Chinese Studies in the Department of Asian Studies at the University of Adelaide. He researches the roles of the Chinese Communist Party's United Front at home and abroad, Chinese conspiracy theories, soft power, ghosts, and cookbooks.

Paul Harris is Director of the Australian National University's North American Liaison Office based in Washington DC. Prior to this position he worked in the Australian Embassy in Tokyo as Counsellor (Education and Science). He has also worked at ANU in the Crawford School of Public Policy as Deputy Director of the HC Coombs Policy Forum and Program Leader of the Science, Technology and Public Policy program, at CSIRO as General Manager of Government and International Relations and in the Australian Government as Acting General Manager, Science Policy in the Department of Innovation, Industry, Science, Research and Tertiary Education. 
Ben Hillman is a political scientist, public policy researcher, and advisor at the Crawford School of Public Policy, ANU. His research examines policies and mechanisms for promoting political inclusion and safeguarding minority rights.

Chiung-Chiu Huang is an Associate Professor in the Graduate Institute of East Asian Studies at National Chengchi University. Her research focus includes Chinese foreign policy, Southeast Asian international politics and SinoMongolia relations. She published the book Harmonious Intervention: China's Quest for Relational Security in 2014.

Linda Jaivin is the author of eleven books - including the China memoir The Monkey and the Dragon - an essayist, translator, co-editor with Geremie R. Barmé of the anthology of translation New Ghosts Old Dreams: Chinese Rebel Voices, and editorial consultant at the Australian Centre on China in the World, ANU. She is currently working on The Shortest History of China, due out with Black Inc towards the end of 2020.

Hyung-geun Kim is an associate professor of Chinese studies at Silla
University, Busan, South Korea, where he teaches Chinese economics and trade. He was a Visiting Fellow at the Australian Centre on China in the World in 2019. Since 2014, he has been a member of the Editorial Board of the Journal of China Area Studies (Korea Citation Index). His current research interests include China's Belt and Road Initiative, contemporary Sino-Korean economics, and Chinese consumer markets.

Esther Sunkyung Klein is a lecturer in pre-modern Chinese studies at the University of Sydney, focusing on issues in Chinese thought and historiography. Her book, Reading Sima Qian from Han to Song (2019), traces pre-modern Chinese views of the historian as author.

James Laurenceson is the director of the Australia-China Relations Institute at the University of Technology Sydney. His research focuses on the Chinese economy and the AustraliaChina bilateral relationship.

James Leibold is the Head of the Politics, Media and Philosophy Department at La Trobe University. His research focuses on the politics of 
ethnicity, race and national identity in modern Chinese history and society, and he is currently engaged in research on ethnic policy-making and governance in contemporary China with a particular focus on the Western frontier and its Tibetan and Uyghur ethnic minorities.

Darren Lim is a Senior Lecturer in the ANU College of Arts and Social Sciences and host of the 'Australia in the World' podcast. He researches in the fields of international political economy and international security, with a focus on geoeconomics.

Louisa Lim teaches audiovisual journalism at the Centre for Advancing Journalism at The University of Melbourne. A former BBC and NPR correspondent, she is the author of The People's Republic of Amnesia and co-hosts the Little Red Podcast.

Adam Ni is the co-editor of China Neican, a policy newsletter on China issues, and a China researcher affiliated with the Macquarie University in Sydney. His focus includes China's international relations, strategy and security issues.

Uchralt Otede is a $\mathrm{PhD}$ Candidate in the ANU College of Asia and the Pacific.
His research focus on Informal Life Politics in China and Mongolia.

Samuel J. Parsons is currently completing a Bachelor of Arts at the University of Adelaide. His interests include political philosophy and the impact of ideas on social and political organisation. He will undertake an honours in philosophy in 2020.

Benjamin Penny is an historian of religions in China at the School of Culture, History and Language, ANU. He is the editor of East Asian History.

Annie Luman Ren is a PhD candidate at the School of Culture, History, and Language. She is currently writing her doctoral thesis on the poetics of the mid-Qing novel Hongloumeng 紅 樓夢 (known to English readers as The Story of the Stone or The Dream of the Red Chamber). She is also working with Professor John Minford on a reader's companion to this towering masterpiece of Chinese fiction.

Gerald Roche is an anthropologist and Senior Research Fellow in the Department of Politics, Media, and Philosophy at La Trobe University. His research focuses on language politics in Tibet, China, and the transnational Himalaya. 
Richard Rigby is an Emeritus Professor in the ANU College of Asia and the Pacific. He has a Ph.D in modern Chinese history from the ANU. Most of his professional life was spent as a diplomat (including three China postings, amongst others), and senior intelligence analyst. From 2008-2018 he worked as Founding Director of the ANU China Institute, and concurrently for most of this period as Associate Director of the Australian Centre on China in the World, ANU. His interests include late-Qing and Republican history, contemporary Chinese thought and politics, including foreign policy.

Olivia Shen was a 2019 Fulbright Professional Scholar and visiting fellow at the Center for Strategic Studies where her research focused on the ethical uses of artificial intelligence. She has been a policy adviser to the Australian Government for over ten years. In 2018, Olivia won the ANU's Master of Public Policy Prize.

Graeme Smith is a fellow in the Department of Pacific Affairs at The Australian National University, and co-hosts the Little Red Podcast with Louisa Lim. Graeme's research focuses on PRC state and corporate actors in the South Pacific, the motivations of local officials in rural Anhui, and the political incentives of China's tech companies in Southeast Asia and Australia.

Brendan Taylor is Professor of Strategic Studies at The Australian National University. He is the author or editor of 12 books, including The Four Flashpoints: How Asia Goes to War (Black Inc, 2018) and Dangerous Decade: Taiwan's Security and Crisis Management (IISS, 2019).

Jamie J. Zhao is an Assistant Professor of Communications in the Department of Media and Communication at Xi'an Jiaotong-Liverpool University. She holds a PhD in Gender Studies from the Chinese University of Hong Kong and has completed another PhD in Film and TV Studies from the University of Warwick. Her research explores East Asian media and public discourses on gender and sexuality in a globalist age. She is also the co-editor of and contributor to the anthology, Boys' Love, Cosplay, and Androgynous Idols: Queer Fan Cultures in Mainland China, Hong Kong, and Taiwan (HKUP, 2017). 


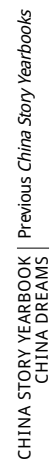




\section{PREVIOUS CHINA STORY
YEARBOOKS}

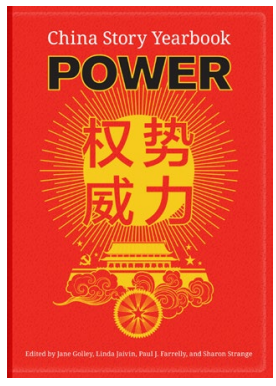

\section{8: Power}

In 2018, the People's Republic of China (PRC) was, by most measures, more powerful than at any other time in its history and had become one of the most powerful countries in the world. Its economy faced serious challenges, including from the ongoing 'trade war' with the US, but still ranked as the world's second largest. Its Belt and Road Initiative, meanwhile, continued to carve paths of influence and economic integration across several continents. A deft combination of policy, investment, and entrepreneurship has also turned the PRC into a global 'techno-power'. It aims, with a good chance of success, at becoming a global science and technology leader by 2049 - one hundred years from the founding of the PRC.

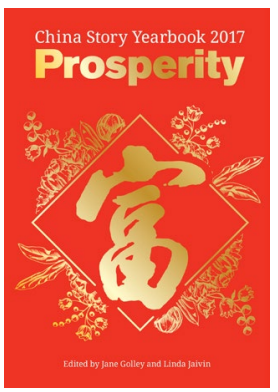

\section{7: Prosperity}

A 'moderately prosperous society' with no Chinese individual left behind - that's the vision for China set out by Chinese President Xi Jinping in a number of important speeches in 2017. 'Moderate' prosperity may seem like a modest goal for a country with more billionaires (609 at last count) than the US. But the 'China Story' is a complex one. The China Story Yearbook 2017: Prosperity surveys the important events, pronouncements, and personalitites that defined 2017. It also presents a range of perspectives, from the global to the individual, the official to the unofficial, from mainland China to Hong Kong and Taiwan. Together, the stories present a richly textured portrait of a nation that in just forty years has lifted itself from universal poverty to (unequally distributed) wealth, changing itself and the world in the process. 

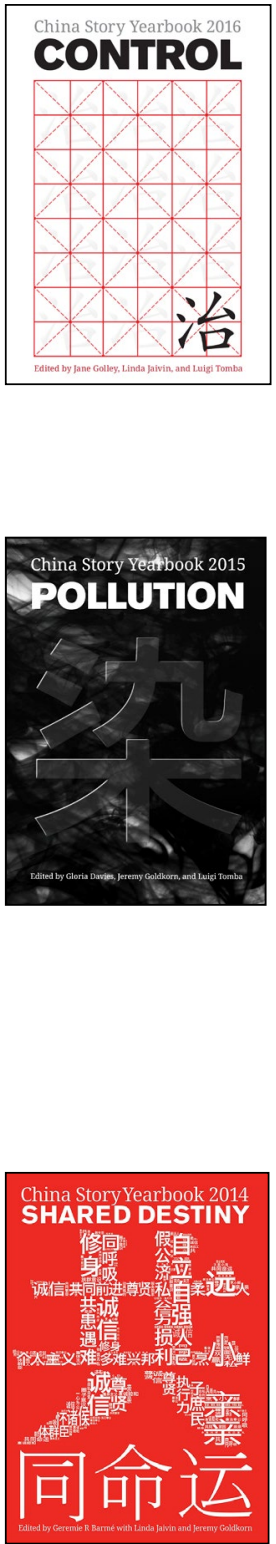

\section{6: Control}

'More cosmopolitan, more lively, more global' is how the China Daily summed up the year 2016 in China.

It was also a year of more control. The Chinese Communist Party laid down strict new rules of conduct for its members, continued to assert its dominance over everything from the Internet to the South China Sea and announced a new Five-Year Plan that Greenpeace called 'quite possibly the most important document in the world in setting the pace of acting on climate change'.

\section{5: Pollution}

This Yearbook explores the broader ramifications of pollution in the People's Republic for culture, society law and social activism, as well as the Internet, language, thought, and approaches to history. It looks at how it affects economic and political developments, urban change, and China's regional and global posture. The Chinese Communist Party, led by 'Chairman of Everything' $\mathrm{Xi}$ Jinping, meanwhile, has subjected mainland society to increasingly repressive control in its new determination to rid the country of Western 'spiritual pollutants' while achieving cultural purification through 'propaganda and ideological work'.

\section{4: Shared Destiny}

The People's Republic of China under the leadership of the Chinese Communist Party and Xi Jinping, has declared that it shares in the destiny of the countries of the Asia and Pacific region, as well as of nations that are part of an intertwined national self-interest. The China Story Yearbook 2014 takes the theme of Shared Destiny 共同命运 and considers it in the context of China's current and future potential. 

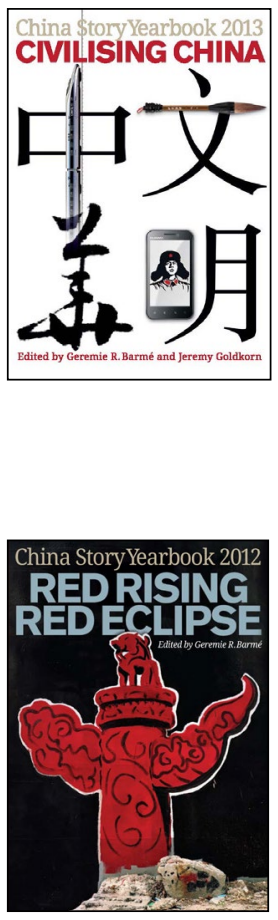

\section{3: Civilising China}

As China becomes wealthier and more confident on the global stage, it also expects to be respected and accommodated as a major global force - and as a formidable civilisation. Through a survey and analysis of China's regional posture, urban change, social activism and law, mores, the Internet, history, and thought - in which the concept of 'civilising' plays a prominent role - China Story Yearbook 2013 offers insights into the country today and its dreams for the future.

\section{2: Red Rising, Red Eclipse}

The authors of Red Rising, Red Eclipse survey China's regional posture, urban change, social activism and law, human rights and economics, the Internet, history, and thought. This inaugural China Story Yearbook offers an informed perspective on recent developments in China and provides a context for understanding ongoing issues that will resonate far beyond the Dragon Year of 2012-2013 
